\title{
AN INVESTIGATION INTO THE ABSENCE OF MUSSELS (Perna canaliculus, Aulacomya maoriana and Mytilus galloprovincialis) FROM THE SOUTH COAST OF WELLINGTON, \\ NEW ZEALAND
}

\author{
Jeremy G Helson
}

2001

This thesis is submitted in total fulfilment of the requirements of the degree of Doctor of Philosophy in Zoology

Victoria University of Wellington

New Zealand 


\section{Acknowledgments}

Although my name appears on the cover of this work, many people have assisted in its completion. My supervisor, Dr Jonathan Gardner from day one has provided me with expert assistance in all facets, both practical and theoretical. He was always available for advice and discussion on any detail of this work and I would not hesitate to recommend him as a supervisor to any prospective student. I am also indebted to Drs Edith Hodgen and Shirley Pledger who helped negotiate the statistical minefield. Thanks also go to Dr Elizabeth MacAvoy who helped with biochemical analyses and Drs Karyne Rogers and Graeme Lyon of the Institute of Geological and Nuclear Sciences who carried out the C:N analysis of water samples.

Island Bay Marine Laboratory technician, Robert Williamson, was exceptionally helpful in the collection of field samples aboard the $R V$ Raukawa Challenger. Not only did he provide field assistance as skipper of the vessel, but also assisted in diving support and instruction in the use of the Raukawa Challenger. His unfaltering enthusiasm and willingness to make himself available at weekends and at all times of the day and night was greatly appreciated. Robert's vast array of skills was utilised for preparation and deployment of field equipment on many occasions, and construction of the occasional coffee table and other miscellaneous items.

Thanks also to Paul Gribben of Auckland University who served as a sounding board for new ideas and as a source of information and motivation. Not to mention a drinking partner at NZMSS conferences (amongst other occasions), inventor of the now infamous screaming lizard, and golfing partner on his frequent visits to Wellington.

I would also like to thank my mother, Sheryl, and Richard, both of whom provided support, financial assistance and plenty of encouragement.

Finally, but most importantly I thank my wife, Rachel, who has experienced the highs and lows of PhD life vicariously over the past few years. She has been a great source of moral support and also provided technical assistance in numerous aspects of computing. In addition to this, she didn't even complain when put to work at the weekends as data recorder, field or laboratory assistant. For bearing the vast majority of financial expenses during the last few years she is the 2001 recipient of an award which I believe is fast gathering international recognition, the PhT, (Putting hubby Through). 


\section{Abstract}

This thesis investigates the reason(s) for an anomalous distribution of mussels on Wellington's South Coast. Wellington Harbour supports large populations the mussels (Perna canaliculus, Aulacomya maoriana and Mytilus galloprovincialis) however; all these species are absent from the nearby South Coast. The physical difference between Harbour and Coastal sites was confirmed from water samples taken at eight sites inside and outside Wellington Harbour between September 1998 and February 2000. These data showed significant differences between Harbour and Coastal sites in seven of eleven parameters tested. Larval densities were investigated at Harbour and Coastal sites; data showed larval density to be approximately an order of magnitude greater in Harbour waters compared to the Coast. Larval density in Coastal waters reached a maximum of $380 \mathrm{~m}^{-3}$ and is therefore not expected to be a major limiting factor. Similar results were found for studies of settlement density on artificial substrates. Settlement at Harbour sites was approximately 10 times that at Coastal sites, however, mussel densities of up to $\approx 3700 \mathrm{~m}^{-2}$ at Coastal sites indicate that settlement is also unlikely to be a factor contributing to mussel absence.

Comparisons were made of body condition index between Harbour mussels and those from the Harbour relocated to the Island Bay Marine Laboratory (IBML) on Wellington's South Coast. All mussel species experienced a significant decrease in condition at IBML when compared with those from the parent population in Wellington Harbour. Levels of mortality were high in P. canaliculus (60\%) and $M$. galloprovincialis (70\%) and moderate in A. maoriana (30\%). This indicated the possibility of nutrient limitation as a cause of mussel absence. This was corroborated by a similar study using RNA:DNA ratio as a biochemical index of condition. Mussels held at IBML experienced a significant decrease in RNA:DNA compared to those from the parent population within the Harbour.

Further investigation of nutrient limitation was conducted by way of feeding experiments to estimate the scope for growth (SFG) of each mussel species. In $P$. canaliculus, SFG had a mean $( \pm \mathrm{SD})$ of $45.6 \mathrm{~J} \mathrm{~g}^{-1} \mathrm{~h}^{-1}( \pm 78.9)$ and only $27 \%$ of observations were negative. A. maoriana had lower SFG estimates, mean SFG was $19.1 \mathrm{~J} \mathrm{~g}^{-1} \mathrm{~h}^{-1}( \pm 66.7)$ and negative SFG was recorded $43 \%$ of the time. $M$. 
galloprovincialis had mean SFG of $1.26 \mathrm{~J} \mathrm{~g}^{-1} \mathrm{~h}^{-1}$ ( \pm 39.1$)$, 52\% of SFG estimates were negative. While these data do not overwhelming support the hypothesis of nutrient limitation, they do go some way toward corroborating the findings of the condition index experiments.

Models to predict SFG were derived from data in the feeding experiments, these models were derived from a small range of low seston concentrations. A second group of models was derived from studies conducted by Gardner (2001) to give a broader range of seston concentrations. Seston data from the water sampling described above were used to estimate SFG at eight sites inside and outside the Harbour over the period from September 1998 to February 2000. Both models estimated lower SFG at Coastal sites compared to Harbour sites. However, estimates were not consistently negative at Coastal sites. These models had mixed results and would benefit from the combination of data from recent SFG experiments conducted at IBML and Wellington Harbour to derive new, more robust models.

While the findings in this study are not conclusive, the absence of mussels from Wellington's South Coast is most likely to be the result of nutrient limitation for at least part of the year. The reduced ability of mussels to store nutrients when feeding on Cook Strait water is likely to exacerbate the effects of low seston quality. 


\section{Contents}

\section{CHAPTER ONE}

An Investigation into Mussel absence from the South Coast of Wellington, New Zealand ......................... 1

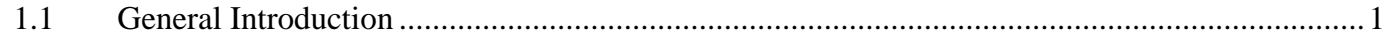

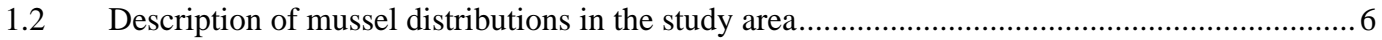

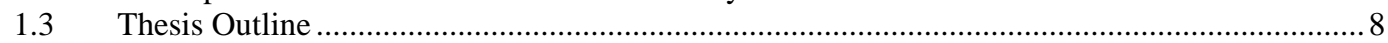

\section{CHAPTER TWO}

Characteristics of Water Samples at Harbour and Coastal Sites............................................................. 11

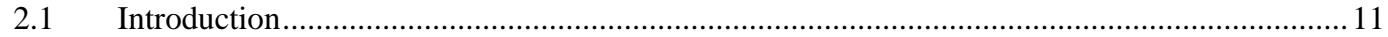

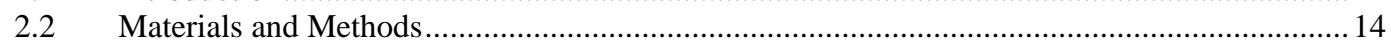

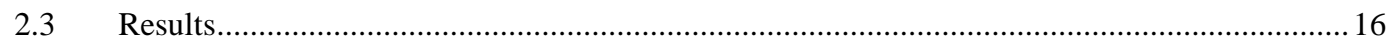

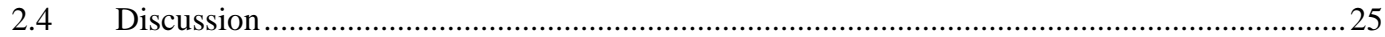

\section{CHAPTER THREE}

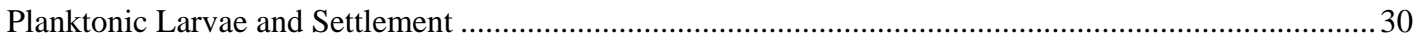

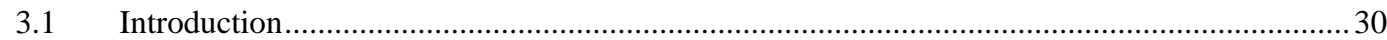

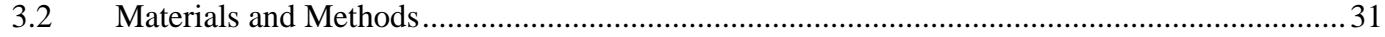

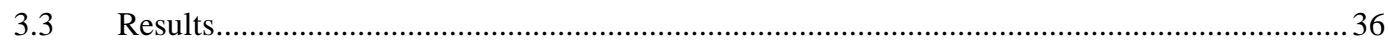

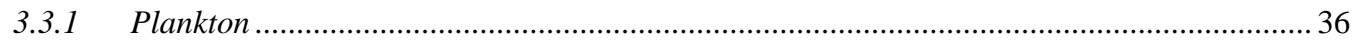

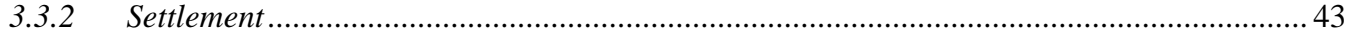

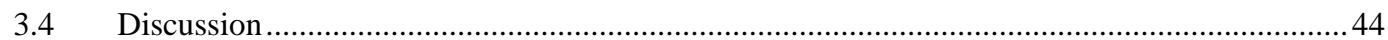

CHAPTER FOUR

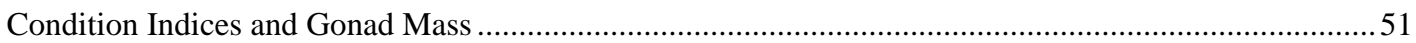

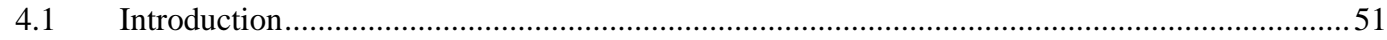

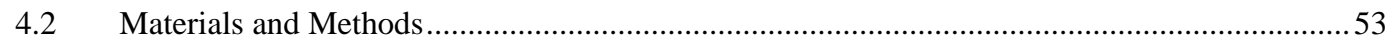

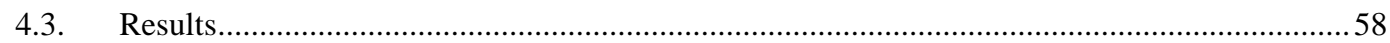

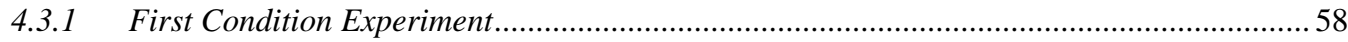

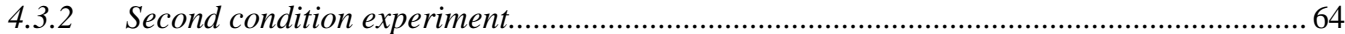

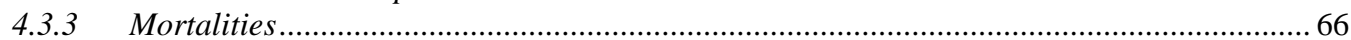

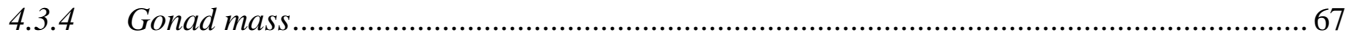

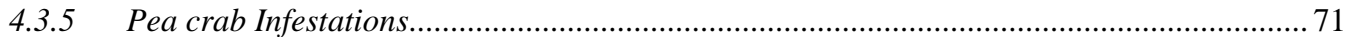

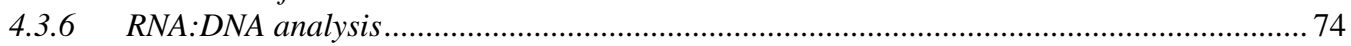

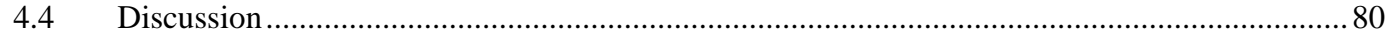

CHAPTER FIVE

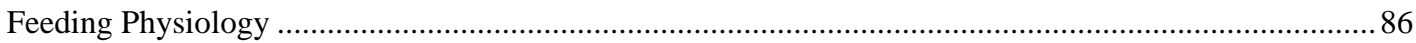

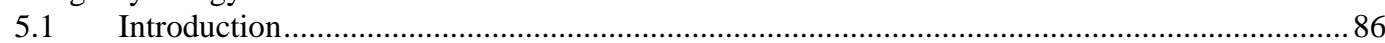

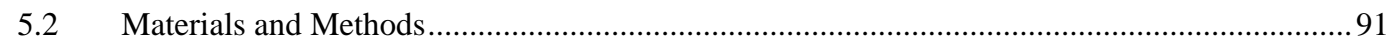

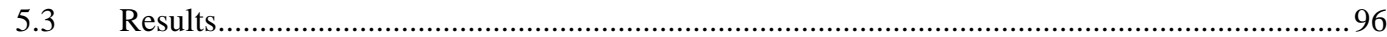

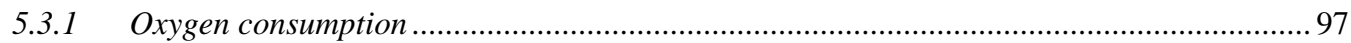

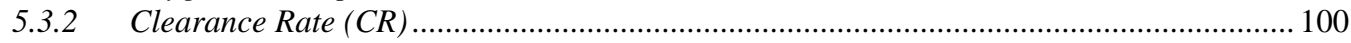

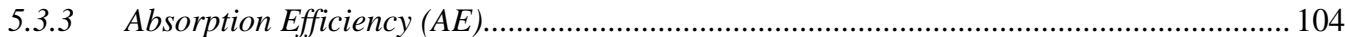

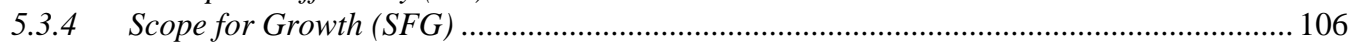

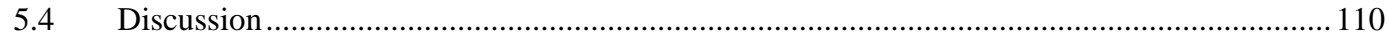

CHAPTER SIX

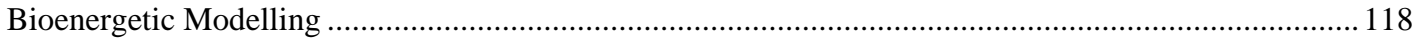

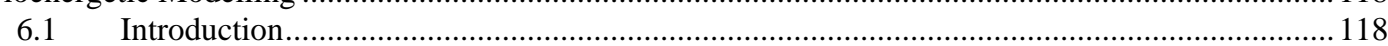

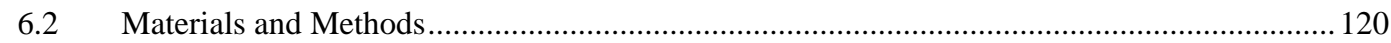

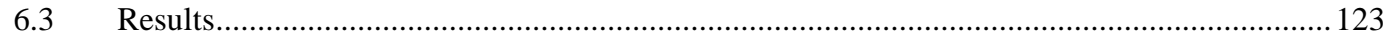

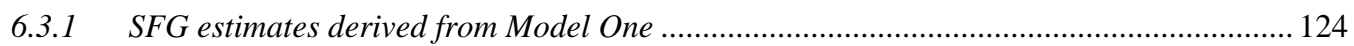

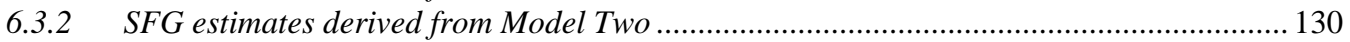

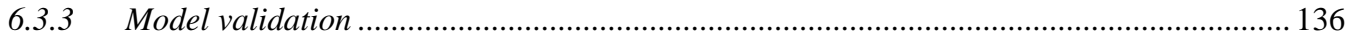

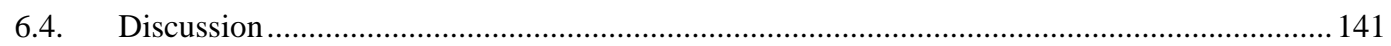

CHAPTER SEVEN

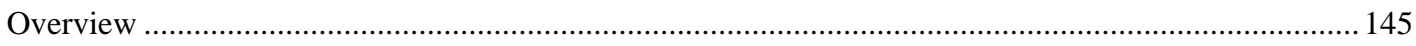

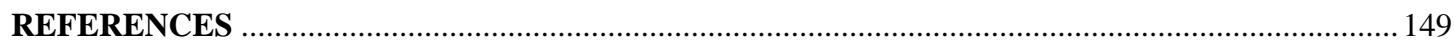

APPENDIX A

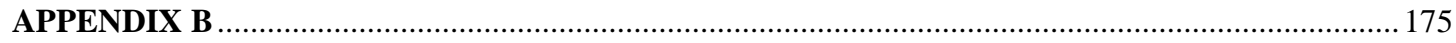




\section{List of Figures}

\section{CHAPTER ONE}

Figure 1.1. Map of Harbour and Coastal area showing 'transition zone' ..................................... 2

Figure 1.2. Flow diagram showing the initial design of the study ........................................... 4

Figure 1.3. Map of general currents in Cook Strait and Wellington Harbour.................................. 6

Figure 1.4. Mussel distribution at 'transition zone' .............................................................. 8

\section{CHAPTER TWO}

Figure 2.1. Map of sites where water samples were collected 13

Figure 2.2. Mean seasonal variation in water temperature at all sites ............................................. 16

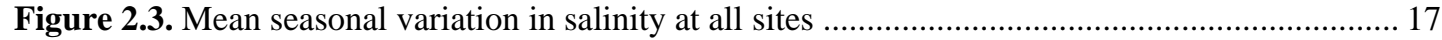

Figure 2.4. Mean seasonal variation in dissolved oxygen at all sites ............................................. 17

Figure 2.5. Mean seasonal variation in total particulate matter (TPM) at all sites ............................ 18

Figure 2.6. Mean seasonal variation in particulate organic matter (POM) ..................................... 19

Figure 2.7. Mean seasonal variation in percent organic matter (PCOM) ....................................... 20

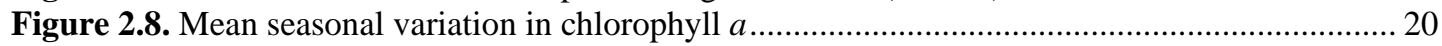

Figure 2.9. Mean seasonal variation in particle counts $(2.5-63.0 \mu \mathrm{m})$............................................ 21

Figure 2.10. Mean seasonal variation in ratio of carbon to nitrogen ............................................. 21

Figure 2.11. Mean seasonal variation in percent carbon........................................................... 22

Figure 2.12. Mean seasonal variation in percent nitrogen ....................................................... 23

\section{CHAPTER THREE}

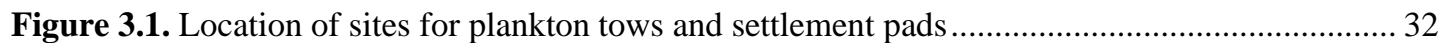

Figure 3.2. Mussel larval density at all sites on a logarithmic scale - all species .............................. 37

Figure 3.3. Mussel larval density at the three study sites - separate species................................... 38

Figure 3.4. Mussel larval plankton density and temperature at all sites ........................................ 39

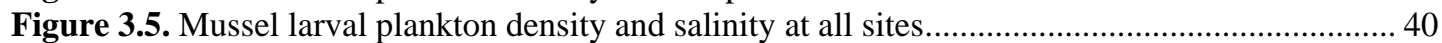

Figure 3.6. Number of mussels per settlement pad at Harbour sites................................................ 43

Figure 3.7. Number of mussels per settlement pad at Coastal sites ................................................ 44

\section{CHAPTER FOUR}

Figure 4.1. Map of mussels collection sites for condition experiments ......................................... 53

Figure 4.2. Flow chart showing procedure for the extraction of RNA and DNA from mussels..........57

Figure 4.3. Condition indices for all three species from Harbour and IBML population .................... 60

Figure 4.4. Body condition at Harbour site and water temperature in all species............................... 63

Figure 4.5. Body condition at Harbour site and chlorophyll $a$ in all species .................................. 64

Figure 4.6. Second condition experiment - Harbour and IBML mussles, all species ........................ 65

Figure 4.7. Mortalities of mussels held at IBML during both condition experiments ....................... 67

Figure 4.8. Gonad mass in P. canaliculus in Harbour and IBML mussles ...................................... 68

Figure 4.9. Gonad mass in A. maoriana in Harbour and IBML mussels..........................................69

Figure 4.10. Gonad mass in M. galloprovincialis in Harbour and IBML mussels ........................... 70

Figure 4.11. DNA, RNA and RNA:DNA ratio for all species from Kau Bay and IBML ................. 75

\section{CHAPTER FIVE}

Figure 5.1. Low temperature and high temperature oxygen consumption rates - all species ............. 98 Figure 5.2. Oxygen consumption rate in all three mussel species held at IBML for ten weeks .......... 99 


\section{CHAPTER SIX}

Figure 6.1. Model One: Mean estimated SFG for $P$. canaliculus.................................................. 125

Figure 6.2. Model One: Temporal variation in estimated SFG at all sites for $P$. canaliculus ........... 125

Figure 6.2. (Cont.) Model One: Temporal variation in SFG at all sites for P. canaliculus ............... 126

Figure 6.3. Model One: Mean estimated SFG for A. maoriana ...................................................... 127

Figure 6.4. Model One: Temporal variation in estimated SFG at all sites for A.maoriana ............... 127

Figure 6.4. (Cont.) Model One: Temporal variation in SFG at all sites for A. maoriana .................. 128

Figure 6.5. Model One: Mean estimated SFG for M. galloprovincialis ....................................... 128

Figure 6.6. Model One: Temporal variation in SFG at all sites for M. galloprovincialis................. 129

Figure 6.6. (Cont.) Model One: Temporal variation in SFG at all sites for M. galloprovincialis...... 130

Figure 6.7. Model Two: Mean estimated SFG for P. canaliculus ................................................. 131

Figure 6.8. Model Two: Temporal variation in estimated SFG at all sites for $P$. canaliculus........... 132

Figure 6.9. Model Two: Mean estimated SFG A. maoriana.......................................................... 133

Figure 6.10. Model Two: Temporal variation in estimated SFG at all sites for A. maoriana........... 134

Figure 6.11. Model Two: Mean estimated SFG for M. galloprovincialis ..................................... 135

Figure 6.12. Model Two: Temporal variation in SFG at all sites for M. galloprovincialis ............... 136

Figure 6.13. Model One validation: Experimental and modelled SFG for $P$. canaliculus ................ 137

Figure 6.14. Model Two validation: Experimental and modelled SFG for $P$. canaliculus............... 138

Figure 6.15. Model One validation: Experimental and modelled SFG for A. maoriana .................. 139

Figure 6.16. Model Two validation: Experimental and modelled SFG for A. maoriana.................. 139

Figure 6.17. Model One validation: Experimental and modelled SFG for M. galloprovincialis....... 140

Figure 6.18. Model Two validation: Experimental and modelled SFG for M. galloprovincialis ...... 140

\section{APPENDIX A}

Appendix A1. Water temperature at all sites and seasons .......................................................... 164

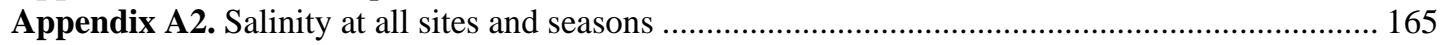

Appendix A3. Dissolved Oxygen at all sites and seasons ........................................................ 166

Appendix A4. Total particulate matter (TPM) at all sites and seasons......................................... 167

Appendix A5. Particulate organic matter (POM) at all sites and seasons...................................... 168

Appendix A6. Percent organic matter at all sites in all seasons................................................... 169

Appendix A7. Chlorophyll $a$ concentration at all sites and seasons ............................................ 170

Appendix A8. Particle count (2.5-63.0 $\left.\mu \mathrm{m} \mathrm{ml}^{-1}\right)$ at all sites and seasons ......................................... 171

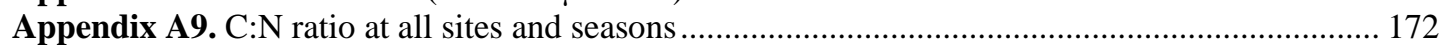

Appendix A10. Percent Carbon at all sites and seasons .............................................................. 173

Appendix A11. Percent Nitrogen at all sites and seasons........................................................ 174

\section{APPENDIX B}

Appendix B1. Clearance rate and seston characteristics for $P$. canaliculus .................................. 175

Appendix B2. Clearance rate and seston characteristics for A. maoriana ...................................... 176

Appendix B3. Clearance rate and seston characteristics for M. galloprovincialis............................ 177

Appendix B4. Absorption efficiency and seston characteristics for P. canaliculus ......................... 178

Appendix B5. Absorption efficiency and seston characteristics for A. maoriana ........................... 179

Appendix B6. Absorption efficiency and seston characteristics for M. galloprovincialis................. 180

Appendix B7. Scope for growth and seston characteristics for $P$. canaliculus................................ 181

Appendix B8. Scope for growth and seston characteristics for A. maoriana ................................. 182

Appendix B9. Scope for growth and seston characteristics for M. galloprovincialis....................... 183 


\section{List of Tables}

\section{CHAPTER TWO}

Table 2.1. Description Harbour and Coastal sampling sites ...................................................... 12

Table 2.2. Mean of temperature, salinity, dissolved oxygen, TPM and POM ................................ 19

Table 2.3. Mean of PCOM, chloropyhll $a$, particle count, C:N ratio, percent $\mathrm{C}$ and percent $\mathrm{N}$.......... 23

Table 2.4. Mutlivariate and univariate ANOVA testing among ungrouped and grouped sites........... 24

Table 2.5. Mutlivariate and univariate ANOVA testing among sampling times .............................. 24

Table 2.6. Kruskal-Wallis tests for ungrouped and grouped data ................................................ 25

\section{CHAPTER THREE}

Table 3.1. Density of mussel larvae from Harbour and Coastal sites ............................................... 36

Table 3.2. ANOVA testing for differences in larval density among sites and months ....................... 37

Table 3.3. ANOVA of density of mussel larvae including temperature and salinity .......................... 39

Table 3.4. ANOVA of mussel larvae including temperature and salinity - combined sites................ 41

Table 3.5. Pairwise comparisons of larval density among months at Kau Bay ............................... 41

Table 3.6. Pairwise comparisons of larval density among months at Island Bay ............................. 42

Table 3.7. Pairwise comparisons of larval density among months at Oteranga Bay .......................... 42

Table 3.8. Summary table of results from pairwise comparisons ................................................... 42

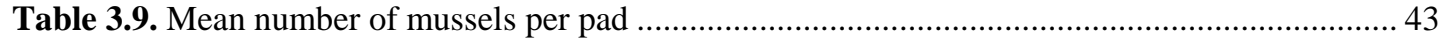

Table 3.10. ANOVA of settlement data with separate sites............................................................. 44

Table 3.11. ANOVA of settlement data with sites combined ......................................................... 44

\section{CHAPTER FOUR}

Table 4.1. Mean condition index of Harbour and IBML mussels.................................................. 59

Table 4.2. Water characteristics from Island Bay during condition index experiments...................... 61

Table 4.3. Water characteristics from Inner Dorset during condition index experiments................... 61

Table 4.4. Correlations between condition index and water characteristics at Harbour site................ 62

Table 4.5. Correlations between condition index and water characteristics at IBML.........................62 62

Table 4.6. Mean gonad mass and mean SD and CV between Harbour and IBML ........................... 70

Table 4.7. Mass and carapace width of pea crabs ...................................................................... 72

Table 4.8. Condition Index of mussel species with and without pea crabs from the Harbour............. 72

Table 4.9. Condition Index of mussel species with and without pea crabs from IBML ..................... 73

Table 4.10. Comparison of pea crab infestation rates from various studies..................................... 74

Table 4.11. RNA, DNA and RNA:DNA ratio of mussels from Kau Bay and IBML ....................... 76

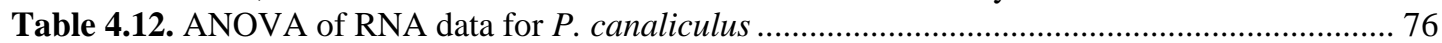

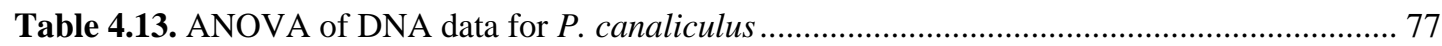

Table 4.14. ANOVA of RNA:DNA ratio data for $P$. canaliculus .................................................. 77

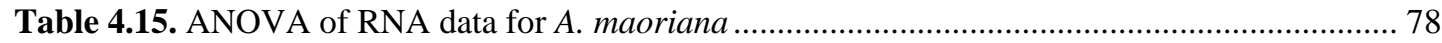

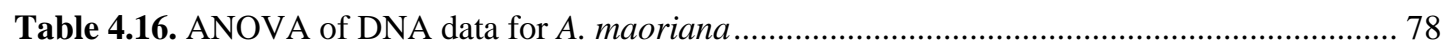

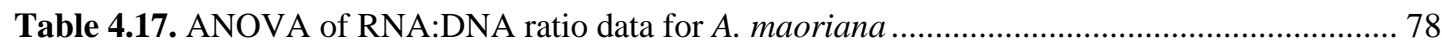

Table 4.18. ANOVA of RNA data for $M$. galloprovincialis........................................................ 78

Table 4.19. ANOVA of DNA data for $M$. galloprovincialis ........................................................ 79

Table 4.20. ANOVA of RNA:DNA ratio data for M. galloprovincialis............................................ 79

Table 4.21. ANOVA testing differences in RNA, DNA and RNA:DNA between Day

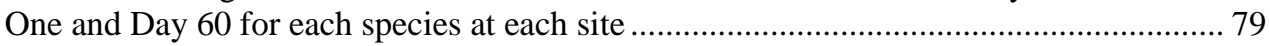

Table 4.22. Size of mussels and ANOVA of shell length between for all species in RNA:DNA experiments

\section{CHAPTER FIVE}

Table 5.1. Seston characteristics in feeding experiments.......................................................... 96

Table 5.2. Low temperature oxygen consumption data for 15 mussels of each species ..................... 97

Table 5.3. High temperature oxygen consumption data for 6 mussels of each species ..................... 97

Table 5.4. Oxygen consumption data for mussels held at IBML for an extended period................... 99

Table 5.5. Published estimates of oxygen consumption rates .................................................... 100

Table 5.6. Mean corrected clearance rate, absorption efficiency and seston characteristics for $P$. canaliculus feeding experiments...

Table 5.7. Correlations between clearance rate seston variables for $P$. canaliculus ......................... 101 
Table 5.8. Multiple regression analysis of clearance rate and seston data for $P$. canaliculus. 101

Table 5.9. Mean corrected clearance rate, absorption efficiency and seston characteristics for A. maoriana feeding experiments.

Table 5.10. Correlations between clearance rate and variables for $A$. maoriana ............................... 102

Table 5.11. Multiple regression analysis of clearance rate and seston variables for $A$. maoriana ..... 103

Table 5.12. Mean corrected clearance rate, absorption efficiency and seston characteristics for M. galloprovincialis feeding experiments....

Table 5.13. Correlations between clearance rate and variables for M. galloprovincialis ................. 103

Table 5.14. Multiple regression analysis of clearance rate and seston for M. galloprovincialis........ 104

Table 5.15. Correlations between AE and seston variables for $P$. canaliculus................................ 104

Table 5.16. Multiple regression analysis of AE and seston for $P$. canaliculus ................................. 105

Table 5.17. Correlations between AE and seston variables for A. maoriana .................................... 105

Table 5.18. Regression analysis results on AE and seston for A. maoriana ..................................... 105

Table 5.19. Correlations between AE and seston variables for M. galloprovincialis ....................... 106

Table 5.20. Regression analysis results on AE for M. galloprovincialis ....................................... 106

Table 5.21. Components of the energy budget and scope for growth for $P$. canaliculus.................. 107

Table 5.22. Correlation between SFG and seston for $P$. canaliculus............................................. 107

Table 5.23. Regression analysis results on Scope for growth $P$. canaliculus .................................. 108

Table 5.24. Components of the energy budget and scope for growth for A. maoriana .................... 108

Table 5.25. Correlations between SFG and variables for $A$. maoriana......................................... 109

Table 5.26. Regression results on scope for growth for A. maoriana ........................................... 109

Table 5.27. Components of the energy budget and scope for growth for M. galloprovincialis......... 110

Table 5.28. Correlation between SFG and individual seston variables for M. galloprovincialis....... 110

Table 5.29. Regression results of scope for growth $M$. galloprovincialis..................................... 110

\section{CHAPTER SIX}

Table 6.1. Seston from feeding experiments at IBML for each species... 121

Table 6.2. Seston from feeding experiments at IBML and Kau Bay from Gardner (2000)............... 121

Table 6.3. Hypothetical example of enrichment of ingested seston by pseudofaecal production...... 122

Table 6.4. Summary of pseudofaecal production from feeding experiments at IBML .................... 124

Table 6.5. Model One: Predicted SFG for $P$. canaliculus................................................................ 124

Table 6.6. Model One: Predicted SFG for A. maoriana .............................................................. 126

Table 6.7. Model One: Predicted SFG for M. galloprovincialis .................................................... 129

Table 6.8. Model Two: Predicted SFG for $P$. canaliculus.............................................................. 131

Table 6.9. Model Two: Predicted SFG for A. maoriana ................................................................... 133

Table 6.10. Model Two: Predicted SFG for M. galloprovincialis .................................................. 135

Table 6.11. Model validation: Comparison of SFG estimates from experimental data and Models One and Two for $P$. canaliculus ................................................................. 137

Table 6.12. Model validation: Comparison of SFG estimates from experimental data and Models One and Two for A. maoriana....

Table 6.13. Model validation: Comparison of SFG estimates from experimental data and Models One and Two for M. galloprovincialis. 


\section{CHAPTER ONE}

\section{An Investigation into Mussel absence from the South Coast of Wellington, New Zealand}

\subsection{General Introduction}

Temperate rocky shores are characterised by zones of organisms occurring in horizontal bands from the upper littoral zone to the sub-littoral. Lichens and gastropods generally dominate the upper shore, followed lower down by barnacles, mussels and algae in the sub-littoral. Each species' range is dependent on how well each is adapted to the biological and physiological factors associated with desiccation and predation. Those resident at the upper littoral zone are well adapted to avoid desiccation, while those lower down face pressure from biological competition and predation. It has been suggested that this pattern of zonation is essentially universal throughout temperate rocky shores (Stephenson \& Stephenson, 1949). However, the pattern of zonation in the Cook Strait region is somewhat different to that expected, because large areas of Wellington's South Coast are virtually devoid of mussels (Fig. 1.1). North of the 'transition zone' mussels occur in high densities within the Harbour; the intertidal is dominated by Mytilus galloprovincialis, within these populations smaller clumps of Aulacomya maoriana are found. Perna canaliculus is usually found lower in the intertidal zone. South of the transition zone mussels are absent, the substrate they would occupy is barren with the exception of the occasional barnacle. The rocky substrate of this coastline appears to be well suited to mussel colonisation, and with the exception of mussels, the expected pattern of zonation is present (Morton \& Miller, 1968).

Wellington Harbour displays a different pattern of zonation compared to Wellington's South Coast. The Harbour supports large populations of intertidal mussels (Perna canaliculus, Aulacomya maoriana, Mytilus galloprovincialis) which occur in dense beds within the Harbour and occupy any suitable substrate. On the opposite side of Cook Strait, the inner Marlborough Sounds also support large commercial mussel 
farms; these produce the majority of New Zealand's mussels (Perna canaliculus) for export and local consumption. Given the relatively close proximity of these two large mussel populations, it would be reasonable to expect that a large expanse of rocky reef habitat, as seen on Wellington's South Coast, would support mussels.

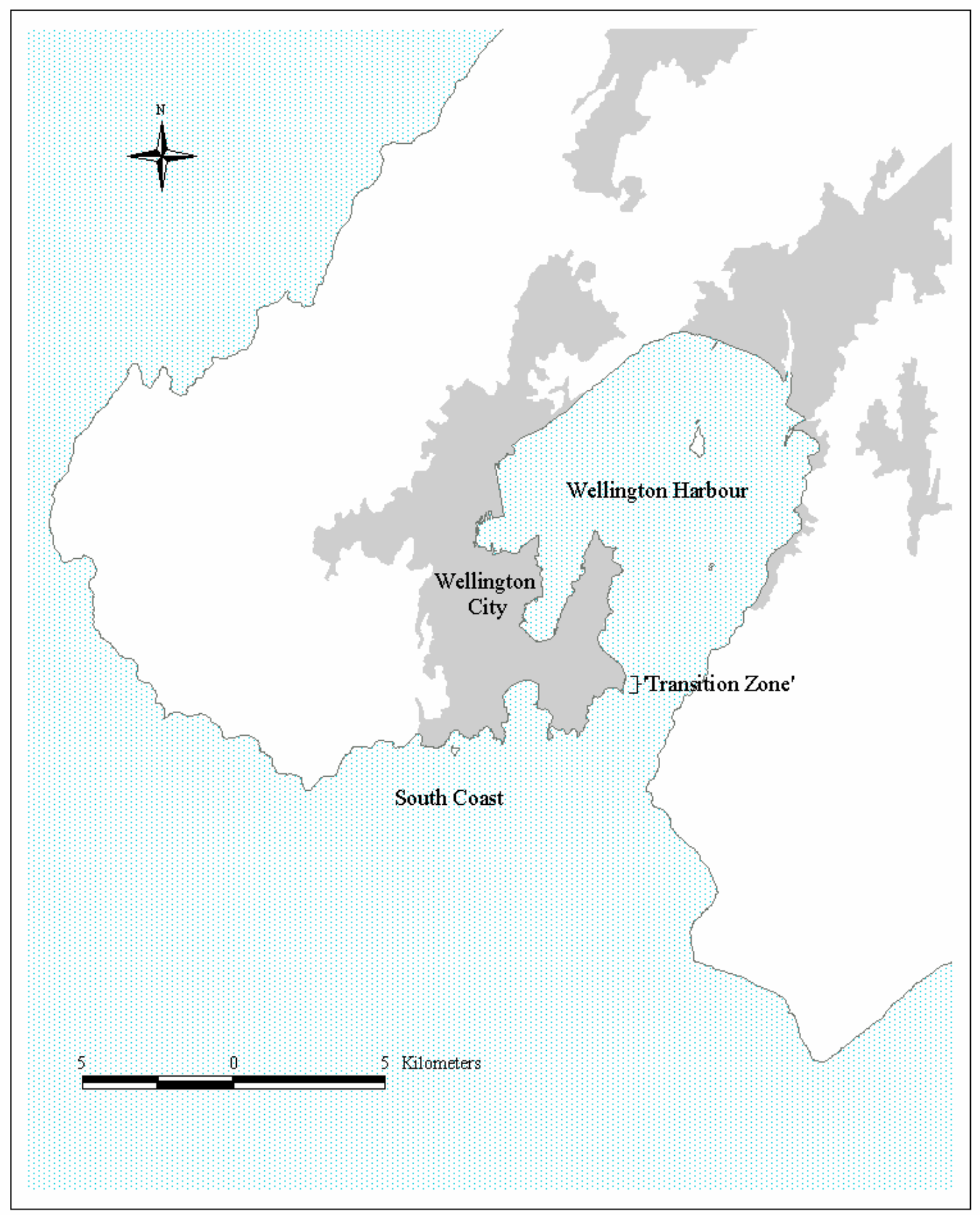

Figure 1.1. Harbour and Coastal area showing 'transition zone' 
Any larvae derived from these populations may not remain in the area long enough to seed the Coast ${ }^{1}$, but larvae are obviously available to populate nearby areas, between which the Coastal area is situated.

Mussels reproduce by releasing gametes into the water column where fertilisation occurs. Larvae then remain in the plankton for a period of approximately two to four weeks, during most of this time they feed actively in the water column (Lutz \& Kennish, 1992; Seed \& Suchanek, 1992). When conditions are favourable, mussels will settle onto substrate and undergo metamorphosis to begin the sessile mode of life (Lutz \& Kennish, 1992). Mussels are filter-feeding organisms that rely on particulate matter in the plankton for food. Individual mussels have the ability to clear particles from several litres of water an hour (Widdows \& Johnson, 1988; Gardner, 2000), and given the biomass of mussels on a densely covered rocky coastline, they are of considerable ecological importance. Mussels have also been used as biological indicators of contamination (Widdows \& Johnson, 1988; Widdows \& Donkin, 1992) and are known to alter feeding behaviour according to seston composition (Bayne et al., 1987; Hawkins et al., 1996) and resorb tissues in unfavourable biological conditions (Bayne, 1973).

It is the intention of this study to investigate the possible reasons for the absence of mussels from Wellington's South Coast, and ascertain which factor or factors are preventing the establishment of adult populations. Given the biology of mussels as briefly outlined above, this thesis was designed to investigate each possible cause of the mussel distribution (Fig. 1.2). Figure 1.2 outlines the framework in which the current study sits and describes some of the possible avenues open for investigation. As it was not possible to conduct all the work detailed in Figure 1.3, an outline of the actual work undertaken appears in Section 1.3.

\footnotetext{
${ }^{1}$ From here onwards the capitalised usage of 'Coast' is used to describe the specific area of Wellington's South Coast that is devoid of mussels. This area will be more formally described in Section 1.2 below, and in Table 2.1 in Chapter Two as it pertains to the collection of specific data.
} 


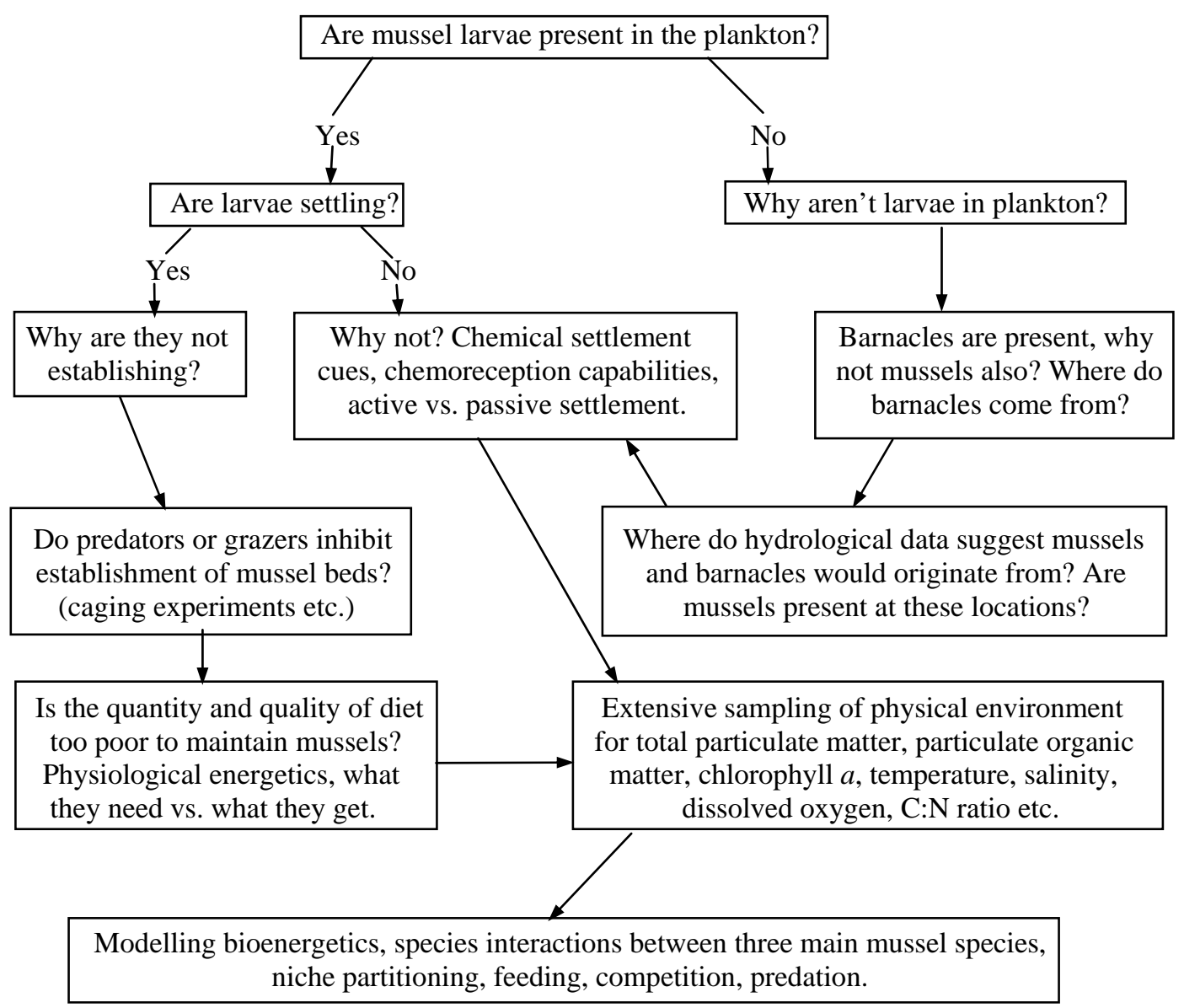

Figure 1.2. Flow diagram showing the initial design of the study and proposed methods for determining the reason(s) for the described distribution of mussels.

\section{Wellington Harbour and Cook Strait Hydrology}

The surface area of Wellington Harbour is approximately $85 \mathrm{~km}^{2}$ and has a maximum width of $11.1 \mathrm{~km}$. It is almost fully enclosed with a maximum depth of $31 \mathrm{~m}$, an average depth of $20 \mathrm{~m}$ and an entrance width of only $1.8 \mathrm{~km}$ (Booth, 1975). The water volume has been calculated as approximately 1320x10 $\mathrm{m}^{3}$ (Maxwell, 1956). The Harbour experiences semi-diurnal tides with a maximum tidal range of approximately $1.5 \mathrm{~m}$ and a mean of approximately $0.75 \mathrm{~m}$ (Maxwell, 1956). As such, the spring and neap tidal exchange has been estimated to be 88 and $82 \times 10^{6} \mathrm{~m}^{3}$ respectively, which equates to a total flushing time of approximately $10 \mathrm{~d}$ (Heath, 1977). Water from the Harbour generally flows in a clockwise direction on flood tide and an anti-clockwise direction on the ebb tide; this results in a net clockwise flow within the Harbour (Heath, 1977) (Fig 1.3). 
The total Harbour catchment is $725 \mathrm{~km}^{2}$, of this the Hutt River catchment makes up $630 \mathrm{~km}^{2}$ (Booth, 1975). Freshwater discharge from the Hutt River ranges from a minimum of $\approx 2.6 \times 10^{6} \mathrm{~m}^{3}$ to a maximum of $\approx 180 \times 10^{6} \mathrm{~m}^{3}$ (Maxwell, 1956). After periods of prolonged rainfall a freshwater lens $\approx 1 \mathrm{~m}$ deep extends out from the Hutt River along the eastern edge of Wellington Harbour, this is often observed as far south as Matiu-Somes Island and on occasion as far south as the Front Lead (pers. obs.). Other sources of freshwater input include three small streams, Kaiwharawhara, Ngauranga and Korokoro. These inputs are very small compared to that of the Hutt River (Maxwell, 1956).

Cook Strait hydrology is complicated in that it receives inputs from three major currents (Fig. 1.3). The Southland Current, which moves northward along the eastern coast of the South Island, consists of Subtropical and Subantarctic water. This current has a dominant effect on surface water immediately south of Cook Strait (Heath, 1971). Analysis of wind off the north Canterbury coast has shown that the Southland Current is likely to increase transport in winter, which could account for the large variations in temperature and salinity during winter months (Heath, 1971). The East Cape Current is a sub-surface, Subtropical current that travels down the eastern coast of the North Island and enters Cook Strait from the southeast. The D’Urville Current consists of surface and sub-surface Subtropical water that travels up the west coast of the South Island and enters Cook Strait from the north. To the west of Cook Strait lies the western shelf, which is a submarine land bridge linking the North and South Islands, above which the water is relatively shallow $(100 \mathrm{~m})$. This effectively excludes the deeper water of the Tasman Sea from entering Cook Strait (Bowman et al., 1983). The predominant northerly winds exert a strong influence over this relatively shallow area and push water from the D'Urville current southward into Cook Strait (Bowman et al., 1983). Bowman et al. (1983) observed this warm, low nutrient current entering Cook Strait as far as Cape Terawhiti on two occasions. Both of these observations occurred at times of moderate northerly winds with a maximum speed of 30 knots. These three currents mix at a depth of approximately $100 \mathrm{~m}$ in an area of Cook Strait west of Cape Terawhiti called the Narrows. In this area, Heath (1971) has documented current flows to be generally between 12.5-25 $\mathrm{cm} \mathrm{s}^{-1}$ eastward toward the southern coast of the North Island (Fig. 1.3). 


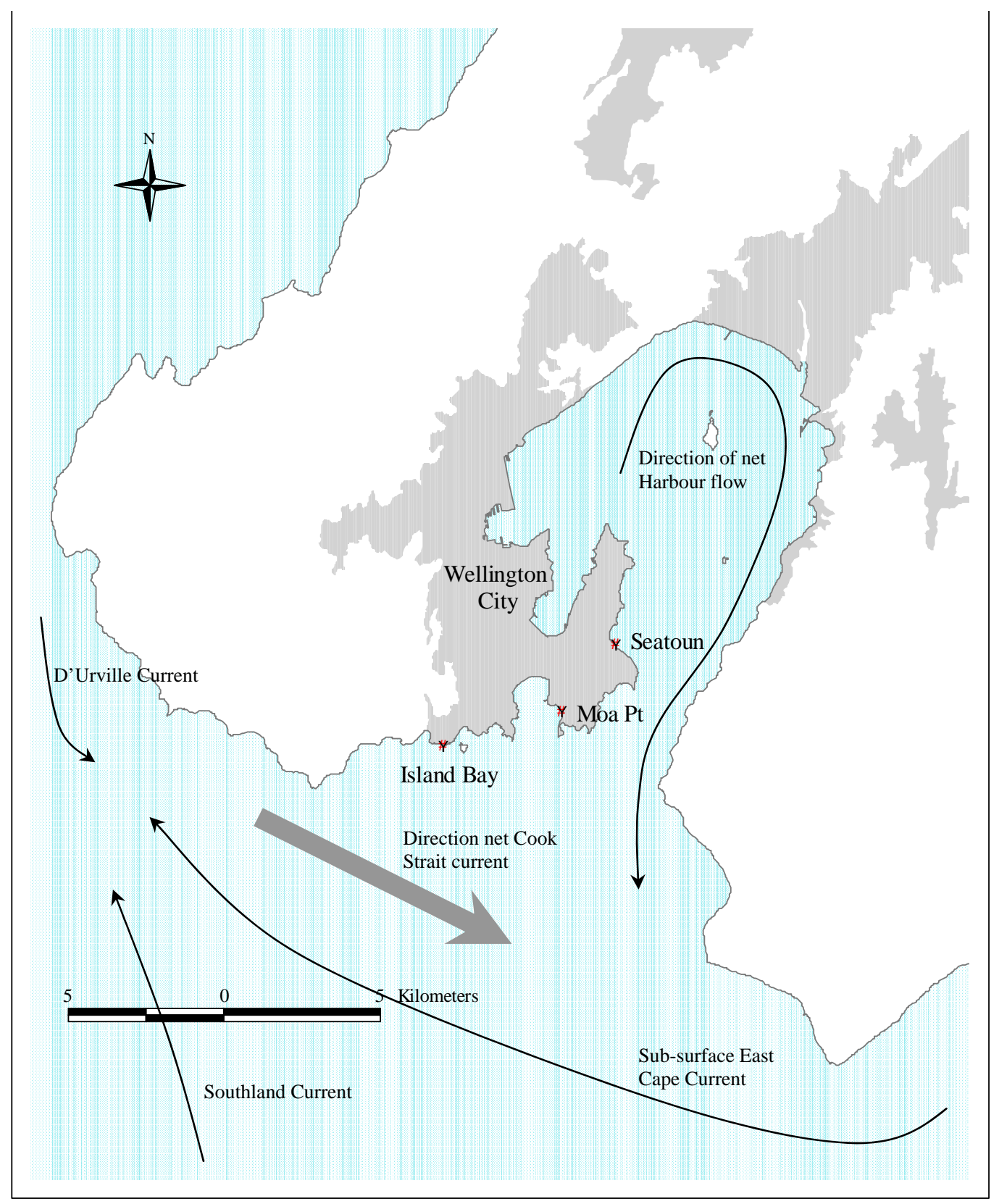

Figure 1.3. Map of general surface and sub-surface currents in Cook Strait and Wellington Harbour

\subsection{Description of mussel distributions in the study area}

As described above, mussels occur in large, dense populations of three coexisting species within Wellington Harbour. On the South Coast however, only occasional individuals of one species (M. galloprovincialis) can be seen in a few isolated areas, and these animals are usually only found in crevices. The transition between these two distributions is relatively abrupt. It occurs over a distance of approximately $750 \mathrm{~m}$ at 
the entrance to Wellington Harbour (Fig. 1.1). A survey was conducted on 30 September 2000 in order to quantify this transition.

The $750 \mathrm{~m}$ transition zone was walked at low tide, just above the water line. This time was chosen so as to give access to the intertidal zone where mussels preferentially inhabit. Every ten metres a 0.5 x 0.5 m quadrat was put down and the number of all three mussel species within it was counted. If any quadrat contained more than 100 animals it was counted as $>100$. On the same day, the area was walked a second time, this time every $75 \mathrm{~m}$, mussels within ten adjacent quadrats were counted from the mid-shore downward so as to form a 5 x $0.5 \mathrm{~m}$ strip transect. As with the first survey, mussels were counted within the intertidal zone (Fig. 1.4).

Mussel numbers increased about halfway along the 'transition zone' moving from south to north (Fig. 1.4). Prior to this, mussels were initially entirely absent; they then appeared in small groups, mainly confined to cracks in the rocks. The mussel groups slowly increased in number and frequency further north until they occupied most of the suitable rocky substrate. Of the three species counted, $M$. galloprovincialis was by far the most dominant species.

The distribution of mussels on the eastern side differs from that described above and is complicated by a number of factors. Firstly, a sewer outfall located at Pencarrow Head may disturb the natural nutrient levels in this location. In addition to this, nutrient-rich Harbour water generally moves eastward once in Cook Strait (Heath, 1971), thus Harbour water is more influential on the eastern side (Pencarrow to Fitzroy Bay, Fig 1.3). Secondly, the substrate along the eastern side of the Harbour entrance is not as homogeneous as the western side. The rocky substrate is broken up by numerous stretches of pebble beach along the eastern side of the Harbour entrance and coastline beyond. This makes the detection of any mussels transition more difficult due to patchy nature of available habitat. 

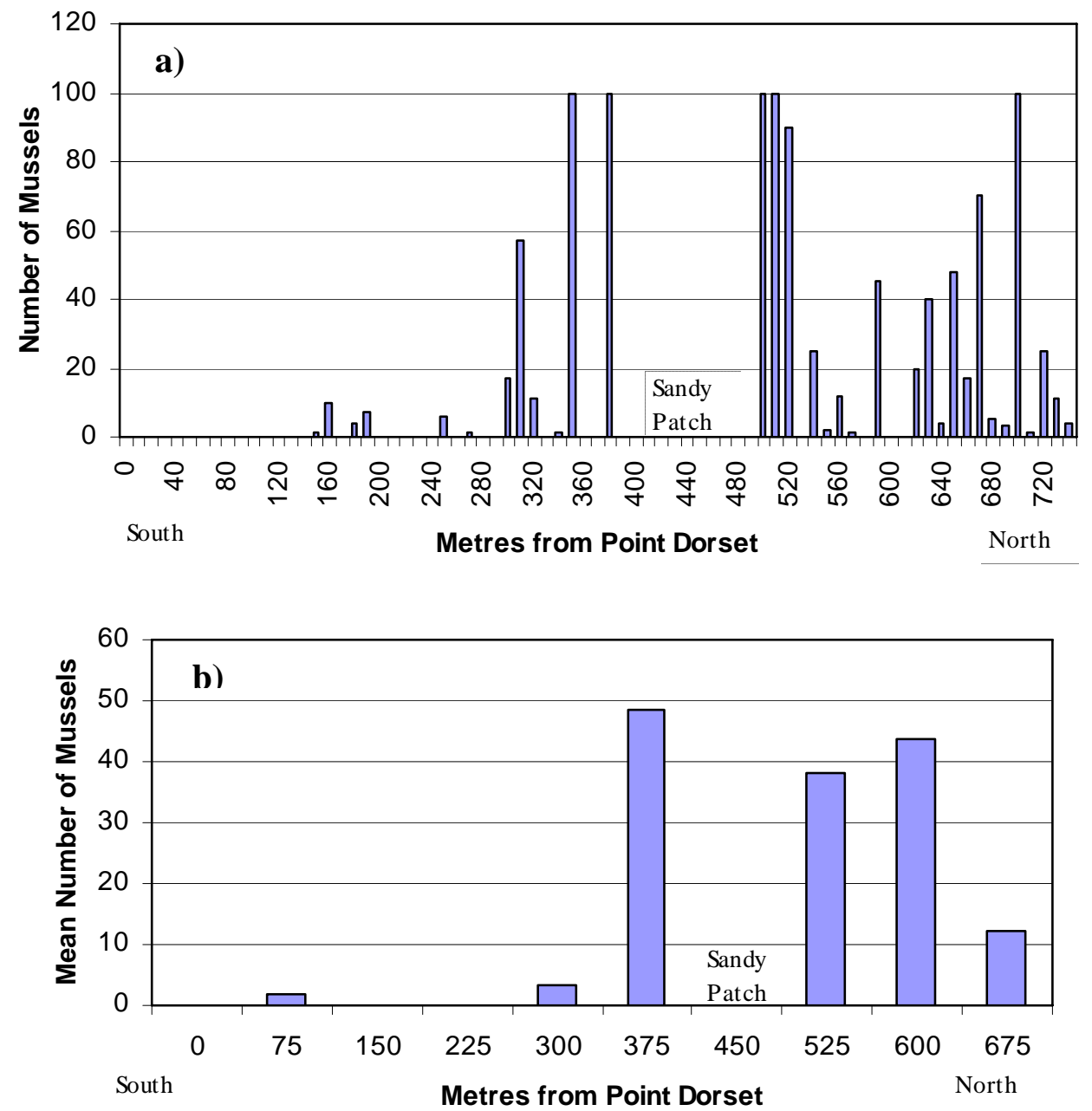

Figure 1.4. Mussel distribution at 'transition zone', Point Dorset represents the southern (Cook Strait) end of the zone. Bars represent a) number of all three mussel species within quadrats at $10 \mathrm{~m}$ intervals and $\mathbf{b}$ ) mean number of all three mussel species within ten adjacent quadrats running from the mid-shore to the lower shore at $75 \mathrm{~m}$ intervals.

\subsection{Thesis Outline}

This study attempted to address each possible cause of the aforementioned mussel distribution and determine its relevance (Fig 1.2). Not all work outlined in Figure 1.2 was conducted, and as the thesis progressed new work was added. Each of the following data chapters addresses a separate component of the study in order to assess its importance as a limiting factor in the distribution of mussels on Wellington's South Coast.

Chapter Two: This chapter describes characteristics of the water mass at each of eight sites both inside the Harbour and on the Coast. Water temperature, salinity, 
dissolved oxygen, organic and particulate content, carbon and nitrogen content and chlorophyll $a$ were all measured. These data help to establish whether differences exist between Harbour and Coastal water masses that may explain the absence of mussels on the Coast.

Chapter Three: For mussels to successfully colonise any habitat, they must be transported as larvae in the plankton to a new habitat and settle onto the substrate. Planktonic mussel larvae are investigated in this chapter to establish the density of mussel larvae in the Harbour and on the South Coast. These data determine whether inadequate larval supply is limiting the establishment of mussels on the Coast. Mussels may be present in the plankton, but if for some reason they are not able to settle onto the substrate then they will not establish adult populations. Settlement of mussels onto artificial substrates both inside and outside the Harbour was investigated as a possible factor explaining mussel absence along the Coast.

Chapter Four: Condition index and gonad mass form the basis of a comparison between Harbour mussels and those collected from the Harbour and held on the South Coast at the Island Bay Marine Laboratory (IBML). These experiments attempted to establish whether mussels held at IBML, and feeding on ambient Cook Strait water, lost condition compared to the Harbour population. The ratio of RNA:DNA was also used as a biochemical index to test this hypothesis. These data also provided an insight into the natural condition and gonad maturation cycles of each of the three mussel species.

Chapter Five: The scope for growth of each species was established at various times of the year to determine the net energy balance available to each species. The quantification of energy acquisition and utilisation of each species gave further insight into the possibility of the dietary inadequacy of Cook Strait water.

Chapter Six: Bioenergetic modelling was used to integrate data from previous chapters to give a better overall picture of the ability of each mussel species to survive at various locations inside and outside the Harbour at different times of the year. 
Chapter Seven: Data from all previous chapters are summarised and general conclusions drawn as to the reason or reasons for the absence of mussels from Wellington’s South Coast. 


\section{CHAPTER TWO}

\section{Characteristics of Water Samples at Harbour and Coastal Sites}

\subsection{Introduction}

To explain any anomalous distribution of marine animals, investigating the properties of the water masses at a number of sites in and around the area of interest is an obvious place to start. Wellington Harbour is a relatively small and shallow body of water that has a high freshwater input and a relatively long flushing time, whereas Cook Strait is a dynamic, high-energy environment with little terrigenous input (Chapter One). Given the difference in hydrology between Wellington Harbour and Cook Strait one may expect to find differences in the water masses between Harbour and Coastal sites.

The influence of the water mass in which an organism lives is obviously of primary importance to any marine animal. This is particularly so in the case of filter feeding bivalves, which rely on removing food particles directly from the water column. Any differences in water quality between Harbour and Coastal sites may assist in explaining the results of other experiments such as larval abundance and settlement, condition index comparisons, gonad maturation and scope for growth.

Various seawater characteristics have been linked to key reproductive and developmental activities in bivalves. Temperature and the availability of food of good quantity and quality are often correlated with gonad development and spawning in mussels (Wilson \& Hodgkin, 1967; Bayne \& Worrall, 1980; Seed \& Suchanek, 1992; Smith \& Strehlow, 1983; Cáceres-Martínez \& Figueras, 1998). These relationships will be examined in more detail in subsequent chapters.

Many studies have investigated the feeding responses of filter feeding bivalves to the seston characteristics to which they are exposed. Generally, mussels have an ability to vary feeding response according seston quality and quantity (Bayne et al., 1993; 
Hawkins et al., 1996; Cranford \& Hill, 1999; Denis et al., 1999; Wong \& Cheung, 1999). It is therefore essential to characterise the seston both within the Harbour where mussels are plentiful, and at Coastal sites where mussels are absent. Subsequent experiments to determine mussel response to ambient Coastal waters may show that these waters are unsuitable for mussel growth.

It has been suggested that Wellington Harbour and Cook Strait are to some degree separate systems (Booth, 1975; Gardner, 2000). However, no comprehensive, multisite, inter-annual sampling of the water column has been conducted. Such a study would allow for a comparison between water column variables within the Harbour and on the Coast. Water sampling is also necessary for determining the nature and degree of temporal and spatial variations in water characteristics. It is widely known that water characteristics vary both spatially and temporally. This study enables changes in seston to be assessed, and thus determine whether seston differs among sites and seasons. The implications and effects of any observed differences will be discussed in the relevant chapters. These data will also be used in bioenergetic models to determine at which of the Coastal sites, and at what time of the year, mussels would experience conditions favourable for survival and growth.

\subsection{Materials and Methods}

Water samples were collected at approximately 2-4 wk intervals between September 1998 and February 2000. The University research vessel $R V$ Raukawa Challenger was used to sample eight sites in the Harbour and around the South Coast (Fig. 2.1 \& Table 2.1).

Table 2.1. Description of sample sites, Harbour or Coastal designations and position.

\begin{tabular}{l|cccc}
\hline \multicolumn{1}{c|}{ Site } & Mussels & Harbour or Coastal & \multicolumn{2}{c}{ Position } \\
\cline { 4 - 5 } & & Designation & Latitude & Longitude \\
\hline Oteranga Bay & Absent & Coastal & $41^{\circ} 19.259^{\prime} \mathrm{S}$ & $174^{\circ} 37.838^{\prime} \mathrm{E}$ \\
Island Bay & Absent & Coastal & $41^{\circ} 21.247^{\prime} \mathrm{S}$ & $174^{\circ} 45.938^{\prime} \mathrm{E}$ \\
Outer Dorset & Absent & Coastal & $41^{\circ} 20.070^{\prime} \mathrm{S}$ & $174^{\circ} 50.390^{\prime} \mathrm{E}$ \\
Inner Dorset & Present & Harbour & $41^{\circ} 19.784^{\prime} \mathrm{S}$ & $174^{\circ} 50.406^{\prime} \mathrm{E}$ \\
Kau Bay & Present & Harbour & $41^{\circ} 17.139^{\prime} \mathrm{S}$ & $174^{\circ} 49.720^{\prime} \mathrm{E}$ \\
Eastbourne & Present & Harbour & $41^{\circ} 16.988^{\prime} \mathrm{S}$ & $174^{\circ} 54.332^{\prime} \mathrm{E}$ \\
Pencarrow Head & Absent & Coastal & $41^{\circ} 21.842^{\prime} \mathrm{S}$ & $174^{\circ} 50.840^{\prime} \mathrm{E}$ \\
Turakirae Head & Absent & Coastal & $41^{\circ} 26.273^{\prime} \mathrm{S}$ & $174^{\circ} 54.578^{\prime} \mathrm{E}$ \\
\hline
\end{tabular}


At each site, nine samples were taken from surface water: 3 x 2 l samples to determine total particulate matter (TPM), particulate organic matter (POM) and percent organic matter (PCOM), 3 x 2 l samples for chlorophyll $a$ and $3 \times 1$ l samples for C:N ratio and particle counts. Given the high degree of mixing at most sites, particularly on the Coast, it was thought that vertical sampling was not necessary. All samples were filtered on the day of collection and the volume of each sample was measured so all samples could be corrected to a standard volume.

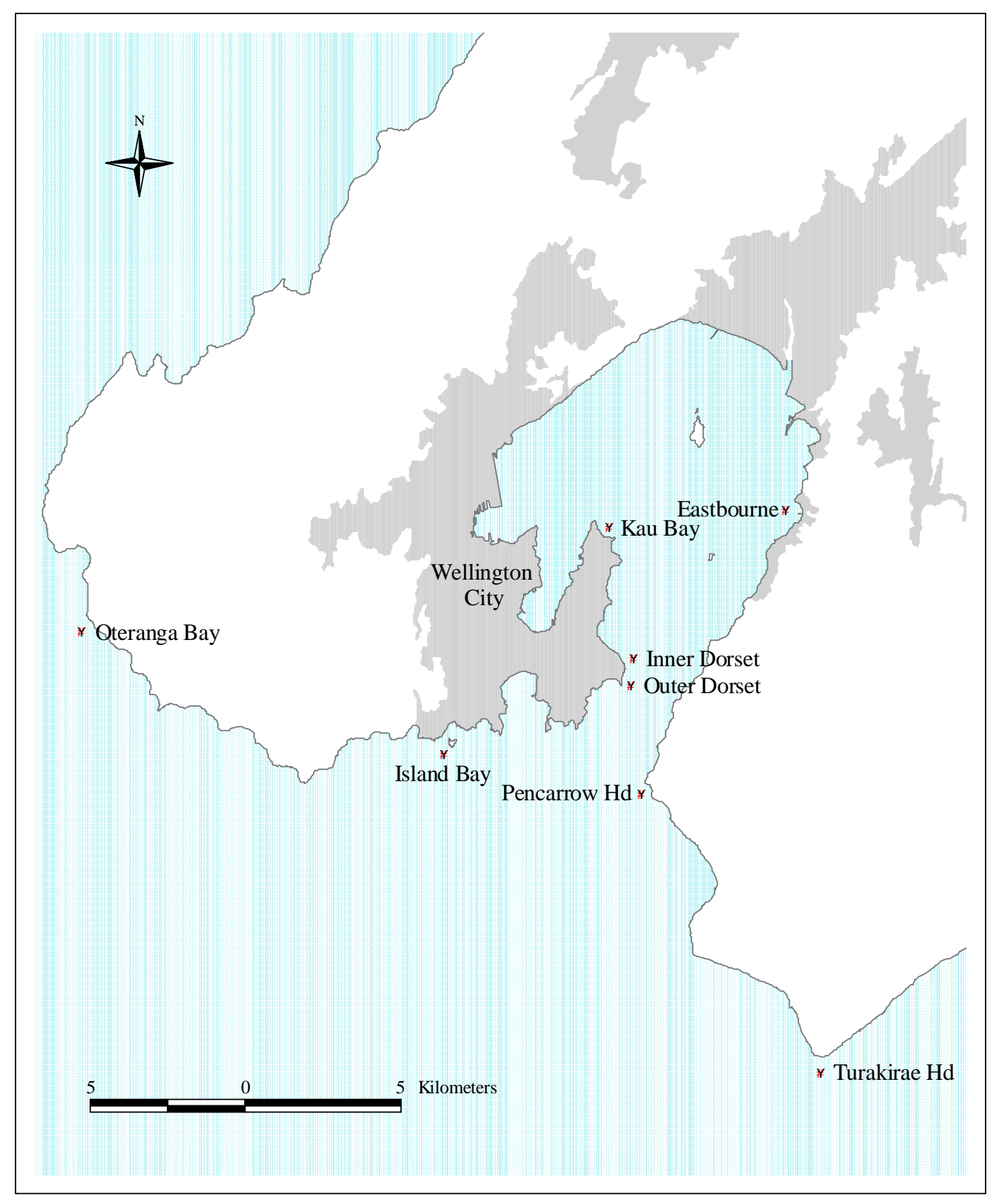

Figure 2.1. Map of sites where water samples were collected. 
All filters were weighed on an Ainsworth ACA $100 \mathrm{KS}$ balance to $0.0001 \mathrm{~g}$. Water temperature and salinity were measured using a YSI 30 meter $\left( \pm 0.1^{\circ} \mathrm{C}\right.$ and $\pm 0.1 \%$ ), and dissolved oxygen was measured using a YSI 55 meter $( \pm 0.1 \%)$.

\section{Total particulate matter (TPM), particulate organic matter (POM) and percent organic matter (PCOM)}

The volume of all samples was measured so data could be standardised to one litre, volumes usually ranged between 1950 and $2000 \mathrm{ml}$. Samples were then filtered on to a $47 \mathrm{~mm}$ pre-ashed, pre-weighed Whatman GF/C filter and dried at $60^{\circ} \mathrm{C}$ for $24 \mathrm{~h}$. Filters were then weighed again to determine their dry weight or total particulate matter (TPM), and ashed at $450^{\circ} \mathrm{C}$ for $\approx 24 \mathrm{~h}$. Filters were then weighed a final time to determine the ash weight. The particulate organic matter (POM) is then calculated as TPM-ash weight. Percent organic matter (PCOM) is the percentage of TPM that is organic, and is calculated as (POM / TPM)*100.

\section{Chlorophyll $a$}

Two litre samples were filtered on to $47 \mathrm{~mm}$ Whatman GF/C filters and wrapped in aluminium foil for storage at $-20^{\circ} \mathrm{C}$ until determination of chlorophyll $a$ concentration. Samples were not left in storage for more than three weeks as recommended by Arar and Collins (1992). Chloropyhll $a$ was determined using the acetone extraction technique (Arar and Collins, 1992). To determine chlorophyll $a$, each filter was put into a cuvette and $5 \mathrm{ml}$ of 90\% HPLC grade acetone were added and the top was covered with parafilm to prevent evaporation. Samples were refrigerated overnight to allow extraction and measured the following day using a Turner Designs AU-10 fluorometer. After the initial reading in the fluorometer three drops of $0.1 \mathrm{M} \mathrm{HCl}$ were added to each sample to acidify phaeopigments and a second measurement was made one minute later. Chlorophyll $a$ concentration is the difference between the two measurements after adjustments for cuvette volume are made.

\section{Particle Counts}

Particle counts were made using a Z1 Coulter Counter. Three replicate counts were made of $1.0 \mathrm{ml}$ of seawater in two size classes, 2.5-5.0 $\mu \mathrm{m}$ and 5.0-63.0 $\mu \mathrm{m}$. This volume was thought to be sufficient given that counts of the less numerous 5.0-63.0 
$\mu$ m particles were routinely between 500-1000 at sites with the lowest total particle count.

\section{Carbon to Nitrogen Ratio}

Water samples were filtered on to a $25 \mathrm{~mm}$ pre-ashed, Whatman GF/C filter and the filters wrapped in ashed aluminium foil to prevent contamination. Samples were handled with forceps at all times and were stored at $-20^{\circ} \mathrm{C}$ until processing. All analyses were carried out using an isotope ratio mass spectrometer by Drs Karyne Rogers and Graeme Lyon at the Institute of Geological and Nuclear Sciences (IGNS) in Gracefield, Lower Hutt. Measurements were normalised to VPDB (International Standard) using NBS-22 (International Standard) and ANU-sucrose (International Standard) with a precision of $\pm 0.1 \%$ for $\delta 13 \mathrm{C}$; and to $\delta$ Air using N-1 (International Standard) with a precision of $\pm 0.3 \%$ for $\delta 15 N$.

\section{Data Analysis}

It was not always possible to collect a full array of samples at every site on every occasion. This was due to gear failure and adverse weather conditions. Therefore, it was not possible to do a full multivariate analysis on the complete data set as too many of the data were eliminated for the test to be effective. It was decided to reduce the data set to a group in which most or all of the data were represented across all sites and times. The multivariate analysis was conducted to test for differences among sites and months using the following parameters: water temperature, total particulate matter (TPM), particulate organic matter (POM), percent organic matter (PCOM) and chlorophyll $a$. In the initial analysis, all sites were entered separately; the test was then repeated using data grouped into Harbour and Coastal sites. Separate ANOVA were conducted on each of the 11 variables collected at each site, however, there were problems in verifying the assumptions of equal variance and normality. Therefore a non-parametric Kruskal-Wallis test was conducted on each variable for differences among sites for both ungrouped and grouped data. The relationship among variables will be analysed in conjunction with the biological data gathered in the subsequent chapters. 


\subsection{Results}

The data displayed in Figures 2.2-2.12 have been grouped by season as follows: Spring: September-November; Summer: December-February; Autumn: March-May; Winter: June-August. For reasons of clarity error bars have been omitted from graphs in this section, although all data appear in the figures in Appendix A. To give an indication of variance, means and standard deviations for temperature, salinity, dissolved oxygen, TPM and POM are given in Table 2.2. Similar data appear in Table 2.3 for PCOM, chlorophyll $a$, particle count, C:N, percent $\mathrm{C}$ and percent $\mathrm{N}$.

The highest temperature recorded was in the Harbour during summer (Eastbourne, $21.3^{\circ} \mathrm{C}$ ) and lowest temperature recorded was in winter (Kau Bay, $10.3^{\circ} \mathrm{C}$ ), also in the Harbour. Variation in temperature was highest at sites inside the Harbour (Fig. 2.2 \& Table 2.2). Mean temperatures during the spring and autumn were more consistent across sites, although the temperature range was greatest at Harbour sites, particularly in the spring (e.g. Eastbourne $12.0-17.3^{\circ} \mathrm{C}$, Island Bay $12.5-14.0^{\circ} \mathrm{C}$ ) (Appendix A1). Temperature was not significantly different in an ANOVA among all sites, but was significantly different between Harbour and Coastal sites when data were grouped (Table 2.4).

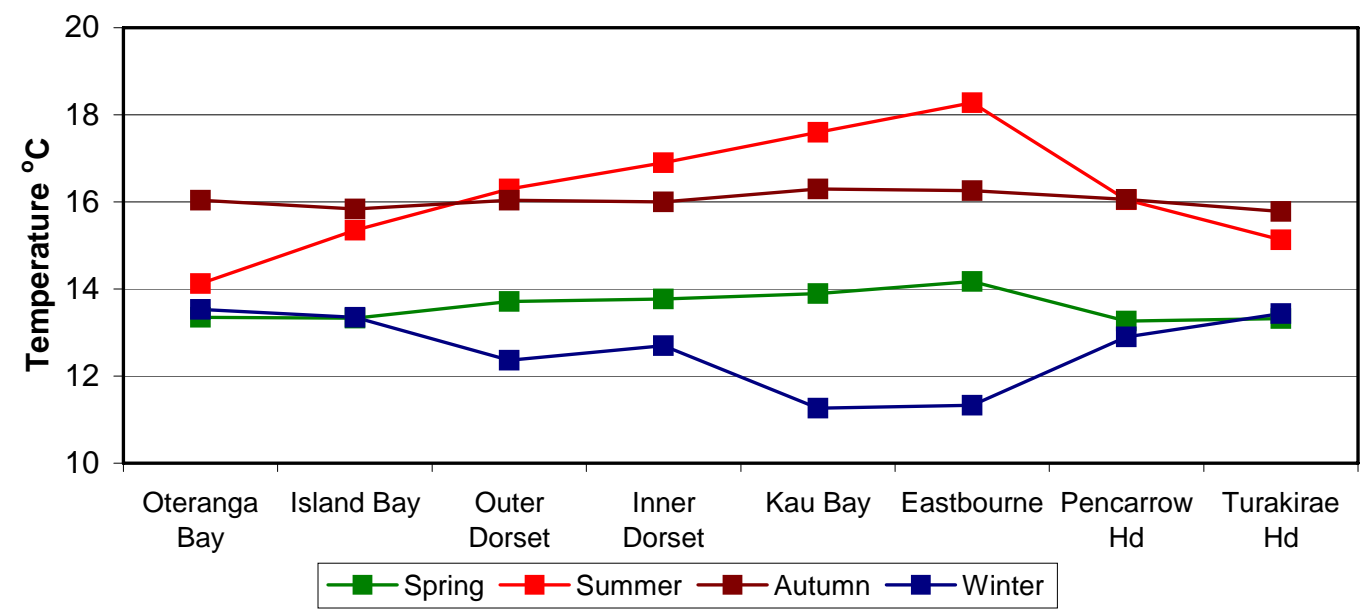

Figure 2.2. Mean seasonal variation in water temperature at all sites.

Salinity was lower at Harbour sites than Coastal sites (Fig. 2.3). Outside the Harbour, salinity was relatively constant and generally ranged from 34.5-35.0 \%o. Salinity variation was greater in the Harbour (Table 2.2), varying at Eastbourne between a mean of $32.17 \%$ (28 \% min.) in spring to a mean of $33.55 \%$ in autumn (Appendix 
A2). A non-parametric Kruskal-Wallis analysis showed salinity to be significantly different among all sites and when grouped into Harbour and Coastal sites (Table 4.6).

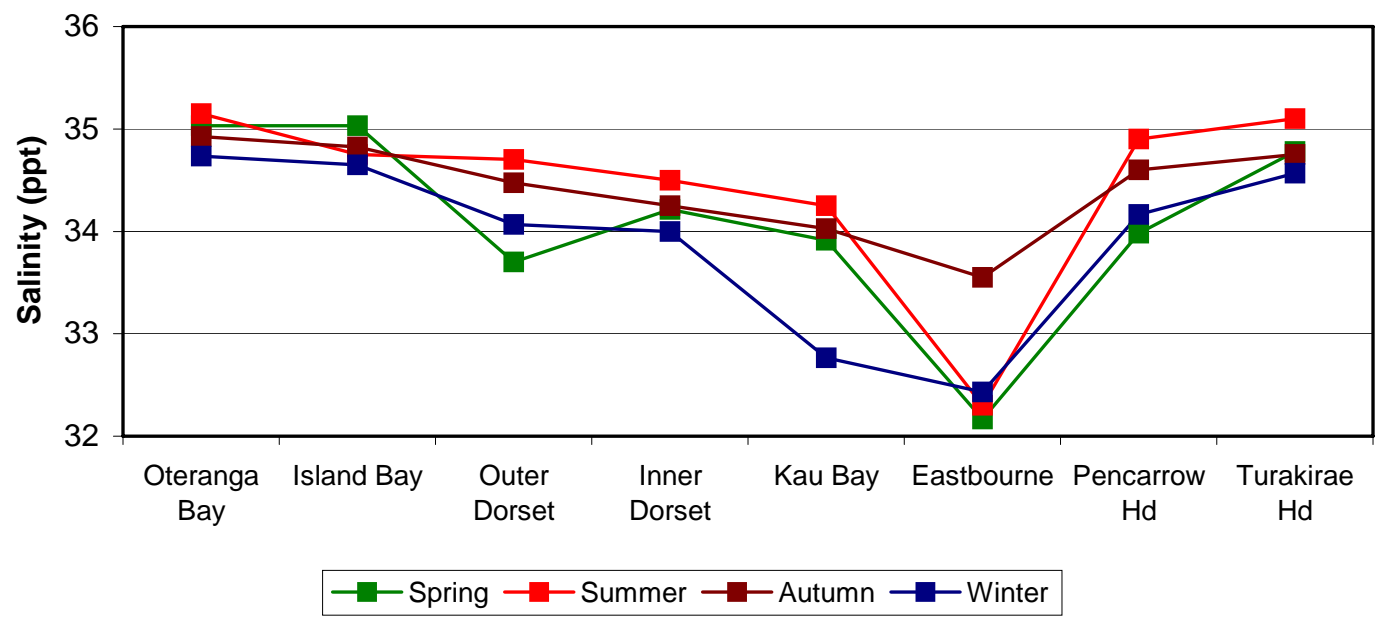

Figure 2.3. Mean seasonal variation in salinity at all sites.

In the Harbour dissolved oxygen was slightly higher than at Coastal sites in summer and spring, whereas during autumn there was very little difference between Harbour and Coastal sites (Fig. 2.4). The dissolved oxygen in winter however, was lower in the Harbour when compared to the Coast. As with temperature and salinity, the variation at Harbour sites was greater than that seen at Coastal sites (Table 2.2), for example Kau Bay ranged from 75.2-104.4\%, while Turakirae Head ranged from 91.9-97.3\% (Fig. 2.4 \& Appendix A3). A non-parametric Kruskal-Wallis analysis showed dissolved oxygen to be significantly different among all sites, however no significant difference was detected when sites were grouped into Harbour and Coastal (Table 4.6).

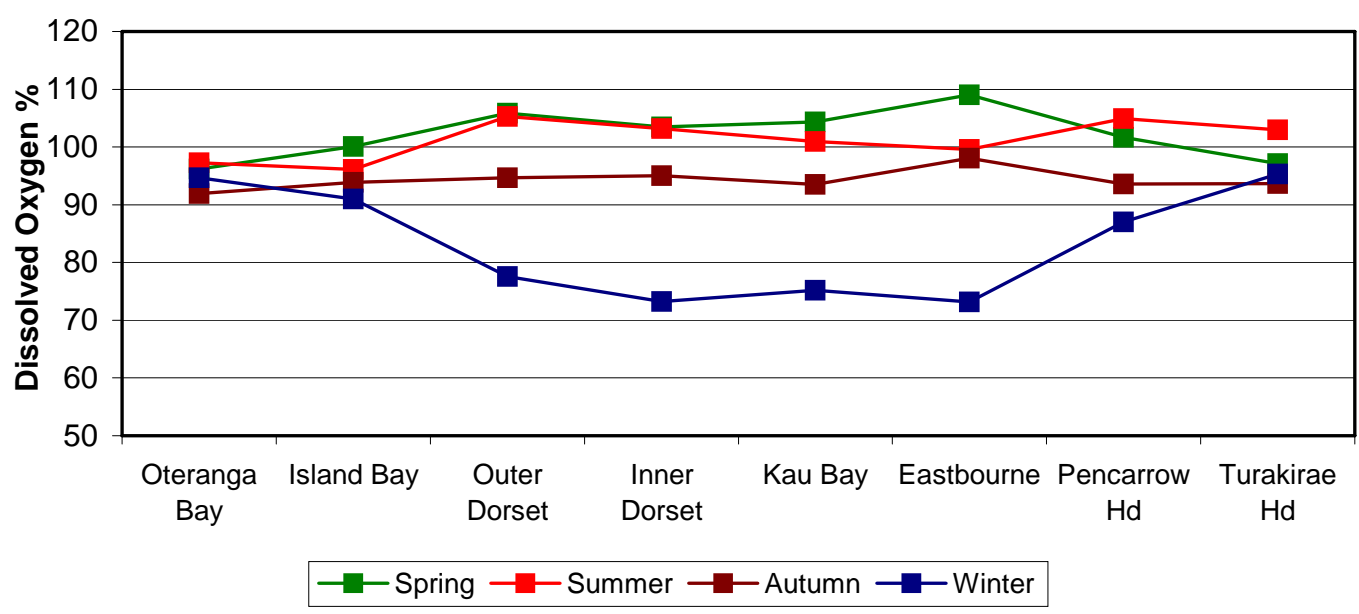

Figure 2.4. Mean seasonal variation in dissolved oxygen at all sites. 
Total particulate matter (TPM) showed only small variation between Harbour and Coastal sites, TPM generally ranged between 12-15 $\mathrm{mg} \mathrm{l}^{-1}$ across all sites (Fig. 2.5). The highest variation in TPM was observed at Island Bay and Eastbourne (Table 2.2), variation in TPM was lowest at Kau Bay and Inner Dorset, both Harbour sites. However, the degree of seasonal variation within each site was very similar between Harbour and Coastal sites (Appendix A4). The lowest TPM was recorded in the autumn months, while the highest TPM was most often recorded in spring (Fig. 2.5). An ANOVA did not detect any significant difference in TPM among all sites, however a significant difference was found between the grouped sites (Table 2.4).

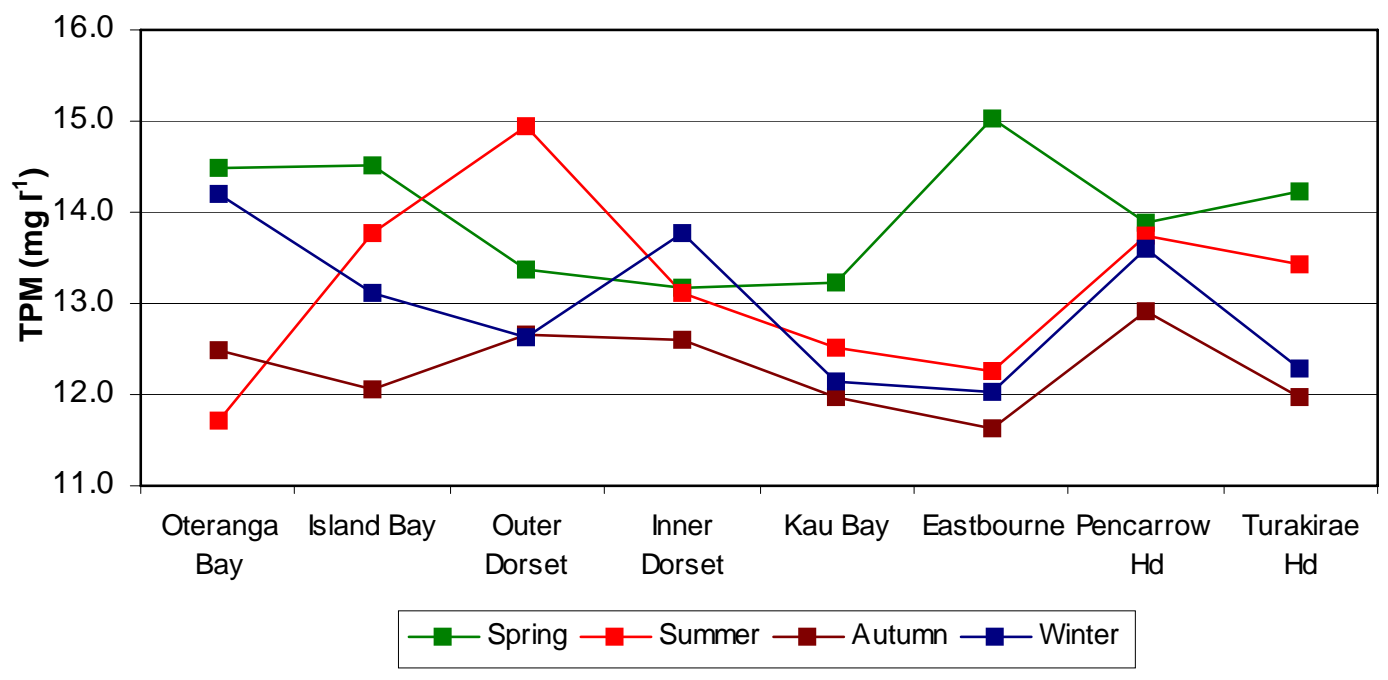

Figure 2.5. Mean seasonal variation in total particulate matter (TPM) at all sites.

Particulate organic matter (POM) was similar at Harbour and Coastal sites (Table 2.2). POM at Harbour sites was marginally higher in autumn and to a lesser extent in summer. In winter and spring there is very little difference in POM between Harbour and Coastal sites (Fig. 2.6). POM was highest in the spring and lowest in winter, similar levels of POM were recorded in summer and autumn, with autumn slightly higher (Fig. 2.6). The variation at each site is similar at Harbour and Coastal sites (Table 2.2). The greatest variation in mean seasonal POM was recorded at Eastbourne (2.6-3.6 $\mathrm{mg} \mathrm{l}^{-1}$ ), while the lowest variation in POM was recorded at Outer Dorset (2.8-3.2 $\mathrm{mg} \mathrm{l}^{-1}$ ) (Fig. 2.6 \& Appendix A5). An ANOVA detected no significant difference in POM among all sites and between grouped sites (Table 2.4). 


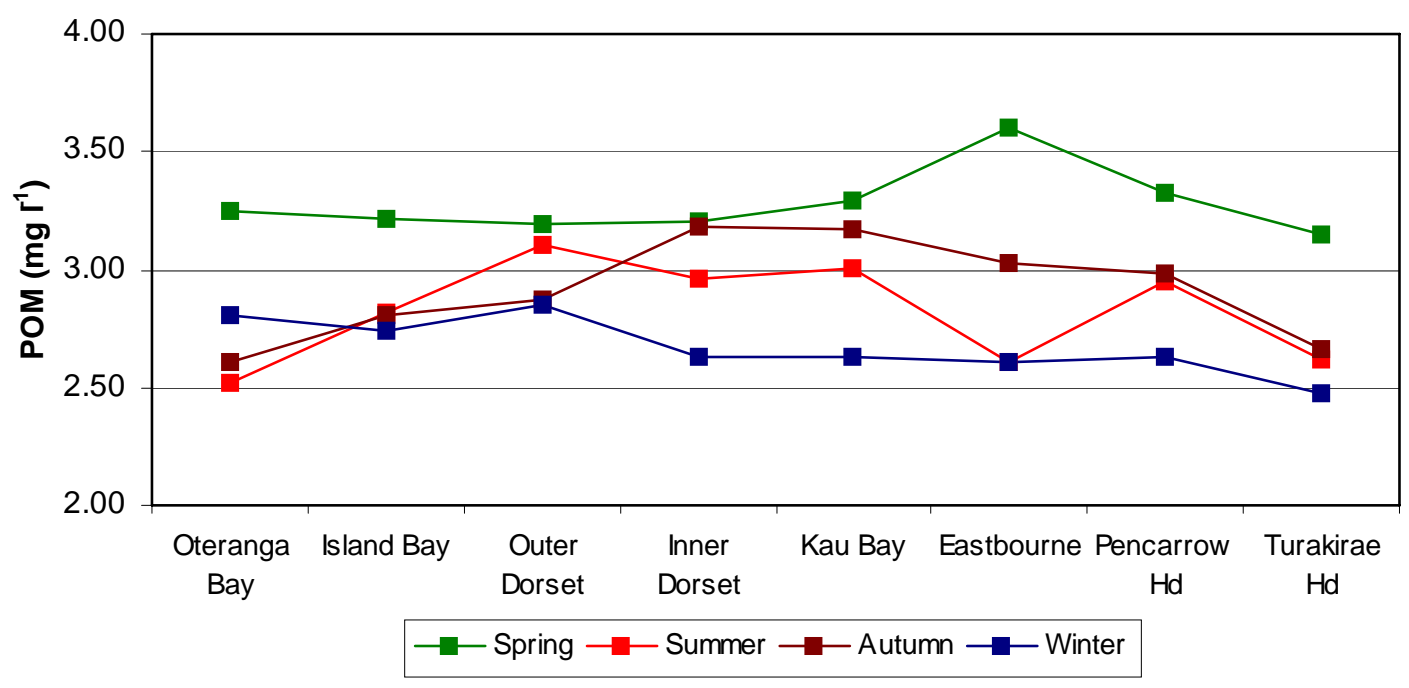

Figure 2.6. Mean seasonal variation in particulate organic matter (POM).

Table 2.2. Mean ( \pm SD) of temperature, salinity, dissolved oxygen, TPM and POM form water samples collected from all sites from September 1998-January 2000.

\begin{tabular}{l|ccccc}
\hline & $\begin{array}{c}\text { Temperature } \\
\left({ }^{\circ} \mathrm{C}\right)\end{array}$ & $\begin{array}{c}\text { Salinity } \\
(\mathrm{ppt})\end{array}$ & $\begin{array}{c}\text { Dissolved } \\
\text { Oxygen (\%) }\end{array}$ & $\begin{array}{c}\text { Total } \\
\text { Particulate } \\
\text { Matter }\left(\mathrm{mg} \mathrm{l}^{-1}\right)\end{array}$ & $\begin{array}{c}\text { Particulate } \\
\text { Organic Matter } \\
\left(\mathrm{mg} \mathrm{l}^{-1}\right)\end{array}$ \\
\hline Oteranga Bay & $14.2(1.5)$ & $35.0(0.3)$ & $95.3(5.3)$ & $13.3(2.0)$ & $2.8(0.6)$ \\
Island Bay & $14.5(1.7)$ & $34.9(0.3)$ & $96.8(4.0)$ & $13.6(3.2)$ & $3.0(0.7)$ \\
Outer Dorset & $14.6(2.0)$ & $34.0(0.6)$ & $98.6(13.3)$ & $13.4(2.1)$ & $3.0(0.6)$ \\
Inner Dorset & $14.7(2.2)$ & $34.2(0.7)$ & $96.4(14.4)$ & $13.1(1.0)$ & $3.1(0.7)$ \\
Kau Bay & $14.8(2.6)$ & $33.8(0.7)$ & $95.7(15.2)$ & $12.6(0.9)$ & $3.1(0.7)$ \\
Eastbourne & $15.1(3.0)$ & $32.6(1.8)$ & $96.5(15.7)$ & $13.2(3.0)$ & $3.1(0.8)$ \\
Pencarrow Hd & $14.4(1.8)$ & $34.3(0.5)$ & $97.8(9.9)$ & $13.6(2.0)$ & $3.1(0.8)$ \\
Turakirae Hd & $14.4(1.7)$ & $34.7(0.3)$ & $96.6(5.5)$ & $13.2(1.8)$ & $2.8(0.8)$ \\
\hline
\end{tabular}

Percent organic matter (PCOM) was generally higher inside the Harbour than at Coastal sites (Fig. 2.7 \& Table 2.3). Variation in PCOM was highest at Harbour sites (e.g. Eastbourne 11.8-35.1\%). Table 2.3 shows variation in PCOM at western Coastal sites (e.g. Oteranga Bay 15.1-26.8\%) was less than those to the east (e.g. Turakirae 10.25-31.3\%). The highest values at all sites were recorded in the spring and autumn months (Fig. 2.7 \& Appendix A6). An ANOVA detected significant differences in PCOM among all sites and between grouped sites (Table 2.3). 


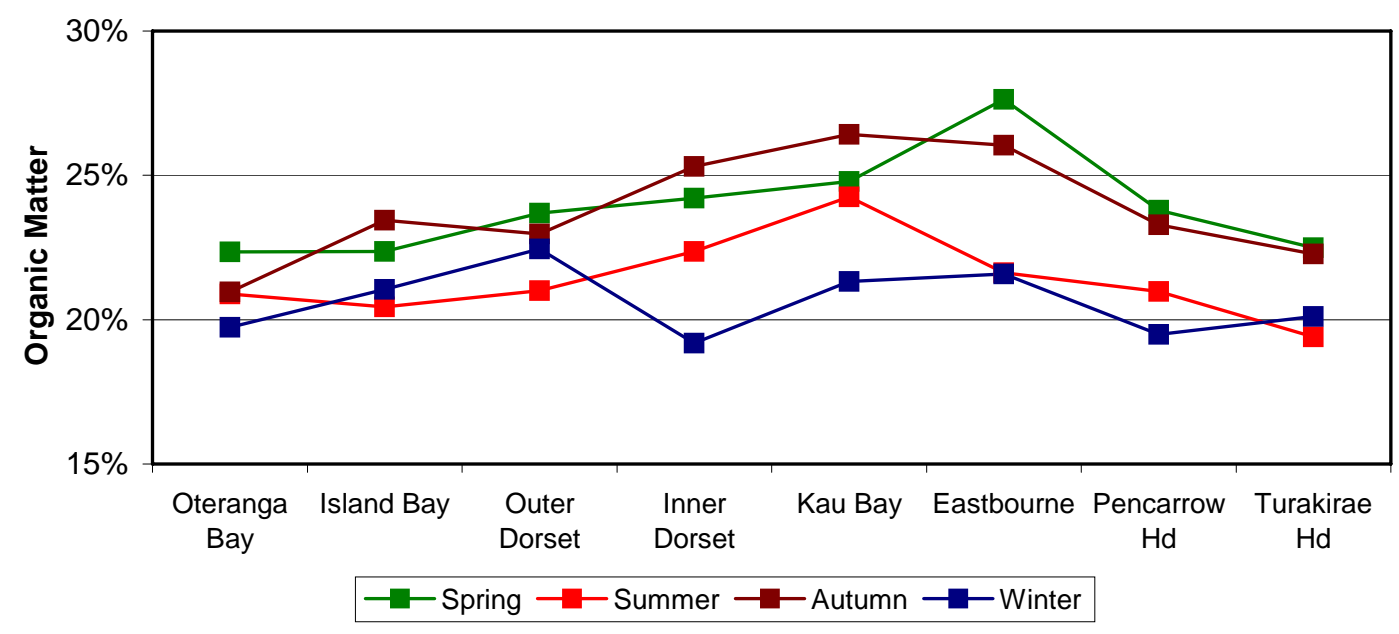

Figure 2.7. Mean seasonal variation in percent organic matter (PCOM).

Concentrations of chlorophyll $a$ were far greater at sites inside the Harbour compared to those on the Coast (Fig. 2.8 \& Table 2.3). Chlorophyll $a$ concentration was greater in the Harbour at all times of the year, although the difference was less pronounced in the winter months. The range of variation between seasons was also greater at Harbour sites; Inner Dorset ranged from 0.16-0.65 $\mu \mathrm{g} \mathrm{l}^{-1}$, while Oteranga Bay ranged from 0.06-0.12 $\mu \mathrm{g} \mathrm{l}^{-1}$ (Fig. 2.8 \& Appendix A7). A significant difference was evident from ANOVA among all sites and grouped sites (Table 2.4).

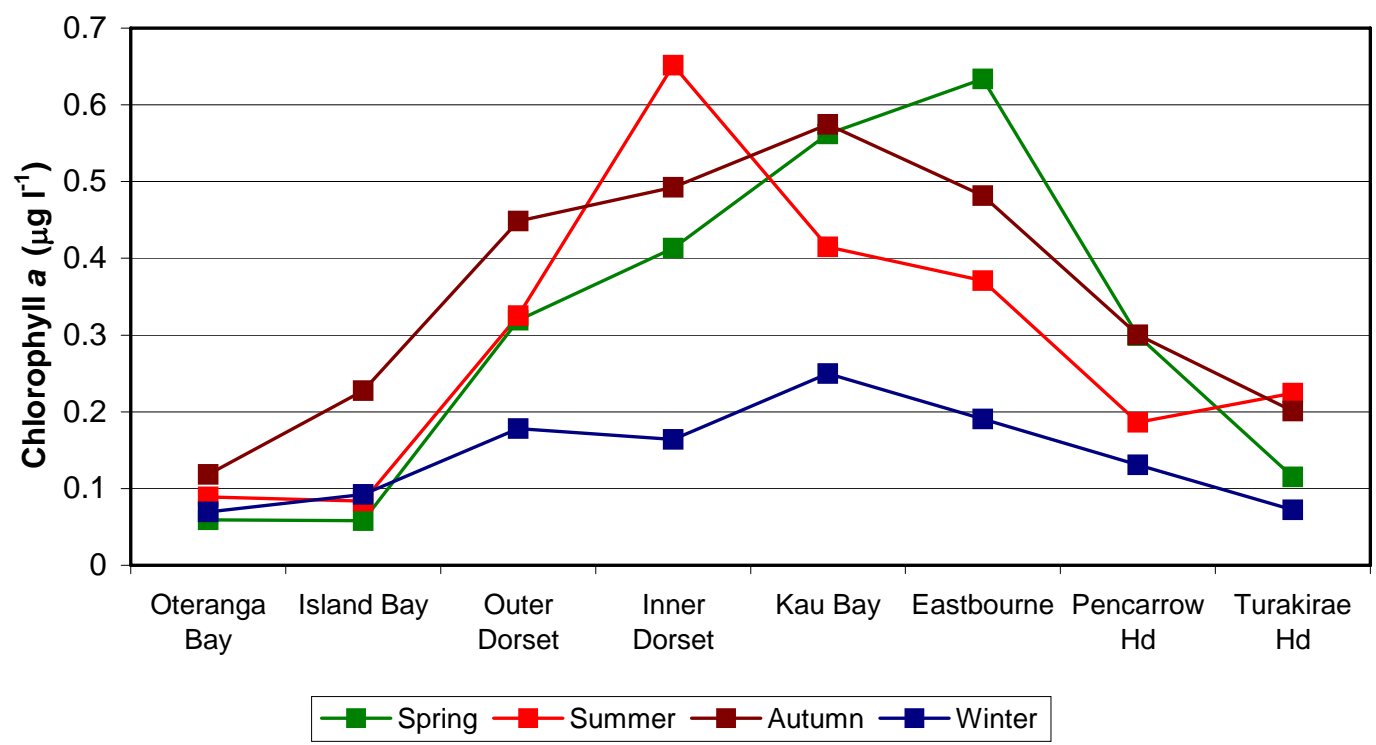

Figure 2.8. Mean seasonal variation in chlorophyll $a$. 
Particle counts $(2.5-63.0 \mu \mathrm{m})$ were higher at Harbour sites than at Coastal sites (Fig. 2.9). The seasonal variation was greater at Harbour sites (Eastbourne, 15589-41775 particles $\mathrm{ml}^{-1}$ ) compared to Coastal sites (Oteranga Bay, 8525-12375 particles $\mathrm{ml}^{-1}$ ) (Table 2.3). Counts were higher at all sites in summer and spring (Fig. 2.9 \& Appendix A8). A non-parametric Kruskall-Wallis analysis found differences in particle count were significant among all sites and between grouped sites (Table 2.6).

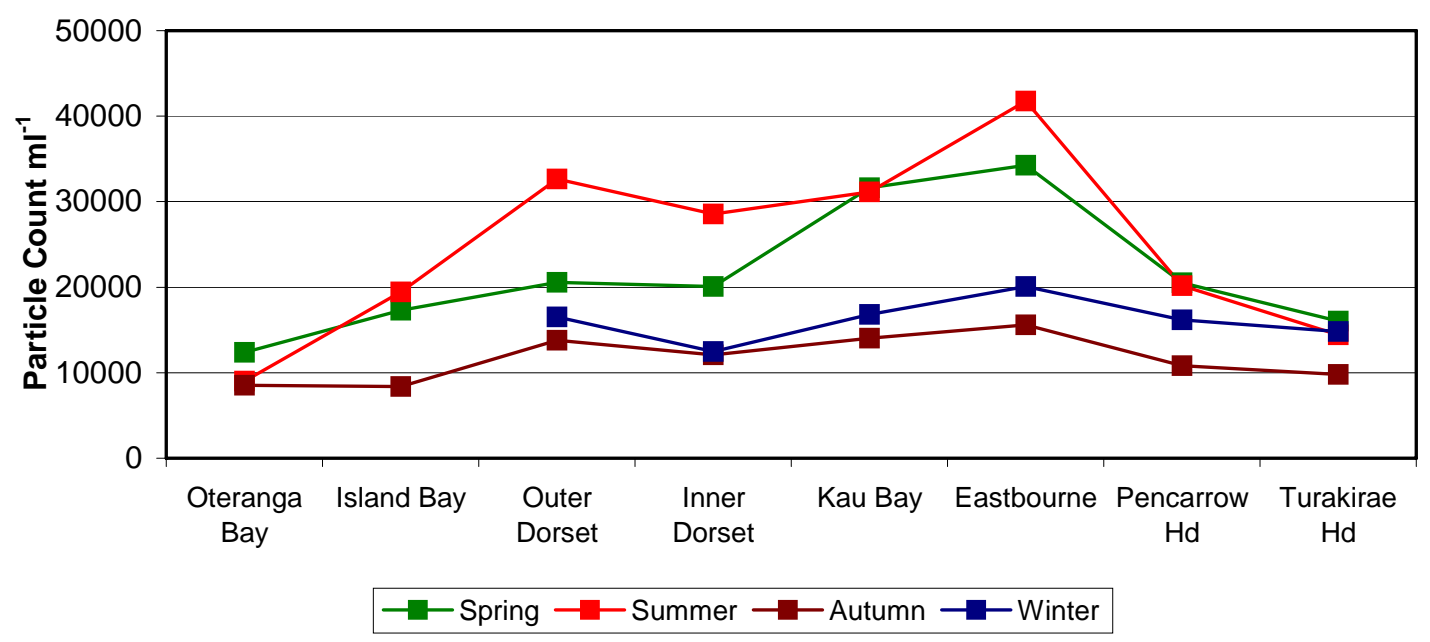

Figure 2.9. Mean seasonal variation in particle count $(2.5-63.0 \mu \mathrm{m})$.

The ratio of carbon to nitrogen $(\mathrm{C}: \mathrm{N})$ ranged between 5-7 and was relatively constant across all sites both inside and outside the Harbour (Fig. 2.10 \& Table 2.3). There was also very little evidence of variation in C:N ratio with season (Fig. 2.10). At each site, seasonal variation was also very similar (Fig. 2.10 \& Appendix A9). A nonparametric Kruskall-Wallis test did not show significant differences in C:N among all sites or between grouped sites (Table 2.6)

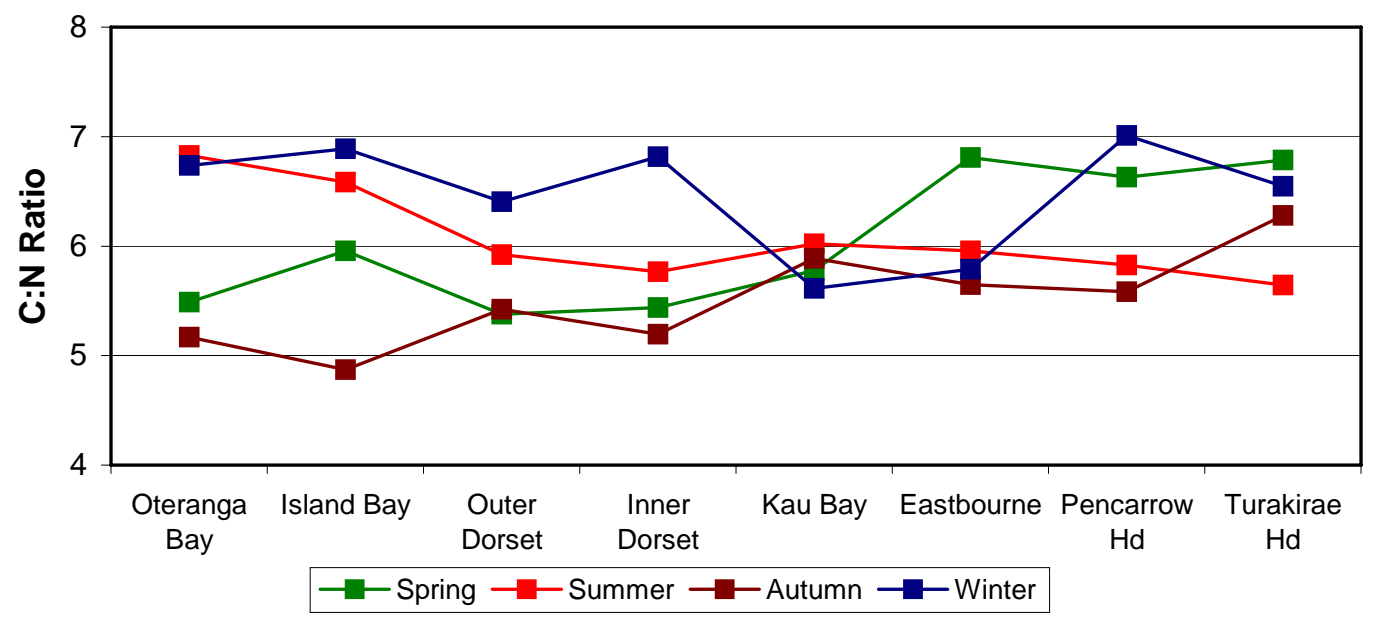

Figure 2.10. Mean seasonal variation in ratio of carbon to nitrogen. 
Percent carbon (\%C) was generally greater at Harbour sites, although during the winter months there is little difference among sites (Fig. 2.11 \& Table 2.3). Percent carbon was particularly high in spring at Harbour sites when it was 2-3 times higher than at Coastal sites. The seasonal range of \%C at Harbour sites was greater than Coastal sites, with Kau Bay ranging from 9.94-24.9 \%C and Island Bay ranging from 4.49-12.55 \%C (Fig. 2.11 \& Appendix A10). A non-parametric Kruskall-Wallis test found differences in \%C to be significant among all sites and between grouped sites (Table 2.6).

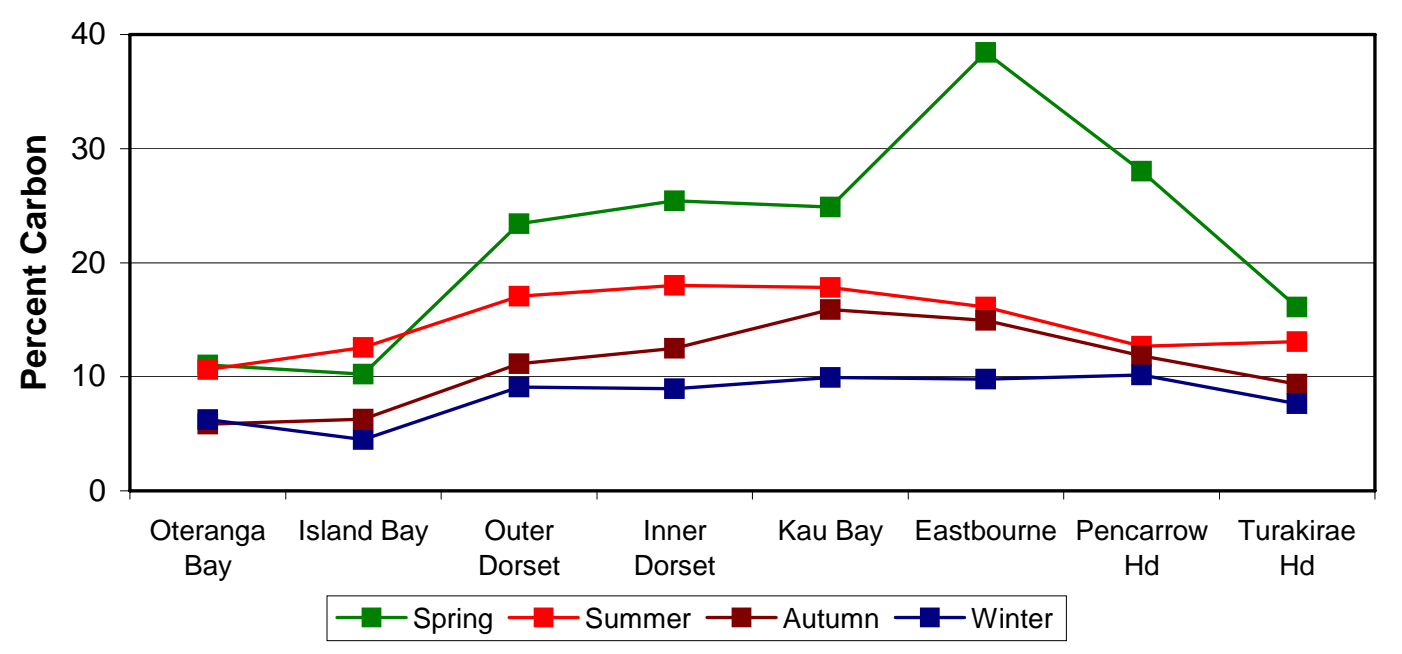

Figure 2.11. Mean seasonal variation in percent carbon.

As with carbon, percent nitrogen $(\% \mathrm{~N})$ was generally greater at Harbour sites, although this is less so in the winter months (Fig. 2.12 \& Table 2.3). This trend was particularly strong in spring when percent nitrogen at Harbour sites was 2-3 times higher than at Coastal sites. The seasonal range of $\% \mathrm{~N}$ at Harbour sites was greater than Coastal sites, with Inner Dorset ranging from 1.35-4.74 \%N and Turakirae Head ranging from 1.17-2.50 \%N (Fig. 2.12 \& Appendix A11). A non-parametric KruskallWallis test found differences in $\% \mathrm{~N}$ to be significant among all sites and between grouped sites (Table 2.6). 


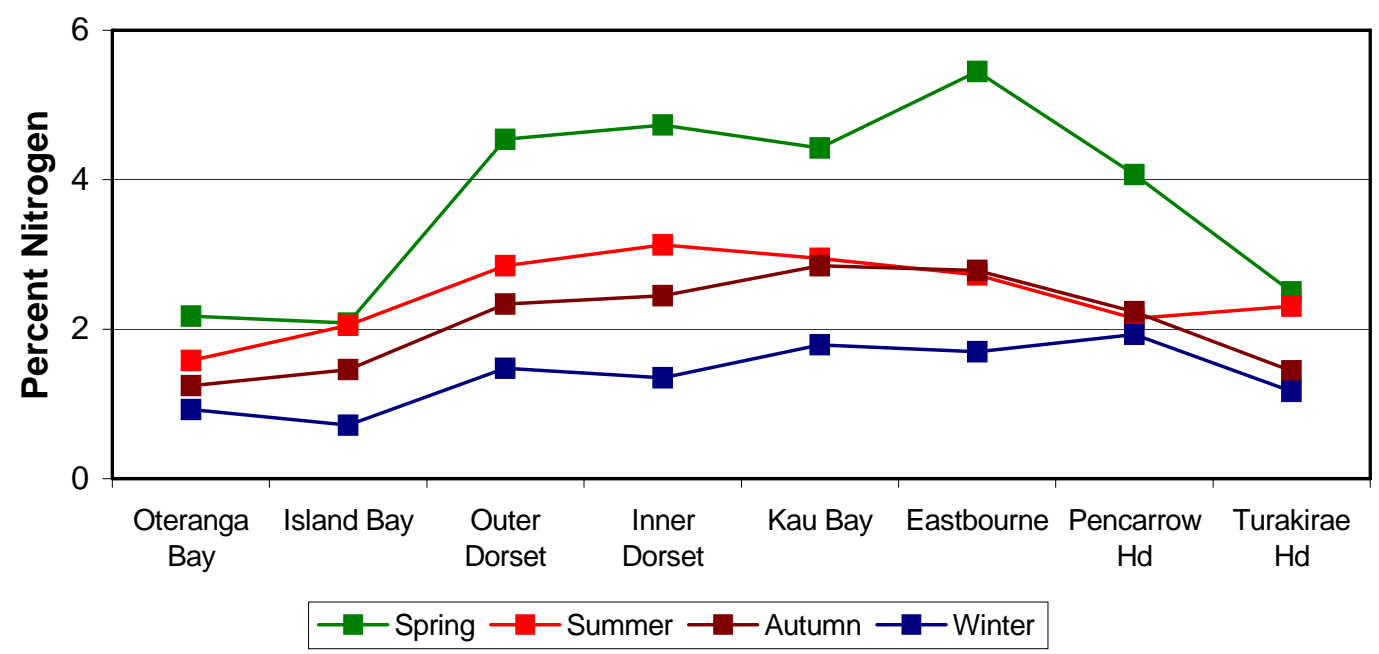

Figure 2.12. Mean seasonal variation in percent nitrogen.

Table 2.3. Mean ( \pm SD) of percent organic matter (PCOM), chloropyhll $a$, particle count, C:N ratio, percent $\mathrm{C}$ and percent $\mathrm{N}$ from water samples collected from all sites from September 1998-January 2000.

\begin{tabular}{|c|c|c|c|c|c|c|}
\hline & $\begin{array}{c}\text { Organic } \\
\text { Matter } \\
(\%)\end{array}$ & $\begin{array}{c}\text { Chlorophyll } \\
a\left(\mu \mathrm{g} \mathrm{l}^{-1}\right)\end{array}$ & $\begin{array}{l}\text { Particle Count } \\
\quad\left(\text { no. } \mathrm{ml}^{-1}\right)\end{array}$ & $\mathrm{C}: \mathrm{N}$ ratio & $\begin{array}{l}\text { Percent } \\
\text { Carbon }\end{array}$ & $\begin{array}{l}\text { Percent } \\
\text { Nitrogen }\end{array}$ \\
\hline Oteranga Bay & $21.3(3.1)$ & $0.08(0.04)$ & 9932 (3605) & $5.68(1.27)$ & $9.01(2.64)$ & $1.76(0.76)$ \\
\hline Island Bay & $22.0(4.3)$ & $0.11(0.09)$ & 14104 (11380) & $6.34(1.98)$ & $9.02(3.42)$ & 1.87 (1.09) \\
\hline Outer Dorset & $22.8(4.0)$ & $0.33(0.14)$ & 19509 (9638) & $5.49(0.83)$ & $18.3(7.16)$ & 3.49 (1.60) \\
\hline Inner Dorset & $23.4(5.2)$ & $0.45(0.25)$ & 17723 (7179) & $5.35(0.73)$ & $19.4(7.00)$ & 3.73 (1.44) \\
\hline Kau Bay & 24.6 (4.9) & $0.48(0.21)$ & 23656 (10390) & $5.70(0.95)$ & 20.3 (5.91) & 3.66 (0.93) \\
\hline Eastbourne & 25.1 (5.9) & $0.46(0.30)$ & 27138 (12361) & $6.41(1.72)$ & 30.7 (21.2) & $4.56(2.16)$ \\
\hline Pencarrow Hd & $22.5(5.1)$ & $0.25(0.12)$ & $16399(7985)$ & $6.05(1.18)$ & $18(9.49)$ & 3.09 (1.48) \\
\hline Turakirae Hd & $21.5(5.1)$ & $0.15(0.09)$ & 13059 (6093) & $6.80(1.75)$ & $12.6(3.88)$ & $1.93(0.61)$ \\
\hline
\end{tabular}

\section{Statistical Results}

Multivariate ANOVA showed a significant difference among separate sites and grouped sites as shown by the Wilks' Lambda statistics in Table 2.4. As the multivariate analyses showed significant differences among sites for both ungrouped and grouped data, evidence of protection from experiment-wise error rates exists and separate ANOVA are therefore acceptable. The univariate statistics generated by the multivariate tests are also given in Table 2.4. These tests show that only chlorophyll $a$ and percent organic matter were significantly different among the eight sites. However, when sites are grouped into Harbour and Coastal sites, all variables, with the exception of particulate organic matter, are significantly different between the Harbour and Coastal groups (Table 2.4). In all cases where significant differences occur, values at Harbour sites are greater than at Coastal sites. 
Table 2.4. Results of mutlivariate and univariate ANOVAs, testing for differences among ungrouped sites (7 d.f.) and between grouped sites (Harbour v Coast, 1 d.f.).

\begin{tabular}{|c|c|c|c|c|c|c|c|c|}
\hline & \multicolumn{4}{|c|}{ Ungrouped site data } & \multicolumn{4}{|c|}{ Grouped site data } \\
\hline & $\begin{array}{l}\text { Sum of } \\
\text { Squares }\end{array}$ & $\begin{array}{c}\text { Mean } \\
\text { Square }\end{array}$ & $\begin{array}{c}\mathrm{F} \\
\text { Value }\end{array}$ & $\begin{array}{c}\mathrm{p} \\
\text { value }\end{array}$ & $\begin{array}{l}\text { Sum of } \\
\text { Squares }\end{array}$ & $\begin{array}{c}\text { Mean } \\
\text { Square }\end{array}$ & $\begin{array}{c}\text { F } \\
\text { value }\end{array}$ & $\begin{array}{c}\mathrm{p} \\
\text { value }\end{array}$ \\
\hline Multivariate & & & & & & & & \\
\hline $\begin{array}{l}\text { Wilks’ Lambda } \\
\text { Univariate }\end{array}$ & & & 7.052 & $<0.001$ & & & 31.302 & $<0.001$ \\
\hline Temperature & 54.842 & 7.835 & 1.839 & 0.078 & 36.320 & 36.320 & 8.561 & 0.004 \\
\hline ТРM & $<0.001$ & $<0.001$ & 1.816 & 0.082 & $<0.001$ & $<0.001$ & 8.885 & 0.003 \\
\hline POM & $<0.001$ & $<0.001$ & 0.740 & 0.638 & $<0.001$ & $<0.001$ & 2.341 & 0.127 \\
\hline PCOM & 0.049 & 0.007 & 2.641 & 0.011 & 0.038 & 0.038 & 14.547 & $<0.001$ \\
\hline Chl $a$ & 9.575 & 1.368 & 33.118 & $<0.001$ & 6.409 & 6.409 & 132.97 & $<0.001$ \\
\hline
\end{tabular}

The F-values of the multivariate tests increase from 7.052 to 31.302 when the data are grouped indicating a greater difference between Harbour and Coastal regions than among all eight sites when analysed separately. The difference in the univariate test statistics between the grouped data and the ungrouped data, suggest that a gradient exists between sites that is partially eliminated when sites are grouped together. A multivariate ANOVA was also conducted on these factors to test for differences among sampling times (Table 2.5). As expected there are significant differences in all variables among sampling times (this is also seen in the seasonal variations in graphs in Appendix A).

Table 2.5. Results of a mutlivariate and univariate ANOVAs testing for differences among sampling times (20 d.f.).

\begin{tabular}{l|cccc}
\hline & Sum of Squares & Mean Square & $\begin{array}{c}\mathrm{F} \\
\text { value }\end{array}$ & $\begin{array}{c}\mathrm{p} \\
\text { value }\end{array}$ \\
\hline $\begin{array}{l}\text { Multivariate } \\
\text { Wilks' Lambda }\end{array}$ & & & & \\
Univariate & & & 22.687 & $<0.001$ \\
Temperature & 1512.0 & 75.601 & 95.783 & $<0.001$ \\
TPM & 0.001 & $<0.001$ & 15.595 & $<0.001$ \\
POM & $<0.001$ & $<0.001$ & 27.902 & $<0.001$ \\
PCOM & 0.723 & 0.036 & 33.570 & $<0.001$ \\
Chl $a$ & 4.848 & 0.242 & 44.461 & $<0.001$ \\
\hline
\end{tabular}

Kruskal-Wallis tests on each variable showed significant differences existed among sites for salinity, dissolved oxygen, percent organic matter, particle count, percent carbon, percent nitrogen and chlorophyll $a$. When data were grouped together into Harbour and Coastal sites two changes occurred, dissolved oxygen was no longer significant and the difference in particulate organic matter is significant (Table 2.6). In cases where significant differences occur, Harbour values are greater than Coastal values with the exception of salinity. 
Table 2.6. Results of Kruskal-Wallis tests on all variables against site for ungrouped and grouped data.

\begin{tabular}{l|ccc|ccc}
\hline \multirow{2}{*}{$\begin{array}{c}\text { Measured } \\
\text { Variable }\end{array}$} & \multicolumn{3}{|c|}{ Ungrouped site data } & \multicolumn{3}{c}{ Grouped site data } \\
\cline { 2 - 7 } & $\begin{array}{c}\text { Kruskal-Wallis } \\
\text { test statistic }\end{array}$ & p-value & $\mathrm{n}$ & $\begin{array}{c}\text { Mann-Whitney } \\
\text { U test statistic }\end{array}$ & p-value & $\mathrm{n}$ \\
\hline Temperature & 3.819 & 0.800 & 459 & 22761.00 & 0.112 & 459 \\
Salinity & 198.654 & $<0.001$ & 348 & 23863.50 & $<0.001$ & 348 \\
Dissolved Oxygen & 14.179 & 0.048 & 240 & 5868.00 & 0.065 & 240 \\
TPM & 13.776 & 0.055 & 469 & 28389.50 & 0.073 & 469 \\
POM & 11.577 & 0.115 & 469 & 22521.50 & 0.020 & 469 \\
PCOM & 31.864 & $<0.001$ & 469 & 18831.00 & $<0.001$ & 469 \\
Particle Count & 83.835 & $<0.001$ & 291 & 5197.00 & $<0.001$ & 291 \\
C:N ratio & 12.610 & 0.082 & 342 & 13713.00 & 0.904 & 342 \\
Percent Carbon & 124.026 & $<0.001$ & 344 & 7321.00 & $<0.001$ & 344 \\
Percent Nitrogen & 106.447 & $<0.001$ & 345 & 7547.50 & $<0.001$ & 345 \\
Chlorophyll $a$ & 242.863 & $<0.001$ & 447 & 7984.00 & $<0.001$ & 447 \\
\hline
\end{tabular}

\subsection{Discussion}

Significant differences were detected in many of the water quality parameters tested in this study. Harbour water has generally higher levels of chlorophyll $a$, number of particles and percent nitrogen and carbon. This is most likely to be due to the difference in hydrography between the Harbour and the South Coast. Cook Strait water is derived from swiftly moving oligotrophic currents (Chapter One). This allows little time for them to be influenced by coastal topography or nutrients and particulate material associated with freshwater input. Wellington Harbour however, is relatively shallow (mean $\approx 20 \mathrm{~m}$ ), has high freshwater input and a flushing time of $\approx 10$ d (Chapter One). Input from the Hutt River will also cause a degree of eutrophication because much of the catchment is rural and suburban. Major riparian input to the South Coast is limited to the Orongorongo and Wainuiomata Rivers (east of Wellington Harbour) and a few small streams (pers. obs.). The Orongorongo River catchment is covered in native bush and therefore would not have the same high nutrient input. However, the catchment of the Wainuiomata River is a mixture of native bush and significant suburban and rural land use and, although much smaller than the Orongorongo River catchment, may contribute significant nutrients to the immediate Coastal environment. Generally however, higher levels of percent $\mathrm{C}$ and $\mathrm{N}$ at Harbour sites corroborate this difference in nutrient and particulate concentration between Harbour and Coastal sites. These factors combine to promote enrichment of Harbour water, while at the South Coast, nutrient-poor water ebbs and flows constantly from the oceanic currents that supply Cook Strait. Booth (1975) concluded 
that Wellington Harbour is cut off from Cook Strait to a greater extent then had been suggested by earlier authors (Maxwell, 1956; Gilmour, 1960), this contention is supported by the findings of the present research.

My values of temperature and salinity in Wellington Harbour are almost identical to those of Booth (1975). Booth (1975) reported mean summer and winter temperatures in the Harbour of 17.2 and $11.2^{\circ} \mathrm{C}$ respectively compared to 17.6 and $11.8^{\circ} \mathrm{C}$ in my study. Daily sea surface temperatures recorded at the National Institute of Water and Atmospheric Research aquaculture facility at Mahanga Bay compared well with those recorded in this study from Kau Bay. The mean difference between the two sites was $0.49^{\circ} \mathrm{C}$ for a comparison among 20 observations. Salinity in Wellington Harbour was reported by Booth (1975) to range between 33.5-34.5\%o under normal freshwater discharge, approximately 1\%o lower than Cook Strait. My mean salinity value for Harbour sites was 33.5\% under all conditions, and my mean value for salinity in Cook Strait was 34.6\%o. Harbour waters tended to be warmer in summer and cooler in winter compared to the South Coast. Salinity was higher at Coastal sites and more stable over time, especially when compared to Harbour sites in close proximity to the Hutt River where salinity was observed to decrease to as low as 28\% at Eastbourne, and has been recorded at this location as low as 18.9\% (Gardner \& Kathiravetpillai, 1997).

Levels of total particulate matter (TPM) were consistent with published values at both Coastal and Harbour sites. Observations of TPM in the literature generally range between 8 and $15 \mathrm{mg} \mathrm{l}^{-1}$ in temperate waters (Berry \& Schleyer, 1983; Bayne et al., 1984; Page \& Ricard, 1990; Navarro et al., 1992; Okumu• \& Sterling, 1994; Gardner, 2000). However, observations made by Gardner and Thompson (2001) of TPM at Island Bay in February 1996, were much lower (mean $3.8 \mathrm{mg} \mathrm{l}^{-1}$ ) than those found in this study at Island Bay in the summer (mean $13.8 \mathrm{mg} \mathrm{l}^{-1}$ ). This suggests a high degree of temporal variation in TPM at Coastal sites, probably caused by resuspension of material at times of unsettled weather. The lowest variation in TPM occurred at Harbour sites with the exception of Eastbourne. High variation in TPM at Eastbourne is due to the influence of terrigenous output from the nearby Hutt River. 
Observations of percent organic matter (PCOM) were generally lower at Coastal sites than at Harbour sites. At Coastal sites, variation in PCOM was lower at western sites and higher to the east. This may be a result of nutrient-rich water leaving the Harbour and being transported to the eastern Coastal sites by the prevailing eastward moving Cook Strait currents (Heath, 1971). Similar levels of POM were observed at Harbour and Coastal sites, variation of POM within sites was also very similar. Levels of POM at IBML were very close to those reported by Gardner (2000) in both summer and winter. However, at Mahanga Bay (adjacent to Kau Bay), Gardner (2000) reported an increase in POM from $4.0 \mathrm{mg} \mathrm{l}^{-1}( \pm 1.1, \mathrm{n}=30)$ in summer to $7.0 \mathrm{mg} \mathrm{l}^{-1}( \pm 1.1, \mathrm{n}=15)$ in winter. In my study, mean POM in summer at Kau Bay was $3.01 \mathrm{mg} \mathrm{l}^{-1}( \pm 0.64, \mathrm{n}=4)$ and $2.63 \mathrm{mg} \mathrm{l}^{-1}( \pm 0.90, \mathrm{n}=3)$ in winter. The data recorded at IBML were considerably higher than those observed by Gardner and Thompson (2001) in February 1996 (0.86$\left.1.04 \mathrm{mg} \mathrm{l}^{-1}\right)$. At IBML and Kau Bay, PCOM values were similar ( $\left.\approx 21 \%\right)$, Gardner (2000) found values of $30.1( \pm 2.31, \mathrm{n}=30)$ and $21.5( \pm 2.66, \mathrm{n}=15)$ at IBML in summer and winter respectively. In my study, summer values $(21.04 \pm 7.03, \mathrm{n}=3)$ at IBML were similar to those in winter $(\approx 20.4 \pm 2.84, \mathrm{n}=5)$. Gardner and Thompson (2001) reported a range of PCOM in summer at IBML of 20.77-26.05. Gardner (2000) reported very high values of PCOM $(59.17 \pm 6.44)$ at Mahanga Bay in winter, although such high concentrations were not observed in this study. Values in this study are low compared to published data. Published values of PCOM generally range between 25-60\% in temperate coastal systems (Berry \& Schleyer, 1983; Bayne et al., 1984; Page \& Ricard, 1990; Navarro et al., 1991; Okumu• \& Sterling, 1994; Gardner, 2000).

The most dramatic differences between Harbour and Coastal sites were observed in concentrations of chlorophyll $a$. Concentrations at Coastal sites were usually between 0.1-0.3 $\mu \mathrm{g} \mathrm{l}^{-1}$; these are low compared with published data. Gibbs et al. (1992) and Gibbs and Vant (1998) assert that sites associated with mussel culture in New Zealand generally have chlorophyll $a$ values ranging between 1 and $5 \mu \mathrm{g} \mathrm{l^{-1 }}$. These values are marginally higher than those seen at Harbour sites (0.4-0.7 $\mu \mathrm{g} \mathrm{l}^{-1}$ ) and considerably higher than values recorded at Coastal sites. Very low levels of chlorophyll $a$ ( $<1 \mu \mathrm{g}$ $\mathrm{l}^{-1}$ ) were also observed by James et al. (2001) at Beatrix Bay, Marlborough Sounds, New Zealand. Hickman et al. (1991) observed high variability in chlorophyll $a$ at sites within the Marlborough Sounds. Values ranged from 0.3-3.2 $\mu \mathrm{g} \mathrm{l^{-1 }}$ with most 
observations between 1.0 and $2.0 \mu \mathrm{g} \mathrm{l}^{-1}$ at most sites (Hickman et al., 1991). Ogilvie et al. (2000) also observed levels of chlorophyll $a$ similar to those of Hickman et al. (1991) at farms in Beatrix Bay. Chlorophyll $a$ concentrations have a direct effect on the condition of $P$. canaliculus. Hawkins et al. (1999) found that tissue wasting occurred when $P$. canaliculus of $1 \mathrm{~g}$ dry tissue weight was fed on seston with chlorophyll $a$ concentrations of less than $0.86 \pm 0.19 \mu \mathrm{g} \mathrm{l}^{-1}$. Water samples from

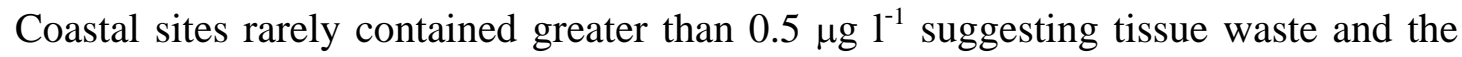
mussel's inevitable death. At Harbour sites however, while chlorophyll $a$ values were on average considerably higher than at Coastal sites, they did not often exceed $0.86 \mu \mathrm{g} \mathrm{l^{-1 }}$.

Ratios of particulate C:N at Harbour and Coastal sites ranged between 5-7, and were similar to those found by James et al. (2001) in the Marlborough Sounds and Gardner and Thompson (2001) at Island Bay in the summer of 1996. C:N ratios of $<8$ are characteristic of recent primary production from a marine source, ratios $>8$ however, generally correspond to older primary production or terrestrial input (Gardner, pers. comm., James et al., 2001). Although no appreciable difference in C:N ratio was observed between Harbour and Coastal sites, percent nitrogen and carbon did vary between the Harbour and South Coast. Harbour sites had percent $\mathrm{C}$ and N values 2-3 times greater than Coastal sites. This is most likely due to terrestrial based eutrophication from the Hutt River and other urban runoff. As with chlorophyll $a$, a threshold level of particulate organic carbon (POC) has been identified at $200 \mu \mathrm{g} \mathrm{C} \mathrm{l}^{-1}$, below which tissue wasting occurs (Hickman, et al., 1991). Unfortunately, no comparison with Hickman et al. (1991) can be made as POC data were not collected in my study.

A comparison of water characteristics between Island Bay and eastern Coastal sites indicate only slight differences in most of the measured parameters. However, while mussels are completely absent from Island Bay shores, they do occur in small numbers at eastern Coastal sites such as Pencarrow Head and adjacent bays. This apparent anomaly assumes that mussels are responding to those parameters that are being measured, although no causal relationship has been demonstrated, mussels may be responding to a complex combination of characteristics or several unmeasured parameters for which the observations are merely surrogates (Hawkins et al., 1999). 
In conclusion, Harbour sites tend to be comparatively nutrient rich and much more temporally variable compared to Coastal sites. Data from Harbour sites tend to agree reasonably closely with other temperate systems, however, Coastal sites had generally lower concentrations of PCOM and chlorophyll $a$ which indicate lower water quality (Berry \& Schleyer, 1983; Bayne et al., 1984; Page \& Ricard, 1990; Navarro et al., 1992; Okumu • \& Sterling, 1994). Wellington Harbour is a relatively small body of water compared to Cook Strait and meteorological conditions and terrigenous inputs are therefore far more influential. These data support the assertion by Booth (1975) that the two systems are at least partially isolated from each other. 


\section{CHAPTER THREE}

\section{Planktonic Larvae and Settlement}

\subsection{Introduction}

Mussels are typically broadcast spawners with external fertilisation, and have a planktonic larval phase. This enables mussel populations to colonise wide areas of coastal rocky habitat and allows for gene flow between populations. This begins with external fertilisation and a ciliated trochophore stage is reached within 24-48 h (Lutz \& Kennish, 1992). The first larval shell, prodissoconch I, is secreted shortly after the trochophore stage. At this stage, larvae are commonly $100-120 \mu \mathrm{m}$ in length and known as "D-shape” because of the anterior flat-hinged area and the posterior ventral margin (Sprung, 1984). A second major growth stage follows, in which the prodissoconch II shell is secreted. This stage can last for several weeks (Sprung, 1984) and larvae grow rapidly to approximately $250 \mu \mathrm{m}$ (Seed \& Suchanek, 1992). This stage is more commonly termed the veliger stage and typically lasts from 1-4 wk (Lutz \& Kennish, 1992), during which time the larvae feed actively in the water column. Toward the end of the veliger stage the foot begins to develop and larvae are known as pediveligers. At this stage, if conditions are favourable, larvae will settle onto substrate and undergo metamorphosis in preparation for a sessile mode of life (Lutz \& Kennish, 1992).

The absence of mussel larvae in the plankton on the South Coast would certainly be a compelling argument for the absence of adult populations. The blue mussel Mytilus edulis has a planktonic phase of 2-4 wk in temperate waters (Seed \& Suchanek, 1992). Assuming M. galloprovincialis and other mussels from Wellington Harbour spend similar amounts of time as planktonic organisms, this would provide them with ample time to colonise the South Coast. Considering the close proximity of large populations of mussels in both the Harbour and Marlborough Sounds, and the swift movement of Cook Strait waters, it would be expected that larvae would be found at Coastal Sites. If larvae from these populations are being carried too far to supply Coastal areas, then larval supply to the Coast might be expected from the same source 
as that supplying the Marlborough Sounds and Wellington Harbour. It may be however, that the hydrography of Cook Strait is so turbulent that larval density is diminished to the point where not enough larvae remain to establish adult populations. However, this is unlikely given the distribution of mussels in very exposed areas in other parts of the world (Paine, 1974).

If we assume that larvae are present at Coastal sites, it may be that conditions are not suitable for mussel settlement. Various factors have been isolated as being important for the successful development of $M$. edulis. These include environmental factors, most importantly temperature, adequate food supply, level of predation, avoiding accidental ingestion by other filter feeders, and access to favourable settlement substrate (Paine, 1974; Lutz \& Kennish, 1992). Should larvae 'choose' not to settle on substrates it might be that some or all of these factors are acting to prevent settlement or some other stimulus is not present. Given the complexity of settlement cues and the poor understanding of the exact requirements for mussel settlement, it would be difficult to say why larvae are not settling (Butman, 1987; Pawlik, 1992). There has for example been some debate as to the relative importance of chemical cues in invertebrate settlement and the exact method for the detection of such compounds in the water column. This is of particular importance for gregarious species like mussels who are known to settle with conspecifics (Pawlik, 1992). While this is an interesting aside, it is outside the scope of this study.

The purpose of this chapter is to quantify the density of mussel larvae in the plankton and the density at which they settle on artificial substrates in both Wellington Harbour and the South Coast. From these data, the extent to which these factors are limiting the establishment of adult mussel populations on Wellington's South Coast will be determined.

\subsection{Materials and Methods}

\section{Mussel Plankton Collection}

Plankton tows were made at one site inside the Harbour (Kau Bay) and two sites on the South Coast (Oteranga Bay and Island Bay) (Fig. 3.1). An attempt was made to sample at monthly intervals, but due to gear failure and adverse weather conditions 
this was not always possible. The sampling gear consisted of a $100 \mu \mathrm{m}$ plankton net that was housed on a metal ring ( $0.7 \mathrm{~m}$ diameter), which was housed inside another

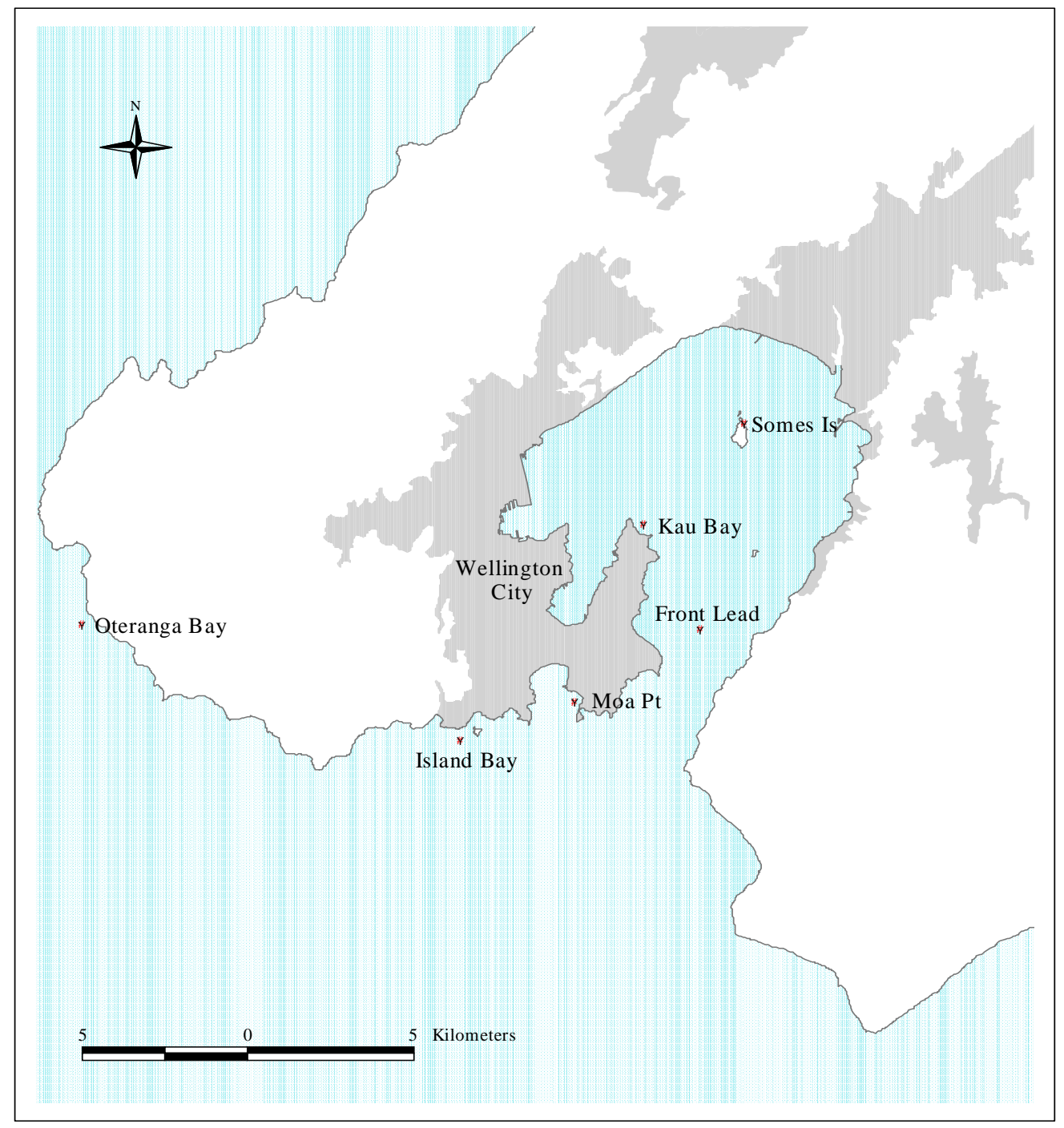

Figure 3.1. Location of sampling sites for plankton tows and settlement pads.

metal ring (1.0 m diameter). The outer ring had a metal square welded on each side on to which a General Oceanics model 20307 flow meter was housed. A second flow meter was housed inside the mouth of the net to record the volume of water filtered and allow the filtration efficiency, $\mathrm{E}_{\mathrm{f}}$, to be estimated.

$$
\mathrm{E}_{\mathrm{f}}=\text { Flow Vol.outside } / \text { Flow Vol.inside }
$$

The flow efficiency, $E_{f}$, is a measure of the degree to which the net became clogged and was unable to filter the water effectively (Tranter \& Smith, 1968). The outer ring was weighted at the bottom and had a float attached to the top to stop the gear 
rotating in the water. This was necessary as when the gear rotated, the flow meter housed outside the net would lift out of the water and stop recording.

On each sampling occasion three replicate tows were made at a depth of 1-2 metres at each site. All tows were conducted from the $R V$ Raukawa Challenger at a speed of $\approx 2$ knots and each was of $\approx 5$ min duration. At this speed the gear worked best, that is, without putting undue strain on the net, while maintaining enough speed for the flow meters to operate constantly. Tow volumes were typically 50-100 $\mathrm{m}^{-3}$, however, net clogging occasionally occurred at Kau Bay because of high phytoplankton concentration, this reduced the volume of some tows to only $10-20 \mathrm{~m}^{-3}$. At the completion of each tow the flow meters were read and the sample was washed into the cod end of the net and then into a jar using an on board pump. Due to the comparatively small volume of water used to wash out the net, contamination was assumed to be negligible. At each site, where possible, the water temperature $( \pm$ $\left.0.1^{\circ} \mathrm{C}\right)$ and salinity $( \pm 0.1 \%$ o) were measured from surface water using a YSI 30 meter. Dissolved oxygen ( \pm 0.1\%) was recorded from surface water using a YSI 55 dissolved oxygen meter.

Each plankton sample was fixed using 2\% formalin and stored for up to 4 wk before counting. Samples were stained using Rose Bengal, which helped distinguish mussel larvae from sand grains and other inorganic material. In the laboratory, samples were homogenised by swirling and inverting the jar. A series of five sub-samples were taken from each of the three replicates and mussel larvae were counted under a microscope. In most instances the sub-samples taken were $5 \mathrm{ml}$, with the exception of some Harbour samples where the high abundance of phytoplankton necessitated $3 \mathrm{ml}$ samples. The mean number of mussel larvae from the five sub-samples was then extrapolated to determine the total in each jar. Mussel veligers were distinguished from other molluscs using morphometric characteristics as described by Booth (1977) and Redfearn et al. (1986). Although this study focuses on three different mussel species, no attempt was made to distinguish the larvae of each species. This was primarily due to the high numbers of larvae present in most samples and the difficulty in distinguishing among species (Booth, 1977). Studies to determine the degree of inter-specific competition among mussels and competition with other invertebrates, while of great interest, is outside the scope of this work. 


\section{Statistical analyses}

A stepwise ANOVA was used to test for differences in mussel larvae among sites and months. All mussel count data were log transformed prior to testing and the assumptions of normal distribution and constant variance associated with this parametric test were not violated. Temperature and salinity were added as covariants and the analysis was repeated. A pairwise analysis was also conducted to test for differences between months within each site. Adjustments were made to compensate for multiple testing by using an experiment-wise error rate ( $\alpha=0.05$ / 135 giving critical $\alpha=0.00037)$. Data were combined across years as multiple data existed at some months and was absent for others.

\section{Mussel Settlement Collections}

Method One. Artificial substrates were initially put out at two Harbour sites and two Coastal sites in May 1998. This was an arbitrary date as it was intended to sample for at least one year. The substrate consisted of 3M Scotchbrite scouring pads which were chosen because of their filamentous nature and strength (McGrath et al., 1994). Four pads were attached to rocks just above the water at low tide at each site. Pads were secured to the rock with cable ties and a two-part epoxy concrete (Fosroc Expocrete) that set hard in sea water as the tidal level rose. A strip of $5 \mathrm{~mm}$ thick plastic was cut and screwed to each side of the pad at the top and bottom, and holes were drilled to allow the attachment of cable ties without them pulling through the pad and it being lost. Pads were initially put in the field in May 1998 and were changed monthly until November 1998. This technique proved to be only moderately successful as wave action would occasionally dislodge the anchor points, especially at Coastal sites. After collection, pads were frozen at $-20^{\circ} \mathrm{C}$, larvae were subsequently counted by putting the pad directly under the microscope and removing larvae as they were encountered. Pads were not conditioned before use as this has been shown to be unnecessary for similar nylon pads (McGrath et al., 1994).

Method Two. Due to small numbers of settling mussels being collected at both Harbour and Coastal sites using Method One, it was decided in September 1999 that a different approach would be taken. Rather than putting pads in the inter-tidal zone, they were put in the sub-tidal. Four new sites were selected, two in the Harbour (Matiu-Somes Island and the Front Lead) and two on the Coast (Island Bay and Moa 
Pt) (Fig. 3.1). Permission was sought from The Department of Conservation and the Wellington Regional Council Harbours Division to attach settlement pads to a wharf pile at Matiu-Somes Island (DoC) and a pile at the Front Lead (WRC) (Fig. 3.1). At both sites a rope collar was tied around the pile and the settlement pads were attached to them with cable ties. At both sites the pads were $\approx 3 \mathrm{~m}$ below chart datum (CD). At the Coastal sites, $20 \mathrm{l}$ buckets of concrete with steel reinforcing wire embedded in the top for attachment points were used to anchor settlement pads. These buckets were placed in relatively sheltered points at two South Coast sites, Moa Point and Island Bay, and were at a level that ensured they were always covered with water. Pads were collected and replaced every month and larvae were counted using the same method as above. The same pads were used as in Method One and these were not conditioned before use (McGrath et al., 1994).

Method Three. It was decided in February 2000 to try using some different settlement surfaces as larval settlement rates had not improved. Those chosen were frayed nylon rope, frayed sisal rope, and shade cloth that had been folded 4-5 times to form a pad 200 x $200 \mathrm{~mm}$. All substrates were tested and it was decided that the shade cloth pads were best because the ropes would tangle too easily and were not robust enough for repeated use. Shade cloth pads were not conditioned before use as this has been shown to be unnecessary for similar nylon pads (McGrath et al., 1994). The sites used were the same as those for Method Two, with three replicates at each site. The experiment ran from February 2000 to February 2001.

The manner in which these pads were processed was altered at this time in an attempt to obtain more mussel spat. Pads were changed after $\approx 30 \mathrm{~d}$ and were then left to soak for $24 \mathrm{~h}$ in a solution of fresh water and $2 \%$ formalin. Each pad was then cleaned with a garden hose at moderate pressure and the water collected in a $20 \mathrm{l}$ bucket. This water was then filtered through a $125 \mu \mathrm{m}$ sieve and the sieve contents transferred to a jar. The sample was treated with a $1 \%$ solution of formalin and Rose Bengal which helped distinguish mussel spat from sand grains and other inorganic material. Each sample was then counted by homogenising the contents of each jar and taking $5 \times 5$ ml subsamples for counting under a microscope. The volume of each jar was recorded and the total from each jar was extrapolated from the five subsamples. 
Only data from the experiment outlined in Method Three are presented and analysed. An ANOVA was used to test for differences in numbers of settled mussels among sites and times of the year. Another ANOVA was conducted to test for differences in settlement density between the combined Harbour sites and combined Coastal sites. Both tests were performed on logged data and assumptions of normality and constant variance were not violated.

\subsection{Results}

\subsubsection{Plankton}

As expected large numbers of mussel larvae were found within the Harbour, and although larvae were also found at both Coastal sites, their densities were lower (Table 3.1).

Table 3.1 Density of mussel larvae $\mathrm{m}^{-3}$ from Harbour (Kau Bay) and Coastal (Oteranga Bay \& Island Bay) sites.

\begin{tabular}{r|cccccc}
\hline & \multicolumn{2}{|c}{ Kau Bay } & \multicolumn{2}{c}{ Island Bay } & \multicolumn{2}{c}{ Oteranga Bay } \\
\hline Date & Mean & SD & Mean & SD & Mean & SD \\
\hline Sept 98 & 4206.6 & 1265.4 & 311.2 & 42.0 & 83.7 & 10.2 \\
Oct 98 & & & & & 60.3 & 3.9 \\
Nov 98 & 1398.0 & 130.7 & 82.9 & 49.2 & & \\
Dec 98 & 3536.0 & 1769.1 & 54.8 & 11.0 & 18.5 & 1.6 \\
Jan 99 & 978.7 & 522.9 & 23.5 & 18.9 & 14.5 & 4.1 \\
Mar 99 & 135.4 & 68.4 & 380.7 & 137.9 & & \\
Apr 99 & 2473.9 & 460.3 & 54.4 & 10.5 & 110.0 & 11.3 \\
May 99 & 237.3 & 293.9 & 50.7 & 7.3 & 150.3 & 34.7 \\
Jun 99 & 62.5 & 25.67 & 206.9 & 43.6 & 220.0 & 36.6 \\
Aug 99 & 71.5 & 6.7 & 93.4 & 8.0 & 120.4 & 7.6 \\
Sept 99 & 64.4 & 9.1 & 77.8 & 8.6 & 105.5 & 16.3 \\
Oct 99 & 21.4 & 13.6 & 18.7 & 6.3 & 50.6 & 11.8 \\
Nov 99 & 1163.8 & 567.5 & 23.0 & 7.9 & 64.1 & 14.8 \\
Jan 00 & 184.7 & 91.4 & 55.5 & 41.0 & 39.6 & 7.1 \\
Feb 00 & 145.6 & 92.1 & 30.4 & 13.20 & 92.8 & 51.3 \\
\hline
\end{tabular}

Larval density at Kau Bay was greater than at either Island Bay or Oteranga Bay (Figs. 3.2 \& 3.3). Larvae were present at Kau Bay and both coastal sites all year round in densities ranging from $\approx 21-4207 \mathrm{~m}^{-3}$ at Kau Bay, $\approx 19-380 \mathrm{~m}^{-3}$ at Island Bay and 15$220 \mathrm{~m}^{-3}$ at Oteranga Bay. At Island Bay larval densities peaked in a similar pattern to those at Kau Bay, although the peaks at Island Bay were a little later than the Harbour sample, and about an order of magnitude less. Larval abundance was 
greatest during spring at Kau Bay and in the summer at Island Bay, but at Oteranga Bay, larval density was highest during the winter.

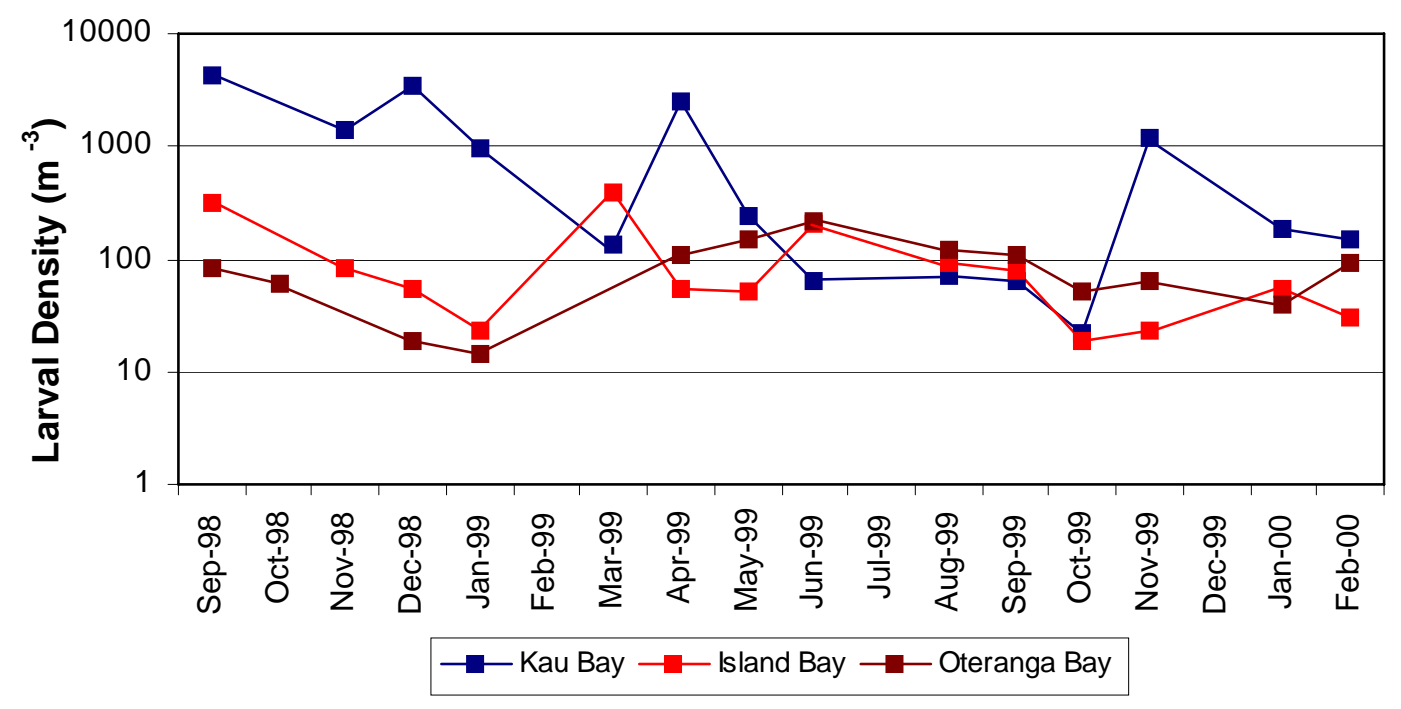

Figure 3.2. Mussel larval density at all sites plotted using a logarithmic y-axis, points are the mean of three samples.

ANOVA testing for differences in larval density among sites and months, revealed both to be significant (whole model: $\mathrm{p}<0.001, \mathrm{~F}=5.253, \mathrm{R}^{2}=0.642, \mathrm{n}=115$ ) as was the site * month interaction (Table 3.2) (Fig. 3.4).

Table 3.2. ANOVA testing for differences in larval density among sites and months.

\begin{tabular}{l|ccc}
\hline \multicolumn{1}{c|}{ Effect } & df & F-value & p-value \\
\hline Site & 2 & 3.398 & 0.038 \\
Month & 9 & 5.478 & $<0.001$ \\
Month * Site & 18 & 3.088 & $<0.001$ \\
\hline
\end{tabular}

A second ANOVA using temperature and salinity data as additional covariants was performed:

$$
\text { LnCount }=\text { Constant }+ \text { Month }+ \text { Site }+ \text { Month*Site }+ \text { Temperature }+ \text { Salinity }
$$

All terms in the above model were significant (Table 3.3) with the exception of Site $(p=0.341)$, although because of the significant site $*$ month interaction this term is significant and must remain in the model. An examination of main effects is not valid after a significant interaction is established. The full ANOVA model was therefore 
accepted as explaining significant variation in plankton density $(\mathrm{p}<0.001, \mathrm{~F}=12.05$, $\left.\mathrm{R}^{2}=0.832, \mathrm{n}=97\right)$.

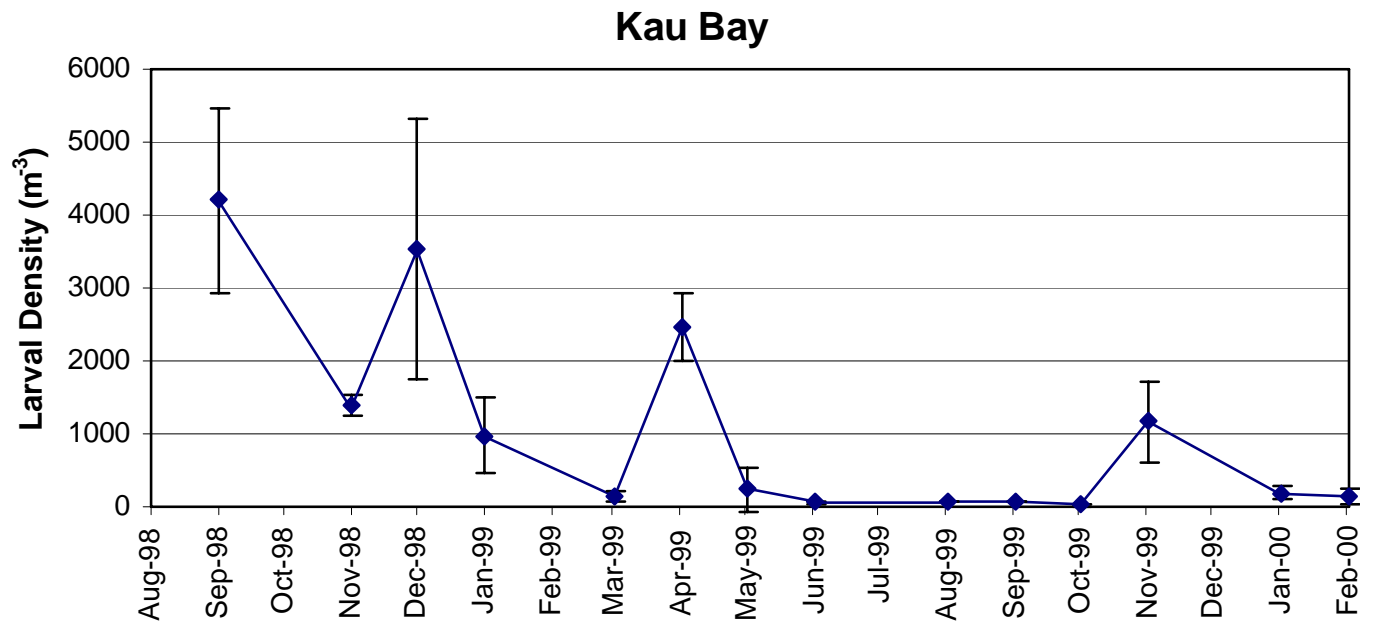

Island Bay

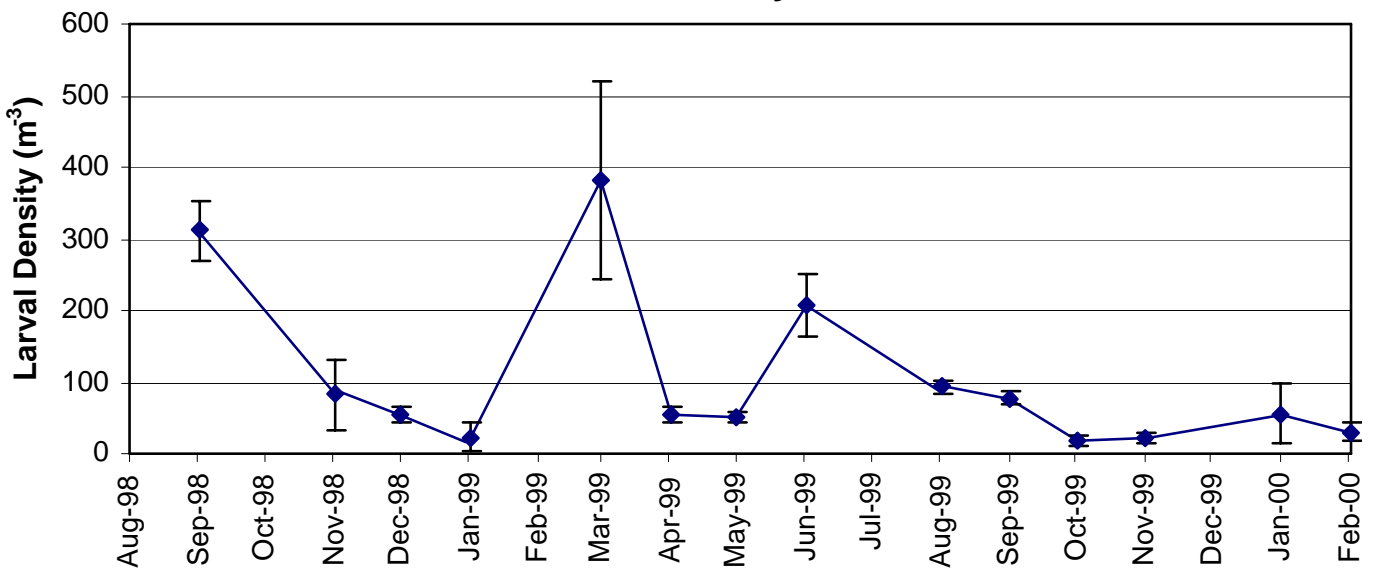

Oteranga Bay

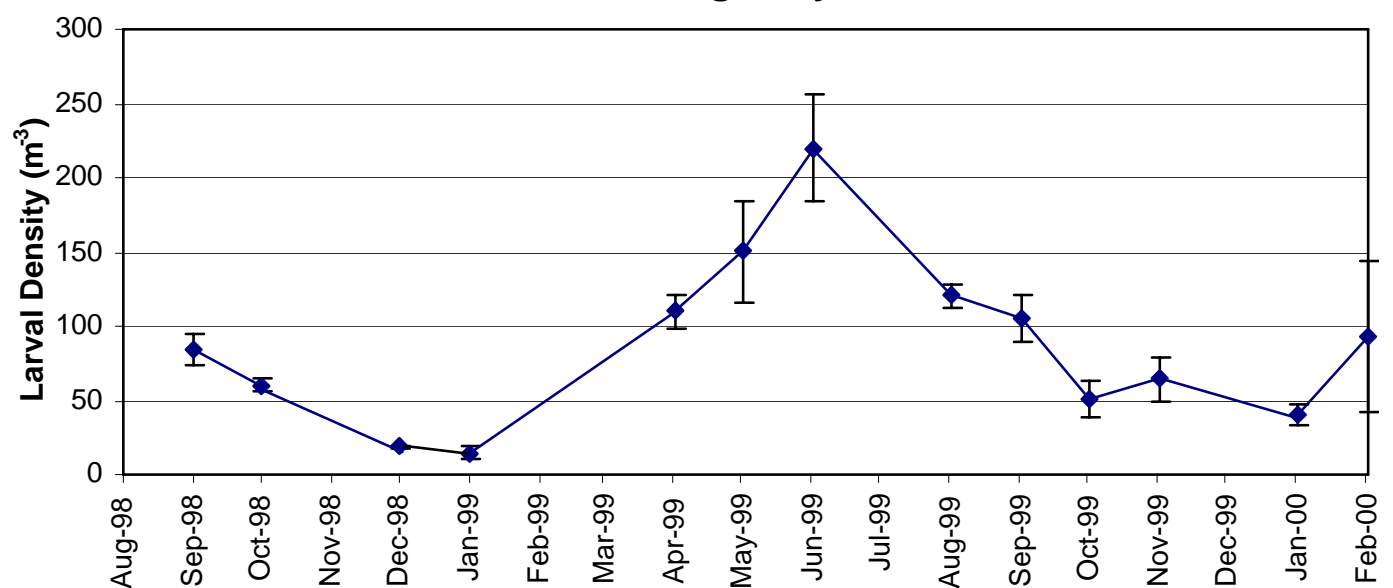

Figure 3.3. Mussel larval density at the three study sites, points are the mean of three samples, error bars show one standard deviation. Note difference in vertical scales. 
Table 3.3. Results of ANOVA of density of mussel larvae including temperature and salinity.

\begin{tabular}{l|cc}
\hline \multicolumn{1}{c|}{ Effect } & F-value & p-value \\
\hline Month & 15.052 & $<0.001$ \\
Site & 1.092 & 0.341 \\
Temperature & 24.675 & $<0.001$ \\
Salinity & 92.505 & $<0.001$ \\
Month * Site Interaction & 9.411 & $<0.001$ \\
\hline
\end{tabular}
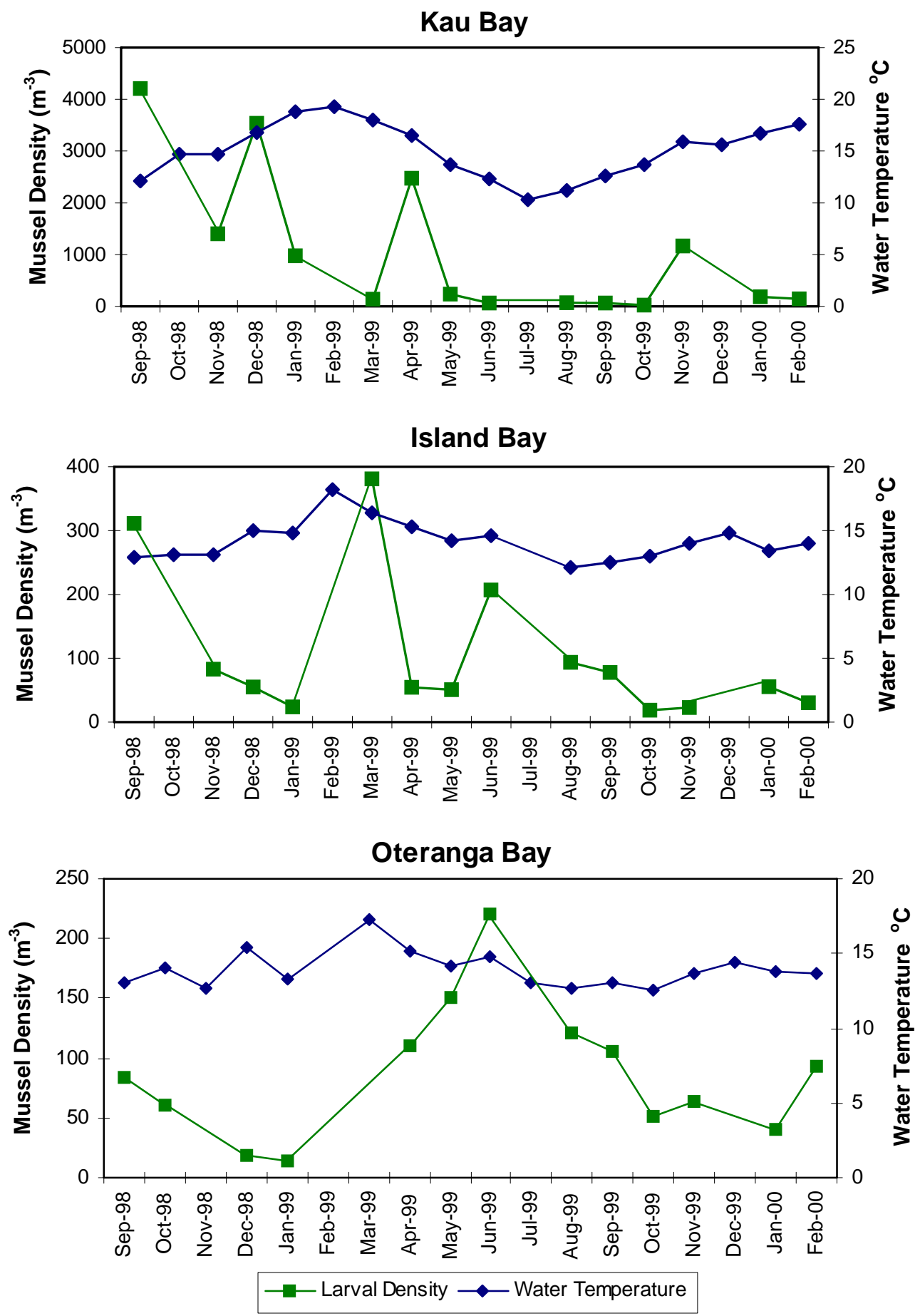

Figure 3.4. Relationship between mussel larval plankton density and temperature at all sites. 

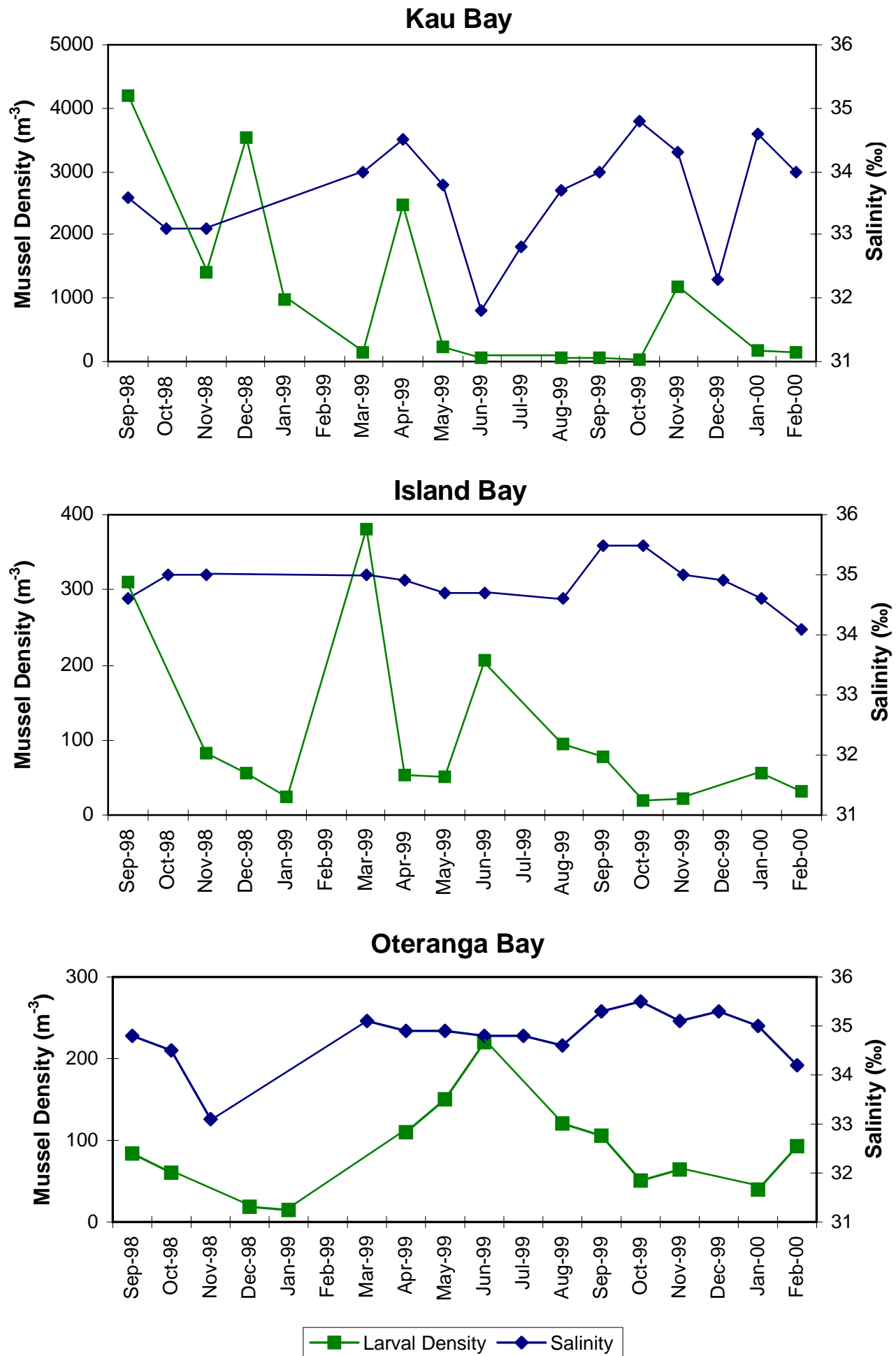

Figure 3.5. Relationship between mussel larval plankton density and salinity at all sites.

Differences also existed among months: much of this variation is associated with temperature and salinity at each site. Much of the spawning activity tends to be concentrated around the warmer summer months (Fig. 3.4). While the greatest fluctuation in water temperature occurred at the Harbour site, Kau Bay, the coastal 
sites also experience seasonal temperature changes, but not on the same scale as the Harbour. The same pattern exists for salinity because the Harbour has a much higher freshwater input compared to the Coast and as such, fluctuation in salinity is greater (Fig. 3.5).

A second analysis was conducted after the combination of the Coastal sites, Island Bay and Oteranga Bay. These data showed a similar result to the first analysis, with the full model being accepted ( $\mathrm{p}<0.001, \mathrm{~F}=11.987, \mathrm{R}^{2}=0.747, \mathrm{n}=97$ ) (Table3.4). As with the test among all sites, it appears that site is no longer significant. However, the significant month * site interaction means site is significant and must remain in the model. As with the previous test, it is not justified to examine main effects after a significant interaction has been demonstrated.

Table 3.4. Results of ANOVA of density of mussel larvae including temperature and salinity with Coastal sites combined.

\begin{tabular}{l|cc}
\hline \multicolumn{1}{c|}{ Effect } & F-value & p-value \\
\hline Month & 13.116 & $<0.001$ \\
Site & 1.589 & 0.211 \\
Temperature & 10.381 & $<0.001$ \\
Salinity & 61.224 & $<0.001$ \\
Month * Site Interaction & 11.234 & $<0.001$ \\
\hline
\end{tabular}

A pairwise analysis was conducted to detect differences between months within each site at Kau Bay (Table 3.5). The months in late spring/early summer through to late summer/early autumn were those with the highest larval densities and these months were significantly different from the remaining months. The matrix below shows the relationships between each month sampled, $\left({ }^{*}=\mathrm{p}<0.05,{ }^{*}=\mathrm{p}<0.001, \mathrm{NS}=\right.$ not significant, ND = no (or insufficient) data).

Table 3.5. Pairwise comparisons of larval density among months at Kau Bay.

\begin{tabular}{l|cccccccccccc}
\hline & Jan & Feb & Mar & Apr & May & Jun & Jul & Aug & Sep & Oct & Nov & Dec \\
\hline Jan & $\cdot$ & & & & & & & & & & & \\
Feb & NS &. & & & & & & & & & & \\
Mar & ND & ND &. & & & & & & & & & \\
Apr & NS & NS & ND &. & & & & & & & & \\
May & $* *$ & $* *$ & ND & $* *$ &. & & & & & & & \\
Jun & $* *$ & $* *$ & ND & $* *$ & $* *$ &. & & & & & & \\
Jul & ND & ND & ND & ND & ND & ND &. & & & & & \\
Aug & $* *$ & $* *$ & ND & $* *$ & $* *$ & $* *$ & ND &. & & & & \\
Sep & $* *$ & $* *$ & ND & $* *$ & NS & $* *$ & ND & $* *$ & & & & \\
Oct & $* *$ & $* *$ & ND & $* *$ & NS & $* *$ & ND & $* *$ & $*$ & & & \\
Nov & NS & NS & ND & $* *$ & $* *$ & $* *$ & ND & $* *$ & $* *$ & $* *$ & & \\
Dec & ND & ND & ND & ND & ND & ND & ND & ND & ND & ND & ND & . \\
\hline
\end{tabular}


As with the data for Kau Bay, the larval density at Island Bay (Table 3.6) is significantly different between months in late spring/early summer when compared to the winter months. This is in contrast to the data for Oteranga Bay (Table 3.7) where fewer significant differences occur. This indicates a lesser influence of season on larval density at Oteranga Bay, probably associated with the direction and swift nature of the currents and relative isolation from larval supply (Table 3.8). The number of overall differences between months is higher at Kau Bay where 29 of the 36 comparisons were significantly different compared to 17 of 36 at Island Bay and Oteranga Bay (Table 3.8).

Table 3.6. Pairwise comparisons of larval density among months at Island Bay.

\begin{tabular}{c|cccccccccccc}
\hline & Jan & Feb & Mar & Apr & May & Jun & Jul & Aug & Sep & Oct & Nov & Dec \\
\hline Jan & $\cdot$ & & & & & & & & & & & \\
Feb & NS &. & & & & & & & & & & \\
Mar & ND & ND &. & & & & & & & & & \\
Apr & $* *$ & $* *$ & ND &. & & & & & & & & \\
May & $* *$ & $* *$ & ND & $* *$ &. & & & & & & & \\
Jun & $* *$ & $* *$ & ND & NS & $* *$ &. & & & & & & \\
Jul & ND & ND & ND & ND & ND & ND &. & & & & & \\
Aug & NS & NS & ND & $* *$ & $* *$ & $* *$ & ND &. & & & & \\
Sep & NS & NS & ND & $* *$ & NS & $*$ & ND & $* *$ & & & & \\
Oct & NS & $*$ & ND & $* *$ & NS & $* *$ & ND & $* *$ & NS & $\cdot$ & & \\
Nov & NS & $* *$ & ND & $* *$ & NS & $* *$ & ND & $*$ & NS & NS & $\cdot$ & \\
Dec & ND & ND & ND & ND & ND & ND & ND & ND & ND & ND & ND &. \\
\hline
\end{tabular}

Table 3.7. Pairwise comparisons of larval density among months at Oteranga Bay.

\begin{tabular}{l|cccccccccccc}
\hline & Jan & Feb & Mar & Apr & May & Jun & Jul & Aug & Sep & Oct & Nov & Dec \\
\hline Jan & $\cdot$ & & & & & & & & & & & \\
Feb & NS &. & & & & & & & & & & \\
Mar & ND & ND &. & & & & & & & & & \\
Apr & $* *$ & $* *$ & ND &. & & & & & & & & \\
May & NS & $* *$ & ND & NS &. & & & & & & & \\
Jun & $* *$ & $* *$ & ND & NS & NS &. & & & & & & \\
Jul & ND & ND & ND & ND & ND & ND &. & & & & & \\
Aug & NS & NS & ND & $* *$ & $* *$ & $* *$ & ND &. & & & & \\
Sep & NS & $* *$ & ND & $* *$ & NS & $* *$ & ND & $* *$ & & & & \\
Oct & NS & NS & ND & $* *$ & $* *$ & $* *$ & ND & NS & NS &. & & \\
Nov & NS & $* *$ & ND & $* *$ & NS & $* *$ & ND & $* *$ & NS & NS & . & \\
Dec & ND & ND & ND & ND & ND & ND & ND & ND & ND & ND & ND & . \\
\hline
\end{tabular}

Table 3.8. Summary table of results from pairwise comparisons.

\begin{tabular}{r|ccc}
\hline & Kau Bay & Island Bay & Oteranga Bay \\
\hline$* *$ & 28 & 19 & 19 \\
$*$ & 1 & 3 & 0 \\
NS & 7 & 14 & 17 \\
\hline
\end{tabular}




\subsubsection{Settlement}

Settlement densities at the two Coastal sites were far less than those within the Harbour. The highest mussel density was recorded at Matiu-Somes Island in June 2000 with a mean of 16,914 mussels per pad. The second highest number of mussels was 4,680 in September 2000, also at Matiu-Somes Island. The Front Lead also recorded high mussel settlement with a maximum of 2,654 in April (Table 3.9). Moa Point and IBML recorded maxima of 144 and 297 respectively, in December (MP) and February (IBML) (Table 3.9). There appears to evidence of a gradient in the density of mussel settlement; Matiu-Somes > Front Lead > Coastal sites.

Table 3.9. Mean number of mussels per pad, standardised to a 30 day month.

\begin{tabular}{r|cccccccc}
\hline & \multicolumn{2}{|c}{ Matiu-Somes Island } & \multicolumn{2}{c}{ Front Lead } & \multicolumn{2}{c}{ Moa Pt } & \multicolumn{2}{c}{ Island Bay } \\
\hline & Mean & SD & Mean & SD & Mean & SD & Mean & SD \\
\hline Mar 00 & 156.88 & 63.63 & 188.13 & 25.72 & 125.85 & 56.71 & 129.51 & 4.24 \\
Apr 00 & 2172.00 & 705.98 & 2653.70 & 759.29 & 111.60 & 78.63 & 57.20 & 58.27 \\
May 00 & 4603.50 & 269.83 & 1021.70 & 454.67 & 32.57 & 6.22 & 74.31 & 67.46 \\
Jun 00 & 572.37 & 14.00 & 483.00 & 57.84 & 37.05 & 11.43 & 22.84 & 5.56 \\
Jul 00 & 16914.43 & 9095.91 & & & 42.71 & 46.54 & 64.36 & 32.16 \\
Aug 00 & 665.21 & 258.41 & 291.37 & 308.71 & 10.65 & 0.28 & 18.80 & 18.45 \\
Sept 00 & 4680.45 & 4840.25 & 839.65 & 238.48 & 41.53 & 12.80 & 55.24 & 30.47 \\
Nov 00 & 2597.50 & 896.52 & 409.65 & 12.70 & 37.42 & 20.33 & 76.26 & 40.49 \\
Dec 00 & 2061.89 & 728.17 & 873.05 & 84.39 & 144.32 & 108.62 & 162.72 & 104.29 \\
Jan 01 & 1182.90 & 468.60 & 754.14 & 376.40 & 40.37 & 26.51 & 122.28 & 88.80 \\
Feb 01 & 177.50 & 57.79 & 157.14 & 50.65 & 98.21 & 20.46 & 296.57 & 198.26 \\
\hline
\end{tabular}

Settlement numbers at Matiu-Somes Island showed small peaks in May and September, with a very large peak in July. Data from the Front Lead were more consistent over the year with a small peak in April (Fig. 3.6). The two Coastal sites show a very close relationship to each other, both had peaks in March, December and February (Figs. 3.7).

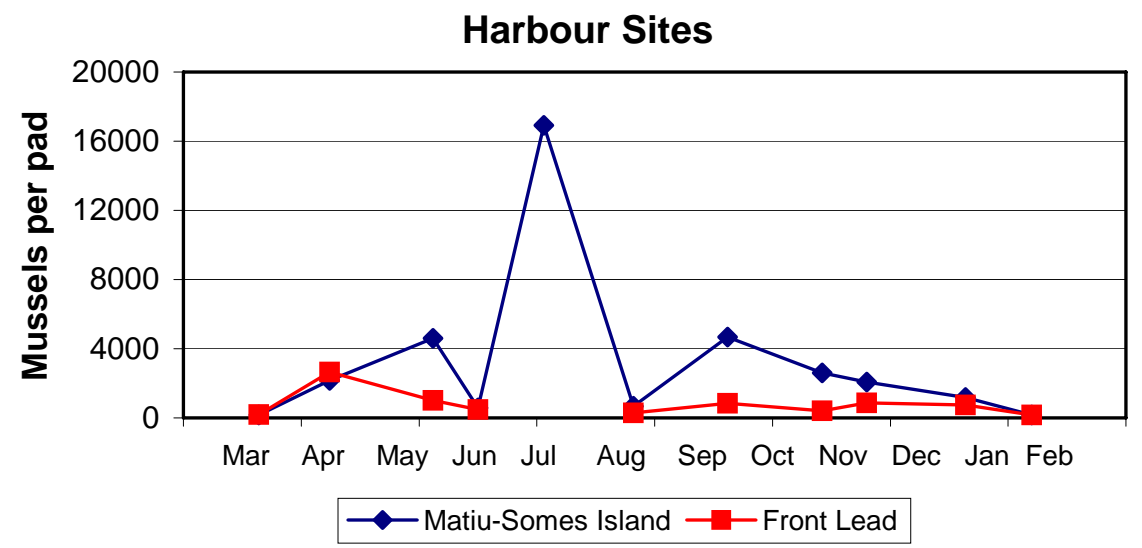

Figure 3.6. Mean number of mussels per pad at Harbour sites, standardised to a 30 day month. 


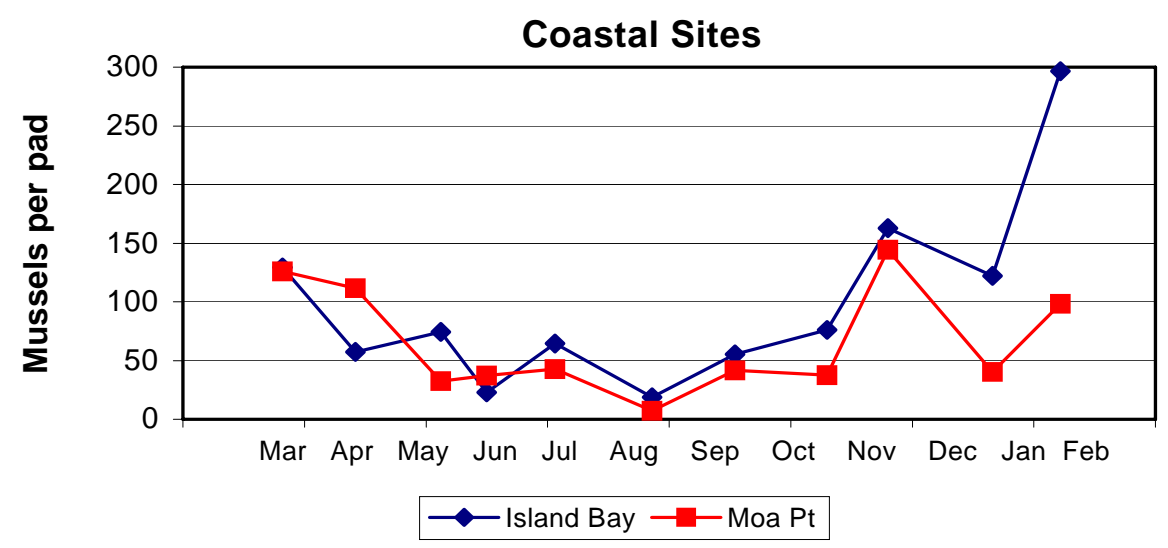

Figure 3.7. Mean number of mussels per pad at Coastal sites, standardised to a 30 day month.

An ANOVA was conducted to test the effects of site, month and the interaction upon settlement numbers. The model was accepted, and it is clear that differences do exist in settlement numbers among sites and times of the year $(\mathrm{p}<0.001, \mathrm{~F}=41.311$, $\left.\mathrm{R}^{2}=0.959, \mathrm{n}=117\right)$.

Table 3.10. Results of ANOVA of settlement data with separate sites.

\begin{tabular}{l|ccc}
\hline \multicolumn{1}{c|}{ Effects } & df & F-value & p-value \\
\hline Site & 3 & 188.128 & $<0.001$ \\
Month & 9 & 91.432 & $<0.001$ \\
Month * Site & 30 & 11.034 & $<0.001$ \\
\hline
\end{tabular}

A second test was conducted in which site data were combined into Harbour and Coastal sites. This test also showed significant differences between sites, months and the site * month interaction $\left(\mathrm{R}^{2}=0.923\right)$ (Table 3.11).

Table 3.11. Results of ANOVA of settlement data with sites combined.

\begin{tabular}{l|cccc}
\hline \multicolumn{1}{c|}{ Effect } & Sum of Squares & Mean Square & F-value & p-value \\
\hline Month & 97.753 & 9.775 & 21.803 & $<0.001$ \\
Site & 187.510 & 184.510 & 418.219 & $<0.001$ \\
Month * Site & 88.505 & 8.851 & 19.740 & $<0.001$ \\
Error & 42.594 & 0.448 & & \\
\hline
\end{tabular}

\subsection{Discussion}

As was seen in Kau Bay and Island Bay, the occurrence of major peaks in larval abundance from spring to late summer is a trend that is fairly common in mussel populations. Observations of $M$. galloprovincialis in NW Spain indicated a major 
spawning event in the spring (Cáceres-Martínez et al., 1993). Dare (1976) reported that plantigrades of Mytilus edulis were most abundant in Morecambe Bay, England in the plankton from April-July, with a peak in May-June. Similarly, Chipperfield (1953) reported spawning of Mytilus edulis in April-May (N. Hem.) and subsequent planktonic dispersal. Given the proximity of Island Bay to the large Harbour populations of mussels, it might be expected that Island Bay would show a similar temporal larval abundance pattern to the Harbour. However, peak larval abundance at Oteranga Bay was observed in the winter. Given that Oteranga Bay is $\approx 18 \mathrm{~km}$ further west than Island Bay, the nature of Cook Strait hydrology as discussed in Chapter One, and the strong currents and rips between the two sites, Oteranga Bay is unlikely to be as strongly influenced by larvae from the Harbour. It may be that Oteranga Bay receives larvae from a number of different locations because of the influence of many different water masses in the immediate vicinity (Chapter One). The influence on Coastal sites of larvae derived from the Harbour is difficult to ascertain. Given the long larval life of mussel larvae and the close proximity of the two sites, it may be that mussel larvae from the Harbour dissipate long before they are biologically fit for settlement at Coastal sites. It is likely that mussel populations in Wellington Harbour are not self-seeding. Wellington Harbour has a total flushing time of approximately 10 d (Heath, 1971) and therefore large numbers of larvae are likely to be transported out of the Harbour before they are able to settle. Tracey et al. (1975, p. 309) state that 'The probability that organisms with lengthy pelagic larvae settle in the population from which they were spawned is small, probably very close to zero. So almost all settling mussels are immigrants'. If this is the case, this does not exclude settlement of mussels on the Coast from the same source as those seeding the Harbour populations. The source of such seeding mussels is unknown, given conservative estimates of a two-week larval phase and a current of one knot; larvae could potentially travel in excess of $600 \mathrm{~km}$. An additional complication is that Cook Strait is supplied from three different directions by three major currents that originate from Subtropical and Subantarctic waters (Chapter One).

Temperature has long been regarded as a principal factor in determining the reproductive cycle in mussels (Wilson \& Hodgkin, 1967; Seed and Suchanek, 1992). Wilson and Hodgkin (1967) postulated that temperatures in Western Australia might rise above the range $\left(>25^{\circ} \mathrm{C}\right)$ at which $M$. edulis planulatus ( $=$ M. galloprovincialis) 
can breed, and that winter temperatures in Great Britain (various sites, see Chipperfield, 1953) are below the breeding range. It may be that water temperatures in Wellington Harbour $\left(10-20^{\circ} \mathrm{C}\right)$ are never too extreme to limit gonad development, hence larvae were observed in the water column and on settlement substrates all year round. However, Thompson (1984) has noted gamete formation in Mytilus edulis at water temperatures close to freezing, and gamete maturation has also been noted at temperatures higher than those cited as being possibly limiting by Wilson and Hodgkin (1967) (e.g. M. galloprovincialis spawning in Pearl Harbour, Oahu, Hawai'i at $26^{\circ} \mathrm{C}$, Apte et al., (2000)). Kennedy (1977) cites observations of gamete maturation in Mytilus edulis aoteanus at temperatures ranging from $24-28.5^{\circ} \mathrm{C}$. He also notes however, that examples exist where Mytilus edulis aoteanus was not exhibiting gametogenic activity in areas where water temperature did not exceed $19.5^{\circ} \mathrm{C}$.

Larval abundance has been closely linked to water temperature rise in the springsummer period (Cáceres-Martínez \& Figueras, 1998). An abundance of Mytilus edulis in the plankton was observed to peak 2-4 wk after spawning maxima in adult populations in the Schleswig-Holstein, Wadden Sea (Pulfrich, 1997). Kennedy (1977) studied histological sections of $M$. edulis aoteanus (=M. galloprovincialis) and A. maoriana from Taylors Mistake (South Is., New Zealand). He observed that spawning of M. edulis aoteanus began in late August and continued to a peak in late December. He also noted that spawning might have continued in some individuals until as late as March. Similar timing was noted in A. maoriana where spawning began by late August and continued into September, but this activity did not continue to the extent observed in M. edulis aoteanus (Kennedy, 1977). Whilst collecting A. maoriana and M. edulis aoteanus (=M. galloprovincialis) for histological sections, Kennedy (1977) also observed gonads of $P$. canaliculus and concluded that spawning occurred from late August to early February.

While temperature undoubtedly plays an important role in gonad maturation and subsequent spawning, there are other exogenous (e.g. salinity, food availability, rough weather) and endogenous (e.g. nutrient reserves, hormonal cycles, genotype) factors that must be taken into account (Seed \& Suchanek, 1992). Newell et al. (1982) and Bayne and Worrall (1980) found that food quality and availability, which themselves are related to water temperature, were instrumental in triggering spawning of Mytilus 
edulis. Studies of numerous urchin and chiton species by Himmelman (1981) concluded that spawning in the field usually, but not always, occurred at the same temperature. He notes however (p. 9), "It is difficult to imagine how a temperature threshold mechanism would be a reliable means of coordinating gamete release in intertidal populations”. Further experiments by Himmelman (1981) suggested that temperature and light were not external spawning cues. However, Himmelman (1981) noted a positive relationship between diatom bloom and spawning and suggested phytoplankton increase to be the signal for gamete release. Smith and Strehlow (1983) found that the unicellular alga, Pseudoisochrysis paradoxa caused copious and synchronous gamete release in Mytilus californianus. The cell-free fraction of the algal suspension also stimulated spawning, suggesting the active component is secreted into the culture by the algae. Algal suspensions with high $\mathrm{pH}$ values (8.6-9.4) induced significantly greater numbers of mussels to spawn than suspensions with low $\mathrm{pH}$ values (7.5-7.9) or seawater with high $\mathrm{pH}$ values (8.0-9.0). Smith and Strehlow (1983) suggested that algal-induced spawning is therefore dependent on alkaline conditions that act on mussels rather than on the algal by-products. Algal concentrations in their lab-based study were too high (2.5-7.0 million cells $\mathrm{ml}^{-1}$ ) to be realised under natural conditions, but suggest that adequate food supply may induce spawning in those animals physiologically predisposed to do so. Further evidence that phytoplankton acts as a spawning cue was presented for Mytilus edulis by Starr et al. (1990).

It is clear from the literature that a number of factors can be correlated with gonad development and subsequent spawning. However, the extent to which each of these factors contributes is not clear and these may vary in their influence from place to place. Latitude has also been implicated as a contributing factor in the timing and duration of mussel spawning events (Dorgelo \& Kraak, 1993). Hadfield and Anderson (1988) concluded that spawning was more likely to be linked to environmental cues such as temperature and food availability in temperate bivalve species. In contrast tropical species were more likely to have a prolonged spawning period under endogenous control. In this study, temperature and salinity were correlated with larval density. In temperate waters, temperature is certainly related to an increase in phytoplankton associated with the onset of spring. In species with planktotrophic larvae it is necessary to produce larvae when adequate food is available. In the case of 
salinity however, it is more difficult to hypothesise about a causal relationship between salinity and larval abundance, particularly in a species that is well known for its wide salinity tolerance (Kautsky 1982a, Seed \& Suchanek, 1992). It must also be noted that larvae are often more sensitive to salinity variation than adults and as such this reduced larval tolerance may limit the distribution of mussels species (Lutz \& Kennish, 1992). It is possible that salinity is a surrogate for some other unknown factor that is influential in mussel spawning in this population.

Observed densities of planktonic larvae at IBML and Oteranga Bay reached 381 and 220 larvae $\mathrm{m}^{-3}$ respectively. A search of settlement literature did not uncover any minimum larval density required to successfully colonise new substrate, however, there have been studies (Doyle, 1974) documenting settlement of individual larvae (Spirorbis borealis) and also the influence of existing mussels on the settlement behaviour of settling larvae (Meadows \& Campbell, 1972; Scheltema, 1974). One might reasonably expect that $\approx 380$ larvae $\mathrm{m}^{-3}$ would be sufficient to enable settlement of considerable numbers of larvae onto settlement substrates.

As expected, numbers of mussels settling onto artificial substrates within the Harbour were high. Settlement also occurred at both of the Coastal sites suggesting that larvae were competent and not prevented in some way from settling. There was some evidence of a gradient in mussels settlement density, namely Matiu-Somes > Front Lead > Coastal Sites. This may reflect the proximity to the source of larvae in addition to this, a small gyre are known to exist around Matiu-Somes Island which may result in larvae being retained close to the island for extended periods. In contrast, the Front Lead is located in the Harbour channel and is subject to fast current flows during tidal exchanges (pers. obs.). There is no difference in the underlying substratum among sites, settlement substrate at Harbour and Coastal sites consists primarily of the sedimentary rock, greywacke. Observations of populations of mussels within Wellington Harbour confirm that this underlying substrate is no impediment to mussel settlement when other biological and physical factors are suitable. Settlement at Harbour and Coastal sites occurred all year as has previously been observed for $M$. galloprovincialis (Ramirez \& Cáceres-Martínez, 1999). Ralph and Hurley (1952) also observed settlement of larval Mytilus edulis aoteanus (=M. galloprovincialis) all year round on wooden blocks in Wellington Harbour. Buchanan and Babcock (1997) 
observed settlement of $P$. canaliculus throughout the year, with a peak in the spring to summer. Similar findings were noted by Meredyth-Young and Jenkins (1978) in studies of $M$. edulis aoteanus (=M. galloprovincialis) and $P$. canaliculus in the Marlborough Sounds. They assumed that only primary settlement was being observed because the size of mussels settling on collectors was 250-300 $\mu \mathrm{m}$ for both species. Peak settlement occurred over a two month period from 20 October to 4 January in $M$. edulis aoteanus and between approximately 16 February and 12 April in $P$. canaliculus. In this study, settlement of larvae at all sites appeared to be primary in nature, with most animals in the size range of 250-500 $\mu \mathrm{m}$. It is well documented that larvae often attach initially to filamentous substrates away from adult populations (Petersen, 1984; King et al., 1990). Bayne (1964) demonstrated that larvae have the ability to detach from sites of primary settlement on filamentous substrates, and undergo a secondary pelagic phase prior to attachment to adult mussel beds. This drifting ability is retained in Mytilus edulis up to $2.5 \mathrm{~mm}$ in length (Seed \& Suchanek, 1992). Postlarvae require up to two months to reach this size, time enough to allow for significant distribution by ocean currents (Lutz \& Kennish, 1992). Buchanan and Babcock (1997) reported mucous drifting in P. canaliculus of up to $6 \mathrm{~mm}$ in length. However, they maintain that mussels only travel a few meters in such instances, usually to recruit to adult beds after primary settlement onto hydroids and filamentous algae when larvae are less than $500 \mu \mathrm{m}$ in length. This primary phase represents the main dispersal period of juvenile mussels and usually lasts between 4 to 6 weeks (Jeffs et al., 1999). Therefore, it is possible that animals were settling on the pads and subsequently detaching themselves before collection as very few animals over $1 \mathrm{~mm}$ were found at any site during the study period. However, doubt exists over the universal applicability of the primary-secondary settlement model as a number of studies have observed direct settlement onto adult beds (Petersen, 1984; McGrath et al., 1988) or failed to find any evidence of secondary dispersal phase (Kautsky, 1982b).

Hayden and Kendrick (1992) found a strong relationship between daily larval abundance and weekly settlement of $P$. canaliculus during February and March in the Marlborough Sounds. However, this relationship was highly variable, especially at fine spatial scales. Paine (1974) also observed a high degree of variation in larval settlement of $M$. califorianus. His observations over a ten year period showed that 
settlement was patchy, separated spatially and was not an annual event. As with spawning, successful settlement will be influenced by multiple factors, which will vary in their influence in different places. Studies to determine the degree to which various factors influence spawning and settlement are outside the scope of this study.

The aim of this study was to determine whether larval supply and settlement were significant factors in the absence of mussels from Wellington's South Coast. Mussels were found in the plankton at both Coastal sites all year round, however, larval densities at Coastal sites were approximately an order of magnitude lower than inside the Harbour. Maximum densities of 381 larvae $\mathrm{m}^{-3}$ at Island Bay should be sufficient to allow at least some mussels to colonise the South Coast, although no evidence exists to determine the minimum number of mussels required for colonisation. However, the fact that mussels did settle on substrates at Coastal suggests that this assertion is justified. A similar pattern was observed when investigating mussel settlement. Settlement occurred at both Harbour and Coastal sites all year round in densities of up to 297 mussels on a 200 x $200 \mathrm{~mm}$ pad at Island Bay. As with data from planktonic larval collection, settlement at Harbour sites was generally an order of magnitude, and in one instance, two orders greater than at Coastal sites. Given that the availability of larvae is an order of magnitude less at Coastal sites, lower settlement densities at Coastal sites are not unexpected. These experiments have shown that mussel larvae are present in the plankton and are settling at Coastal sites. Therefore, larval supply and subsequent settlement are only likely to be of limited importance in restricting mussel distributions in this area. 


\section{CHAPTER FOUR}

\section{Condition Indices and Gonad Mass}

\subsection{Introduction}

A relatively simple method of estimating mussel fitness is by way of a condition index. The shell weight of a mussel is relatively fixed compared to its flesh weight, however, the soft tissues of a mussel will reflect the conditions to which the mussel is subjected. Under stress the soft tissue will experience atrophy and show a lower ratio of tissue weight to shell weight (Bayne, 1973). A healthy adult animal will undergo somatic and reproductive growth, and hence have a higher ratio of flesh weight to shell weight. A number of different methods for determining condition have been used (Davenport \& Chen, 1987) but all are based on this fundamental principle. Many different factors are thought to influence the condition of mussels including, but not limited to, temperature, salinity, food supply (Hickman et al., 1991; Seed \& Suchanek, 1992), parasitism (Theisen, 1987), spawning fitness (Emmett et al., 1987) and tidal height (Marsden \& Weatherhead, 1999). Zandee et al. (1980) showed a dramatic decline in condition index during spawning of Mytilus edulis from the Wadden Sea. The authors demonstrated a decrease in mussel protein and glycogen over the period from November-April, and attributed these losses to food scarcity and the metabolic requirements of gametogenesis. Reusch and Williams (1999) found that the mussel Musculista senhousia showed a reduction in condition index when transplanted into eelgrass beds that reduced water flow and nutrient flux compared to those from the parent population where eelgrass was absent. Indices of body condition have also been used to study other bivalves. Rheault and Rice (1996) reported a negative linear correlation between condition index and consumed chlorophyll $a$ ration in the eastern oyster Crassostrea virginica and the bay scallop Argopecten irradians. They also noted that doubling the stocking density of $C$. virginica resulted in a $20 \%$ decrease in oyster condition index and growth rate as a consequence of food limitation. Condition index has also been shown to respond to increases in pollution. For example, Granby and Spliid (1995) reported a significant decrease in the condition of Mytilus edulis from Danish waters in the presence of high concentrations 
of polyaromatic hydrocarbons. The mass of gonad present in mussels is of interest, not only from an ecological perspective as an indication of spawning, but also when an animal is under stress these tissues may be resorbed and used to supplement an inadequate diet (Bayne \& Newell, 1983; Emmett et al., 1987).

Bayne (1973) outlined a number of responses of M. edulis to starvation, among which was the utilisation of body reserves. He reported that depletion of reserves (glycogen) from the digestive gland occurred rapidly after the onset of starvation, while prolonged starvation lead to depletion of reserves (protein) in the mantle and other tissues in order to maintain basal energy requirements.

As a more sensitive method of detecting condition loss in stressed animals, a biochemical method was employed. The concentration of DNA per nucleus is the same for all somatic cells within a given species (Kenchington, 1994), and therefore remains essentially constant with changing environmental conditions (Dortch et al., 1983; Clemmesen, 1988; Robinson \& Ware, 1988; Robbins et al., 1990 and Chícharo, 1998). RNA is necessary for cell division and therefore will increase as somatic and reproductive growth occurs (Wright \& Hetzel, 1985; Clemmesen, 1987; Clarke et al., 1989 and Chícharo, 1998). It is therefore assumed that individuals that are starved or experiencing some sort of stress will show a decreased RNA:DNA ratio as the rate of cell division reduces. A number of studies have used this technique to good effect in the study of larval fish (Raae et al., 1988; Robinson \& Ware, 1988; McGurk et al., 1992; Clemmesen, 1994; Grønkjær et al., 1997) and Japanese glass-eels Anguilla japonica (Kawakami et al. 1999), and with bivalves (Wright \& Hertzel, 1985; Robbins et al., 1990; Kenchington, 1994; Chícharo \& Chícharo, 1995; Lodeiros et al. 1996). Wright and Hetzel (1985) showed that the RNA:DNA ratio decreased significantly in the American oyster (Crassostrea virginica) when starved individuals were compared to those feeding normally. In a similar study of the clam Ruditapes decussatus, Chícharo and Chícharo (1995) showed that starved individuals had a lower RNA:DNA ratio than did those feeding normally. These findings were echoed in a study by Kenchington (1994) who concluded that RNA:DNA ratio might be of use in detecting nutritional stress in wild populations of the sea scallop Placopecten magellanicus. 
If animals were present in the plankton and were able to settle on Wellington's South Coast, their absence from Coastal substrates may be attributable to a lack of good quality nutrients in the water. If animals that were feeding on ambient Cook Strait seston were effectively starving to death because of poor water quality, this stress should be detectable through a decrease in condition of animals feeding on Coastal seston relative to those feeding in the Harbour. Similarly, any stress caused by suboptimal conditions may be detected as a decrease in gonad mass, as this tissue has been shown to be resorbed under conditions of nutritive stress. It is expected that the ratio of RNA to DNA will also decrease in mussels that are undergoing stress when compared to those from the natural population.

\subsection{Materials and Methods}

\section{First Condition Experiment}

Samples of approximately 300 adult mussels of each species (P. canaliculus, A. maoriana and M. galloprovincialis) were collected at the low tide mark from Seatoun in November 1998 (Fig. 4.1).

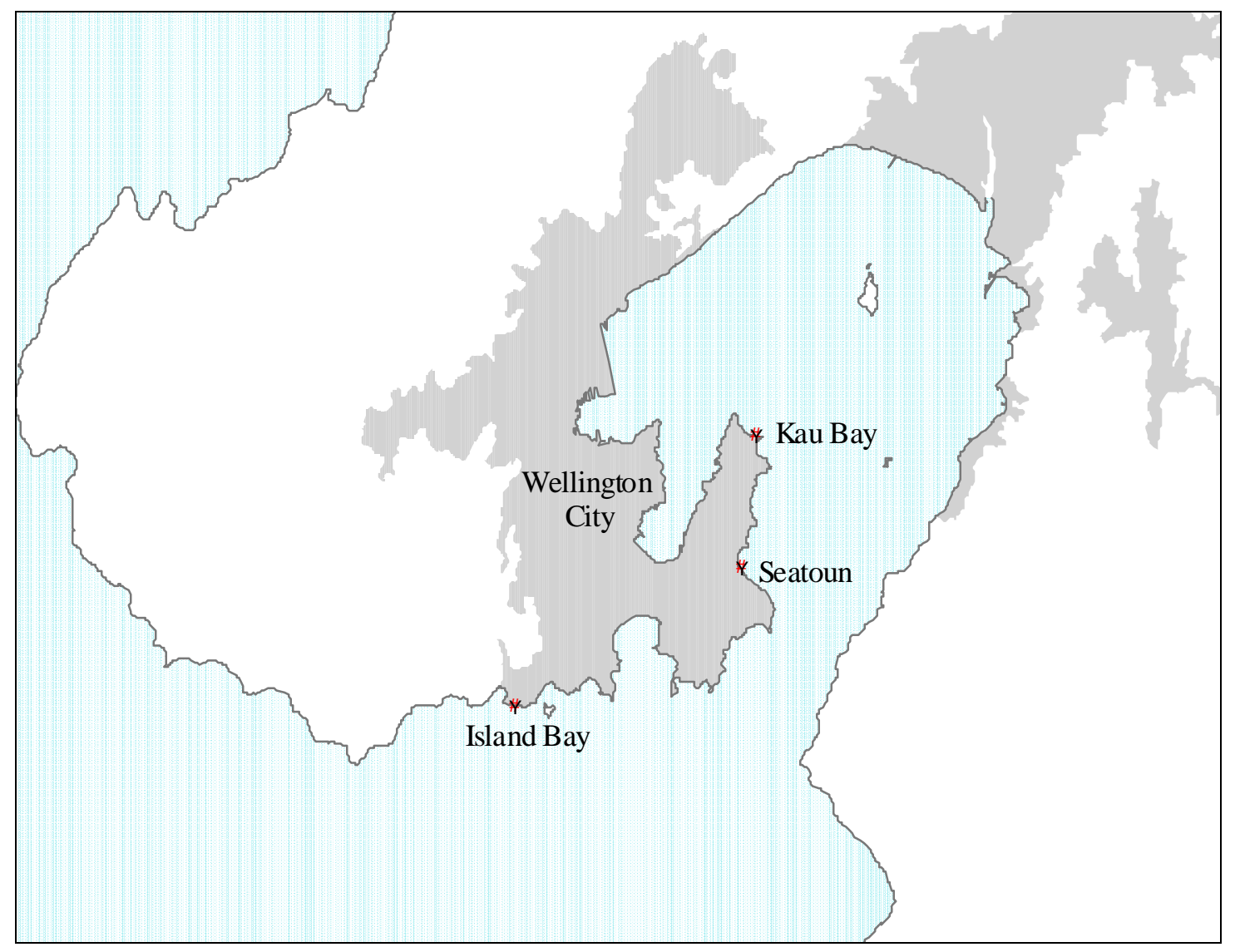

Figure 4.1. Locations of mussel collection sites (Seatoun and Kau Bay) and Island Bay. 
The mussels were taken back to the Island Bay Marine Laboratory (IBML) and held in $\approx 15$ aquaria $(l \times w \times d, 590 \times 300 \times 230 \mathrm{~mm})$ that were supplied with ambient Cook Strait water. Water entering aquaria at IBML is not significantly different from ambient Cook Strait water, with the exception of fewer larger particles $(60 \mu \mathrm{m})$ which are not a major food source of mussels (Gardner, 2000; Gardner \& Thompson, 2001). Care was taken to ensure the stocking density was approximately similar to natural densities and not so high as to limit access to food. Seston characteristics used in these experiments were taken from the analysis outlined in Chapter Two; water samples from Inner Dorset and Island Bay were used for the analyses.

An initial sample of 20 mussels of each species was taken and the condition of each mussel was calculated. Condition was measured using the following formula as recommended over six others by Hickman and Illingworth (1980):

$$
\text { Condition }=\text { Dry flesh weight } * 100 / \text { (whole wet weight }- \text { shell weight })
$$

The gonad of all animals was excised before the remainder of the tissue and dried separately to enable the comparison of gonad tissues, this gonad tissue was accounted for in the estimation of condition. All measurements were made using an Ainsworth ACA $100 \mathrm{KS}$ balance to an accuracy of $0.0001 \mathrm{~g}$ and tissues were dried at $60^{\circ} \mathrm{C}$ for 24-48 h depending on the size of the mussel. All gonad masses were standardised to the mean shell length of each species ( $P$. canaliculus, $75 \mathrm{~mm}$; A. maoriana, $50 \mathrm{~mm}$ and M. galloprovincialis, $55 \mathrm{~mm}$ ) to avoid problems associated with size related bias. All data were standardised using the following equation:

$$
\mathrm{Y}_{\mathrm{s}}=\left(\mathrm{W}_{\mathrm{s}} / \mathrm{W}_{\mathrm{e}}\right)^{\mathrm{b}} \mathrm{Y}_{\mathrm{e}}
$$

where $Y_{\mathrm{s}}$ is the gonad mass of the standard animal, $\mathrm{W}_{\mathrm{s}}$ is the standard length (75, 50 or $55 \mathrm{~mm}), \mathrm{W}_{\mathrm{e}}$ is the length of the experimental animal, $b$ is weight power for gonad mass and $\mathrm{Y}_{\mathrm{e}}$ is the uncorrected gonad mass. The regression equations from which the weight powers for gonad mass $b$ were derived, are as follows:

Harbour: $\quad P$. canaliculus, $\mathrm{Y}=0.20(\mathrm{x})-0.35, \mathrm{R}^{2}=0.338, \mathrm{n}=358$
A. maoriana, $\mathrm{Y}=0.39(\mathrm{x})-0.62, \mathrm{R}^{2}=0.250, \mathrm{n}=357$
M. galloprovincialis, $\mathrm{Y}=0.25(\mathrm{x})-0.40, \mathrm{R}^{2}=0.245$, $\mathrm{n}=360$ 
IBML: $\quad P$. canaliculus, $\mathrm{Y}=0.31(\mathrm{x})-0.57, \mathrm{R}^{2}=0.303, \mathrm{n}=97$
A. maoriana, $\mathrm{Y}=0.41(\mathrm{x})-0.64, \mathrm{R}^{2}=0.278, \mathrm{n}=208$
M. galloprovincialis, $\mathrm{Y}=0.18(\mathrm{x})-0.284, \mathrm{R}^{2}=0.282, \mathrm{n}=120$

Following the initial collection, 20 mussels of each species were collected each month at low tide from Seatoun and 20 mussels of each species were taken from the aquaria at IBML. Individual gonad mass and condition were calculated. Care was taken to avoid collecting mussels from different tidal heights as this has been shown to influence condition in P. canaliculus (Hickman \& Illingworth, 1980; Marsden \& Weatherhead, 1999). At approximately two-week intervals the aquaria at IBML were cleaned and any dead mussels were removed and counted. The experiment ran until the supply of mussels of each species from IBML was exhausted, this was 5 mo for $P$. canaliculus, 11 mo for A. maoriana and 6 mo for $M$. galloprovincialis. When dissecting mussels, any observations of the pea crab Pinnotheres novaezelandiae were noted. The carapace width was measured $( \pm 1 \mathrm{~mm})$ and the crab was dried at $60^{\circ} \mathrm{C}$ for $24 \mathrm{~h}$, and weighed to an accuracy of $0.0001 \mathrm{~g}$.

\section{Second condition experiment}

The condition experiment was repeated in 1999/2000 to validate the results of the initial experiment and to assess inter-annual variation between years (Hickman et al., 1991). At the original site, numbers of $P$. canaliculus and A. maoriana in the low intertidal were not sufficient to enable it to be used a second time. A new site was chosen to ensure enough mussels were available for monthly inter-tidal collection, the second site was relatively close, and not significantly different to the original site. Initial mussel samples were collected from Kau Bay in September 1999 (Fig. 4.1). In this experiment gonad mass was not measured; data were collected for mussel condition. It was felt after the first experiment that the results of the analyses of gonad mass data were ambiguous and not providing enough useful information to justify another experiment. As with the first experiment, all mortalities were counted, and all other protocols were the same as in the previous experiment. The experiment ran until the supply of mussels of each species from IBML was exhausted, this was 5 mo for $P$. canaliculus, 10 mo for A. maoriana and 7 mo for M. galloprovincialis. As in the first experiment, the presence of pea crabs was also noted. 


\section{RNA:DNA Index}

Approximately 50 mussels of each species (P. canaliculus, A. maoriana and $M$. galloprovincialis) were collected from Kau Bay on 30 September, 1999. These animals were taken to IBML and held in aquaria supplied with ambient Cook Strait water. At weekly intervals, five individuals of each species were removed from the aquaria and frozen at $-20^{\circ} \mathrm{C}$ for subsequent analysis. Five individuals of each species were also collected from Kau Bay on the same day and frozen at $-20^{\circ} \mathrm{C}$ for later analysis. Animals were sampled for a total of nine weeks between 30 September and 6 December 1999.

The nucleic acid extraction method used was based on that of Clemmesen (1988) and has subsequently been used with minor modifications by a number of workers (Chícharo \& Chícharo, 1995; Folkvord et al., 1996; Grønkjær et al., 1997; Chícharo, 1998; Kawakami et al., 1999; Esteves et al., 2000). This method involves the extraction of nucleic acids from tissues and subsequent fluorometric measurement after the addition of a fluorescent nucleic acid dye, ethidium bromide (EtBr) (Fig. 4.2). Mantle edge tissue is most commonly used in studies of bivalve RNA:DNA ratio (Wright \& Hetzel, 1985; Kenchington, 1994; Paon \& Kenchington, 1995). This tissue is chosen because of the likelihood of it reflecting growth through its rapid production of shell at the growing edge in bivalves (Wright \& Hetzel, 1985; Kenchington, 1994). After extraction the nucleic acid mixture was washed to remove impurities using a phenol : chloroform : isoamyl alcohol wash and then washed again in chloroform : isoamyl alcohol to remove any residual traces of phenol. The remaining supernatant was split into two samples; one was analysed fluorimetrically for total nucleic acid concentration (RNA \& DNA) after the addition of ethidium bromide. The other was treated with DNase-free RNase and incubated to remove all RNA, then analysed fluorimetrically after the addition of $\mathrm{EtBr}$ to give the DNA concentration. The difference between the two samples represents the RNA concentration. Calibrations were run using calf thymus DNA and yeast RNA prior to experimental readings. Ten calibration concentrations were used for RNA and DNA over a range from 0.005 to $2.5 \mathrm{mg} \mathrm{ml}^{-1}$ (DNA, $\mathrm{R}^{2}=0.9896$; RNA, $\left.\mathrm{R}^{2}=0.9924\right)$. Fluorescence was measured using a Perkin Elmer Luminescence Spectrometer LS 50 B, the analysis software used was Perkin Elmer FL Winlab 1997. 
Excise a small amount of mantle edge tissue and record blotted wet weight and shell length

Homogenise in $1 \mathrm{ml}$ of extraction buffer. $0.05 \mathrm{M}$ Tris, $0.1 \mathrm{M} \mathrm{NaCl}, 0.01 \mathrm{M}$ EDTA, $0.2 \mathrm{mg} \mathrm{ml}^{-1}$ proteinase $\mathrm{K}, 2 \%$ SDS, $\mathrm{pH} 8.0$

Mix for $15 \mathrm{~min}$

Centrifuge at $6000 \mathrm{rpm}$ for $15 \mathrm{~min}$

Pipette $800 \mu \mathrm{l}$ of supernatant into new eppendorf and add $300 \mu \mathrm{l}$ phenol and $300 \mu \mathrm{l}$ chloroform : isoamyl alcohol (24:1)

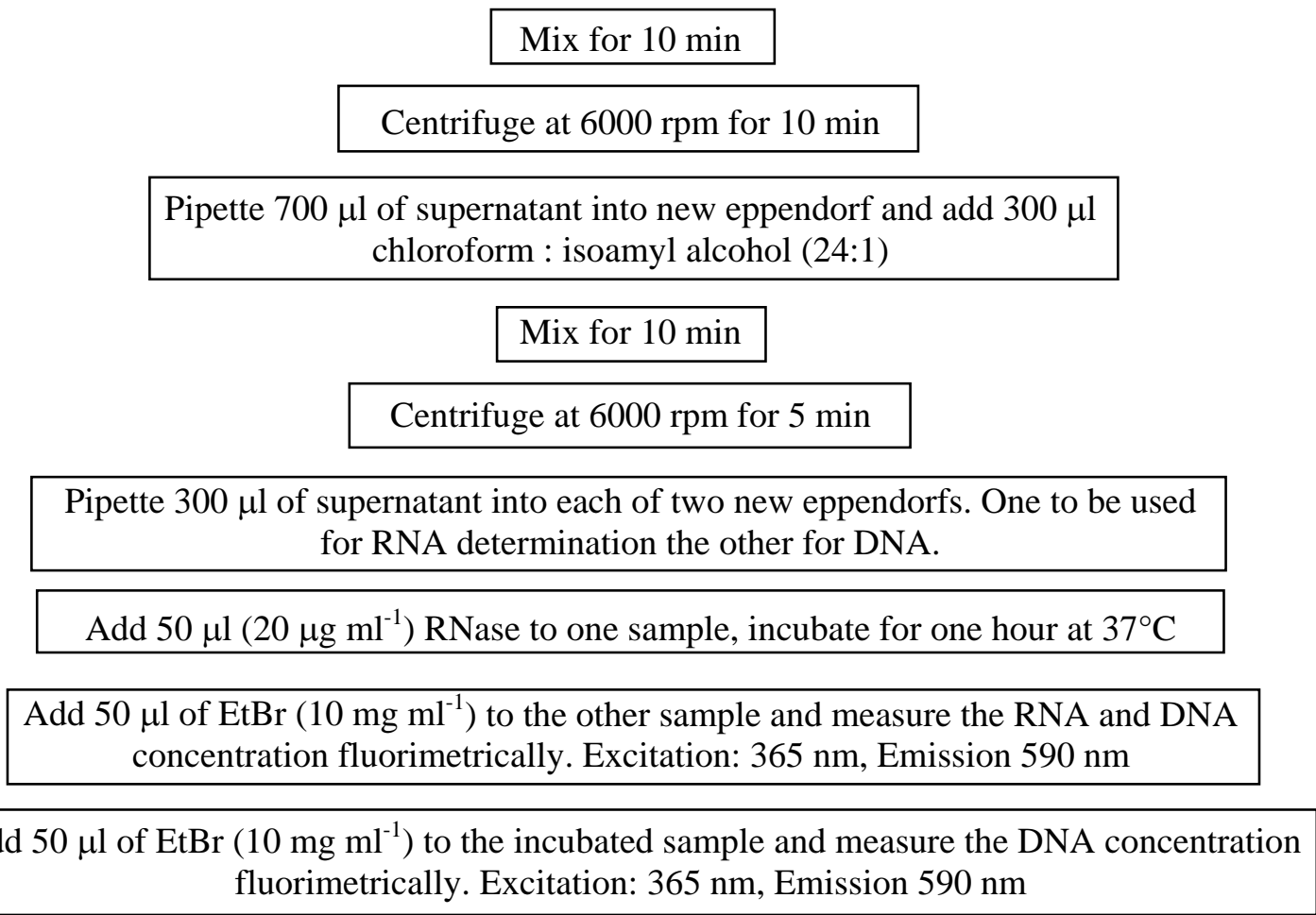

Figure 4.2. Flow chart showing procedure for the extraction of RNA and DNA from mussels.

\section{Data Analysis}

\section{Condition Index}

For both condition experiments, an ANOVA was conducted for each species to test for differences in condition index between Harbour mussels and those transferred to IBML. Differences between months and the interaction were also tested. Two outliers were identified, removed and the analysis repeated for $P$. canaliculus. Pearson correlation statistics were calculated between ten water sample variables and condition indices from the Harbour and IBML populations. An ANOVA was used to compare the condition of mussels with and without pea crab infestation for each 
species. Linear ANOVA was conducted as the data were not considered non-linear enough to justify a non-linear analysis.

\section{Gonad Mass}

Gonad mass in P. canaliculus was tested for differences between Harbour mussels and those transferred to IBML using a non-parametric Kruskal-Wallis test. An ANOVA was initially attempted but the data violated the assumptions despite numerous attempts at transformation (log, $\mathrm{x}^{2}, \sqrt{\mathrm{x}}, 1 / \mathrm{x}$, logit). For $A$. maoriana and $M$. galloprovincialis, step-wise ANOVA were used to test for differences in gonad mass between sites, months and the interaction term. Entry to and removal from the analysis was set at $\alpha=0.15$.

\section{RNA:DNA}

For all species a stepwise ANOVA was conducted to test for differences among sites, days, and the interaction for RNA, DNA and RNA:DNA. Entry to and removal from the analysis was set at $\alpha=0.15$. While the analysis of ratios often requires data to be transformed to meet the assumptions of ANOVA, in this case diagnostic tests showed the assumptions were not violated and transformation of the data was not required. Shell length was not included in the analysis as this was not deemed to vary to a biologically significant degree between sites (Table 4.22), although RNA:DNA has been shown vary according to shell length in some studies (see discussion). For each species ANOVA were also conducted to test for differences at each site in RNA, DNA and RNA:DNA over the period of the experiment. An ANOVA was also conducted to test for differences in shell length between sites for each species.

\subsection{Results}

\subsubsection{First Condition Experiment}

It quickly became evident that mussels held at IBML were losing condition when compared to those collected directly from the Harbour population. Condition in the Harbour populations fluctuated over the sampling period, while the IBML populations begin to decrease almost immediately (Fig. 4.3). All three species showed a gradual decrease in condition over the spring and summer months to a minimum in autumn and winter. Mean condition was lower in all species at IBML compared to Harbour mussels (Fig. 4.3). Condition was monitored in Harbour mussels for 18 months, but 
due to high mortality among IBML mussels, data were collected over a shorter period. As such, in Table 4.1, only Harbour data were used to compare with IBML if they had a corresponding observation at IBML.

Table 4.1. Comparison of mean condition index between Harbour and IBML. Only Harbour data were used when they had comparable data from IBML.

\begin{tabular}{l|c|cc}
\hline & $\begin{array}{c}\text { Period of } \\
\text { Comparison }\end{array}$ & $\begin{array}{c}\text { Harbour Condition } \\
( \pm \text { SD })\end{array}$ & $\begin{array}{c}\text { IBML Condition } \\
( \pm \text { SD })\end{array}$ \\
\hline P. canaliculus & Jan - May & $15.48( \pm 1.79)$ & $12.85( \pm 3.35)$ \\
A. maoriana & Jan - Nov & $18.50( \pm 1.94)$ & $14.47( \pm 4.33)$ \\
M. galloprovincialis & Jan - Jun & $15.63( \pm 0.82)$ & $13.33( \pm 2.47)$ \\
\hline
\end{tabular}

\section{Statistical analysis - P. canaliculus}

An ANOVA on logged data was conducted to test for differences in condition index among months, between sites and for the month * site interaction. Month and month * site were both highly significant ( $\mathrm{p}<0.001$, month $\mathrm{F}=23.33$, interaction $\mathrm{F}=12.23$ ), site was also significant ( $\mathrm{p}=0.019, \mathrm{~F}=5.59$ ). The overall model was therefore significant $\left(\mathrm{p}<0.001, \mathrm{~F}=36.3, \mathrm{R}^{2}=0.66, \mathrm{n}=237\right)$. The assumptions associated with this test were accepted, although two cases were highlighted as outliers. These were removed from the data set and the test was repeated. The second ANOVA showed month, site and the month * site interaction all to be highly significant $(\mathrm{p}<0.001$, month $\mathrm{F}=30.85$, site $\mathrm{F}=67.18$, interaction $\mathrm{F}=11.68$ ). The overall fit of the model was also improved $\left(\mathrm{p}<0.001, \mathrm{~F}=44.0, \mathrm{R}^{2}=0.704, \mathrm{n}=235\right)$.

\section{A. maoriana}

An ANOVA was conducted on the raw data to test for differences in condition index among months, between sites and for the month * site interaction, all of which were significant $(\mathrm{p}<0.001$, month $\mathrm{F}=19.76$, site $\mathrm{F}=21.06$, interaction $\mathrm{F}=6.00)$. The overall model was therefore accepted $\left(\mathrm{p}<0.001, \mathrm{~F}=22.6, \mathrm{R}^{2}=0.539, \mathrm{n}=448\right.$

\section{M. galloprovincialis}

As with the other two species, an ANOVA was conducted on the raw data to test for differences in condition index among months, between sites and for the month * site interaction, all were highly significant $(\mathrm{p}<0.001$, month $\mathrm{F}=17.12$, site $\mathrm{F}=64.23$, 
interaction $F=10.56)$. The overall model was accepted $\left(\mathrm{p}<0.001, \mathrm{~F}=27.1, \mathrm{R}^{2}=0.568\right.$, $n=260)$.

First Experiment Perna canaliculus

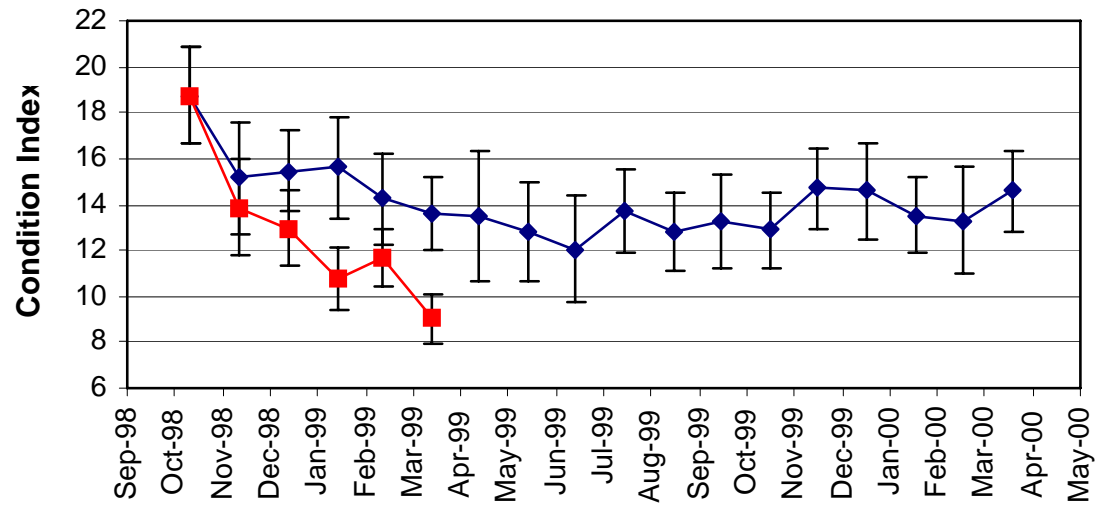

First Experiment Aulacomya maoriana

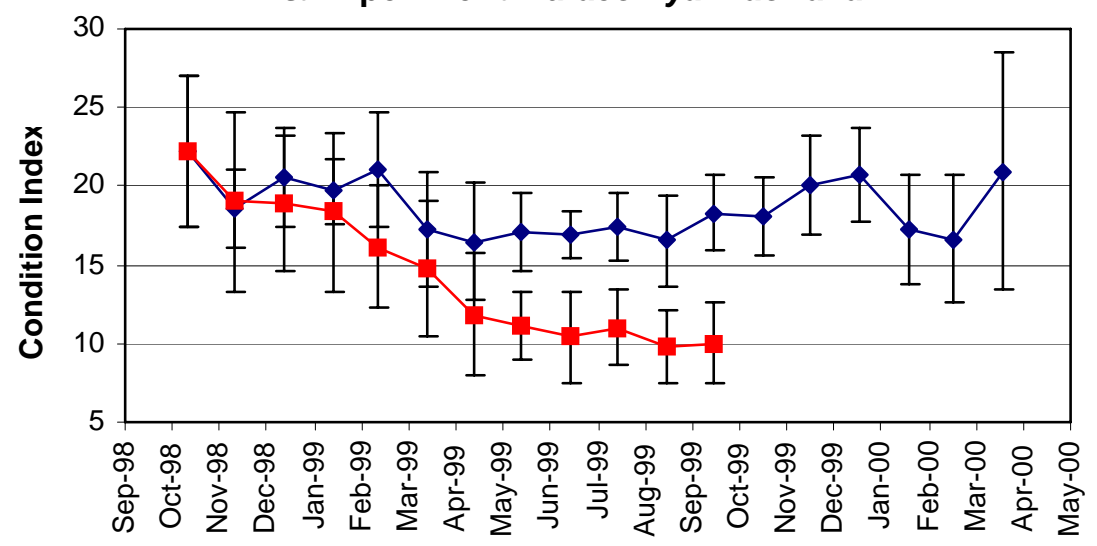

First Experiment $M$. galloprovincialis

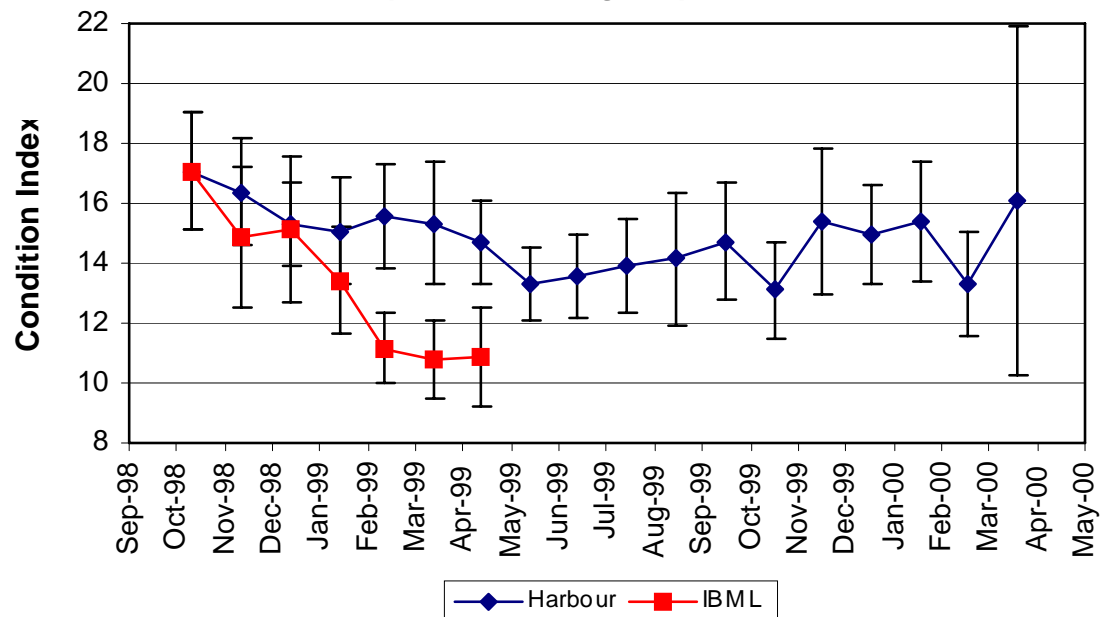

Figure 4.3. Comparison of condition indices for all three species between a Harbour population and individuals from the same population transferred to IBML (mean $\pm S D, n=20$ ). 
As described in Chapter Two, water samples at Coastal sites were generally of lower nutrient quality compared to those from Harbour sites. The data from water samples given in Tables 4.2 \& 4.3 are from Island Bay and Inner Dorset and represent the closet water sampling site to each of the sites where mussel condition was assessed. These tables show that water quality was greater at Inner Dorset during the condition experiments at conducted at IBML.

Table 4.2. Water characteristics from Island Bay during the time mussels were held at IBML for condition index experiments.

\begin{tabular}{|c|c|c|c|c|c|c|c|c|c|c|c|}
\hline & 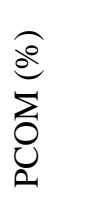 & 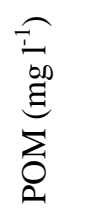 & 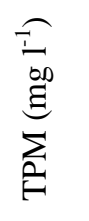 & 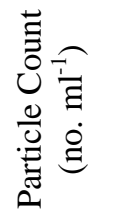 & 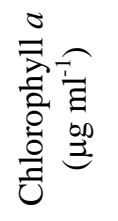 & 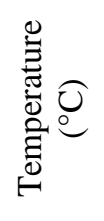 & 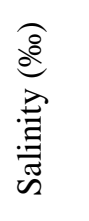 & 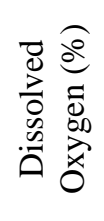 & $\begin{array}{l}z_{\dot{u}} \\
\end{array}$ & 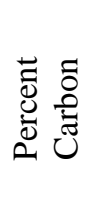 & 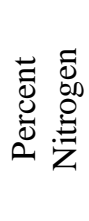 \\
\hline Nov-98 & 24.2 & 3.5 & 14.4 & 12854 & 0.06 & 13.4 & 35 & & 5.2 & 21.3 & 3.1 \\
\hline Dec-98 & 23.8 & 2.9 & 12.4 & 9268 & 0.07 & 15.0 & & & & & \\
\hline Jan-99 & 16.3 & 1.8 & 10.8 & 11081 & 0.05 & 14.8 & & & 9.0 & 11.3 & 1.3 \\
\hline Feb-99 & 19.2 & 3.7 & 19.3 & 37938 & 0.13 & 18.2 & & & 7.2 & 13.5 & 1.9 \\
\hline Mar-99 & 28.8 & 3.5 & 12.0 & 4422 & 0.35 & 18.3 & & & 5.0 & 6.0 & 1.2 \\
\hline Mar-99 & 19.2 & 2.3 & 11.8 & 7480 & 0.24 & 16.4 & 35 & 93 & 3.5 & 8.0 & 2.8 \\
\hline Apr-99 & 26.4 & 3.1 & 11.9 & 7357 & 0.15 & 15.3 & 34.9 & & 4.7 & 4.4 & 0.9 \\
\hline Apr-99 & 24.0 & 2.6 & 10.8 & 7807 & 0.32 & 15 & 34.7 & & 4.7 & 6.0 & 1.3 \\
\hline May-99 & 18.8 & 2.6 & 13.8 & 14785 & 0.07 & 14.2 & 34.7 & 94.7 & 6.4 & 6.9 & 1.1 \\
\hline Jun-99 & 22.5 & 3.0 & 13.2 & & 0.09 & 14.6 & 34.7 & 91 & 6.9 & 5.1 & 0.9 \\
\hline Jul-99 & 13.4 & 1.8 & 13.4 & & 0.12 & & & & 6.9 & 3.9 & 0.6 \\
\hline Aug-99 & 27.2 & 3.5 & 12.7 & & 0.07 & 12.1 & 34.6 & & & & \\
\hline Sep-99 & 27.3 & 3.9 & 14.2 & & 0.03 & 12.5 & 35.3 & 98.7 & 8.5 & 7.1 & 0.8 \\
\hline Oct-99 & 21.5 & 2.7 & 12.7 & & 0.03 & 13 & 35.5 & 98.5 & & & \\
\hline
\end{tabular}

Table 4.3. Water characteristics from Inner Dorset during the time mussels were held at IBML for condition index experiments.

\begin{tabular}{|c|c|c|c|c|c|c|c|c|c|c|c|}
\hline & 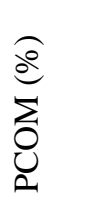 & $\begin{array}{l}\underset{I}{I} \\
\text { E } \\
\text { E } \\
\sum_{0} \\
0\end{array}$ & 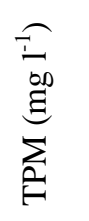 & 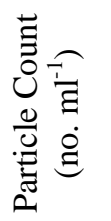 & 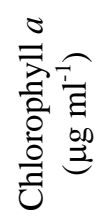 & 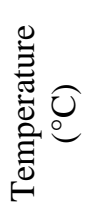 & 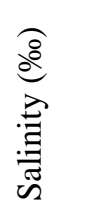 & 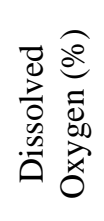 & ن & 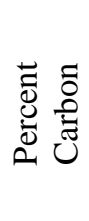 & 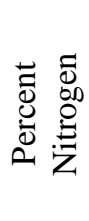 \\
\hline Nov-98 & 27.5 & 3.7 & 13.4 & 20389 & 0.43 & 15.8 & 33.1 & & 5.1 & 18.3 & 5.7 \\
\hline Dec-98 & & & & & 0.38 & & & & & & \\
\hline Jan-99 & 22.2 & 2.7 & 11.9 & 21390 & 0.60 & 18.1 & & & 5.5 & 19.3 & 3.5 \\
\hline Feb-99 & 26.3 & 3.7 & 13.9 & 35742 & 0.66 & 18.6 & & & 6.1 & 17.3 & 2.8 \\
\hline Mar-99 & 33.4 & 4.3 & 12.9 & 10912 & 0.61 & 18.3 & & & 5.4 & 12.4 & 2.3 \\
\hline Mar-99 & 19.5 & 2.6 & 13.3 & 7967 & 0.39 & 17.4 & 34.5 & 94.4 & 3.9 & 11.7 & 3.0 \\
\hline Apr-99 & 29.5 & 3.4 & 11.7 & 13947 & 0.48 & 16 & 34.6 & & 5.5 & 12.3 & 2.2 \\
\hline Apr-99 & 24.8 & 3.2 & 12.8 & 12887 & & 14.7 & 34.0 & & 5.4 & 12.7 & 2.3 \\
\hline May-99 & 19.4 & 2.4 & 12.2 & 14720 & 0.49 & 13.6 & 33.9 & 95.7 & 5.7 & 13.3 & 2.3 \\
\hline Jun-99 & 18.0 & 2.7 & 15.1 & 12482 & 0.21 & 14 & & 90.3 & 7.2 & 6.7 & 1.0 \\
\hline Jul-99 & 15.6 & 2.0 & 12.9 & & 0.15 & 11.4 & 33.9 & 56.2 & 6.4 & 11.2 & 1.7 \\
\hline Aug-99 & 24.0 & 3.2 & 13.3 & & 0.14 & 11.4 & 33.9 & & & & \\
\hline Sep-99 & 25.3 & 3.4 & 13.4 & & 0.39 & 12.5 & 34.3 & 105.2 & 5.7 & 24.2 & 4.3 \\
\hline Oct-99 & 25.0 & 2.9 & 11.4 & & 0.18 & 13.2 & 36.2 & 98.6 & & & \\
\hline
\end{tabular}


Pearson correlation analysis found that none of the correlations between condition and seston were significant in the Harbour or at IBML with the exception of condition and temperature in A. maoriana within the Harbour (Tables 4.4 \& 4.5). Condition and water temperature at Inner Dorset showed the strongest correlation of all the water sampling data (Fig. 4.4). Correlations were generally weaker at IBML, none being significant, but it should be noted that IBML correlations had fewer observations due to high mortality.

Table 4.4. Pearson correlations (n) between condition index and water characteristics at Harbour site, the only significant Bonferroni corrected correlation was between A. maoriana and temperature $(\mathrm{p}=0.045$, in bold).

\begin{tabular}{|c|c|c|c|c|c|c|c|c|c|c|}
\hline & 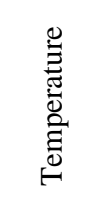 & $\begin{array}{l}\text { 悬 } \\
\text { 心 }\end{array}$ & $\sum_{\stackrel{\Theta}{\Theta}}$ & $\sum_{0}$ & $\begin{array}{l}\sum_{0} \\
\text { U }\end{array}$ & 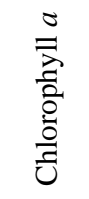 & 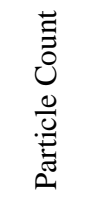 & 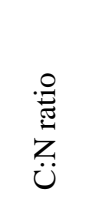 & 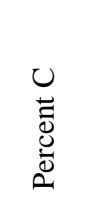 & 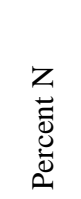 \\
\hline P. canaliculus CI & $\begin{array}{c}0.509 \\
(14)\end{array}$ & $\begin{array}{c}-0.45 \\
(11)\end{array}$ & $\begin{array}{c}0.072 \\
(14)\end{array}$ & $\begin{array}{c}0.510 \\
(14)\end{array}$ & $\begin{array}{c}0.487 \\
(14)\end{array}$ & $\begin{array}{c}0.351 \\
\text { (14) }\end{array}$ & $\begin{array}{c}0.488 \\
(7)\end{array}$ & $\begin{array}{c}-0.36 \\
(10)\end{array}$ & $\begin{array}{c}0.456 \\
(10)\end{array}$ & $\begin{array}{c}0.494 \\
(10)\end{array}$ \\
\hline A. maoriana CI & $\begin{array}{c}\mathbf{0 . 6 8 0} \\
(14)\end{array}$ & $\begin{array}{c}-0.15 \\
(11)\end{array}$ & $\begin{array}{c}0.053 \\
(14)\end{array}$ & $\begin{array}{c}0.371 \\
(14)\end{array}$ & $\begin{array}{c}0.351 \\
(14)\end{array}$ & $\begin{array}{c}0.480 \\
(14)\end{array}$ & $\begin{array}{c}0.283 \\
\text { (7) }\end{array}$ & $\begin{array}{c}-0.48 \\
(10)\end{array}$ & $\begin{array}{c}0.116 \\
(10)\end{array}$ & $\begin{array}{c}0.220 \\
(10)\end{array}$ \\
\hline M. galloprovincialis CI & $\begin{array}{c}0.507 \\
(14)\end{array}$ & $\begin{array}{c}-0.25 \\
(11)\end{array}$ & $\begin{array}{c}-0.19 \\
(14)\end{array}$ & $\begin{array}{c}0.592 \\
(14)\end{array}$ & $\begin{array}{c}0.664 \\
(14)\end{array}$ & $\begin{array}{c}0.395 \\
(14)\end{array}$ & $\begin{array}{c}0.181 \\
(7)\end{array}$ & $\begin{array}{c}-0.67 \\
(10)\end{array}$ & $\begin{array}{c}0.391 \\
(10)\end{array}$ & $\begin{array}{c}0.508 \\
(10)\end{array}$ \\
\hline
\end{tabular}

Table 4.5. Pearson correlations (n) between condition index and water characteristics at IBML, none of these correlations had Bonferroni corrected probabilities $<0.01$.

\begin{tabular}{|c|c|c|c|c|c|c|c|c|c|c|}
\hline & 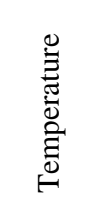 & 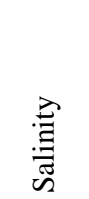 & 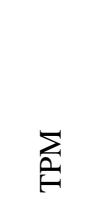 & $\sum_{0}$ & 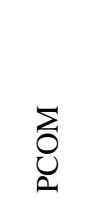 & 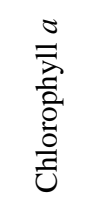 & 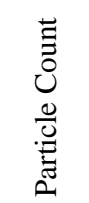 & 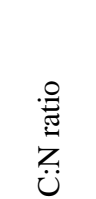 & $\begin{array}{l}u \\
\vec{\Xi} \\
\text { Uूँ } \\
\text { م. }\end{array}$ & 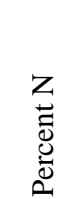 \\
\hline P. canaliculus $C I$ & $\begin{array}{c}-0.31 \\
(7)\end{array}$ & $\begin{array}{c}0.829 \\
\text { (4) }\end{array}$ & $\begin{array}{c}0.00 \\
(7)\end{array}$ & $\begin{array}{c}0.256 \\
(7)\end{array}$ & $\begin{array}{c}0.282 \\
\text { (7) }\end{array}$ & $\begin{array}{c}-0.33 \\
(7)\end{array}$ & $\begin{array}{c}-0.13 \\
(7)\end{array}$ & $\begin{array}{c}0.091 \\
(7)\end{array}$ & $\begin{array}{c}0.202 \\
\text { (7) }\end{array}$ & $\begin{array}{c}0.065 \\
(7)\end{array}$ \\
\hline A. maoriana CI & $\begin{array}{c}0.465 \\
(11)\end{array}$ & $\begin{array}{c}-0.10 \\
(8)\end{array}$ & $\begin{array}{c}0.125 \\
(12)\end{array}$ & $\begin{array}{c}0.057 \\
(12)\end{array}$ & $\begin{array}{c}-0.03 \\
(12)\end{array}$ & $\begin{array}{c}0.175 \\
(12)\end{array}$ & $\begin{array}{c}0.127 \\
\text { (7) }\end{array}$ & $\begin{array}{c}-0.29 \\
(11)\end{array}$ & $\begin{array}{c}0.626 \\
(11)\end{array}$ & $\begin{array}{c}0.493 \\
(11)\end{array}$ \\
\hline M. galloprovincialis CI & $\begin{array}{c}-0.38 \\
(7)\end{array}$ & $\begin{array}{c}0.589 \\
\text { (4) }\end{array}$ & $\begin{array}{c}0.132 \\
(7)\end{array}$ & $\begin{array}{c}0.134 \\
(7)\end{array}$ & $\begin{array}{c}-0.08 \\
(7)\end{array}$ & $\begin{array}{c}-0.68 \\
(7)\end{array}$ & $\begin{array}{c}0.107 \\
(7)\end{array}$ & $\begin{array}{c}0.448 \\
(7)\end{array}$ & $\begin{array}{c}0.475 \\
(7)\end{array}$ & $\begin{array}{c}0.00 \\
(7)\end{array}$ \\
\hline
\end{tabular}

It has been observed that growth of Mytilus edulis can experience a 2-4 wk lag behind chlorophyll a levels (Page \& Hubbard, 1987). A time series analysis was not conducted as only fifteen data points are compared; such an analysis requires larger data sets. A cross correlation analysis was used to identify at which lag interval the correlation was strongest. For all species, the best correlation was observed when no 
lag was used; the second strongest correlation in all species was a lag of one month (Fig. 4.5).
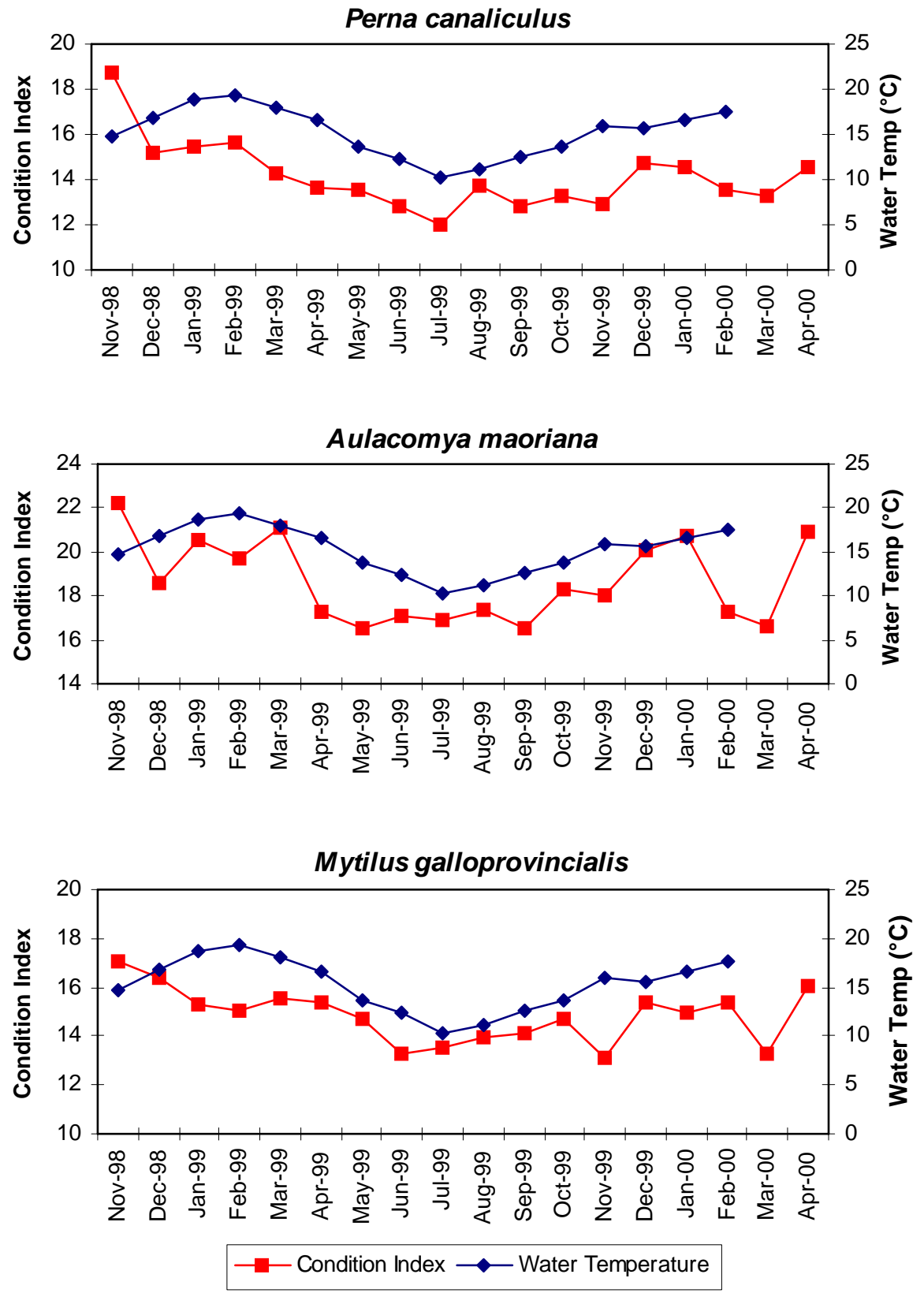

Figure 4.4. Relationship between the condition index of all three species of mussels from, Wellington Harbour and water Temperature at the closet Harbour water sampling site, Inner Dorset. 

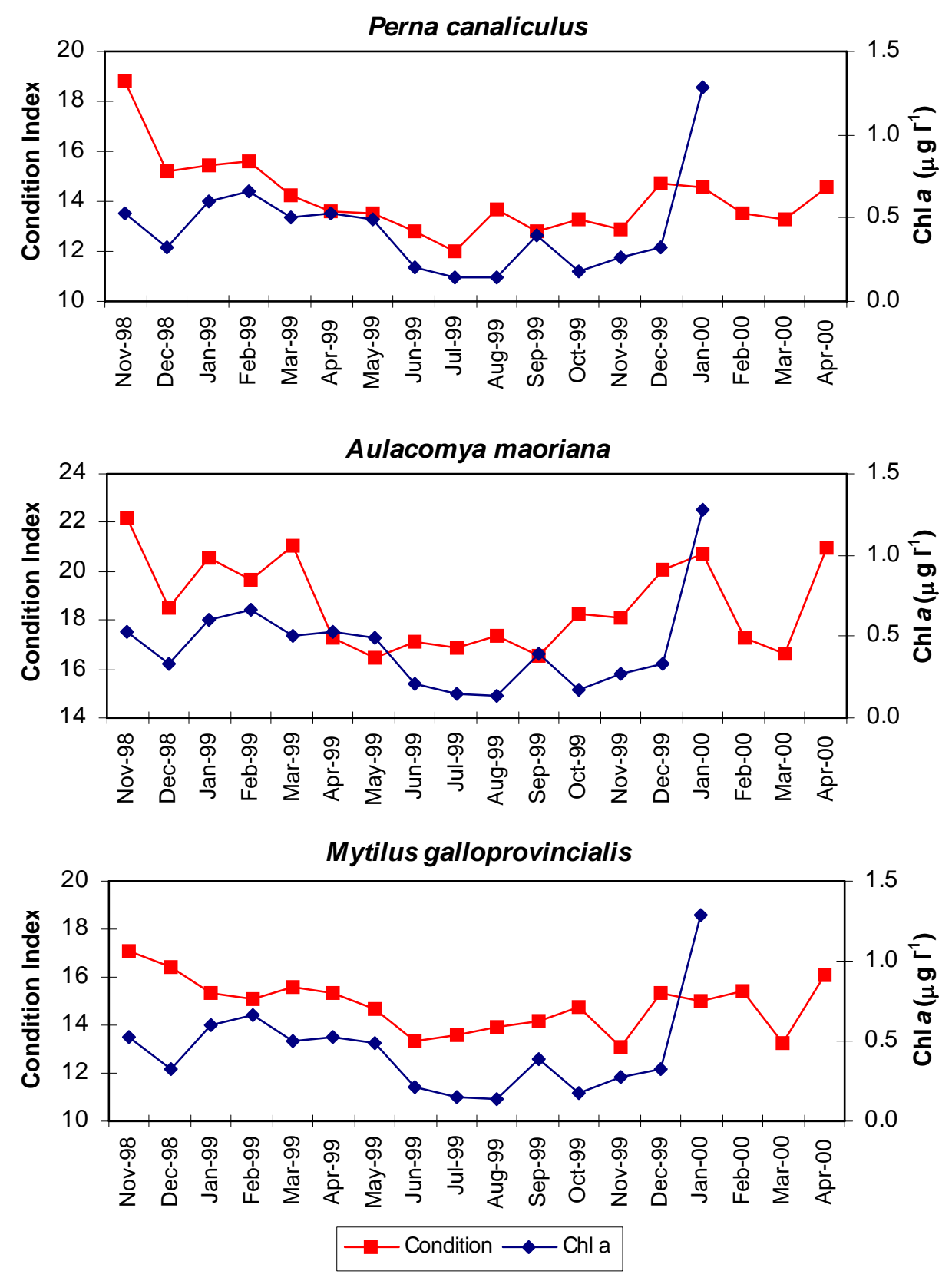

Figure 4.5. Relationship between the condition index of all three species of mussels from, Wellington Harbour and chlorophyll $a$ at the closet Harbour water sampling site, Inner Dorset.

\subsubsection{Second condition experiment}

As with the first experiment, all three mussel species held at IBML experienced a decrease in condition over the initial sampling period (Fig. 4.6). The magnitude of the decrease in condition index is smaller than in the first experiment. The separation of the lines however is accentuated by an increase in condition of Harbour samples between October 1999 and January 2000. None of the species held at IBML showed a corresponding increase over the same period. 

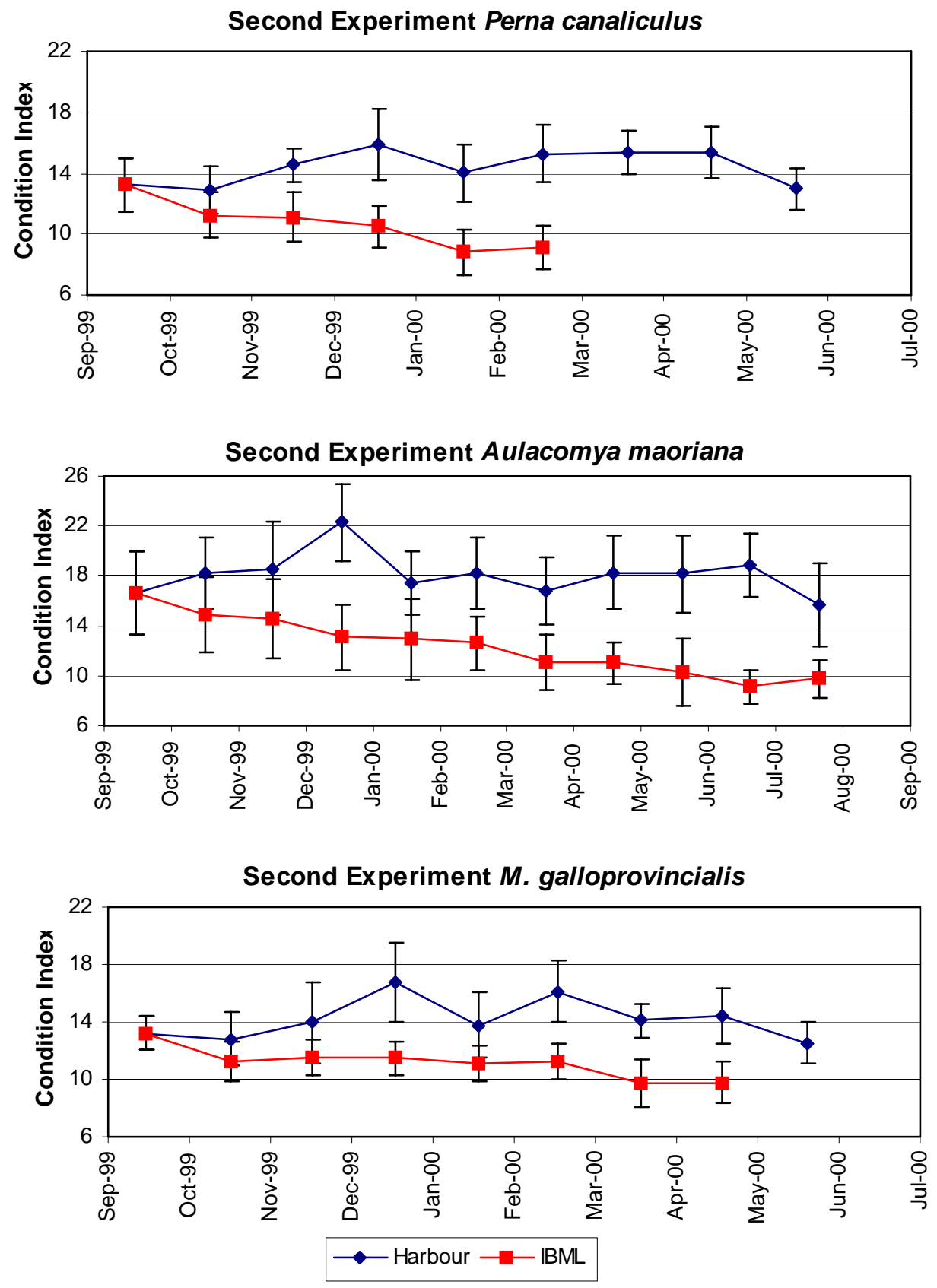

Figure 4.6. Second experiment. Comparison of condition in all three species between a Harbour population and individuals from the same population transferred to IBML (mean $\pm S D, n=20$ ).

\section{Statistical Analysis - P. canaliculus}

An ANOVA was performed on raw data to test for differences in condition index between sites, months and for the month * site interaction. All terms were significant ( $p<0.001$, site $F=96.57$, month $F=6.62$, interaction $F=12.00$ ) and the full model was accepted $\left(\mathrm{p}<0.001, \mathrm{~F}=42.28, \mathrm{R}^{2}=0.818, \mathrm{n}=220\right)$. 


\section{A. maoriana}

An ANOVA of the raw data showed significant differences in condition index between months, sites and the month * site interaction $(\mathrm{p}<0.001$, month $\mathrm{F}=7.30$, site $F=38.97$, interaction $F=5.15)$. The full model was accepted $\left(p<0.001, F=27.645, R^{2}=\right.$ 0.578, $\mathrm{n}=340)$.

\section{M. galloprovincialis}

As with the other two species, an ANOVA on the raw data for M. galloprovincialis also showed significant differences in condition index between month, site and month * site interaction $(\mathrm{p}<0.001$, month $\mathrm{F}=8.39$, site $\mathrm{F}=57.28$, interaction $\mathrm{F}=6.35)$. As such the full model was accepted $\left(\mathrm{p}<0.001, \mathrm{~F}=26.87, \mathrm{R}^{2}=0.574, \mathrm{n}=294\right)$.

\subsubsection{Mortalities}

The rate of mortality was high in both experiments, especially for $P$. canaliculus and M. galloprovincialis. The total number of mortalities was calculated for each species as a proportion of all animals collected (i.e. mortalities + experimental animals). In the first experiment $P$. canaliculus experienced an overall mortality rate of $64 \%, A$. maoriana 26\% and M. galloprovincialis $70 \%$. The results of the second experiment are very similar, $P$. canaliculus experienced 59\% mortality, $A$. maoriana $31 \%$ and $M$. galloprovincialis 70\% (Fig. 4.7).

These figures show very little difference between mortality in P. canaliculus and $M$. galloprovincialis. In the first experiment it appears that $P$. canaliculus suffers an increase in mortality a month prior to M. galloprovincialis, however this is not as pronounced in the second experiment. In both experiments mortality in A. maoriana remains constant throughout. 

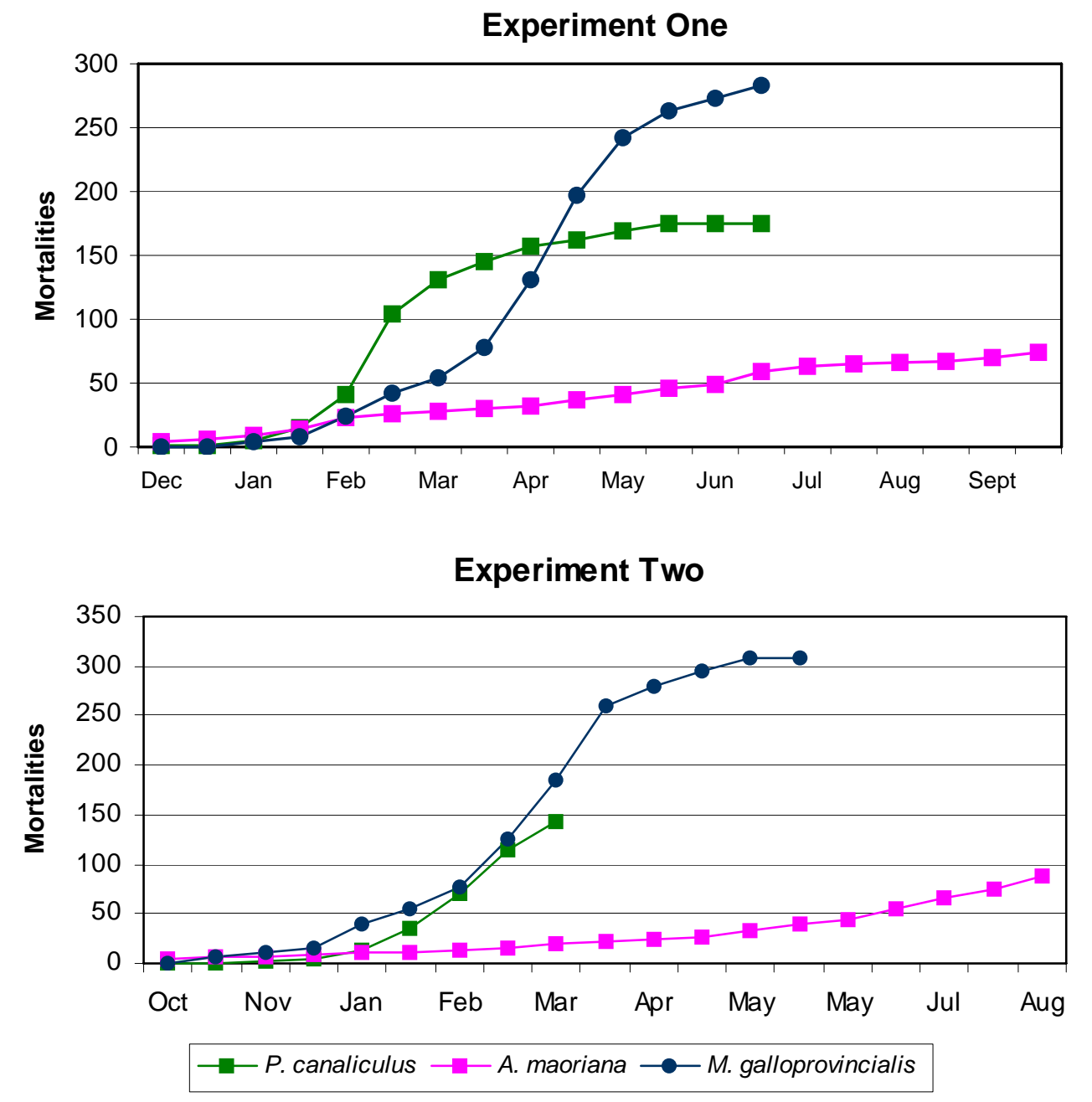

Figure 4.7. Cumulative fortnightly mortalities of mussels held at IBML during both condition index experiments, mortalities are expressed as the proportion all animals collected (i.e. mortalities + experimental animals).

\subsubsection{Gonad mass}

\section{P. canaliculus}

Length standardised gonad mass in P. canaliculus shows a high level of within-month variation as seen by the relative size of the error bars (Fig. 4.8). Unlike similar data comparing condition index between sites there appears to be a less pronounced variation between Harbour and IBML for gonad mass data. 


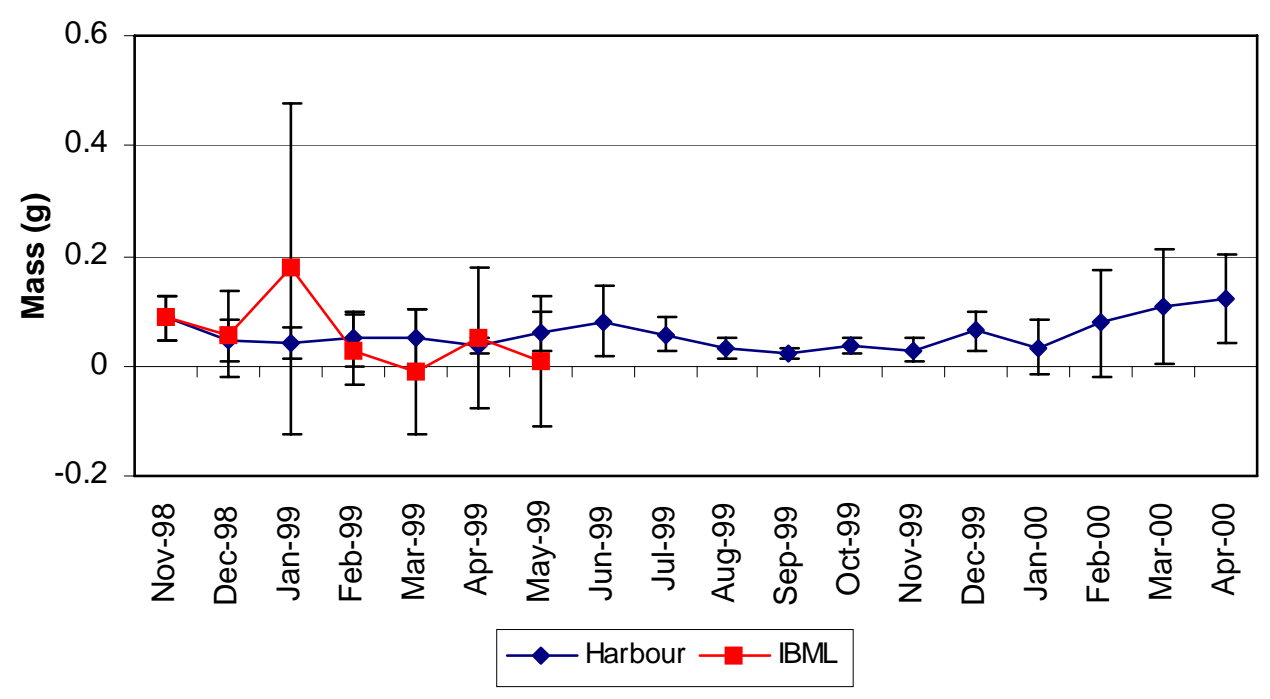

Figure 4.8. Comparative gonad mass in P. canaliculus between Harbour site and Harbour mussels held at IBML (mean \pm SD, $\mathrm{n}=20)$.

There appears to be no significant peaks in gonad mass over the sampled period with the possible exception of late summer in 2000. Again, this should be interpreted with caution due to the high variation within samples. Due to the large number of animals that were recorded with no gonad tissue, the data did not conform to assumptions necessary for an ANOVA. A non-parametric Kruskal-Wallis test produced a MannWhitney $\mathrm{U}$ test statistic of $4070.5(\mathrm{p}<0.001)$. This result seems curious, as after an examination of Figure 4.8, one would expect a non-significant result. A Welch modified t-test for samples with unequal variance was attempted $(\mathrm{p}=0.48)$, however, assumptions of normality of distribution failed due to outliers. Thus the MannWhitney $\mathrm{U}$ test statistic must be used. This apparent anomaly is most likely because non-parametric tests work on a ranking basis, rather than taking variance into account as in parametric tests.

\section{A. maoriana}

Gonad mass in A. maoriana was greater than in both other species (Table 4.6) (Fig. 4.9). Temporal variation in gonad mass showed only small variations among months. Decrease in gonad mass may indicate spawning events in the period between November and December 1998 and again between September and November 1999. 


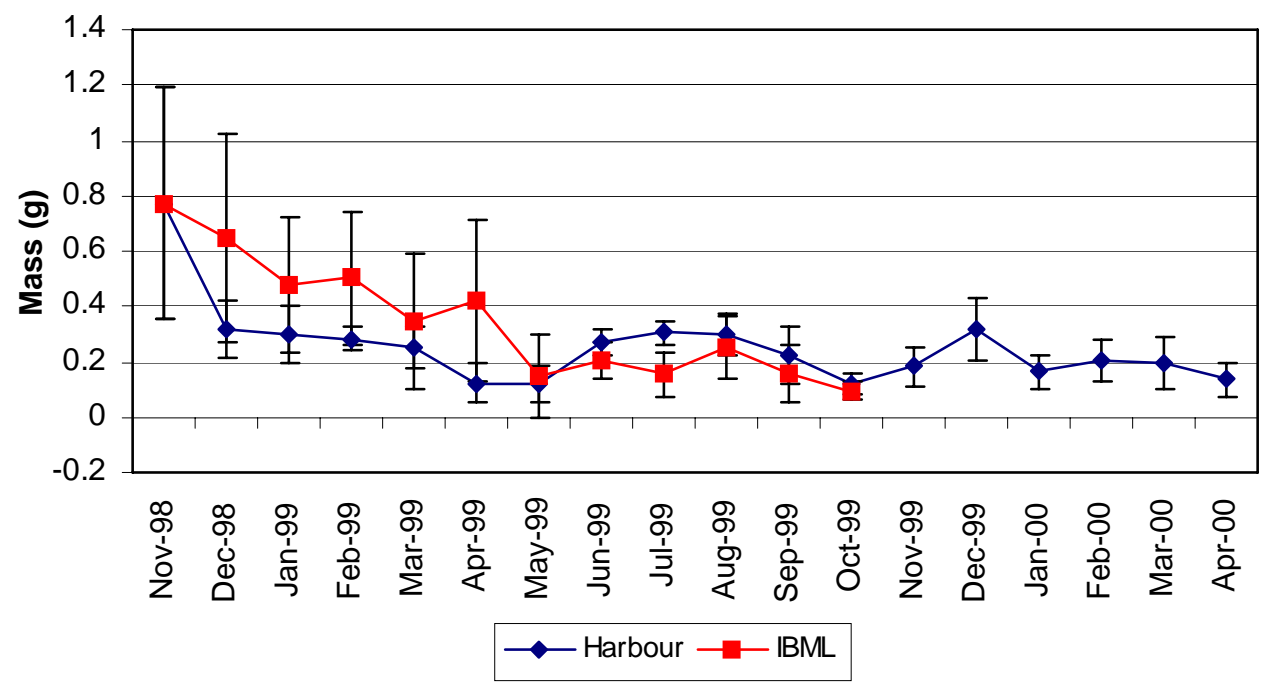

Figure 4.9. Comparative gonad mass in A. maoriana between Harbour site and Harbour mussels held at IBML (mean \pm SD, $\mathrm{n}=20)$.

A step-wise ANOVA on the logged data showed significant differences between months, and the site * month interaction (month $\mathrm{p}<0.001, \mathrm{~F}=4.763$; interaction $\mathrm{p}<0.001, \mathrm{~F}=4.462$ ). Site did not explain significant variation in gonad mass ( $\mathrm{p}=0.091$, $\mathrm{F}=2.864$ ), although mass was greater at the Harbour site. There appeared to be no clear separation between mussels held at IBML and those collected from the Harbour. While both populations showed a decrease in gonad mass, those held at IBML initially decreased more slowly.

\section{M. galloprovincialis}

Temporal variation in the gonad mass of Harbour mussels showed a decrease between December 1998 and January 1999, and another larger decrease was seen between October and December 1999 (Fig. 4.10). Gonad mass increases after the December 1999 minimum to a peak in March 2000. Gonad mass in M. galloprovincialis appeared to decrease in IBML animals gradually throughout the study (Fig. 4.10). As with the other two species, M. galloprovincialis showed high levels of variation within months. A step-wise ANOVA on the logged data showed that gonad mass was significantly different between sites, months and for the site * month interaction (site, $\mathrm{p}=0.004, \mathrm{~F}=8.349$; month, $\mathrm{p}<0.001, \mathrm{~F}=6.595$; interaction, $\mathrm{p}<0.001, \mathrm{~F}=24.753$ ), and subsequently the full model is accepted $\left(\mathrm{p}<0.001, \mathrm{~F}=21.029, \mathrm{R}^{2}=0.521, \mathrm{n}=469\right)$. Four large outliers were identified and removed and the test was repeated $\left(\mathrm{R}^{2}=0.932\right)$. In this analysis, month and the interaction term were significant, however, site is now 
highly non-significant (month, $\mathrm{p}<0.001, \mathrm{~F}=52.769$; interaction, $\mathrm{p}<0.001, \mathrm{~F}=501.694$; site, $\mathrm{p}=0.521, \mathrm{~F}=0.413)$.

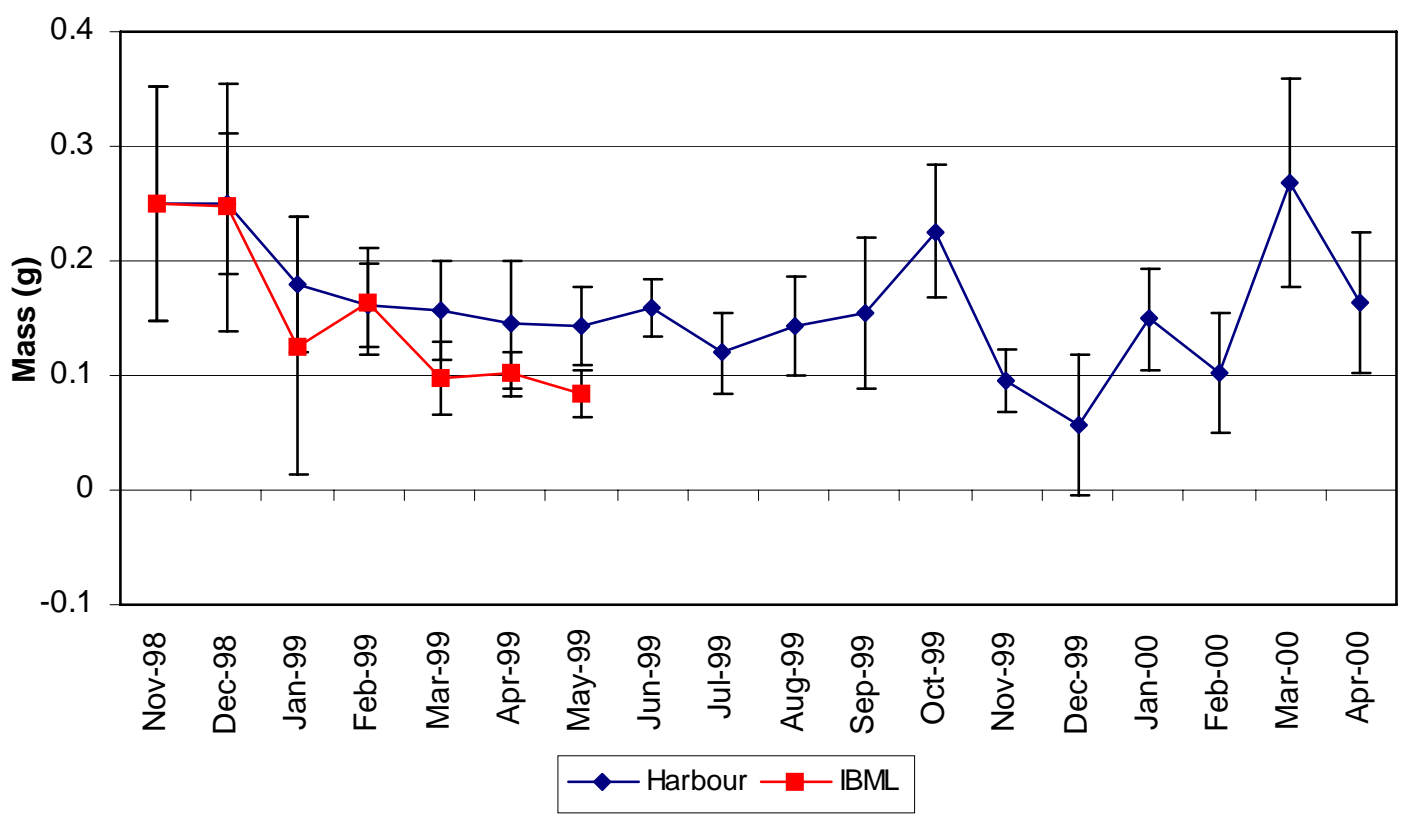

Figure 4.10. Comparative gonad mass in M. galloprovincialis between Harbour site and Harbour mussels held at IBML (mean \pm SD, $\mathrm{n}=20$ ).

Gonad tissue was found in all species all year round (Figs. 4.8-4.10). In any given month, gonad mass varied considerably among individuals of all three species. The difference in gonad mass between sites was not as evident as differences in condition index between sites. Mean gonad mass was not greater at the Harbour site, but variation was noticeably increased within species held at IBML (Table 4.6). Gonad mass was monitored in Harbour mussels for 18 months, but due to high mortality among IBML mussels, fewer data were gathered. Because of this, only Harbour data were used to compare with IBML in Table 4.6 if they had a corresponding observation at IBML.

Table 4.6. Comparison of mean monthly gonad mass (g), mean monthly SD and coefficient of variation (CV) between Harbour and IBML. Only Harbour months were used when they had comparable data from IBML.

\begin{tabular}{l|cccccc}
\hline & \multicolumn{3}{|c}{ Harbour } & \multicolumn{3}{c}{ IBML } \\
\cline { 2 - 7 } & Mean & SD & CV & Mean & SD & CV \\
A. canaliculus & 0.053 & 0.037 & 0.698 & 0.057 & 0.120 & 2.150 \\
M. galloprana & 0.135 & 0.079 & 0.585 & 0.141 & 0.162 & 1.135 \\
\hline
\end{tabular}




\subsubsection{Pea crab Infestations}

The pea crab (Pinnotheres novaezelandiae) had been observed in a number of animals over the course of this study. The infestation of pea crabs has been recorded in many shellfish species, and the relationship is generally accepted as being parasitic. Tablado and Gappa (1995), while studying the pea crab Tumidotheres maculatus in Mytilus edulis, found mussel length and dry meat weight to be significantly lower when animals were parasitised by mature female crabs, but not smaller females or males. This is presumably because the small size of the males allowed them to feed independently outside the mussel host. This was found to be the case in studies of Pinnotheres tsingtaoensis infestations of Sanguinolaria actuta (Soong, 1997) and Pinnotheres pisum infestation of Mytilus edulis (Haines et al., 1994). A study by O’Beirn and Walker (1999) of infestation by Pinnotheres ostreum of Crassostrea virginica found no difference in gonad area between oysters with and without pea crabs at a site where infestation was low. However, at a second site where the rate of pea crab infestation was higher, oysters with pea crabs had a significantly lower gonad area than those without. Bierbaum and Ferson (1986) studied the effect of Pinnotheres maculatus on the growth rate of Mytilus edulis. The rate of shell length increase between mussels with and without crab infestation was compared after transplantation from an initial site to two experimental sites, a low nutrient and high nutrient site. It was found that at the low nutrient site growth was significantly reduced, while no such reduction was observed at the high nutrient site. When mussels were taken from the initial population, significant shell shape distortion characteristic of reduced growth rate was found in mussels harbouring pea crabs compared to those without. Hickman (1978) studied infestation by Pinnotheres novaezealandiae in a large number of Perna canaliculus, and concluded that condition was not significantly affected by infestation.

Tests were performed on each mussel species in order to ascertain whether those mussels containing pea crabs showed a lower condition index. The pea crabs infesting mussels in this study ranged significantly in size and mass (Table 4.7). All comparisons between animals with and without crabs were made within sites as condition was shown to vary between sites. In order to increase sample sizes, data from condition index experiment one and two were combined. 
Table 4.7. Mass and carapace width of pea crabs.

\begin{tabular}{l|cccc}
\hline & \multicolumn{2}{|c}{ Experiment One } & \multicolumn{2}{c}{ Experiment Two } \\
\hline & $\begin{array}{c}\text { Dry Weight } \\
(\mathrm{g})\end{array}$ & $\begin{array}{c}\text { Carapace Width } \\
(\mathrm{mm})\end{array}$ & $\begin{array}{c}\text { Dry Weight } \\
(\mathrm{g})\end{array}$ & $\begin{array}{c}\text { Carapace Width } \\
(\mathrm{mm})\end{array}$ \\
\hline Mean & 0.1032 & 7.5 & 0.1609 & 6.4 \\
SD & 0.0782 & 3.7 & 0.0978 & 4.1 \\
Minimum & 0.0145 & 4 & 0.0119 & 3 \\
Maximum & 0.2897 & 15 & 0.3662 & 3 \\
\hline
\end{tabular}

\section{P. canaliculus}

In Harbour animals, of the 478 mussels used in this analysis, 25 were observed with pea crab infestations. The condition was lower in those mussels that had pea crabs (Table 4.8) and ANOVA showed a significant difference in condition between these groups $(\mathrm{p}=0.002, \mathrm{~F}=9.595)$.

In IBML animals, of the 197 mussels used in this analysis, 17 had pea crab infestations. The mean condition was essentially the same in mussels with and without pea crabs (Table 4.9). ANOVA showed no significant difference in condition between groups ( $\mathrm{p}=0.768, \mathrm{~F}=0.088)$.

Table 4.8. Least squares means comparison of Condition Index of mussel species with and without pea crab infestation from the Harbour.

\begin{tabular}{l|ccccccc}
\hline & \multicolumn{3}{|c}{ Without Pea Crab } & \multicolumn{3}{c}{ With Pea Crab } & p-value \\
\hline & Mean CI & S.E. & $\mathrm{n}$ & Mean CI & S.E. & $\mathrm{n}$ & \\
P. canaliculus & 14.27 & 0.11 & 453 & 12.77 & 0.47 & 25 & 0.002 \\
A. maoriana & 18.63 & 0.16 & 508 & 15.11 & 1.12 & 11 & 0.002 \\
M. galloprovincialis & 14.72 & 0.11 & 513 & 13.87 & 0.99 & 6 & 0.393 \\
\hline
\end{tabular}

\section{A. maoriana}

The Harbour mussels had 11 pea crab infestations of 519 mussels. ANOVA showed that mussels with pea crabs had a significantly lower condition index than those without (Table 4.8) ( $\mathrm{p}=0.002, \mathrm{~F}=9.752)$.

Of the 349 mussels held at IBML, only 10 were found to have pea crabs. The condition of mussels with pea crabs was lower than those without (Table 4.9), however, an ANOVA showed this difference not to be significant ( $p=0.759, F=0.094)$. 
Table 4.9. Least squares means comparison of Condition Index of mussel species with and without pea crab infestation from IBML population.

\begin{tabular}{l|ccccccc}
\hline & \multicolumn{6}{|c}{ Without Pea Crab } & \multicolumn{3}{c}{ With Pea Crab } & p-value \\
\hline & Mean CI & S.E. & $\mathrm{n}$ & Mean CI & S.E. & $\mathrm{n}$ & \\
P. canaliculus & 10.91 & 0.16 & 180 & 11.07 & 0.53 & 17 & 0.768 \\
A. maoriana & 13.54 & 0.24 & 339 & 13.10 & 1.41 & 10 & 0.759 \\
M. galloprovincialis & 11.72 & 0.14 & 249 & 13.43 & 0.92 & 6 & 0.066 \\
\hline
\end{tabular}

\section{M. galloprovincialis}

The mussels from the Harbour contained only six pea crabs of the 519 mussels in the experiment. The condition of infested mussels was lower (Table 4.8) although an ANOVA showed that this difference was not significant ( $\mathrm{p}=0.393, \mathrm{~F}=0.729)$.

Of the 255 mussels analysed from IBML, six were found to have pea crab infestations. Curiously those infested had a higher condition index than those without pea crabs (Table 4.9). An ANOVA showed that those infested were not in significantly better condition $(\mathrm{p}=0.066, \mathrm{~F}=3.403)$.

\section{Summary}

Levels of mussel infestation vary markedly in the literature (Table 4.10). This study, whilst having a relatively small sample size, found infestation rates equivalent to those of Hickman (1978). As this study is the most pertinent in terms of study site and species, this is not unexpected. Unlike Hickman (1978), these data show lower condition in $P$. canaliculus when infested with $P$. novaezelandiae. Hickman (1978) used a sample of 6956 animals from seven sites, compared to 633 in this study. Hickman also used mussels from raft populations at all but one site. It may be that raft populations stop re-infestation of smaller crabs that leave mussels, while many of the larger crabs are unlikely to be able to leave mussel shells. Condition decrease was also seen in A. maoriana from the Harbour, although a similar decrease was not detected in M. galloprovincialis. No significant differences were found between infested and non-infested mussels at IBML. P. canaliculus had similar condition between groups and A. maoriana showed a decrease in infested mussels. However, $M$. galloprovincialis had a higher condition in the six infested mussels found. As discussed in Section 4.2, mussels held at IBML were losing condition; as a consequence, comparisons between infested and non-infested mussels at IBML may be obscured by the decrease in condition due to site relocation. 
Table 4.10. Comparison of pea crab infestation rates from various studies.

\begin{tabular}{|c|c|c|c|c|}
\hline Host species & Crab species & Site & Infestation rate & Study \\
\hline Perna canaliculus & $\begin{array}{l}\text { Pinnotheres } \\
\text { novaezelandiae }\end{array}$ & Wellington, NZ & $\begin{array}{l}\text { Range } 0-12 \% \\
\text { Mean } 1-2 \%\end{array}$ & Hickman, 1978 \\
\hline Perna canaliculus & $\begin{array}{l}\text { Pinnotheres } \\
\text { novaezelandiae }\end{array}$ & Wellington, NZ & $39 \%$ & $\begin{array}{l}\text { Jones, } 1975 \text { \& } \\
1977\end{array}$ \\
\hline Mytilus edulis & $\begin{array}{l}\text { Tumidotheres } \\
\text { maculatus }\end{array}$ & SW Atlantic & $\begin{array}{l}\text { Range 54.3-72.6 } \\
\text { Mean } 63.6\end{array}$ & $\begin{array}{l}\text { Tablado \& Gappa, } \\
1995\end{array}$ \\
\hline Mactra discors & $\begin{array}{l}\text { Pinnotheres } \\
\text { novaezelandiae }\end{array}$ & NW Wellington & $92.9 \%$ & Palmer, 1995 \\
\hline $\begin{array}{l}\text { Mactra } \\
\text { murchisoni }\end{array}$ & $\begin{array}{l}\text { Pinnotheres } \\
\text { novaezelandiae }\end{array}$ & NW Wellington & $7.4 \%$ & Palmer, 1995 \\
\hline $\begin{array}{l}\text { Spisula } \\
\text { aequilateralis }\end{array}$ & $\begin{array}{l}\text { Pinnotheres } \\
\text { novaezelandiae }\end{array}$ & NW Wellington & $26.7 \%$ & Palmer, 1995 \\
\hline Paphies donacina & $\begin{array}{l}\text { Pinnotheres } \\
\text { novaezelandiae }\end{array}$ & NW Wellington & None & Palmer, 1995 \\
\hline Dosinia anus & $\begin{array}{l}\text { Pinnotheres } \\
\text { novaezelandiae }\end{array}$ & NW Wellington & None & Palmer, 1995 \\
\hline $\begin{array}{l}\text { Sanguinolaria } \\
\text { actuta }\end{array}$ & $\begin{array}{l}\text { Pinnotheres } \\
\text { tsingtaoensis }\end{array}$ & W Taiwan & $>90 \%$ & Soong, 1997 \\
\hline $\begin{array}{l}\text { Crassostrea } \\
\text { virginica }\end{array}$ & $\begin{array}{l}\text { Pinnotheres } \\
\text { ostreum }\end{array}$ & $\begin{array}{l}\text { Wassaw Sound, } \\
\text { Georgia }\end{array}$ & $1-8 \%$ & $\begin{array}{l}\text { O’Beirn \& } \\
\text { Walker, } 1999\end{array}$ \\
\hline Mytilus edulis & $\begin{array}{l}\text { Pinnotheres } \\
\text { maculatus }\end{array}$ & $\begin{array}{l}\text { Gay Head, } \\
\text { Massachusetts }\end{array}$ & $69 \%$ & $\begin{array}{l}\text { Bierbaum \& } \\
\text { Ferson, } 1986\end{array}$ \\
\hline Perna canaliculus & $\begin{array}{l}\text { Pinnotheres } \\
\text { novaezelandiae }\end{array}$ & Wellington, NZ & $\begin{array}{l}\text { Exp. 1. } 2.6 \% \\
\text { Exp. 2. } 13.6 \%\end{array}$ & This study \\
\hline $\begin{array}{l}\text { Aulacomya } \\
\text { maoriana }\end{array}$ & $\begin{array}{l}\text { Pinnotheres } \\
\text { novaezelandiae }\end{array}$ & Wellington, NZ & $\begin{array}{l}\text { Exp. 1. } 1.6 \% \\
\text { Exp. 2. } 4.0 \%\end{array}$ & This study \\
\hline $\begin{array}{l}\text { Mytilus } \\
\text { galloprovincialis }\end{array}$ & $\begin{array}{l}\text { Pinnotheres } \\
\text { novaezelandiae }\end{array}$ & Wellington, NZ & $\begin{array}{l}\text { Exp. } 1.1 .9 \% \\
\text { Exp. 2. } 1.0 \%\end{array}$ & This study \\
\hline
\end{tabular}

\subsubsection{RNA:DNA analysis}

The tissue samples used for the analysis were of a relatively constant mass for each species; P. canaliculus, mean $10.8 \mathrm{~g}( \pm 0.34)$, A. maoriana, mean $6.9 \mathrm{~g}( \pm 0.25)$ and $M$. galloprovincialis, mean $9.0 \mathrm{~g}( \pm 0.33)$. Data were therefore not weight standardised to tissue sample mass in this analysis as there is no basis for the assumption that similar mass tissues contain similar numbers of cells and was thought that differential water retention in the tissues was a source of substantial error. In addition to this, the ratio of RNA to DNA is of interest and this will not be affected by weight standardisation of samples. Variation in RNA and DNA levels was minimal in mussels from Kau Bay (Fig 4.11). In the Kau Bay samples there were small variations of RNA in $A$. maoriana and M. galloprovincialis, while $P$. canaliculus remained relatively constant. The ratio of RNA to DNA showed a little more variation, more so in A. maoriana and M. galloprovincialis. The general trend in Kau Bay mussels however, was that the ratio remained at a similar level throughout the duration of the study. Animals held at IBML however did not show the same pattern. DNA levels in all species were 
relatively constant but showed more variation over time than those animals from Kau Bay (Fig 4.11). More variation was also seen in RNA; all species held at IBML showed a trend of decreasing RNA levels over the course of the study. The ratio of RNA to DNA in IBML mussels also differed compared to those from Kau Bay.
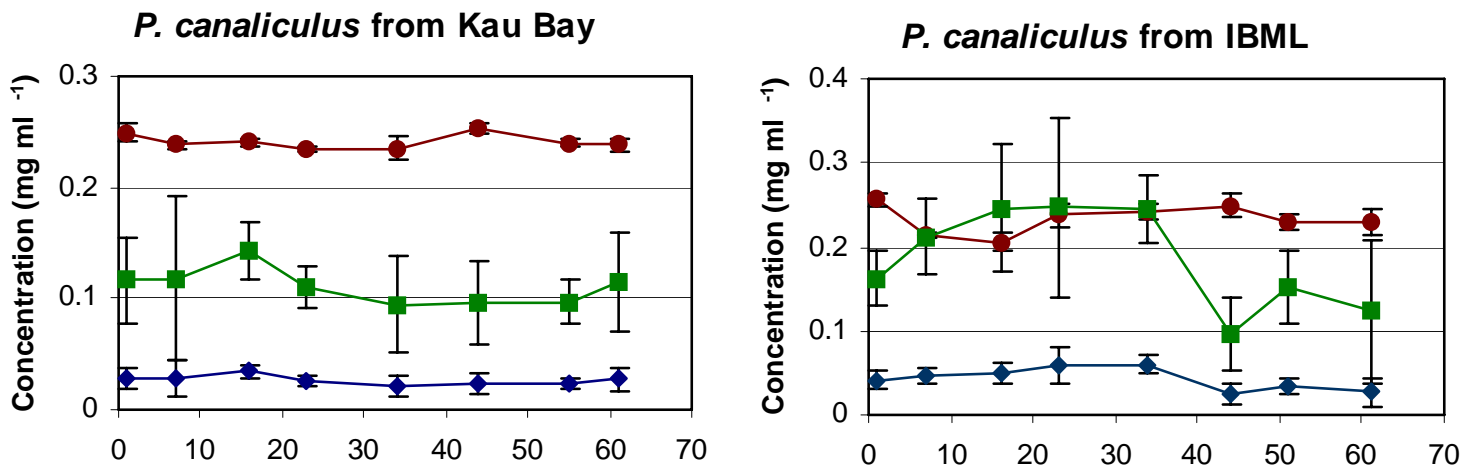

A. maoriana from Kau Bay

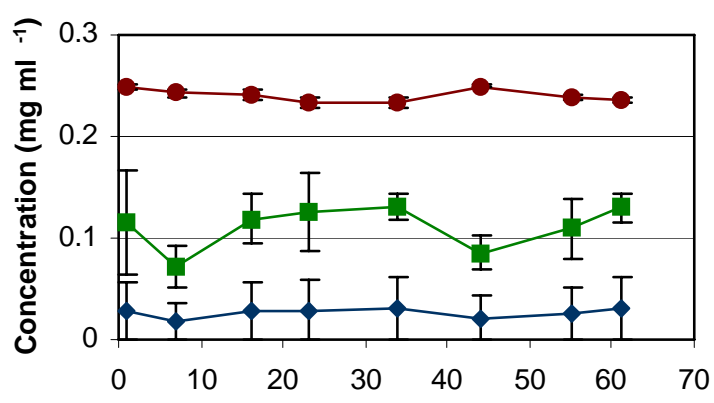

A. maoriana from IBML

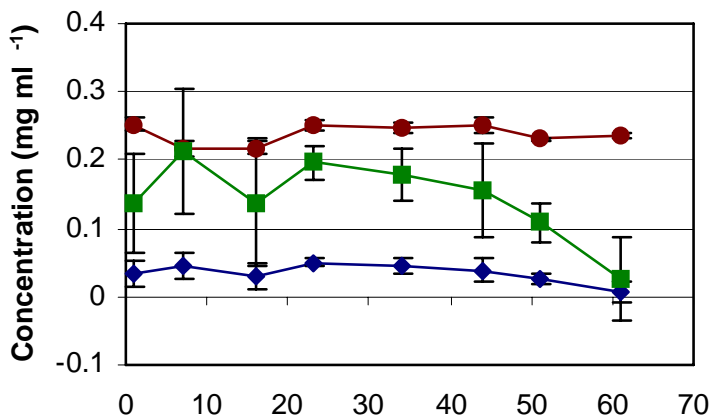

M. galloprovincialis from Kau Bay

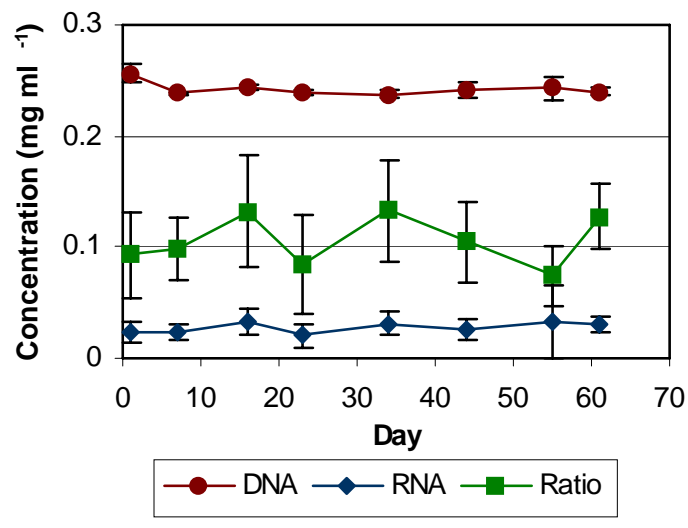

M. galloprovincialis from IBML

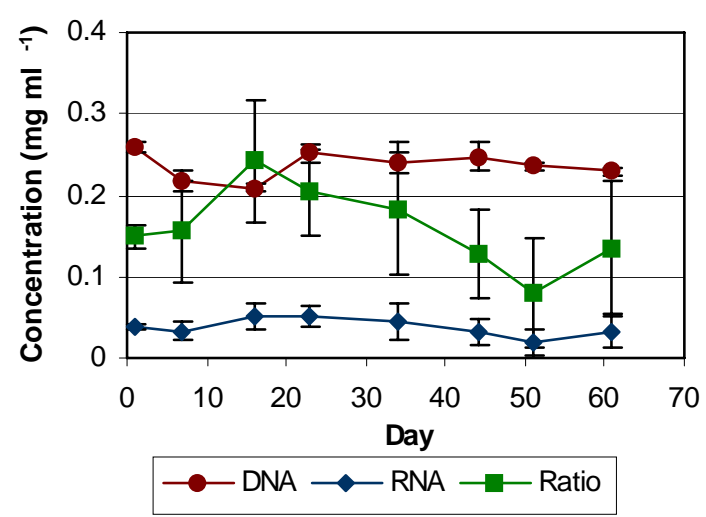

Figure 4.11. Concentrations of DNA, RNA and RNA:DNA ratio for all species from Kau Bay (left) and those from Kau Bay held at IBML (right), points are the mean of five observations.

Mussels from IBML show a moderate degree of fluctuation over time, although the overall trend is a decrease in RNA:DNA ratio. This is particularly evident in A. maoriana where the last four weeks showed a constant downward trend in RNA:DNA 
ratio (Fig. 4.11). M. galloprovincialis also showed a strong downward trend toward the end of the experiment, although this may be obscured by a sharp rise in the third week and the final week. $P$. canaliculus showed a similar trend to $M$. galloprovincialis; a small rise in ratio occurred over the initial two weeks followed by a decline toward the end of the experiment (Fig. 4.11). Levels of RNA and RNA:DNA were consistently higher at IBML than at Kau Bay (Table 4.11). Variation in RNA, DNA and RNA:DNA is consistently higher at IBML compared to Kau Bay (Table 4.11).

Table 4.11. Summary of RNA ( $\left.\mathrm{mg} \mathrm{ml}^{-1}\right)$, DNA ( $\mathrm{mg} \mathrm{ml}^{-1}$ ) and RNA:DNA ratio of mussels from Kau Bay and Island Bay Marine Lab (IBML). Data are the means, standard deviations (SD) and coefficient of variation $(\mathrm{CV})$ of forty observations.

\begin{tabular}{l|cccccccccc}
\hline & Site & \multicolumn{4}{c}{ RNA } & \multicolumn{4}{c}{ DNA } & \multicolumn{4}{c}{ RNA:DNA } \\
& & Mean & SD & CV & Mean & SD & CV & Mean & SD & CV \\
P. canaliculus & Kau Bay & 0.027 & 0.010 & 0.370 & 0.241 & 0.008 & 0.033 & 0.111 & 0.040 & 0.360 \\
& IBML & 0.045 & 0.023 & 0.511 & 0.231 & 0.021 & 0.091 & 0.199 & 0.128 & 0.643 \\
A. maoriana & Kau Bay & 0.027 & 0.008 & 0.296 & 0.240 & 0.007 & 0.029 & 0.111 & 0.033 & 0.297 \\
& IBML & 0.036 & 0.016 & 0.444 & 0.238 & 0.016 & 0.067 & 0.152 & 0.071 & 0.467 \\
M. galloprovincialis & Kau Bay & 0.026 & 0.010 & 0.385 & 0.242 & 0.007 & 0.029 & 0.107 & 0.041 & 0.383 \\
& IBML & 0.038 & 0.018 & 0.474 & 0.236 & 0.019 & 0.081 & 0.158 & 0.076 & 0.481 \\
\hline
\end{tabular}

\section{Statistical analysis $-P$. canaliculus}

ANOVA was performed to test for differences in RNA, DNA and RNA:DNA ratio between sites and days. RNA data were logged in order to satisfy assumptions of normality. An ANOVA tested the following model:

$$
\text { LogRNA }=\text { Constant }+ \text { Day }+ \text { Site }+ \text { Day } * \text { Site } .
$$

A step-wise ANOVA $(\alpha=0.15)$ identified Day as non-significant and removed it from the model. The remaining terms were retained in the model $\left(\mathrm{R}^{2}=0.286\right)$, although only site is significant at the 5\% level (Table 4.12), and RNA concentration was greater at IBML than at Kau Bay.

Table 4.12. Results from a reduced model ANOVA of RNA data for P. canaliculus.

\begin{tabular}{l|ccccc}
\hline & Sum of Squares & $\mathrm{df}$ & Mean Square & F-value & $\mathrm{p}$-value \\
\hline Site & 5.190 & 1 & 5.190 & 16.149 & $<0.001$ \\
Day*Site & 3.929 & 7 & 0.561 & 1.746 & 0.112 \\
Error & 22.820 & 71 & 0.321 & & \\
\hline
\end{tabular}


Data for the DNA analysis did not require transformation. An ANOVA was performed using the following model:

$$
\text { DNA }=\text { Constant }+ \text { Day }+ \text { Site }+ \text { Day } * \text { Site }
$$

The analysis identified all terms as having significantly different DNA concentrations; the $\mathrm{R}^{2}$ value for the model was 0.592 (Table 4.13). Although the interaction between Day and Site was significant, the overall mean DNA concentration was greater at Kau Bay than at IBML (Table 4.11).

Table 4.13. Results from an ANOVA of DNA data for P. canaliculus.

\begin{tabular}{l|ccccc}
\hline & Sum of Squares & df & Mean Square & F-value & p-value \\
\hline Site & 0.002 & 1 & 0.002 & 14.261 & $<0.001$ \\
Day & 0.008 & 7 & 0.001 & 7.932 & $<0.001$ \\
Day * Site & 0.003 & 7 & 0.000 & 3.310 & 0.005 \\
Error & 0.009 & 64 & 0.000 & & \\
\hline
\end{tabular}

An analysis of RNA:DNA ratio data required a log transformation. The analysis of the model $\left(\mathrm{R}^{2}=0.406\right)$ showed only site to be significant (Table 4.14). The ratio of RNA to DNA was greater at IBML than Kau Bay.

Table 4.14. Results from an ANOVA on RNA:DNA ratio data for $P$. canaliculus.

\begin{tabular}{l|ccccc}
\hline & Sum of Squares & df & Mean Square & F-value & p-value \\
\hline Site & 6.166 & 1 & 6.166 & 18.999 & $<0.001$ \\
Day & 3.969 & 7 & 0.567 & 1.747 & 0.144 \\
Day * Site & 4.089 & 7 & 0.584 & 1.800 & 0.103 \\
Error & 20.769 & 64 & 0.325 & & \\
\hline
\end{tabular}

\section{A. maoriana}

Transformations were not required in any of the analyses for A. maoriana. As with $P$. canaliculus a step-wise ANOVA was conducted to test for differences in RNA $\left(\mathrm{R}^{2}=0.460\right)$. This analysis showed all terms to be significant (Table 4.15). The same model was fitted to test for differences in DNA $\left(\mathrm{R}^{2}=0.760\right)$; this showed Day and the interaction term to be significant. Although Site is non-significant, it must be retained in the model due to the significant interaction term (Table 4.16). 
Table 4.15. Results from an ANOVA of RNA data for A. maoriana.

\begin{tabular}{l|ccccc}
\hline & Sum of Squares & df & Mean Square & F-value & p-value \\
\hline Site & 0.002 & 1 & 0.002 & 13.120 & 0.001 \\
Day & 0.002 & 7 & 0.000 & 2.213 & 0.045 \\
Day * Site & 0.003 & 7 & 0.000 & 3.539 & 0.003 \\
Error & 0.008 & 63 & 0.000 & & \\
\hline
\end{tabular}

Table 4.16. Results from an ANOVA of DNA data for A. maoriana.

\begin{tabular}{l|ccccc}
\hline & Sum of Squares & df & Mean Square & F-value & p-value \\
\hline Site & 0.000 & 1 & 0.000 & 2.707 & 0.105 \\
Day & 0.005 & 7 & 0.001 & 14.292 & $<0.001$ \\
Day * Site & 0.004 & 7 & 0.001 & 13.856 & $<0.001$ \\
Error & 0.003 & 63 & 0.000 & & \\
\hline
\end{tabular}

The ratio of RNA:DNA was also tested for differences between effects $\left(R^{2}=0.440\right)$. Table 4.17 shows that Site and the Site * Day interaction explained significant variation in RNA:DNA ratio. The ratio of RNA to DNA was greater at IBML than at Kau Bay.

Table 4.17. Results from an ANOVA of RNA:DNA ratio data for A. maoriana.

\begin{tabular}{l|ccccc}
\hline & Sum of Squares & df & Mean Square & F-value & p-value \\
\hline Site & 0.030 & 1 & 0.030 & 12.588 & 0.001 \\
Day & 0.030 & 7 & 0.004 & 1.803 & 0.102 \\
Day * Site & 0.057 & 7 & 0.008 & 3.425 & 0.004 \\
Error & 0.149 & 63 & 0.002 & & \\
\hline
\end{tabular}

\section{M. galloprovincialis}

A step-wise ANOVA on the raw data for differences in RNA concentration identified the Day * Site interaction as non-significant, and this was removed from the model. The remaining terms both explained significant variation in RNA concentration $\left(\mathrm{R}^{2}=0.342\right)$ (Table 4.18). RNA concentration was greater at IBML than Kau Bay.

Table 4.18. Results from an ANOVA of RNA data for M. galloprovincialis.

\begin{tabular}{l|ccccc}
\hline & Sum of Squares & df & Mean Square & F-value & p-value \\
\hline Site & 0.003 & 1 & 0.003 & 16.710 & $<0.001$ \\
Day & 0.004 & 7 & 0.001 & 2.943 & 0.009 \\
Error & 0.012 & 70 & 0.000 & & \\
\hline
\end{tabular}


In the analysis of DNA all terms were significant, $\mathrm{R}^{2}=0.742$. The concentration of DNA was greater at Kau Bay than IBML (Table 4.19).

Table 4.19. Results from a reduced model ANOVA of DNA data for M. galloprovincialis.

\begin{tabular}{l|ccccc}
\hline & Sum of Squares & df & Mean Square & F-value & p-value \\
\hline Site & 0.001 & 1 & 0.001 & 9.563 & 0.003 \\
Day & 0.0007 & 7 & 0.001 & 15.336 & $<0.001$ \\
Day * Site & 0.004 & 7 & 0.001 & 9.086 & $<0.001$ \\
Error & 0.004 & 63 & 0.000 & & \\
\hline
\end{tabular}

The ratio of RNA to DNA was tested for sources of variation, the model was fitted $\left(\mathrm{R}^{2}=0.472\right)$ and none of the terms were discarded. Only Site and Day however, are significant at the 5\% level (Table 4.20). The RNA:DNA ratio was greater at IBML than Kau Bay.

Table 4.20. Results from an ANOVA on the reduced model of RNA:DNA ratio data for $M$. galloprovincialis.

\begin{tabular}{l|ccccc}
\hline & Sum of Squares & df & Mean Square & F-value & p-value \\
\hline Site & 0.056 & 1 & 0.056 & 19.644 & $<0.001$ \\
Day & 0.070 & 7 & 0.010 & 3.506 & 0.003 \\
Day * Site & 0.033 & 7 & 0.005 & 1.648 & 0.139 \\
Error & 0.179 & 63 & 0.003 & & \\
\hline
\end{tabular}

ANOVA were also performed separately on each species at each site to determine whether there was a significant change in RNA, DNA and RNA:DNA over the $c .60 \mathrm{~d}$ period of the experiment. A summary of the results shows that at Kau Bay, none of the species showed any significant change in RNA, DNA or RNA:DNA over the study period; all p-values are very high (Table 4.21). At IBML, only RNA in $P$. canaliculus showed a significant difference over the course of the experiment, however the p-values in the other species were very much lower in all tests on IBML mussels (Table 4.21).

Table 4.21. P-values from ANOVA to test for differences between data recorded at Day one and those from Day 60 for each species at each site.

\begin{tabular}{l|cccc}
\hline & Site & RNA & DNA & RNA:DNA \\
\hline \multirow{2}{*}{ P. canaliculus } & Kau Bay & 0.966 & 0.676 & 0.933 \\
& Island Bay & 0.045 & 0.384 & 0.088 \\
\cline { 2 - 5 } A. maoriana & Kau Bay & 0.889 & 0.767 & 0.888 \\
\multirow{4}{*}{ M. galloprovincialis } & Island Bay & 0.106 & 0.169 & 0.077 \\
\cline { 2 - 5 } & Kau Bay & 0.956 & 0.423 & 0.954 \\
& Island Bay & 0.166 & 0.164 & 0.133 \\
\hline
\end{tabular}


The shell length of animals used in this experiment was deliberately kept to a narrow range. ANOVA showed differences in shell length between sites for A. maoriana and M. galloprovincialis, and whilst these differences were significant, the range of mussels used in the experiment is small (Table. 4.22).

Table 4.22. Size of mussels (mean $\pm S D$ ) used in RNA:DNA experiment and results of ANOVA testing for differences in shell length between sites for each species.

\begin{tabular}{|c|c|c|c|c|}
\hline & Site & Mean shell length ( \pm SD) & F-value & p-value \\
\hline P. canaliculus & $\begin{array}{c}\text { Kau Bay } \\
\text { Island Bay }\end{array}$ & $\begin{array}{c}90.31(11.28) \\
87.78(7.14)\end{array}$ & 1.490 & 0.226 \\
\hline A. maoriana & $\begin{array}{l}\text { Kau Bay } \\
\text { Island Bay }\end{array}$ & $\begin{array}{l}56.38(5.52) \\
58.90(3.87) \\
\end{array}$ & 5.811 & 0.018 \\
\hline M. galloprovincialis & $\begin{array}{l}\text { Kau Bay } \\
\text { Island Bay }\end{array}$ & $\begin{array}{l}60.20(4.23) \\
57.89(5.08)\end{array}$ & 5.117 & 0.026 \\
\hline
\end{tabular}

\subsection{Discussion}

The condition of mussels held at IBML and fed on ambient Cook Strait water decreased over time compared to mussels within the Harbour. Although the conditions in which mussels were kept differs between sites, mussels at IBML were not exposed to predation, tidal emersion, wave action or other potentially stressful conditions. An intuitive association between ration quality and condition has been documented by Thompson and Bayne (1974) who demonstrated that flesh weight and metabolic rate were affected by ration in Mytilus edulis. A number of other workers have also shown a relationship between a decrease in condition and low food quality (Rosenberg \& Loo, 1983; Chaparro \& Winter, 1983). Ceccherelli and Barboni (1983) showed condition to increase with food availability and decrease with increased levels of inorganic detritus in M. galloprovincialis. More recently, Hickman et al. (1991) found for $P$. canaliculus at low ambient food levels, that condition index was strongly associated with changes in food concentration. The decline in condition of mussels held at IBML is likely to be a result of lower seston quality observed at Coastal sites as reported in Chapter Two. James et al. (2001) suggested that chlorophyll $a$ concentrations of 0.2-0.3 $\mu \mathrm{g} \mathrm{l^{-1 }}$ are close to the lower threshold at which carbon uptake would not meet metabolic demands in P. canaliculus. Such low levels of chlorophyll $a$ were present at most Coastal sites all year round $\left(0.07-0.25 \mu \mathrm{g} \mathrm{l}^{-1}\right)$. In contrast, chlorophyll $a$ at Harbour sites was above this threshold for most of the year (Chapter Two, Fig. 2.8). Hickman et al. (1991) found evidence of differences in mussel body 
condition among three regions of Pelorus-Kenepuru Sound. The Inner Sound mussels generally had the highest condition, middle sites showed medium condition and outer sites the lowest condition. This decrease in condition correlated with a decrease in food concentration, (chlorophyll $a$, TPM and particulate carbon) between the Inner and Outer Sounds. This is analogous with the situation on the South Coast. Terrestrial run-off and a longer residence time of $\approx 10 \mathrm{~d}$ (Heath, 1977) act to enrich Harbour water, while Coastal water is derived from oligotrophic Cook Strait water. These same Cook Strait currents also supply the outer regions of Pelorus Sound. Mussels are also absent from these Outer Sounds and long stretches of coastline along southern Cook Strait (e.g. Stephens Island) (Gardner, pers. comm.; pers. obs.).

Condition in the Harbour population of $P$. canaliculus was very similar to that reported by Hickman and Illingworth (1980) and Anderlini (1989). At Mahanga Bay, Wellington, Hickman and Illingworth reported a mean condition index over the year for P. canaliculus of 13.9 ( \pm 0.26$)$. Anderlini (1989) reported mean condition of 14.16 for $P$. canaliculus at seven sites around Pencarrow Head. These data compare well to P. canaliculus in this study where a means of $14.25( \pm 1.81)$ and $12.85( \pm 3.35)$ were recorded from Harbour and IBML mussels respectively. The condition index of $M$. edulis aoteanus (M. galloprovincialis) was also recorded by Anderlini (1989) who reported a mean of 11.71 . In my study, $M$. galloprovincialis had a mean condition index of $14.8( \pm 2.4)$ for mussels from the Harbour and $13.33( \pm 2.47)$ for those held at IBML. Comparisons with the work of Anderlini (1989) are complicated by the fact that the sites used were across the boundary of what are considered Harbour and Coastal in this study.

Hickman et al. (1991) found the condition index of $P$. canaliculus in PelorusKenepuru Sound varied markedly among stations, months, and years. Condition was generally high at the beginning of spring and decreased over spring to a low in summer, presumably as spawning occurred. This same general trend was observed in condition over the first year in this study, however the pattern is not repeated during the same period the next year. Hickman et al. (1991) also reported that overall condition was significantly lower $(\mathrm{p}<0.001)$ in the second year of their study and the trend of condition decrease during the spring was not as apparent as in the first year. Hickman et al. (1991) concluded that variations in condition were most likely due to 
localised environmental conditions and therefore emphasised the importance of sitespecific factors in determining mussel condition.

Seston and condition in Harbour mussels proved to be un-correlated in this study. Mussel growth has been linked to chlorophyll $a$ in Mytilus edulis (Page \& Hubbard, 1987). They found that a 2-4 wk lag existed between chlorophyll $a$ concentrations and length-specific growth rate. These changes were also related to mussel size; smaller mussels (20-35 mm) experienced a shorter time lag (2 wk) compared to larger mussels (35+ mm, 4 wk) (Page \& Hubbard, 1987). When correlations between chlorophyll $a$ and condition were offset by one month time lags, correlations were found to be strongest when no time lag existed.

While no measure of mortality was taken at Harbour sites, it is unlikely that such high mortality ( $\approx 60 \%$ in $P$. canaliculus and $M$. galloprovincialis) existed in Harbour mussels. Cheung (1993) observed a mass mortality (>95\%) of Perna viridis in the inner Tolo Harbour, Hong Kong. This Harbour is known to be polluted and mussels are subject to additional stress from high water temperatures $\left(16-32^{\circ} \mathrm{C}\right)$, low dissolved oxygen (annual mean $5.52 \mathrm{mg} \mathrm{l}^{-1}$ ), red tide events and exposure to air at midday (Cheung, 1993). Wellington Harbour is not considered polluted, has lower water temperatures $\left(10-20^{\circ} \mathrm{C}\right)$ and higher dissolved oxygen levels (7-8 $\left.\mathrm{mg} \mathrm{l}^{-1}\right)$ (pers. obs.). Other authors have suggested that high mortality is the result of a combination of factors. Tremblay et al. (1998) suggested high summer mortality in Mytilus edulis was the result of an interaction between high summer temperatures $\left(>20^{\circ} \mathrm{C}\right)$, dietary deficiency and post-spawning stress. Incze et al. (1980) found a similar interaction between mortality, water temperature and decrease in available diet in Mytilus edulis, and suggested a further interaction with the metabolic demands associated with gametogenesis. Bayne et al., (1982) observed that Mytilus edulis used a large proportion of energy reserves during gametogenesis, and hence mussels were less able to withstand environmental stress for prolonged periods, thus increasing the risk of mortality (Bayne et al., 1978; Incze et al., 1980; Worrall \& Widdows, 1984; Emmett et al., 1987). Mussels at IBML were not exposed to pollutants, high water temperatures or low dissolved oxygen levels, nor was any spawning activity observed. Therefore, it seems likely that mortality is primarily the result of poor food quality. With the exception of energy utilisation due to gametogenesis, mussels in Wellington 
Harbour do not experience these stresses either. This would suggest lower levels of mortality than those seen at IBML.

Gonad masses in these experiments do not show the same decrease as seen with condition index in IBML mussels. The coefficient of variation over the sampling period was higher at IBML in all species compared to mussels from Harbour sites. This high variability is likely to be due to the varying capacity and timing of individuals compensating for stress caused by low food quality. Gonad mass can decline for one of two reasons: spawning, or resorption of gonad due to unfavourable environmental conditions (Bayne \& Newell, 1983; Emmett et al., 1987). It is most likely that gonad decrease in mussels from Harbour populations was due to spawning given that this is a natural population and environmental conditions appear to be more suitable. Mussels held at IBML however may have experienced gonad mass reduction due to resorption. It is difficult to establish that resorption occurred as opposed to spawning, but given the high degree of mortality in IBML mussels, resorption seems the more likely scenario. During the experiment mussels held at IBML were checked almost daily to ensure the water supply was adequate. Although stress is known to induce spawning, at no time were any gametes observed on the bottom of the aquaria. Gardner (pers. comm.) observed mussel gametes as a thick conspicuous film on the bottom of tanks in experiments at IBML, while I have also observed mussels spawning in other experiments.

Kennedy (1977) observed a decline in the gonad index of A. maoriana and Mytilus edulis aoteanus (=galloprovincialis) in August to an 'inactive' period from late December to early February when $40-50 \%$ of individuals were spent or resting. The timing of the present study makes the comparison between Harbour and IBML mussels difficult due to the fact that it was conducted over the period when natural spawning occurs. Had the experiment been run during the autumn and winter after mussel spawning and subsequent gonad development, any gonad resorption by IBML mussels may have been more easily detected. While statistical data point toward differences in gonad mass between sites in $P$. canaliculus and possibly $M$. galloprovincialis, I am inclined to treat these data with extreme caution. This is due to the counter-intuitive nature of the results is some cases, particularly in P. canaliculus, 
and the manner in which results dramatically changed with the removal of four outliers in the case of M. galloprovincialis.

Studies to test the validity of the RNA:DNA method under controlled laboratory conditions using starved or artificially conditioned animals have proved successful (Wright \& Hetzel, 1985; Chícharo \& Chícharo, 1995; Paon \& Kenchington, 1995), however few studies have been conducted in the field (Robbins et al., 1990; Lodeiros et al., 1996; Kenchington, 1994). Results from the analysis of RNA:DNA ratio showed a significant difference in all three species held at IBML compared with those from Kau Bay. However, the analysis of RNA:DNA assumes that DNA concentrations remain constant throughout the experiment, and as such, no differences should be observed between sites. Any decrease in RNA:DNA ratio would therefore be a result of declining RNA concentration. This assumption did not always hold true, and as such, may cast doubt on the validity of some of the results. DNA concentration in P. canaliculus and M. galloprovincialis showed significant differences between sites. Despite this, these data provide a valuable corroboration of the somatic condition index and provide further evidence that a nutritional deficiency in Cook Strait water is causing mussels to lose condition by resorption of body tissues. Further tests showed that there were some differences between sites when comparing each species' RNA, DNA and RNA:DNA ratio within each site over the duration of the experiment. Although only one of the 18 tests showed a significant difference, the overall trend showed strongly non-significant results for Kau Bay and borderline significant results for Island Bay (Table 4.21). Another anomalous result of this experiment was the generally higher RNA:DNA ratio and concentration of RNA in mussels held at IBML compared to Kau Bay (Table 4.11). This occurred in all three species and no logical explanation has yet been attributed to this finding.

It has been shown that the ratio of RNA:DNA varies with size to differing extents within different bivalves. Kenchington (1994) reported that small size class scallops Placopecten magellanicus, had a significantly higher RNA:DNA ratio than two larger size classes. Lodeiros et al. (1996) cite an example from Mayrand et al. (1994) which shows no correlation between RNA:DNA ratio and size in Mya arenaria. Lodeiros et al. (1996) reported a decrease in RNA:DNA ratio in Euvola ziczac with increased size. Nuscetti and Morales (1988, fide. Lodeiros et al., 1996) reported a contrasting 
relationship in the mussel Perna perna, which showed an increase in RNA:DNA ratio from small to intermediate sizes and then a decrease for larger mussels. In this study, shell length was significantly different between sites for A. maoriana and $M$. galloprovincialis, but this is primarily due to the low within-site variation in shell length (Table 4.22). However, given that mean shell length between sites did not differ by more than $3 \mathrm{~mm}$ for any species, it would be difficult to argue that mussels at different life history stages were being used, and were therefore biasing the analysis.

In summary, both somatic condition and RNA:DNA ratio decreased in mussels held at IBML compared to those from the Harbour. Given the well established link between seston quality and condition, this reduction in condition is likely to be caused by food limitation. Gonad mass does not show the same clear decrease in the IBML population compared to Harbour mussels, however this may be complicated by spawning activity. Gonad data also displayed large variations between months, and results of statistical tests were counter-intuitive at times. The ratio of RNA to DNA corroborated the somatic condition indices in that it was seen to decrease in mussels held at IBML compared to those within the Harbour. In addition, in each species, decreases in RNA during the experiment were greater in mussels held at IBML than from the Harbour. Observations of condition index (Table 4.1), gonad mass (Table 4.6), RNA, DNA and RNA:DNA (Table 4.11) showed an increase in variability in mussels at IBML when compared to Harbour mussels. This may be due to different magnitude and timing of compensatory mechanisms due to stress. However, in some cases the increased variation in animals held at IBML may be due to the overall decrease in condition or gonad mass of animals held at IBML and therefore an increased overall variation. 


\section{CHAPTER FIVE}

\section{Feeding Physiology}

\subsection{Introduction}

For any organism to survive it must consume enough food to maintain routine metabolic functions, thus if an animal is not able to procure sufficient food, it will utilise its reserves and ultimately die. The energy budget of a bivalve is a combination of basic physiological functions such as feeding rate, respiration rate, absorption of food, excretion of waste products and production. The amount of energy available for somatic and reproductive growth can be determined using the following equation (Widdows \& Donkin, 1992):

$$
C=P+R+E+F
$$

where $\mathrm{C}=$ total consumption of food, $\mathrm{P}=$ total production (shell, somatic tissue and gametes), $\mathrm{R}$ = respiratory expenditure (costs of maintenance, feeding, digestion and growth), $\mathrm{E}=$ energy lost as excreta and $\mathrm{F}=$ faecal energy loss.

In mussels it is possible to measure individually each component of the energy budget to determine the net energy available for somatic and reproductive growth; this is known as scope for growth (SFG). Clearance rate (CR), absorption efficiency (AE) and seston characteristics are the components of the energy budget that determine energy input. CR is the volume of water cleared of particles over a given time. When this is multiplied by the organic content per unit volume of the seawater, the gross potential energy available to the organism can be calculated. Mussels have the ability to sort food on the gill and labial palps after it has been filtered (Bayne \& Hawkins, 1990) and in times when pre-ingestive selection is occurring they may void some of the filtered ration as pseudofaeces bound in mucous. Thus the ingested ration is the filtered ration less any pseudofaecal material which is produced. This however does not represent the net energetic input into the organism. There are losses that result from endogenous substances that are rejected. Collective egesta such as epithelial cells, enzymes and other substances that are secreted into the gut but not reabsorbed 
are termed metabolic faecal loss (MFL) (Hawkins \& Bayne, 1992). MFL represents the ongoing costs of intra and extra-cellular digestion and can be substantial even when ration is adequate (Bayne \& Hawkins, 1990). The measurement of net absorption efficiency (AE) takes this loss into account but does not quantify the MFL (Hawkins \& Bayne, 1992). The net AE is the proportion of ingested material gained by the organism after all losses related to the digestion and assimilation of the ration have been taken into account, this may be positive or negative depending on the degree of MFL. Gross absorption efficiency does not take into account material that is secreted or abraded into the gut and the difference between gross and net $\mathrm{AE}$ is the MFL (Bayne \& Hawkins, 1990; Hawkins \& Bayne, 1992).

While working at low mean TPM and POM values of $3.8 \mathrm{mg} \mathrm{l}^{-1}$ and $0.9 \mathrm{mg} \mathrm{l}^{-1}$ respectively, Gardner and Thompson (2001) reported no pseudofaecal deposition for P. canaliculus at Island Bay, Wellington. Hawkins et al. (1999) found that pseudofaecal material was deposited by $P$. canaliculus in all but very low seston concentrations (c. 2-5 mg TPM l $\mathrm{m}^{-1}$ ). This challenges the view that pseudofaecal deposition is a reaction to TPM levels that are greater than can be accommodated. Hawkins et al. (1999) suggest that such studies are based on diets of algal monoculture and therefore mussels are not able to utilise their ability to select for preferred particles and cannot produce pseudofaecal material. As a consequence, no sorting occurs and the possibility for enrichment of ingested ration is not available.

In addition to energy utilisation by way of endogenous losses as mentioned above, energetic losses also occur due to metabolism. "Determination of the total rate of heat dissipation from living organisms by means of calorimetry is a non-specific measure of total metabolic activity and all direct costs” (Hawkins \& Bayne, 1992, p. 177). This is generally done indirectly by measuring oxygen uptake and using oxycalorific equivalents to estimate heat loss and hence metabolic activity (Hawkins \& Bayne, 1992).

Oxygen consumption is related in complex ways to numerous endogenous and exogenous factors, some of which are outlined below. Many workers have found that oxygen consumption is directly related to food concentration. Thompson and Bayne (1972) observed an increase in oxygen consumption in Mytilus edulis related to suspended particle concentration. Other published data support this relationship in 
Mytilus edulis (Thompson, 1984; Bayne et al., 1987), Aulacomya ater (Griffiths \& King, 1979; van Erkom Schurink \& Griffiths, 1992), Perna perna (van Erkom Schurink \& Griffiths, 1992), M. galloprovincialis (van Erkom Schurink \& Griffiths, 1992), Choromytilus meridionalis (van Erkom Schurink \& Griffiths, 1992) and $P$. canaliculus (James et al., 2001). An increase in water temperature has also been related to an increase in oxygen consumption. This has been observed in $P$. canaliculus (Marsden \& Weatherhead, 1998), Aulacomya ater (van Erkom Schurink \& Griffiths, 1992), Perna perna (van Erkom Schurink \& Griffiths, 1992), M. galloprovincialis (van Erkom Schurink \& Griffiths, 1992) and Choromytilus meridionalis (van Erkom Schurink \& Griffiths, 1992). However, James et al. (2001) reported no such relationship in studies of $P$. canaliculus.

Other influences on oxygen consumption include body size (Griffiths \& King, 1979; Stuart, 1982; Gardner \& Thompson, 2001; James et al., 2001) and reproductive condition. Bayne (1973) found that during active gametogenesis, when energy reserves are high, mussels utilise these reserves and thus keep oxygen demand high. When these reserves are depleted after the completion of gametogenesis and vitellogenesis, starvation may result and oxygen consumption will decrease. Thompson (1984) found high levels of oxygen consumption at low winter temperatures in Mytilus edulis and attributed this to gametogenic activity. He goes on to say however, that this relationship is not evident consistently at all sites throughout the study.

Another form of energy loss is the excretion of waste products. This is measured as ammonia excretion and although not quantified in this study, previous studies have shown this to be a small component of the energy budget. For example, studies of $M$. edulis by Okumu and Sterling (1994) show ammonia excretion to utilise only $\approx 2-3 \%$ of the energy accounted for by respiration.

A large body of work exists that reports SFG and each of the components of energy budgets for mussels. Most work focuses on either using SFG as an environmental indicator of stress (Widdows \& Johnson, 1988; Navarro et al., 1991; Cheung, 1993; Okumu • \& Sterling, 1994; Gardner, 2000) or the response of feeding behaviours to different seston conditions (Bayne, 1973; Berry \& Schleyer, 1983; Hawkins \& Bayne, 
1984; Bayne et al., 1987; Bayne et al., 1988; Hawkins et al., 1990; Navarro et al., 1992; Hawkins et al., 1996; Hawkins et al., 1999; Wong \& Cheung, 1999; Gardner, 2001). Many of these papers observed feeding responses to differing diet concentrations using artificial algal monocultures, some with the addition of inorganic silt. However, it has been noted recently that bivalves feeding on natural seston show very different responses to those fed on algal monocultures (Navarro et al., 1992; Hawkins et al., 1996; Hawkins et al., 1999). It was noted by Hawkins et al. (1996) that only models of feeding behaviour derived from bivalves feeding on natural seston were in good agreement with experimental observations. This difference in diet composition (natural vs. laboratory monocultures) led to some contradictory results of feeding experiments. A decline in CR had been observed when animals were fed with increasing concentrations of pure algal diets (Davids, 1964; Winter, 1973; FosterSmith, 1975, fide. Hawkins et al., 1996) or pure inorganic material (Cranford \& Gordon, 1992). One explanation for this is the traditional view that high concentrations of inorganic material smother mussel gills and dilute organic ingestion concentrations (Jørgensen, 1966; Widdows et al., 1979; fide. Hawkins et al., 1996). This explanation is somewhat controversial and thought by many to be incorrect at all but extreme seston concentrations (Hawkins et al., 1996; Hawkins et al., 1999). In contrast, Hawkins et al. (1996) cite examples of increased feeding and absorption rates with increasing TPM (Winter, 1976; Griffiths, 1980; Kiørboe et al., 1980 and 1981, fide. Hawkins et al., 1996).

In a comprehensive study of the feeding behaviour of $P$. canaliculus, Hawkins et al. (1999) have shown that filtration rate increases with increasing TPM to very high concentrations (1000 $\mathrm{mg} \mathrm{l}^{-1}$ ) before declining due to over-loading of the gill. As TPM increases it is generally accepted that the fraction of organic material decreases (Widdows et al., 1979; Navarro et al., 1991; Hawkins et al., 1996). Hawkins et al. (1999) have shown that despite the increase in the inorganic fraction of filtered seston, selective processes act to concentrate organic material prior to ingestion to levels higher than those of the natural seston, the unwanted material being voided as pseudofaeces. This concentration of ingested material also has the effect of increasing the efficiency with which organic material is absorbed from ingested material (Hawkins et al., 1999). Therefore as the organic content of ingested material increases with increasing TPM, the net organic absorption rate also increases. As the proportion 
of organic material in the seston decreases with increasing TPM, in order to ensure enrichment of ingested material, the proportion of filtered particles rejected as pseudofaeces must also increase with increasing TPM. These responses to differing seston conditions ensure that mussels can alter their feeding behaviour to compensate for daily changes in seston caused by tides, meteorological events and seasonal changes. However, this further complicates these findings. For example, studies may show a relationship between clearance rate and TPM, when the animal is in fact responding to chlorophyll $a$. If studies are observing feeding behaviour outside the critical range of an important variable, results may be interpreted incorrectly. This will be examined further later in this chapter. Gardner (2001) examined the feeding response of (P. canaliculus, A. maoriana and M. galloprovincialis) over a wide range of natural seston, and found that each species altered its feeding behaviour in response to different seston characteristics.

It is hypothesised that animals being held at IBML and feeding on ambient Cook Strait water are experiencing a net energy loss due to poor food supply (Gardner \& Thompson, 2001). This would corroborate the results of the condition index study (Chapter Four) and support the contention that poor water quality is a major factor limiting mussel distribution along the South Coast. In this study animals were taken from the Harbour, and after acclimation, their oxygen consumption rates were measured to determine energy output. Mussels were fed on ambient Cook Strait water to determine CR and AE. From these data SFG values were estimated to ascertain the suitability of Cook Strait water for mussel survivorship. Water sampling has shown that the seston characteristics at Island Bay show less seasonal variation compared to Harbour sites, especially in organic content and percent organic content (Chapter Two; Gardner, 2000). For this reason these experiments were conducted over a very narrow range of seston concentrations compared to other studies, particularly those investigating plasticity of feeding behaviour under different environmental conditions (e.g. Hawkins et al., 1996; Hawkins et al., 1999; Gardner, 2001). As such, detailed investigations of feeding responses due to varying seston conditions are outside the scope of this chapter. 


\subsection{Materials and Methods}

\section{Mussel collection and holding conditions}

Mussels were collected consistently at low tide from Seatoun, Wellington Harbour and transported to IBML where they were acclimatised to ambient conditions for 7-10 days (Hawkins et al., 1996; Gardner, 2000). Mussels of all three species were collected over as large a size range as possible. All epibioants were cleaned from mussels before storage in glass aquaria $(l \times w \times d, 590 \times 300 \times 230 \mathrm{~mm})$ that were supplied with ambient Cook Strait water. Care was taken not to limit access to food by over-stocking aquaria; stocking density was approximately similar to natural densities.

\section{Oxygen consumption Rates $\left(\mathrm{VO}_{2}\right)$}

Individuals of each species were sealed in a watertight perspex container filled with seawater (c. $400 \mathrm{ml}$, for larger mussels a c. $1700 \mathrm{ml}$ container was used). A YSI 55 oxygen probe was inserted into the lid of the container. The mussel was placed on a stand in the bottom of the container so a stirring bar could spin beneath the animal and allow water mixing inside the container in order to obtain accurate readings of the water oxygen content. The container was placed in a water bath to ensure the temperature $\left( \pm 0.1^{\circ} \mathrm{C}\right)$ would remain constant and the water bath was elevated to allow a magnetic stirrer to be placed beneath it. When each mussel began to feed, the oxygen content and time were noted and checked several times over a 30-60 min period in order to ensure the animal was still respiring. At the end of each experiment the mussels were shucked and dried at $60^{\circ} \mathrm{C}$ for $24-48 \mathrm{~h}$.

Oxygen consumption rates are influenced to some degree by water temperature (see introduction). This experiment was therefore conducted at two different times of the year. The first round of experiments ('low temperature') was conducted in May 1998 at a temperature of approximately $14^{\circ} \mathrm{C}\left( \pm 0.5^{\circ} \mathrm{C}\right)$. Fifteen individuals of each species in a broad range of sizes were used for these experiments; the range of dry tissue weights for each species was as follows: P. canaliculus, 0.60-3.52 g; A. maoriana, 0.27-2.63 g; M. galloprovincialis, 0.39-3.17 g. The second round of experiments ('high temperature') was conducted in February 2000 at temperatures of $16.5-17.0^{\circ} \mathrm{C}$ $\left( \pm 0.5^{\circ} \mathrm{C}\right)$. Six individuals of each species were used with a range of tissue dry weight for each species was as follows: P. canaliculus, 0.41-2.1 g; A. maoriana, 0.45-1.09 g; 
M. galloprovincialis, $0.30-0.58 \mathrm{~g}$. While the range of temperatures is relatively narrow, it represents approximately half of the temperature range of the extremes recorded at IBML in Chapter Two (Figure 2.2 \& Appendix A1).

All oxygen consumption rates were corrected to a standard dry weight of one gram to compensate for mass related bias, and to allow comparison among species, using the following equation:

$$
\mathrm{Y}_{\mathrm{s}}=\left(\mathrm{W}_{\mathrm{s}} / \mathrm{W}_{\mathrm{e}}\right)^{\mathrm{b}} \mathrm{Y}_{\mathrm{e}}
$$

where; $\mathrm{Y}_{\mathrm{s}}$ is the oxygen consumption rate of the standard animal, $\mathrm{W}_{\mathrm{s}}$ is the standard weight $(1 \mathrm{~g}), \mathrm{W}_{\mathrm{e}}$ is the weight of the experimental animal, $b$ is the power function for oxygen consumption rate (gradient of $\log \mathrm{VO}_{2}$ vs $\log$ dry weight plot) and $\mathrm{Y}_{\mathrm{e}}$ is the uncorrected oxygen consumption rate. These data were converted into energetic equivalents where $\mathrm{R}=\mathrm{VO}_{2}\left(\mathrm{ml} \mathrm{O}_{2} \mathrm{~g}^{-1} \mathrm{~h}^{-1}\right) * 20.33 \mathrm{~J} \mathrm{ml}^{-1} \mathrm{O}_{2}$ (Widdows \& Johnson, 1988) to enable integration into scope for growth calculations. These data were intended solely for use in SFG calculations, and as such, no among-species statistical analyses are conducted.

It has been noted (Bayne, 1973; Bayne \& Newell, 1983) that mussels experiencing periods of low food availability can reduce their respiratory effort in order to conserve energy. It was hypothesised that mussels fed on ambient Coastal water were in fact being starved. Therefore, the oxygen consumption rates of mussels held at IBML for $10 \mathrm{wk}$ were measured to see if they displayed depressed oxygen consumption rates compared to those from the initial experiment, which may be indicative of animals under long-term stress. This experiment was conducted in September 1998 using the same protocols at a temperature of approximately $12.5^{\circ} \mathrm{C}\left( \pm 0.5^{\circ} \mathrm{C}\right)$. Data were collected for varying sized mussels, the number of individuals and dry tissue weight range is as follows: six individuals of $P$. canaliculus $(0.14-1.68 \mathrm{~g})$ and $M$. galloprovincialis (0.48-1.78 g) and 10 of A. maoriana (0.25-0.58 g).

\section{Seston analysis}

Samples to determine TPM, POM and PCOM were filtered on to a $47 \mathrm{~mm}$ pre-ashed, pre-weighed Whatman GF/C filter and dried at $60^{\circ} \mathrm{C}$ for $24 \mathrm{~h}$. Filters were then weighed again to determine their dry weight or total particulate matter (TPM), and 
ashed at $450^{\circ} \mathrm{C}$ for $\approx 24 \mathrm{~h}$. Filters were then weighed a final time to determine the ash weight. The particulate organic matter (POM) is then calculated as TPM-ash weight. Percent organic matter (PCOM) is the percentage of TPM that is organic, and is calculated as (POM / TPM)*100. All filters were weighed on an Ainsworth ACA 100 KS balance to an accuracy of $0.0001 \mathrm{~g}$.

Water samples to determine chlorophyll $a$ concentration were filtered on to $47 \mathrm{~mm}$ Whatman GF/C filters and wrapped in aluminium foil for storage at $-20^{\circ} \mathrm{C}$ until determination of chlorophyll $a$ concentration. Samples were not left in storage for more than three weeks as recommended by Arar and Collins (1992). To determine chlorophyll $a$, each filter was put into a cuvette, $5 \mathrm{ml}$ of 90\% HPLC grade acetone were added and the top was covered with parafilm to prevent evaporation. Samples were refrigerated overnight to allow extraction and measured the following day using a Turner Designs AU-10 fluorometer. After the initial reading in the fluorometer three drops of $0.1 \mathrm{M} \mathrm{HCl}$ were added to each sample to acidify phaeopigments and a second measurement was made one minute later. Chlorophyll $a$ concentration is the difference between the two measurements after adjustments for cuvette volume are made.

Particle counts were made using a Z1 Coulter Counter. Counts were made of $1.0 \mathrm{ml}$ of seawater in two size classes, 2.5-5.0 $\mu \mathrm{m}$ and 5.0-63.0 $\mu \mathrm{m}$.

During the first A. maoriana experiment in June 1998, a southerly storm event occurred. It was decided to leave all mussels in the experimental apparatus for several days to observe the response of $\mathrm{CR}_{\mathrm{s}}, \mathrm{AE}$ and SFG to this natural pulse in seston. In subsequent analyses, some data are presented twice (i.e. including and excluding the southerly storm event).

\section{Clearance Rate}

These experiments were carried out on five occasions as follows: June 1998, March 1999, June 1999, February 2000 and September 2000. On each of these occasions, the CR of 24 mussels of each species was determined. The range of dry tissue weights for each species was as follows: P. canaliculus, 0.22-5.63 g; A. maoriana, 0.20-2.04 g; M. galloprovincialis, 0.20-3.39 g. The CR of each species was calculated using 
differential particle counts in a flow through system (Bayne et al., 1976; Gardner, 2000). Ambient Cook Strait water was pumped into a header tank (20 l) with an outflow at the top to maintain a constant water pressure. The inflow water was passed through a $250 \mu \mathrm{m}$ sieve in order to extract debris that may block water flow into each experimental chamber. At the bottom of the header tank were 13 small holes that fed into individual PVC tubes, each of which led to an individual container (500 ml). In each container the water flowed into the bottom and out through a tube at the top of the container on the opposite side. Mussels were placed into 12 of the 13 containers and allowed to feed; one container was left empty as a control. Three times a day a water sample was collected from the outflow tube of each chamber and the number of particles was counted using a Z1 Coulter Counter fitted with a $100 \mu \mathrm{m}$ aperture that counted particles in the range 2.5-63.0 $\mu \mathrm{m}$. The volume of each sample counted was 1 ml. A sample was also counted from a control container to compare with each experimental container. The flow rate into each container was measured via the outflow tube, and was maintained at a constant rate between $100-200 \mathrm{ml} \mathrm{min}^{-1}$ depending on the size of the mussel. At the end of each day all mussels were shucked and dried at $60^{\circ} \mathrm{C}$ for $24-48 \mathrm{~h}$. CR was calculated using the following equation:

$$
\mathrm{CR}\left(\mathrm{l} \mathrm{h}^{-1}\right)=((\text { Control Count }- \text { Experimental Count }) / \text { Control Count }) * \text { Flow Rate }
$$

As with oxygen consumption rate, a broad size range of mussels was used and all clearance rates were standardised to $1 \mathrm{~g}$ dry tissue weight to compensate for mass related bias. The procedure used was the same as that for the standardisation of oxygen consumption rates. The regression analyses from which the b-values were calculated are as follows:

P. canaliculus, $\mathrm{Y}=0.163(\mathrm{x})+0.446, \mathrm{n}=323, \mathrm{R}^{2}=1.2$

A. maoriana, $\mathrm{Y}=0.211(\mathrm{x})+0.159, \mathrm{n}=348, \mathrm{R}^{2}=1.6$

M. galloprovincialis, $\mathrm{Y}=0.107(\mathrm{x})+0.156, \mathrm{n}=194, \mathrm{R}^{2}=0.75$

Standardised clearance rate is referred to as $\left(\mathrm{CR}_{\mathrm{s}}\right)$.

\section{Absorption Efficiency (AE)}

These experiments were carried out on five occasions as follows: June 1998, March 1999, June 1999, February 2000 and September 2000. On each of these occasions, the AE of 24 mussels of each species was determined. At three times during the day $3 \times 2$ 
l water samples were taken from the header tank in order to obtain TPM, POM and PCOM. At the end of each day the faecal material present in each experimental container was carefully removed using a pipette and filtered onto a pre-ashed, preweighed Whatman GF/C filter. Any pseudofaecal material present was pipetted onto a separate pre-ashed, pre-weighed Whatman GF/C filter. Pseudofaecal material was easily distinguished from faeces by appearance; pseudofaeces appeared as a diffuse pile compared to the more uniformly shapes faecal pellets. The time of collection was also noted to allow the rate of pseudofaecal production to be calculated. Filters were then dried at $60^{\circ} \mathrm{C}$ for $24 \mathrm{~h}$, re-weighed, ashed at $450^{\circ} \mathrm{C}$ for $24 \mathrm{~h}$ and weighed again in order to obtain the total mass of pseudofaecal material and proportion of organic material present in each sample. AE was calculated using Conover's ratio (Conover, 1966) as follows:

$$
\mathrm{AE}=(\mathrm{F}-\mathrm{E}) /((1-\mathrm{E}) \mathrm{F})
$$

where $\mathrm{F}=\mathrm{AFDW}$ to dry weight ratio of seston

$\mathrm{E}=$ AFDW to dry weight ratio of faeces.

\section{Scope for Growth (SFG)}

SFG was calculated according to Widdows and Johnson (1988). However, ammonia excretion was not included and, as a result SFG will be slightly over-estimated. POM was converted to an energy equivalent $(1 \mathrm{mg}=23 \mathrm{~J})$ according to Widdows and Johnson (1988). Where pseudofaeces (PSF) were produced, it was necessary to correct for their presence because cleared ration is not equal to ingested ration as some of the cleared ration is voided. Production $(\mathrm{P})$ is therefore expressed by the equation as follows:

$$
\mathrm{P}=(\mathrm{C} * \mathrm{AE})-\mathrm{R}
$$

where $\mathrm{C}=\left(\left(\mathrm{CR}\left(\mathrm{l} \mathrm{g}^{-1} \mathrm{~h}^{-1}\right) *\right.\right.$ POM $\left.\left.\left(\mathrm{mg} \mathrm{l}^{-1}\right)\right)-\mathrm{PSF}\left(\mathrm{POM} \mathrm{mg} \mathrm{h}{ }^{-1}\right)\right) * 23 \mathrm{~J} \mathrm{mg}^{-1} \mathrm{POM}$

$$
\text { PSF }=\text { Pseudofaeces }
$$

$\mathrm{AE}=$ Absorption efficiency

$\mathrm{R}=\mathrm{VO}_{2}\left(\mathrm{ml} \mathrm{O}_{2} \mathrm{~g}^{-1} \mathrm{~h}^{-1}\right) * 20.33 \mathrm{~J} \mathrm{ml}^{-1} \mathrm{O}_{2}$ 
The SFG reflects the energy available for somatic and reproductive growth. A positive SFG reflects a net energy gain which is available for growth, while a negative SFG reflects a net energy loss.

\section{Statistical analysis}

For each species a mutlivariate backward stepwise regression analysis (critical $\alpha=0.15$ ) was conducted for $\mathrm{CR}_{\mathrm{s}}$, AE and SFG against all seston characteristics (TPM, POM, PCOM, Chlorophyll $a$, particle count) to find which combination explained maximal variation in $\mathrm{CR}_{\mathrm{s}}, \mathrm{AE}$ or SFG. Pearson correlation analyses were conducted to ascertain which seston characteristics explained most variation of $\mathrm{CR}_{\mathrm{s}} \mathrm{AE}$ and $\mathrm{SFG}$ in each species. All analysis was carried out using SYSTAT 9.0 statistical software. Comparisons of physiological responses among-species are outside the scope of this research and were not examined, the primary focus of this work was to examine SFG in each species.

\subsection{Results}

\section{Seston characteristics}

As experiments were run at different times of the year, the nature of the seston changed according to the season. Values of TPM, POM, PCOM were highest in winter, values for chlorophyll $a$ and particle count were highest in spring (Table 5.1). All values were lowest in the summer. These data include those recorded for the southerly storm event in the A. maoriana winter experiment. An additional entry has been made in the Table 5.1 (winter*) which shows the winter data without these observations.

Table 5.1. Seston characteristics in feeding experiments, winter* denotes data without repeated storm event in A. maoriana experiment.

\begin{tabular}{l|lccccc}
\hline \multicolumn{2}{c}{} & $\begin{array}{c}\text { Total } \\
\text { particulate } \\
\text { matter }\left(\mathrm{mg} \mathrm{l}^{-1}\right)\end{array}$ & $\begin{array}{c}\text { Particulate } \\
\text { organic matter } \\
\left(\mathrm{mg} \mathrm{l}^{-1}\right)\end{array}$ & $\begin{array}{c}\text { Percent } \\
\text { organic } \\
\text { matter }\end{array}$ & $\begin{array}{c}\text { Chlorophyll } \\
a\left(\mu \mathrm{l}^{-1}\right)\end{array}$ & $\begin{array}{c}\text { Particle } \\
\text { number } \\
\left(>2.5 \mu \mathrm{ml}^{-1}\right)\end{array}$ \\
\hline \multirow{2}{*}{ Winter } & Mean & 16.54 & 4.15 & 24.98 & 0.042 & 19387 \\
& SD & 9.37 & 2.64 & 5.93 & 0.029 & 12797 \\
\multirow{5}{*}{ Summer } & Mean & 12.07 & 2.53 & 21.00 & 0.027 & 10571 \\
& SD & 0.81 & 0.21 & 1.70 & 0.015 & 4901 \\
& Mean & 13.13 & 3.10 & 24.0 & 0.056 & 28997 \\
Winter* & SD & 2.66 & 0.73 & 58.6 & 0.043 & 32195 \\
& Mean & 11.22 & 2.61 & 24.44 & 0.027 & 13444 \\
& SD & 3.05 & 0.71 & 5.35 & 0.010 & 6778 \\
\hline
\end{tabular}




\subsubsection{Oxygen consumption}

In the low temperature experiments, $M$. galloprovincialis had the highest oxygen consumption rate $\left(0.324 \mathrm{ml} \mathrm{O}_{2} \mathrm{~g}^{-1} \mathrm{~h}^{-1}\right)$, followed by $P$. canaliculus $\left(0.256 \mathrm{ml} \mathrm{O}_{2} \mathrm{~g}^{-1} \mathrm{~h}^{-}\right.$ $\left.{ }^{1}\right)$ and A. maoriana (0.231 $\mathrm{ml} \mathrm{O}_{2} \mathrm{~g}^{-1} \mathrm{~h}^{-1}$ ) (Table 5.2 \& Figs. 5.1). Of the three species only $P$. canaliculus showed a significant increase in oxygen consumption rate at the higher temperature $(\mathrm{t}=3.371$, d.f.=19). Similar oxygen consumption rates for $A$. maoriana and M. galloprovincialis were recorded at both high and low temperature experiments (Table 5.3 \& Fig. 5.1). All species displayed a significant $(\mathrm{p}<0.001)$ correlation between oxygen consumption rate and dry body weight in the low temperature experiment (Fig. 5.1 \& Table 5.1). Although only six mussels were used in the high temperature experiments (Table 5.3) correlations between log oxygen consumption rate and log dry weight were significant for $P$. canaliculus $(\mathrm{p}=0.004)$ and A. maoriana ( $\mathrm{p}=0.015)$, but not for $M$. galloprovincialis $(\mathrm{p}=0.058)$. A summary of the data collected for all three species appears in Table 5.2 for low temperature experiments and Table 5.3 for high temperature experiments.

Table 5.2. Summary of low temperature oxygen consumption data for 15 mussels. $\mathrm{VO}_{2}$ is the mean $( \pm \mathrm{SD})$ of log transformed weight standardised mussels. The regression and linear equation shows the relationship between log dry weight $(\mathrm{g})$ and $\log \mathrm{VO}_{2}\left(\mathrm{ml} \mathrm{O}_{2} \mathrm{hr}^{-1}\right)$; Energy $( \pm \mathrm{SD})$ refers to the energy equivalent of $\mathrm{VO}_{2}$.

\begin{tabular}{l|cccc}
\hline Species & $\mathrm{VO}_{2}\left(\mathrm{ml} \mathrm{O}_{2} \mathrm{~g}^{-1} \mathrm{hr}^{-1}\right)$ & $\mathrm{R}^{2}$ & $\mathrm{Y}=\mathrm{a}(\mathrm{x})+\mathrm{b}$ & ${\text { Energy }\left(\mathrm{J} \mathrm{g}^{-1} \mathrm{~h}^{-1}\right)}$ \\
\hline P. canaliculus & $0.256(0.050)$ & 0.849 & $0.946(\mathrm{x})-0.599$ & $5.214(1.020)$ \\
A. maoriana & $0.231(0.049)$ & 0.868 & $0.089(\mathrm{x})-0.645$ & $4.696(0.989)$ \\
M. galloprovincialis & $0.324(0.099)$ & 0.734 & $0.827(\mathrm{x})-0.509$ & $6.577(2.010)$ \\
\hline
\end{tabular}

Table 5.3. Summary of high temperature oxygen consumption data for 6 mussels. VO2 is the mean $( \pm \mathrm{SD})$ of log transformed weight standardised mussels. The regression and linear equation shows the relationship between log dry weight $(\mathrm{g})$ and $\log \mathrm{VO}_{2}\left(\mathrm{ml} \mathrm{O}_{2} \mathrm{hr}^{-1}\right)$; Energy $( \pm \mathrm{SD})$ refers to the energy equivalent of $\mathrm{VO}_{2}$.

\begin{tabular}{l|cccc}
\hline Species & $\mathrm{VO}_{2}\left(\mathrm{ml} \mathrm{O}_{2} \mathrm{~g}^{-1} \mathrm{hr}^{-1}\right)$ & $\mathrm{R}^{2}$ & $\mathrm{Y}=\mathrm{a}(\mathrm{x})+\mathrm{b}$ & Energy $\left(\mathrm{J} \mathrm{g}^{-1} \mathrm{~h}^{-1}\right)$ \\
\hline P. canaliculus & $0.344(0.064)$ & 0.898 & $0.920(\mathrm{x})-0.470$ & $7.001(1.294)$ \\
A. maoriana & $0.229(0.026)$ & 0.808 & $0.832(\mathrm{x})-0.642$ & $4.663(0.525)$ \\
M. galloprovincialis & $0.318(0.045)$ & 0.633 & $0.774(\mathrm{x})-0.501$ & $6.463(0.928)$ \\
\hline
\end{tabular}



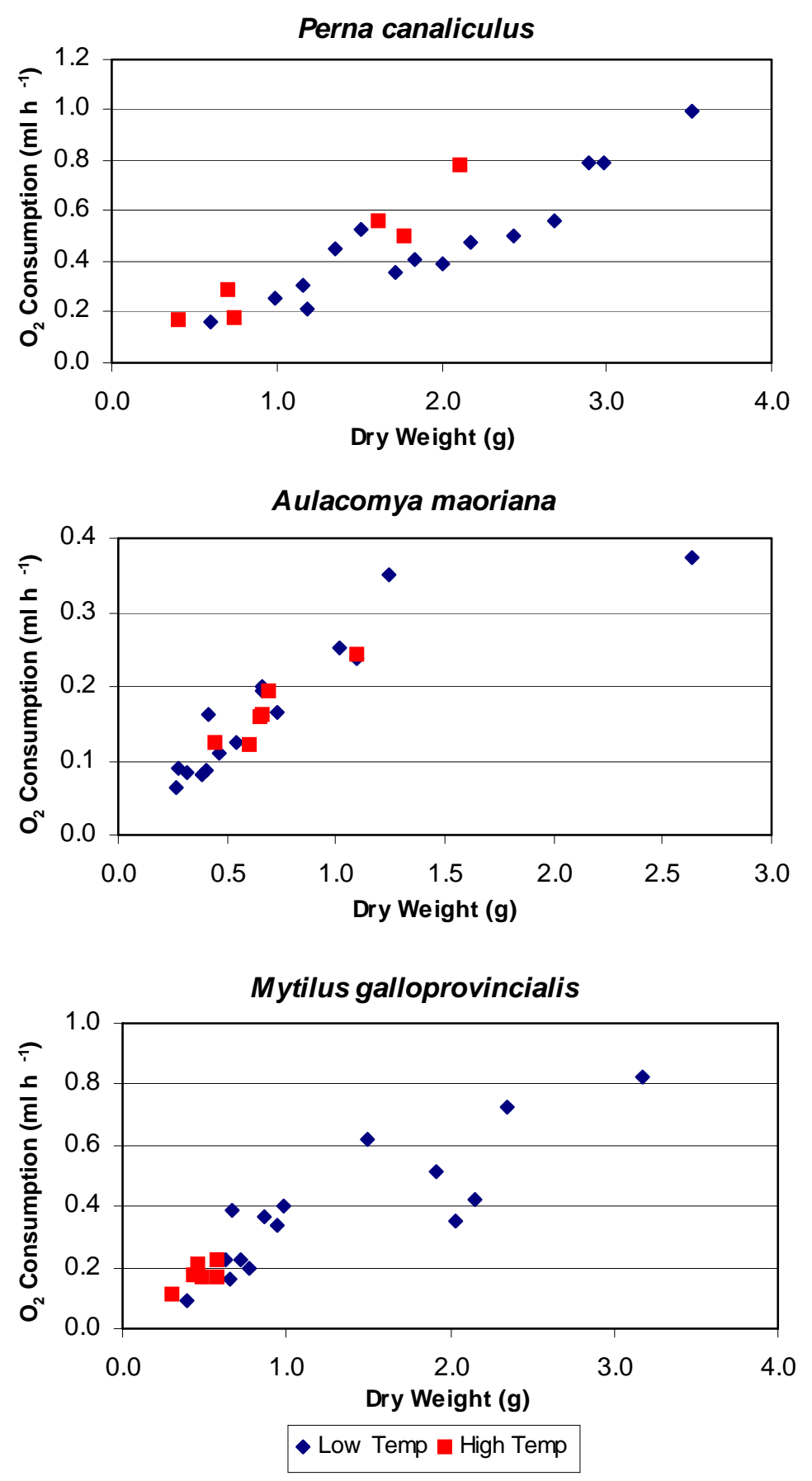

Figure 5.1. Comparison between low temperature and high temperature oxygen consumption rates in all three mussel species.

\section{Oxygen consumption of animals held long-term at IBML}

Of the three species in this study, only M. galloprovincialis showed a noticeable decrease in oxygen consumption rate when held at IBML for 10 wk compared to low temperature oxygen consumption rates. A. maoriana displayed a smaller decrease, while P. canaliculus remained virtually the same (Table 5.4). Oxygen consumption in M. galloprovincialis dropped from 0.324 to $0.223 \mathrm{ml} \mathrm{O}_{2} \mathrm{~g}^{-1} \mathrm{~h}^{-1}$. A. maoriana dropped 
from 0.231 to $0.195 \mathrm{ml} \mathrm{O}_{2} \mathrm{~g}^{-1} \mathrm{~h}^{-1}$. It is interesting to note however that a very poor correlation now exists between log dry weight and log oxygen consumption rate. $P$. canaliculus fell from an $\mathrm{R}^{2}$ of 0.849 to 0.097 , A. maoriana from 0.868 to 0.021 and M. galloprovincialis from 0.734 to 0.368 (Fig.5.2).

Table 5.4. Standardised oxygen consumption data (mean \pm SD) for mussels held at IBML for an extended period. The regression and linear equation shows the relationship between log dry weight (g) and $\log \mathrm{VO}_{2}\left(\mathrm{ml} \mathrm{O}_{2} \mathrm{hr}^{-1}\right)$; Energy (mean $\pm \mathrm{SD}$ ) refers to the energy equivalent of $\mathrm{VO}_{2}$..

\begin{tabular}{l|ccccc}
\hline Species & $\begin{array}{c}\mathrm{VO}_{2} \\
\left(\mathrm{ml} \mathrm{O}_{2} \mathrm{~g}^{-1} \mathrm{~h}^{-1}\right)\end{array}$ & $\mathrm{R}^{2}$ & $n$ & $\mathrm{Y}=\mathrm{a}(\mathrm{x})+\mathrm{b}$ & $\begin{array}{c}\text { Energy } \\
\left(\mathrm{J} \mathrm{g} \mathrm{h}^{-1}\right)\end{array}$ \\
\hline P. canaliculus & $0.260(0.081)$ & 0.097 & 6 & $0.1977(\mathrm{x})-0.603$ & $5.293(1.643)$ \\
A. maoriana & $0.195(0.087)$ & 0.021 & 10 & $0.2316(\mathrm{x})-0.884$ & $3.956(1.758)$ \\
M. galloprovincialis & $0.223(0.063)$ & 0.368 & 6 & $0.4281(\mathrm{x})-0.667$ & $4.531(1.283)$ \\
\hline
\end{tabular}

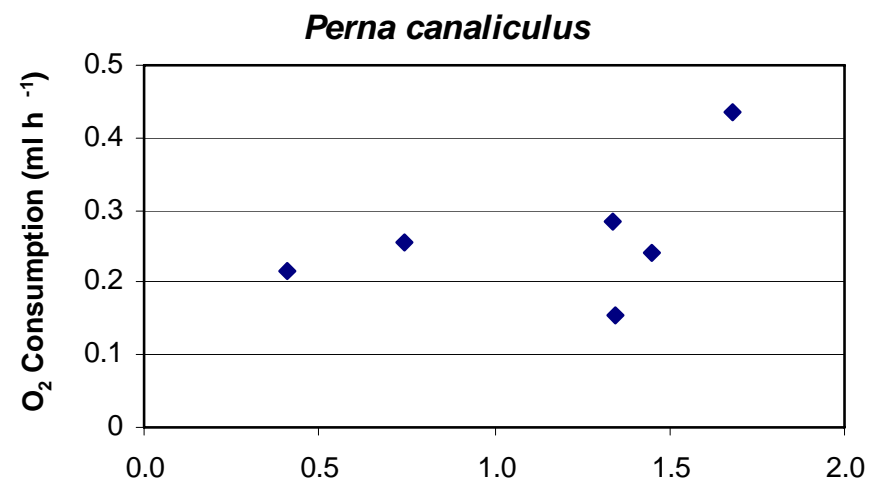

Aulacomya maoriana

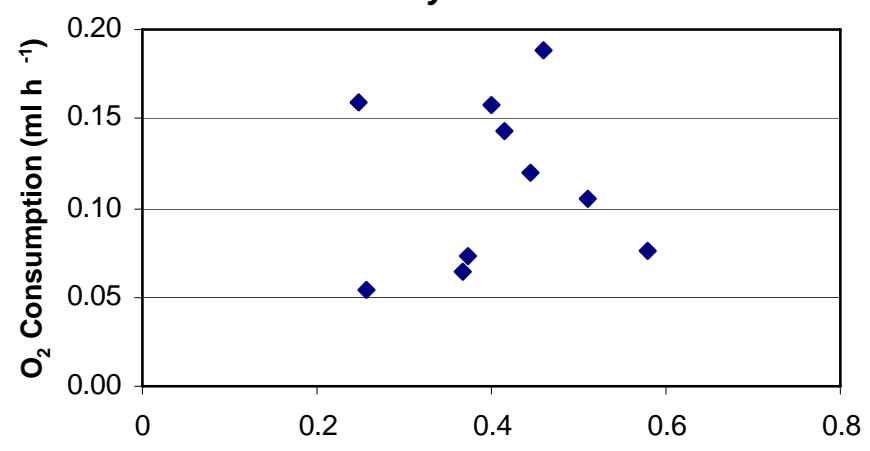

Mytilus galloprovincialis

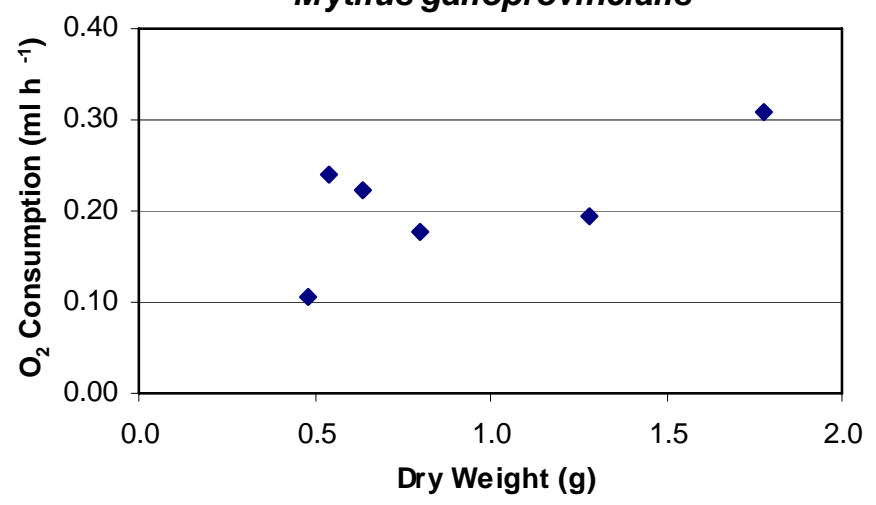

Figure 5.2. Relationship between dry tissue weight and oxygen consumption rate in all three mussel species held at IBML for ten weeks. 
Given the vast variation in study conditions in the literature it is very difficult to compare values between studies. It appears that the values in this study are comparable to those from published data (Table 5.5).

Table 5.5. Published estimates of oxygen consumption rates converted to one gram standard dry weight unless otherwise stated.

\begin{tabular}{l|cl}
\hline Species & $\mathrm{VO}_{2}\left(\mathrm{ml} \mathrm{g}^{-1} \mathrm{~h}^{-1}\right)$ & Author \\
\hline P. perna & 0.447 & van Erkom Schurink \& Griffiths, 1992 \\
P. canaliculus & $0.2-0.3$ & Marsden \& Weatherhead, 1998 \\
P. canaliculus & 0.45 & Gardner \& Thompson, 2001 \\
P. canaliculus & 0.256 & This study \\
A. ater & $0.206-0.231$ & Stuart, 1982 \\
A. ater & 0.262 & van Erkom Schurink \& Griffiths, 1992 \\
A. maoriana & 0.231 & This study \\
Mytilus edulis & 0.540 & Okumu• \& Sterling, 1992 \\
Mytilus edulis & 0.228 & Widdows \& Johnson, 1988 \\
M. galloprovincialis & $0.439-0.502$ & Navarro et al., 1991 \\
M. galloprovincialis & 0.436 & van Erkom Schurink \& Griffiths, 1992 \\
M. galloprovincialis & 0.324 & This study \\
\hline
\end{tabular}

1. Standardised to dry weight $0.75 \mathrm{~g}$.

2. $50 \mathrm{~mm}$ size class standardised to $0.54 \mathrm{~g}$.

\subsubsection{Clearance Rate (CR)}

\section{P. canaliculus}

The mean $( \pm \mathrm{SD}) \mathrm{CR}_{\mathrm{s}}$ of all observations was $3.34 \mathrm{lg}^{-1} \mathrm{~h}^{-1},( \pm 1.48)$. Mean $\mathrm{CR}_{\mathrm{s}}$ among experiments ranged from $1.19-4.60 \mathrm{l} \mathrm{g}^{-1} \mathrm{~h}^{-1}$; two of the larger $\mathrm{CR}_{\mathrm{s}}$ values being observed at times of high organic content in the seston in June 1998 and September 2000 (Table 5.6). Significant correlations existed between $\mathrm{CR}_{\mathrm{s}}$ and each of TPM, POM and particle count (Table 5.7). Figures of $\mathrm{CR}_{\mathrm{s}}$ and seston characteristics for $P$. canaliculus appear in Appendix B1. 
Table 5.6. Mean corrected clearance rate $\left(\mathrm{CR}_{\mathrm{s}}\right)$, absorption efficiency (AE) and seston characteristics (TPM, POM, PCOM and Chlorophyll $a$ ) for $P$. canaliculus experiments; data are the mean of 12 observations on each given experimental date.

\begin{tabular}{l|ccccccc}
\hline \multicolumn{1}{c|}{ Date } & $\begin{array}{c}\mathrm{CR}_{\mathrm{s}} \\
\left(\mathrm{l} \mathrm{g}^{-1} \mathrm{~h}^{-1}\right)\end{array}$ & $\mathrm{AE}$ & $\begin{array}{c}\mathrm{TPM} \\
\left(\mathrm{mg} \mathrm{l}^{-1}\right)\end{array}$ & $\begin{array}{c}\text { POM } \\
\left(\mathrm{mg} \mathrm{l}^{-1}\right)\end{array}$ & PCOM & $\begin{array}{c}\text { Chl } a \\
\left.(\mu \mathrm{g} \mathrm{l})^{-1}\right)\end{array}$ & $n$ \\
\hline Jun 98 & $1.19(0.33)$ & $-0.021(0.286)$ & 5.6 & 1.35 & 24.1 & 0.0362 & 12 \\
Jun 98 & $4.14(1.19)$ & $0.626(0.100)$ & 15.3 & 4.50 & 29.4 & 0.0228 & 12 \\
Mar 99 & $3.78(0.93)$ & $-0.012(0.240)$ & 13.3 & 2.60 & 19.5 & 0.0697 & 12 \\
Mar 99 & $4.34(1.31)$ & $0.210(0.070)$ & 13.6 & 2.75 & 20.2 & 0.0349 & 12 \\
Jun 99 & $3.73(1.38)$ & $0.104(0.146)$ & 14.0 & 2.67 & 19.1 & 0.0386 & 12 \\
Jun 99 & $3.33(0.82)$ & $0.127(0.158)$ & 13.4 & 2.70 & 20.1 & 0.0373 & 12 \\
Feb 00 & $1.58(0.63)$ & $0.212(0.108)$ & 12.4 & 2.60 & 21.0 & 0.0178 & 12 \\
Feb 00 & $2.92(1.04)$ & $0.083(0.122)$ & 12.2 & 2.87 & 23.4 & 0.0237 & 12 \\
Sept 00 & $4.60(1.30)$ & $0.274(0.118)$ & 12.1 & 4.20 & 34.7 & 0.0211 & 12 \\
Sept 00 & $3.82(0.96)$ & $0.069(0.202)$ & 11.3 & 2.00 & 17.7 & 0.0350 & 12 \\
\hline Mean & 3.343 & 0.167 & 12.3 & 2.82 & 22.9 & 0.0337 & \\
\hline
\end{tabular}

Table 5.7. Correlations between $\mathrm{CR}_{\mathrm{s}}$ and individual seston variables for $P$. canaliculus.

\begin{tabular}{l|ccc}
\hline & $\mathrm{R}^{2}$ & $\mathrm{p}$-value & $n$ \\
\hline TPM & 0.259 & $<0.001$ & 117 \\
POM & 0.216 & $<0.001$ & 117 \\
PCOM & 0.025 & 0.088 & 117 \\
Chlorophyll $a$ & 0.011 & 0.254 & 117 \\
Particle Count & 0.043 & 0.026 & 117 \\
\hline
\end{tabular}

A backward stepwise multiple regression ( $\alpha$-critical=0.15) using all seston characteristics (TPM, POM, PCOM, chlorophyll $a$ and particle count) identified TPM, PCOM and chlorophyll $a$ as explaining the most variation in $\mathrm{CR}_{\mathrm{S}}\left(\mathrm{R}^{2}=0.330\right)$. These data give the following equation as the best predictor of clearance rate in $P$. canaliculus (Table 5.8).

P. canaliculus $\mathrm{CR}_{\mathrm{s}}=0.3 *(\mathrm{TPM})+8.517 *(\mathrm{PCOM})+25.966 *(\mathrm{Chl} a)-3.188$

Table 5.8. Multiple regression analysis of $\mathrm{CR}_{\mathrm{s}}$ and seston data for $P$. canaliculus.

\begin{tabular}{l|ccc}
\hline & Coefficient & F-value & p-value \\
\hline Constant & -3.188 & 10.472 & 0.002 \\
Total Particulate Matter & 0.300 & 44.598 & $<0.001$ \\
Percent Organic Matter & 8.517 & 10.644 & 0.001 \\
Chlorophyll $a$ & 25.966 & 7.935 & 0.006 \\
\hline
\end{tabular}




\section{A. maoriana}

The mean $( \pm \mathrm{SD}) \mathrm{CR}_{\mathrm{S}}$ of all observations for A. maoriana was $1.95 \mathrm{l} \mathrm{g}^{-1} \mathrm{~h}^{-1}( \pm 0.936)$ (Table 5.9). Mean $\mathrm{CR}_{\mathrm{s}}$ rate among experiments ranged from 0.77-3.02 $\mathrm{lg}^{-1} \mathrm{~h}^{-1}$. An analysis of correlations between $\mathrm{CR}_{\mathrm{S}}$ and seston characteristics found only PCOM explained significant variation in $\mathrm{CR}_{\mathrm{s}}$ (Table 5.10), although this explains very little variation in $\mathrm{CR}_{\mathrm{S}}\left(\mathrm{R}^{2}=0.02\right)$. Figures of $\mathrm{CR}_{\mathrm{s}}$ and seston characteristics for $A$. maoriana appear in Appendix B2.

Table 5.9. Mean corrected clearance rate $\left(\mathrm{CR}_{\mathrm{s}}\right)$, absorption efficiency (AE) and seston characteristics (TPM, POM, PCOM, chlorophyll $a$ and particle count) for A. maoriana; data are the mean of 12 observations on each given experimental date.

\begin{tabular}{l|ccccccc}
\hline \multicolumn{1}{c|}{ Date } & $\begin{array}{c}\mathrm{CR}_{\mathrm{s}} \\
\left(\mathrm{l} \mathrm{g}^{-1} \mathrm{~h}^{-1}\right)\end{array}$ & $\mathrm{AE}$ & $\begin{array}{c}\mathrm{TPM} \\
\left(\mathrm{mg} \mathrm{l}^{-1}\right)\end{array}$ & $\begin{array}{c}\text { POM } \\
\left(\mathrm{mg} \mathrm{l}^{-1}\right)\end{array}$ & PCOM & $\begin{array}{c}\mathrm{Chl} a \\
\left(\mu \mathrm{g} \mathrm{l}^{-1}\right)\end{array}$ & $n$ \\
\hline Jun 98 & $2.66(0.66)$ & $0.126(0.119)$ & 7.4 & 2.10 & 28.4 & 0.0297 & 12 \\
Jun 98 & $2.22(0.63)$ & $0.172(0.112)$ & 8.5 & 2.90 & 34.2 & 0.0222 & 12 \\
Jun 98 & $2.44(1.07)$ & $0.172(0.112)$ & 23.0 & 9.00 & 39.1 & 0.0485 & 12 \\
Jun 98 & $2.21(0.45)$ & $0.165(0.209)$ & 36.8 & 9.50 & 25.8 & 0.0959 & 12 \\
Jun 98 & $3.02(0.63)$ & $0.165(0.209)$ & 31.8 & 6.40 & 20.1 & 0.0959 & 12 \\
Jun 98 & $0.92(0.71)$ & $0.310(0.113)$ & 25.5 & 6.50 & 25.5 & 0.0417 & 12 \\
Jun 98 & $1.22(0.50)$ & $0.401(0.068)$ & 33.1 & 8.70 & 26.3 & 0.1062 & 12 \\
Mar 99 & $2.88(0.91)$ & $-0.403(0.250)$ & 12.2 & 2.15 & 17.6 & 0.0236 & 12 \\
Mar 99 & $0.77(0.32)$ & $0.022(0.196)$ & 12.3 & 2.50 & 20.3 & 0.0347 & 12 \\
Jun 99 & $2.30(0.53)$ & $-0.092(0.291)$ & 12.1 & 2.60 & 21.5 & 0.0144 & 12 \\
Jun 99 & $1.72(0.58)$ & $-0.227(0.165)$ & 14.3 & 2.30 & 16.1 & 0.0436 & 12 \\
Feb 00 & $1.24(0.45)$ & $0.379(0.110)$ & 11.3 & 2.40 & 21.2 & 0.0248 & 12 \\
Feb 00 & $1.68(0.69)$ & $-0.167(0.135)$ & 11.4 & 2.65 & 23.3 & 0.0193 & 12 \\
Sept 00 & $1.39(0.62)$ & $-0.162(0.334)$ & 18.3 & 3.55 & 19.4 & 0.0812 & 12 \\
Sept 00 & $2.32(0.91)$ & $0.105(0.352)$ & 12.0 & 3.45 & 28.8 & 0.0417 & 12 \\
\hline Mean & 1.93 & 0.081 & 18.0 & 4.45 & 24.5 & 0.0482 & \\
\hline
\end{tabular}

Table 5.10. Correlations between $\mathrm{CR}_{\mathrm{s}}$ and individual seston variables for $A$. maoriana.

\begin{tabular}{l|ccc}
\hline & $\mathrm{R}^{2}$ & $\mathrm{p}$-value & $n$ \\
\hline TPM & 0.0002 & 0.873 & 171 \\
POM & 0.0018 & 0.581 & 171 \\
PCOM & 0.0195 & 0.038 & 171 \\
Chlorophyll $a$ & $<0.000$ & 0.913 & 171 \\
Particle Count & 0.0056 & 0.332 & 171 \\
\hline
\end{tabular}

A backward stepwise regression analysis ( $\alpha$-critical=0.15) using all seston characteristics (TPM, POM, PCOM, chlorophyll $a$ and particle count) showed that POM, TPM and PCOM explained most variation in clearance rate. However, the model did not fit particularly well $\left(\mathrm{R}^{2}=0.066\right)$. Table 5.11 gives the regression data, and hence the following predictive equation:

$$
\text { A. maoriana } \mathrm{CR}_{\mathrm{s}}=-0.466 *(\mathrm{POM})+0.119 *(\mathrm{TPM})+10.363 *(\mathrm{PCOM})-0.655
$$


Table 5.11. Multiple regression analysis of $\mathrm{CR}_{\mathrm{s}}$ and seston variables for A. maoriana.

\begin{tabular}{l|ccc}
\hline & Coefficient & F-value & p-value \\
\hline Constant & -0.655 & 0.663 & 0.417 \\
Particulate Organic Matter & -0.466 & 7.322 & 0.008 \\
Total Particulate Matter & 0.119 & 7.161 & 0.008 \\
Percent Organic Matter & 10.363 & 10.818 & 0.001 \\
\hline
\end{tabular}

\section{M. galloprovincialis}

The mean $( \pm \mathrm{SD}) \mathrm{CR}_{\mathrm{s}}$ of all observation for M. galloprovincialis was $2.52 \mathrm{l} \mathrm{g}^{-1} \mathrm{~h}^{-1}$ ( \pm 1.540 ). Mean $\mathrm{CR}_{\mathrm{s}}$ among experiments ranged from 1.19-5.00 $\mathrm{g}^{-1} \mathrm{~h}^{-1}$ (Table 5.12). An analysis of correlations between $\mathrm{CR}_{\mathrm{s}}$ and all seston characteristics found that TPM, POM, Chlorophyll $a$ and particle count all explained significant variation in $\mathrm{CR}_{\mathrm{s}}$ (Table 5.13). Figures of $\mathrm{CR}_{\mathrm{s}}$ and seston characteristics for M. galloprovincialis appear in Appendix B3.

Table 5.12. Mean corrected clearance rate $\left(\mathrm{CR}_{s}\right)$, absorption efficiency (AE) and seston characteristics (TPM, POM, PCOM, chlorophyll $a$ and particle count) for M. galloprovincialis; data are the mean of 12 observations on each given experimental date.

\begin{tabular}{l|ccccccc}
\hline \multicolumn{1}{c|}{ Date } & $\begin{array}{c}\mathrm{CR}_{\mathrm{s}} \\
\left(\mathrm{l} \mathrm{g}^{-1} \mathrm{~h}^{-1}\right)\end{array}$ & $\mathrm{AE}$ & $\begin{array}{c}\mathrm{TPM} \\
\left(\mathrm{mg} \mathrm{l}^{-1}\right)\end{array}$ & $\begin{array}{c}\text { POM } \\
\left(\mathrm{mg} \mathrm{l}^{-1}\right)\end{array}$ & PCOM & $\begin{array}{c}\text { Chl } a \\
\left(\mu \mathrm{l} \mathrm{l}^{-1}\right)\end{array}$ & $n$ \\
\hline Jun 98 & $1.62(0.86)$ & $-0.172(0.219)$ & 9.2 & 2.10 & 22.8 & 0.034 & 12 \\
Jun 98 & $2.20(0.91)$ & $-0.050(0.257)$ & 9.1 & 2.80 & 30.8 & 0.020 & 12 \\
Mar 99 & $1.19(0.47)$ & $0.010(0.184)$ & 11.9 & 2.40 & 20.2 & 0.017 & 12 \\
Mar 99 & $2.52(1.59)$ & $0.007(0.193)$ & 11.3 & 2.45 & 21.7 & 0.017 & 12 \\
Jun 99 & $3.07(0.97)$ & $0.203(0.079)$ & 12.1 & 2.65 & 21.9 & 0.012 & 12 \\
Jun 99 & $3.11(0.91)$ & $-0.158(0.132)$ & 14.1 & 2.60 & 18.4 & 0.017 & 12 \\
Feb 00 & $1.46(0.74)$ & $0.062(0.136)$ & 11.5 & 2.75 & 23.9 & 0.014 & 12 \\
Feb 00 & $2.95(1.60)$ & $0.119(0.152)$ & 10.7 & 2.15 & 20.0 & 0.024 & 12 \\
Sept 00 & $5.00(2.05)$ & $0.190(0.189)$ & 14.4 & 3.05 & 21.3 & 0.142 & 12 \\
Sept 00 & $1.88(0.74)$ & $0.077(0.232)$ & 10.6 & 2.45 & 23.1 & 0.020 & 12 \\
\hline Mean & 2.50 & 0.051 & 11.5 & 2.54 & 22.4 & 0.032 & \\
\hline
\end{tabular}

Table 5.13. Correlations between $\mathrm{CR}_{\mathrm{s}}$ and individual seston variables for $M$. galloprovincialis.

\begin{tabular}{l|ccc}
\hline & $\mathrm{R}^{2}$ & $\mathrm{p}$-value & $n$ \\
\hline TPM & 0.216 & $<0.001$ & 109 \\
POM & 0.163 & $<0.001$ & 109 \\
PCOM & 0.031 & 0.068 & 109 \\
Chlorophyll $a$ & 0.263 & $<0.001$ & 109 \\
Particle Count & 0.322 & $<0.001$ & 109 \\
\hline
\end{tabular}

As with the other species, a backward stepwise regression analysis $(\alpha$-critical $=0.15$ ) was performed on seston data. TPM, POM, PCOM chlorophyll $a$ and particle count were included in the initial model. All data were discarded from the model with the 
exception of TPM and particle count (Table 5.14). The data from the regression analysis $\left(\mathrm{R}^{2}=0.337\right)$ give the following predictive equation:

M. galloprovincialis $\mathrm{CR}_{\mathrm{s}}=0.144 *(\mathrm{TPM})+0.001 *($ Particle count $)+0.196$

Table 5.14. Multiple regression analysis of $\mathrm{CR}_{\mathrm{s}}$ and seston for M. galloprovincialis.

\begin{tabular}{l|ccc}
\hline & Coefficient & F-value & p-value \\
\hline Constant & 0.196 & 0.040 & 0.841 \\
Total Particulate Matter & 0.144 & 2.443 & 0.121 \\
Particle Count & 0.001 & 19.430 & $<0.001$ \\
\hline
\end{tabular}

\subsubsection{Absorption Efficiency (AE)}

\section{P. canaliculus}

The mean $( \pm \mathrm{SD}) \mathrm{AE}$ of all observations was $0.1666( \pm 0.2426)$, and a median of 0.1673. Although AE appears to be positive in most cases (Table 5.6), of the 117 animals in these experiments, 25 (21.40\%) had a negative AE. AE was significantly correlated with TPM, POM, PCOM and chlorophyll $a$ (Table 5.15). Figures of AE and seston characteristics for P. canaliculus appear in Appendix B4.

Table 5.15. Correlations between AE and individual seston variables for $P$. canaliculus.

\begin{tabular}{l|ccc}
\hline & $\mathrm{R}^{2}$ & $\mathrm{p}$-value & $n$ \\
\hline TPM & 17.34 & $<0.001$ & 117 \\
POM & 39.53 & $<0.001$ & 117 \\
PCOM & 19.11 & $<0.001$ & 117 \\
Chlorophyll $a$ & 16.5 & $<0.001$ & 117 \\
Particle Count & 0.64 & 0.392 & 117 \\
\hline
\end{tabular}

A backward stepwise multiple regression analysis $(\alpha$-critical $=0.15)$ showed all seston characteristics to be correlated with AE (dry body weight was also included in this analysis) (Table 5.16). The model had an $\mathrm{R}^{2}$ of 0.537 and gave the following prediction equation:

$$
\begin{gathered}
\text { P. canaliculus } \mathrm{AE}=1.723 *(\mathrm{POM})-0.394 *(\mathrm{TPM})-19.67 *(\mathrm{PCOM})-4.246 *(\mathrm{Chl} a)+ \\
0.001 *(\text { Particle Count })+0.036 *(\text { Dry body weight })+4.608
\end{gathered}
$$


Table 5.16. Multiple regression analysis of AE and seston data for $P$. canaliculus.

\begin{tabular}{l|ccc}
\hline & Coefficient & F-value & p-value \\
\hline Constant & 4.608 & 20.876 & $<0.001$ \\
Total Particulate Matter & -0.394 & 27.015 & $<0.001$ \\
Particulate Organic Matter & 1.723 & 21.706 & $<0.001$ \\
Percent Organic Matter & -19.670 & 23.181 & $<0.001$ \\
Chlorophyll $a$ & -4.246 & 8.904 & 0.004 \\
Particle Count & 0.001 & 7.598 & 0.007 \\
Dry body weight & 0.036 & 2.263 & 0.135 \\
\hline
\end{tabular}

\section{A. maoriana}

The mean $( \pm \mathrm{SD}) \mathrm{AE}$ of all observations was $0.0620( \pm 0.2960)$ and a median of 0.0890. Mean AE for each experiment was usually positive (Table 5.9) although of the 171 observations of AE, 59 (34.5\%) were negative. Significant correlations existed between AE and TPM, POM, PCOM and chlorophyll $a$ (Table 5.17). Figures of $\mathrm{AE}$ and seston characteristics for A. maoriana appear in Appendix B5.

Table 5.17. Correlations between AE and individual seston variables for A. maoriana.

\begin{tabular}{l|ccc}
\hline & $\mathrm{R}^{2}$ & $\mathrm{p}$-value & $n$ \\
\hline TPM & 0.088 & $<0.001$ & 171 \\
POM & 0.149 & $<0.001$ & 171 \\
PCOM & 0.139 & $<0.001$ & 171 \\
Chlorophyll $a$ & 0.060 & 0.001 & 171 \\
Particle Count & 0.0004 & 0.805 & 171 \\
\hline
\end{tabular}

A backwards stepwise multiple regression analysis was conducted ( $\alpha$-critical $=0.15)$. This included all seston characteristics and dry body weight. The analysis retained PCOM, chlorophyll $a$, particle count and dry body weight $\left(\mathrm{R}^{2}=0.310\right)$ (Table 5.18). The predictive equation is as follows:

$$
\begin{gathered}
\text { A. maoriana } \mathrm{AE}=1.580 *(\mathrm{PCOM})+7.026 *(\mathrm{Chl} a)-0.001 *(\text { Particle count })+0.134 *(\text { Dry } \\
\text { weight })-0.57
\end{gathered}
$$

Table 5.18. Regression analysis results on AE for A. maoriana.

\begin{tabular}{l|ccc}
\hline & Coefficient & F-value & p-value \\
\hline Constant & -0.570 & 31.923 & $<0.001$ \\
Percent Organic Matter & 1.580 & 24.830 & $<0.001$ \\
Chlorophyll $a$ & 7.026 & 40.424 & $<0.001$ \\
Particle Count & -0.001 & 23.002 & $<0.001$ \\
Dry body weight & 0.134 & 3.460 & 0.065 \\
\hline
\end{tabular}




\section{M. galloprovincialis}

The mean $( \pm \mathrm{SD})$ AE of all observations was $0.0230( \pm 0.2194)$ and a median of 0.0610. Table 5.12 shows mean AE is positive during most experiments, however of the 109 values 45 (41.3\%) were negative. Significant correlations were observed between AE and POM and chlorophyll $a$ (Table 5.19). Figures of AE and seston characteristics for M. galloprovincialis appear in Appendix B6.

Table 5.19. Correlations between AE and individual seston variables for M. galloprovincialis.

\begin{tabular}{l|ccc}
\hline & $\mathrm{R}^{2}$ & $\mathrm{p}$-value & $n$ \\
\hline TPM & 0.0305 & 0.069 & 109 \\
POM & 0.0600 & 0.010 & 109 \\
PCOM & 0.0018 & 0.665 & 109 \\
Chlorophyll $a$ & 0.0418 & 0.033 & 109 \\
Particle Count & 0.0221 & 0.122 & 109 \\
\hline
\end{tabular}

A backward stepwise multiple regression analysis $(\alpha$-critical $=0.15)$ was performed which included all seston characteristics and dry body weight (Table 5.20). The model $\left(\mathrm{R}^{2}=0.274\right)$ retained all variables except TPM (Table 5.20) and gave a predictive equation as follows:

M. galloprovincialis $\mathrm{AE}=0.484 *(\mathrm{POM})-2.373 *(\mathrm{PCOM})+7.634 *(\mathrm{Chl} a)-0.001 *($ Particle count $)+0.255 *($ Dry body weight $)-0.745$

Table 5.20. Regression analysis results on AE for M. galloprovincialis.

\begin{tabular}{l|ccc}
\hline & Coefficient & F-value & p-value \\
\hline Constant & -0.745 & 11.655 & 0.001 \\
Particulate Organic Matter & 0.484 & 19.885 & $<0.001$ \\
Percent Organic Matter & -2.373 & 9.515 & 0.003 \\
Chlorophyll $a$ & 7.634 & 17.206 & $<0.001$ \\
Particle Count & 0.001 & 18.436 & $<0.001$ \\
Dry body weight & 0.255 & 10.471 & 0.002 \\
\hline
\end{tabular}

\subsubsection{Scope for Growth (SFG)}

ANOVA indicated that there were significant differences in SFG among species $\left(\mathrm{R}^{2}=0.065, \mathrm{~F}=13.626, \mathrm{p}<0.001\right)$. SFG values were highest for $P$. canaliculus, followed by A. maoriana and M. galloprovincialis. Further analyses were therefore conducted separately on each species. 


\section{P. canaliculus}

The mean $( \pm \mathrm{SD})$ SFG of all observations was $45.63 \mathrm{~J} \mathrm{~g}^{-1} \mathrm{~h}^{-1}( \pm 78.85)$, and the median was $23.47 \mathrm{~J} \mathrm{~g}^{-1} \mathrm{~h}^{-1}$. P. canaliculus had a positive mean SFG on all but two occasions, although high variation exists (Table 5.21). Of the eight experiments that had positive SFG, four had standard deviations that overlapped zero. Although mean SFG was positive for 9 of the 12 experiments, of the 109 animals in the experiment 29 (26.6\%) had a negative SFG. On two occasions (June 1998 and September 2000) very high SFG values were observed, coinciding with high levels of organic material in the seston (Table 5.6). Correlation analysis identified TPM, POM, PCOM and chlorophyll $a$ as explaining significant variation in SFG (Table 5.22). Figures of SFG and seston characteristics for P. canaliculus appear in Appendix B7.

Table 5.21. Components of the energy budget (mean $\pm \mathrm{SD}$ ) and scope for growth for $P$. canaliculus.

\begin{tabular}{l|cccc}
\hline Date & $\begin{array}{c}\text { Energy } \\
\text { Consumed, C } \\
\left(\mathrm{J} \mathrm{g}^{-1} \mathrm{~h}^{-1}\right)\end{array}$ & $\begin{array}{c}\text { Energy } \\
\text { Absorbed, A } \\
\left(\mathrm{J} \mathrm{g}^{-1} \mathrm{~h}^{-1}\right)\end{array}$ & $\begin{array}{c}\text { Energy } \\
\text { Respired, R } \\
\left(\mathrm{J} \mathrm{g}^{-1} \mathrm{~h}^{-1}\right)\end{array}$ & $\begin{array}{c}\text { SFG } \\
\left(\mathrm{J} \mathrm{g}^{-1} \mathrm{~h}^{-1}\right)\end{array}$ \\
\hline Jun 98 & $36.79(10.18)$ & $-0.13(10.16)$ & 5.214 & $-5.35(10.15)$ \\
Jun 98 & $380.78(113.21)$ & $233.37(67.05)$ & 5.214 & $228.16(67.05)$ \\
Mar 99 & $200.80(50.73)$ & $-2.14(53.34)$ & 5.214 & $-7.35(53.34)$ \\
Mar 99 & $255.49(76.40)$ & $56.91(27.33)$ & 5.214 & $51.70(27.33)$ \\
Jun 99 & $210.92(82.87)$ & $25.10(28.01)$ & 5.214 & $19.88(28.01)$ \\
Jun 99 & $191.27(51.40)$ & $25.79(30.07)$ & 5.214 & $20.58(30.07)$ \\
Feb 00 & $90.66(37.76)$ & $18.35(11.25)$ & 5.214 & $13.14(11.25)$ \\
Feb 00 & $192.01(68.16)$ & $19.21(27.10)$ & 5.214 & $14.00(27.10)$ \\
Sept 00 & $444.58(125.60)$ & $117.17(50.77)$ & 5.214 & $111.95(50.77)$ \\
Sept 00 & $175.68(44.29)$ & $15.48(32.06)$ & 5.214 & $10.26(32.06)$ \\
\hline
\end{tabular}

Table 5.22. Correlation between SFG and seston for P. canaliculus.

\begin{tabular}{l|ccc}
\hline & $\mathrm{R}^{2}$ & $\mathrm{p}$-value & $n$ \\
\hline TPM & 0.1731 & $<0.001$ & 117 \\
POM & 0.5917 & $<0.001$ & 117 \\
PCOM & 0.3932 & $<0.001$ & 117 \\
Chlorophyll $a$ & 0.1551 & $<0.001$ & 117 \\
Particle Count & 0.0209 & 0.120 & 117 \\
\hline
\end{tabular}

A backward stepwise multiple regression analysis $(\alpha$-critical $=0.15$ ) retained all seston variables and discarded dry body weight (Table 5.23). The model had a good fit $\left(\mathrm{R}^{2}=0.760\right)$ and gave the following predictive equation:

$$
\begin{gathered}
\text { P. canaliculus SFG }=699.2 *(\mathrm{POM})-163.8 *(\mathrm{TPM})-7683.8 *(\mathrm{PCOM})-561.59 *(\mathrm{Chl} a)+ \\
0.005 *(\text { Particle Count })+1803.1
\end{gathered}
$$


Table 5.23. Regression analysis results on Scope for growth for $P$. canaliculus.

\begin{tabular}{l|ccc}
\hline & Coefficient & F-value & p-value \\
\hline Constant & 1803.100 & 59.013 & $<0.001$ \\
Particulate Organic Matter & 699.199 & 82.251 & $<0.001$ \\
Total Particulate Matter & -163.831 & 69.187 & $<0.001$ \\
Percent Organic Matter & -7683.789 & 65.453 & $<0.001$ \\
Chlorophyll $a$ & -561.590 & 2.876 & 0.093 \\
Particle Count & 0.005 & 24.350 & $<0.001$ \\
\hline
\end{tabular}

\section{A. maoriana}

The mean $\left( \pm\right.$ SD) SFG of all observations was $19.1 \mathrm{~J} \mathrm{~g}^{-1} \mathrm{~h}^{-1}( \pm 66.7)$, and the median was $6.36 \mathrm{~J} \mathrm{~g}^{-1} \mathrm{~h}^{-1}$. Energy consumption was higher in June 1998 than at any other time due to a southerly storm (Table 5.24). When the data from this southerly enrichment were excluded the mean $( \pm \mathrm{SD})$ falls to $-7.29 \mathrm{~J} \mathrm{~g}^{-1} \mathrm{~h}^{-1}( \pm 39.97)$ with a median of -3.81 $\mathrm{J} \mathrm{g}^{-1} \mathrm{~h}^{-1}$. Mean SFG was positive in nine of 15 experiments, and of the nine positive SFG values, six had a standard deviation that overlapped zero. Of the 171 animals, 73 (42.7\%) had a negative SFG, which increased to $60.6 \%$ when data from the storm event were excluded. Significant variation in SFG was explained by TPM, POM, PCOM, chlorophyll $a$ (Table 5.25). Figures of SFG and seston characteristics for $A$. maoriana appear in Appendix B8.

Table 5.24. Components of the energy budget (mean $\pm \mathrm{SD}$ ) and scope for growth for $A$. maoriana.

\begin{tabular}{l|cccc}
\hline \multicolumn{1}{c|}{ Date } & $\begin{array}{c}\text { Energy } \\
\text { Consumed, C } \\
\left(\mathrm{J} \mathrm{g}^{-1} \mathrm{~h}^{-1}\right)\end{array}$ & $\begin{array}{c}\text { Energy } \\
\text { Absorbed, A } \\
\left(\mathrm{J} \mathrm{g}^{-1} \mathrm{~h}^{-1}\right)\end{array}$ & $\begin{array}{c}\text { Energy } \\
\text { Respired, R } \\
\left(\mathrm{J} \mathrm{g}^{-1} \mathrm{~h}^{-1}\right)\end{array}$ & $\begin{array}{c}\text { SFG } \\
\left(\mathrm{J} \mathrm{g}^{-1} \mathrm{~h}^{-1}\right)\end{array}$ \\
\hline Jun 98 & $128.33(31.79)$ & $17.00(17.06)$ & 4.696 & $12.3(17.06)$ \\
Jun 98 & $147.79(42.01)$ & $27.00(23.04)$ & 4.696 & $22.30(23.04)$ \\
Jun 98 & $504.19(222.19)$ & $94.00(82.08)$ & 4.696 & $89.30(82.08)$ \\
Jun 98 & $458.35(97.70)$ & $81.85(101.26)$ & 4.696 & $77.15(101.26)$ \\
Jun 98 & $420.89(89.93)$ & $70.72(85.54)$ & 4.696 & $66.02(85.54)$ \\
Jun 98 & $128.79(106.71)$ & $39.90(39.76)$ & 4.696 & $35.20(39.76)$ \\
Jun 98 & $244.73(99.55)$ & $99.27(47.65)$ & 4.696 & $94.57(47.65)$ \\
Mar 99 & $142.34(45.17)$ & $-60.31(47.10)$ & 4.696 & $-65.01(47.10)$ \\
Mar 99 & $35.94(16.64)$ & $0.61(9.039)$ & 4.696 & $-4.09(9.04)$ \\
Jun 99 & $127.45(32.59)$ & $-14.78(42.14)$ & 4.696 & $-19.47(42.14)$ \\
Jun 99 & $82.85(29.51)$ & $-16.99(12.24)$ & 4.696 & $-21.69(12.24)$ \\
Feb 00 & $68.28(24.77)$ & $23.94(5.96)$ & 4.696 & $19.24(5.96)$ \\
Feb 00 & $102.66(42.21)$ & $-16.02(14.87)$ & 4.696 & $-20.71(14.87)$ \\
Sept 00 & $73.68(35.54)$ & $-11.77(21.19)$ & 4.696 & $-16.46(21.19)$ \\
Sept 00 & $184.08(71.81)$ & $17.18(70.74)$ & 4.696 & $12.48(70.74)$ \\
\hline
\end{tabular}


Table 5.25. Correlations between SFG and individual seston variables for A. maoriana.

\begin{tabular}{l|ccc}
\hline & $\mathrm{R}^{2}$ & $\mathrm{p}$-value & $n$ \\
\hline TPM & 0.2521 & $<0.001$ & 171 \\
POM & 0.3512 & $<0.001$ & 171 \\
PCOM & 0.1571 & $<0.001$ & 171 \\
Chlorophyll $a$ & 0.1933 & $<0.001$ & 171 \\
Particle Count & 0.0414 & 0.008 & 171 \\
\hline
\end{tabular}

A backward stepwise multiple regression (critical $\alpha=0.15$ ) was conducted on all seston variables and dry body weight. The model $\left(\mathrm{R}^{2}=0.410\right)$ identified POM, PCOM, chlorophyll $a$ and particle count as explaining significant variation in SFG (Table 5.26). The analysis gave the following predictive equation:

A. maoriana $\mathrm{SFG}=6.02 *(\mathrm{POM})+291.97 *(\mathrm{PCOM})+1064.16 *(\mathrm{Chl} a)-0.001 *(\mathrm{Particle}$ count) -111.55

Table 5.26. Regression results on scope for growth for A. maoriana.

\begin{tabular}{l|ccc}
\hline & Coefficient & F-value & p-value \\
\hline Constant & -111.511 & 26.822 & $<0.001$ \\
Particulate Organic Matter & 6.018 & 3.583 & 0.060 \\
Percent Organic Matter & 291.966 & 10.323 & 0.002 \\
Chlorophyll $a$ & 1064.155 & 9.770 & 0.002 \\
Particle Count & -0.001 & 6.195 & 0.014 \\
\hline
\end{tabular}

\section{M. galloprovincialis}

The mean $( \pm \mathrm{SD})$ SFG of all mussels was $1.26 \mathrm{~J} \mathrm{~g}^{-1} \mathrm{~h}^{-1}( \pm 39.13)$, and the median was $-1.59 \mathrm{~J} \mathrm{~g}^{-1} \mathrm{~h}^{-1}$ (Table 5.27). Of the 109 animals in this experiment, 57 (52.3\%) had negative SFG. Only four of the 10 experiments had positive mean SFG values, three of which had standard deviations that overlapped zero. Significant correlations were found between SFG and POM, chlorophyll $a$, and particle count (Table 5.28). Figures of SFG and seston characteristics for M. galloprovincialis appear in Appendix B9. 
Table 5.27. Components of the energy budget (mean $\pm \mathrm{SD}$ ) and scope for growth for M. galloprovincialis.

\begin{tabular}{l|cccc}
\hline Date & $\begin{array}{c}\text { Energy } \\
\text { Consumed, C } \\
\left(\mathrm{J} \mathrm{g}^{-1} \mathrm{~h}^{-1}\right)\end{array}$ & $\begin{array}{c}\text { Energy } \\
\text { Absorbed, A } \\
\left(\mathrm{J} \mathrm{g}^{-1} \mathrm{~h}^{-1}\right)\end{array}$ & $\begin{array}{c}\text { Energy } \\
\text { Respired, R } \\
\left(\mathrm{J} \mathrm{g}^{-1} \mathrm{~h}^{-1}\right)\end{array}$ & $\begin{array}{c}\text { SFG } \\
\left(\mathrm{J} \mathrm{g}^{-1} \mathrm{~h}^{-1}\right)\end{array}$ \\
\hline Jun 98 & $78.01(41.31)$ & $-9.29(19.66)$ & 6.577 & $-15.87(19.66)$ \\
Jun 98 & $141.61(58.57)$ & $-1.71(31.33)$ & 6.577 & $-8.28(31.33)$ \\
Mar 99 & $60.01(23.95)$ & $2.97(10.29)$ & 6.577 & $-3.61(10.29)$ \\
Mar 99 & $137.38(88.20)$ & $5.36(29.80)$ & 6.577 & $-1.21(29.80)$ \\
Jun 99 & $175.01(56.09)$ & $37.86(22.74)$ & 6.577 & $31.29(22.74)$ \\
Jun 99 & $177.93(56.29)$ & $-27.63(22.58)$ & 6.577 & $-34.21(22.58)$ \\
Feb 00 & $92.34(46.86)$ & $7.93(16.25)$ & 6.577 & $1.35(16.25)$ \\
Feb 00 & $145.22(79.22)$ & $20.47(33.13)$ & 6.577 & $13.89(33.13)$ \\
Sept 00 & $291.23(140.74)$ & $45.72(80.52)$ & 6.577 & $39.14(80.52)$ \\
Sept 00 & $105.93(41.73)$ & $3.27(22.99)$ & 6.577 & $-3.31(22.99)$ \\
\hline
\end{tabular}

Table 5.28. Correlation between SFG and individual seston variables for M. galloprovincialis.

\begin{tabular}{l|ccc}
\hline & $\mathrm{R}^{2}$ & $\mathrm{p}$-value & $n$ \\
\hline TPM & 0.0192 & 0.150 & 109 \\
POM & 0.0521 & 0.017 & 109 \\
PCOM & 0.0001 & 0.905 & 109 \\
Chlorophyll $a$ & 0.0871 & 0.002 & 109 \\
Particle Count & 0.0576 & 0.012 & 109 \\
\hline
\end{tabular}

A backward stepwise multiple regression analysis on all seston variables and dry body weight identified POM, TPM, PCOM, and dry body weight as explaining significant variation in SFG (Table 5.29). The model had an $\mathrm{R}^{2}=0.245$ and gave the following predictive equation:

$$
\text { M. galloprovincialis SFG }=316.72 *(\mathrm{POM})-59.28 *(\mathrm{TPM})-2793.26 *(\mathrm{PCOM})+
$$

$40.15 *$ (Dry weight $)+479.94$

Table 5.29. Regression results on scope for growth for M. galloprovincialis.

\begin{tabular}{l|ccc}
\hline & Coefficient & F-value & p-value \\
\hline Constant & 479.937 & 9.018 & 0.003 \\
Particulate Organic Matter & 316.721 & 17.281 & $<0.001$ \\
Total Particulate Matter & -59.277 & 14.190 & $<0.001$ \\
Percent Organic Matter & -2793.264 & 14.205 & $<0.001$ \\
Dry body weight & 40.148 & 7.851 & 0.006 \\
\hline
\end{tabular}

\subsection{Discussion}

Oxygen consumption rate is usually measured to estimate energy costs of metabolism associated with SFG. Mussels showed a significant correlation of $\mathrm{VO}_{2}$ with dry tissue weight and $\mathrm{VO}_{2}$ values are within the range of published data for similar studies 
(Table 5.5). Variation in oxygen consumption rates with temperature was not particularly pronounced in this study. This is probably due to the relatively small temperature range to which animals were exposed. Studies have shown that mussels show an increase in oxygen uptake with increasing temperature (Widdows, 1973; Thompson, 1984; Marsden \& Weatherhead, 1998). However, SFG is thought to be regulated in intertidal and shallow subtidal mussel species except in temperature extremes, thus SFG is largely independent of temperature within normal limits (Gardner, 2000; fide. Widdows \& Bayne, 1973; Bayne et al., 1973; Widdows, 1978).

Bayne (1973) found evidence of a decrease in oxygen consumption in starved mussels. Bayne (1973) actively deprived mussels of nutrients rather than using natural seawater thought to be nutritionally unsatisfactory. In my study, M. galloprovincialis displayed a decrease in oxygen consumption rate when exposed to ambient Cook Strait water for an extended period. The oxygen consumption rate of $A$. maoriana was depressed slightly and $P$. canaliculus remained about the same. The decrease in oxygen consumption rate is thought to result as a consequence of a decreased metabolic rate of the mussels in order to conserve energy (Bayne, 1973). From these data alone it would appear that M. galloprovincialis is more affected by Cook Strait water than either A. maoriana or $P$. canaliculus. The significant correlations between oxygen consumption rate and dry tissue weight that were seen in initial experiments are not evident in those animals held at IBML $(n=15)$. As with experiments on gonad mass and RNA:DNA ratio, variation in mussels held at IBML was far greater than those from the Harbour. This may in part be due to the lower number of observations of animals held long-term at IBML (P. canaliculus, 6; A. maoriana, 10; $M$. galloprovincialis, 6), although high temperature experiments also had low numbers of mussels and $\mathrm{R}^{2}$ values were high (0.63-0.90). This trend could also be due to different individuals altering their physiological processes at different rates as they undergo stress, in this case probably due to poor quality nutrients.

If Cook Strait water does not contain sufficient nutrients for mussel growth, this should be evident from SFG data from these experiments. This suggestion is only partially supported by these data. The mean SFG in $P$. canaliculus was $45.6 \mathrm{~J} \mathrm{~g}^{-1} \mathrm{~h}^{-1}$. These data were influenced by two incidences when increased levels of POM led to high AE, energy consumption (Tables 5.6 and 5.21) and therefore large SFG values. 
Mean SFG was $19.1 \mathrm{~J} \mathrm{~g}^{-1} \mathrm{~h}^{-1}$ in A. maoriana, and $1.26 \mathrm{~J} \mathrm{~g}^{-1} \mathrm{~h}^{-1}$ for $M$. galloprovincialis. These values, however, are subject to high levels of variation and as such, negative SFG values were numerous; P. canaliculus (27\%), A. maoriana (43\%) and M. galloprovincialis (52\%). In experiments with positive mean SFG, zero values often fell within one SD from the mean (P. canaliculus, 4 of 8; A. maoriana, 6 of 9; M. galloprovincialis, 3 of 4). These data are also slight over-estimates of SFG as the energy loss due to ammonium excretion was not measured. Losses due to ammonium excretion in Mytilus edulis have been recorded in the range of 1.7-2.9\% of the energy loss due to oxygen consumption (Okumu • \& Sterling, 1994). However, Bayne and Widdows (1978) reported higher energy loss in $M$. edulis due to ammonium excretion, and that this varied seasonally depending on spawning activity. During summer spawning energy loss in terms of ammonium excretion was $10-12 \%$ that of oxygen consumption, while in autumn when spawning activity was not evident, energy loss due to ammonium excretion was only $1-2 \%$ of that for oxygen consumption. The contribution of losses due to ammonium excretion is therefore relatively small and would have had little effect on the overall findings.

Data do not suggest a marked division in SFG values between seasons; rather the greatest variation in SFG occurs within each experiment. This was due to high variation in $\mathrm{AE}$ values among individuals within experiments. Coefficients of variation (mean / SD) within each experiment were high for AE data in all species; $P$. canaliculus ranged between 0.15-20.50 with a mean of 2.57, A. maoriana ranged between $0.16-8.78$ with a mean of 0.65 and $M$. galloprovincialis ranged between $0.39-26.77$ with a mean of 4.49 .

Negative SFG is most often the result of insufficient energy acquisition to offset that lost from oxygen consumption and ammonia excretion. In this study, negative SFG was most often the result of negative AE. Mean AE was negative twice in 10 experiments involving $P$. canaliculus, both these experiments are the only occasions when mean SFG was negative. In A. maoriana, six of 15 experiments had negative mean SFG, and on five of these occasions mean AE was also negative. Negative SFG due to a negative net energy balance occurred on only one occasion in A. maoriana. M. galloprovincialis had negative mean AE, and thus negative SFG, in three of 10 experiments, but unlike the other species experienced negative SFG due to net energy 
loss on a further three occasions. High among-individual variation in AE was also noted by Gardner (2000) in three mussel species (P. canaliculus, A. maoriana and M. galloprovincialis) fed on Cook Strait water. When the same species were fed on ambient Wellington Harbour water, much smaller variations in AE were found. Like so many parameters examined in this study, it appears that $\mathrm{AE}$ is also prone to high degrees of variation in mussels held at IBML and fed on ambient Cook Strait water. Gardner and Thompson (2001) examined feeding behaviour in P. canaliculus fed on ambient Cook Strait water and found that AE, and hence SFG estimates, were consistently negative. These experiments were carried out in mid-summer and recorded levels of TPM (3.62-4.12 $\left.\mathrm{mg} \mathrm{l}^{-1}\right)$ and POM (0.82-1.04 $\mathrm{mg} \mathrm{l}^{-1}$ ) that were unusually low when compared to summer seston data in Gardner (2000) and in this study. Using values of summer seston from Gardner and Thompson (2001) in models derived from this experiment also results in consistently negative SFG in all species (Chapter Six). Thus one must be careful not to draw too broad conclusions when looking at data from a narrow time temporal span, especially when they are derived from a dynamic environment such as Cook Strait.

As discussed in Chapter Two, seston quality (chlorophyll $a$, PCOM, \%C, \%N) at IBML is low, not just compared to Harbour sites, but also to published studies of bivalve feeding physiology in temperate waters. It has been shown that many mussel species can alter their feeding behaviour in order to compensate for low quality seston (see Introduction). It has been documented that poor seston quality can lead to negative AE when PCOM drops to approximately 20\% in Mytilus edulis (Bayne et al., 1987). This positive relationship between seston quality and AE is well documented in mussels (Hawkins et al., 1996; Wong \& Cheung, 1999; Bricelj \& Malouf, 1984; Bayne et al., 1987; Navarro et al., 1991), particularly for PCOM (Griffiths, 1980; Bayne et al., 1987). This relationship has also been demonstrated by a decrease in AE with increased seston ash content (Hawkins et al., 1996; Bayne et al., 1987, 1988). Bayne et al. (1987) and Hawkins et al. (1990) found that AE was related to organic content of the diet and increased with increased gut passage time. Gut passage time, however, was not measured in these experiments. Bayne and Hawkins (1990) suggest variation in $\mathrm{AE}$ values can be within the range of $-60 \%$ to $+60 \%$. Under natural seston conditions however, this range is more likely to be +20 to $+60 \%$ (Bayne et al., 1984). AE values were negative for many of the individuals within these experiments, 
P. canaliculus (21\%), A. maoriana (35\%) and M. galloprovincialis (41\%). Data from IBML show mean AE (summer, winter, spring) of 12, 21, and $17 \%$ for P. canaliculus, $-16.7,-6.4^{2}$ and $-2.9 \%$ for A. maoriana, and $4.95,-17.7$ and $13.35 \%$ for $M$. galloprovincialis. These values are similar to those reported by Gardner (2000) for mussels fed on Cook Strait water. The greatest difference is seen for A. maoriana during winter: Gardner (2000) reported a mean AE of $34 \%$ compared to $-18 \%$ in this study. Negative AE will necessarily result in negative SFG as animals are losing more organic material than they are gaining. Negative AE values are a result of epithelial cells, enzymes and other substances being secreted into the gut but not reabsorbed, and hence more organic material is secreted than assimilated. Such losses are termed metabolic faecal loss (MFL) (Bayne \& Hawkins, 1990; Hawkins \& Bayne, 1992). Losses in mussels are considerably higher than those experienced by other invertebrates (Hawkins \& Bayne, 1992) and are in part due to the nature of mussel digestion. Mussels utilise intracellular digestion, that is, the rejection of cell contents into a vacuole where digestion takes place. This is an additional cost which is likely to contribute to high MFL (Bayne et al. 1988; Hawkins \& Bayne, 1992). Bayne et al. (1988) suggest that MFL has a particularly noticeable effect on AE when the diet is of low organic content. This contention would be supported for each of the three species in experiments at IBML.

Hawkins et al. (1999) investigated the ecophysiological response of P. canaliculus to a wide range of seston characteristics. They found that pseudofaecal material was produced at all but the very lowest seston concentrations. In my study pseudofaecal material was produced approximately $50 \%$ of the time in all species (Chapter Six, Table 6.1). Hawkins et al. (1999) found that $P$. canaliculus regulated feeding responses over a very broad range of seston regimes. Variation in CR rate was the primary source of regulation of feeding. CR rate responded most closely to chlorophyll $a$ and increased to a maximum at concentrations of between 1 and $2 \mu \mathrm{g}$ chl $a \mathrm{l}^{-1}$ after which it declined at higher concentrations. After the maximum, CR also reduced exponentially with increasing TPM. Regardless of the reduction in CR with increasing TPM, both filtration rate and ingestion rate continued to increase with increasing TPM up to extreme concentrations of $1000 \mathrm{mg} \mathrm{l}^{-1}$. Hawkins et al. (1999) go on to note that when analysing the feeding responses of mussels to seston, care must

\footnotetext{
${ }^{2}$ This value excludes the southerly storm event
} 
be taken to ensure that mussels are actually responding to the variable being measured and not to some other seston characteristic which is not being evaluated. Hawkins et al. (1999) found that organic enrichment was primarily affected by the retention of particles that were rich in chlorophyll as opposed to non-living plant organics. Hawkins et al. (1999) found that tissue wasting occurred when P. canaliculus of $1 \mathrm{~g}$ dry tissue weight was fed on seston with chlorophyll $a$ concentrations of less than $0.86 \pm 0.19 \mu \mathrm{g} \mathrm{l}^{-1}$. Water sampling data from Coastal sites (Chapter Two) were rarely above $0.5 \mu \mathrm{g} \mathrm{l}^{-1}$ suggesting tissue wastage and inevitable death. At Harbour sites however, while chlorophyll $a$ values were on average considerably higher than at

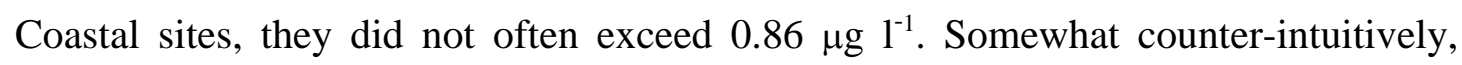
Hawkins et al. (1999) reported that the increased filtration rate resulted in increased efficiency with which organic particles were retained on the ctenidia, allowing for the rejection of inorganic particles as pseudofaces prior to ingestion. This resulted in an increase in the organic content of ingested material of up to seven times that of the seston. Hawkins et al. (1999) state that "Perna canaliculus regulated rates of organic absorption and growth independent of ranges of seston availability and composition wider than have hitherto been observed in any bivalve” (p. 226). Given the findings of Hawkins et al. (1999) and the above quoted assertion, it may not be surprising that $P$. canaliculus experienced greater SFG than the other species.

The literature contains many papers dealing with the feeding behaviour of bivalves when exposed to different seston regimes. However, relatively few studies exist that use SFG under ambient seston conditions to assess the suitability of an environment to support mussel populations. Anderlini (1992) measured the scope for growth of $P$. canaliculus and Mytilus edulis aoteanus (M. galloprovincialis) when exposed to effluent from a sewer outfall at a variety of sites on the eastern side of the Wellington Harbour entrance. Anderlini (1992) concluded that heavy metals associated with the outfall caused a decrease in SFG. Unfortunately, these data cannot to be compared to those from my study as filtered sea water with an algal monoculture of Isochrysis galbana was used as a food source. As previously mentioned, mussels have been shown to respond differently such diets compared to natural seawater (Navarro et al., 1992; Hawkins et al., 1996; Hawkins et al., 1999). Page and Ricard (1990) reported that mussel growth at two Californian coastal sites was limited by food availability although both sites had different seston characteristics. Seston concentration limited 
growth at Holly, an offshore (3 km) platform where seston had low TPM (1-5 mg l-1) and POM (<0.5 $\mathrm{mg} \mathrm{l}^{-1}$ ) but high PCOM 40-70\%. At Avila, a coastal embayment, composition rather than concentration affected growth. This site was characterised by high TPM (10-30 $\mathrm{mg} \mathrm{l}^{-1}$ ) and POM (1-5 mg l-1, up to 10) and low PCOM (10-35\%). Okumu • and Sterling (1994) compared the SFG of Mytilus edulis from two Scottish lochs, Loch Etive and Loch Leven. Higher food quality (POM and PCOM) and better feeding conditions in Loch Etive resulted in significantly higher SFG than in Loch Leven. Gardner (2000) suggested that food limitation was a factor contributing to the absence of mussels on Wellington's South Coast. He found that at Island Bay $P$. canaliculus, A. maoriana and M. galloprovincialis all experienced negative SFG in the summer, whilst in winter only M. galloprovincialis had negative SFG. In order that $P$. canaliculus and A. maoriana cannot survive on Cook Strait shores, the energy stored over the winter when SFG is positive must be less than that required for the duration of the summer period when SFG is negative. Bayne and Widdows (1978) found that a population of $M$. edulis was capable of surviving on stored energy reserves despite negative SFG over 4-5 months. Gardner (2000) also noted that no pseudofaecal production occurred in any of the three species studied at Island Bay. In the present study, pseudofaecal production was noted in all three species $\approx 50 \%$ of the time (Table 6.1). This may be due to different seston characteristics between years, hence contributing to the different results obtained for SFG estimates, although a comparison between studies does not show vast differences between the seston in these experiments. As mentioned in the introduction to this chapter, it is necessary to conduct feeding experiments using natural seston rather than algal monocultures. Recent studies (Hawkins et al., 1996: Hawkins et al., 1999: Gardner, 2001) have shown that mussels are capable of altering their feeding behaviour significantly in response to seston conditions. Much of this behaviour stems from the mussels' ability to preferentially select food items, an ability that is lost when exposed to monocultured alga.

In summary, these data only partially support the hypothesis that low food quality is a factor contributing to mussel absence on Wellington's South Coast. While SFG estimates are often negative in all species, and are subject to large variation, the mean SFG in all species is positive. The frequency with which negative AE was recorded 
indicates that MFL is responsible for the majority of negative SFG estimates as opposed to negative net energy balance.

Further investigation of SFG in all three species over a broader range of seston conditions would help to ascertain the influence of seston quality on the mussel distribution in the Wellington region. For example, Gardner and Thompson (2001) clearly demonstrated negative SFG in P. canaliculus during summer at IBML when seston quality was relatively low. However, SFG estimates reported in the present study indicate $P$. canaliculus is capable of positive SFG when seston quality is higher. Bayne and Widdows (1978) studied a population of M. edulis that had negative SFG for 4-5 months; during this time mussels relied on stored energy reserves to survive. Studies of mussel condition in Chapter Four confirmed that mussels were losing condition at IBML compared to those within the Harbour. If mussels are unable to store sufficient reserves during times of relatively high seston quality, they may not have the energy reserves to survive periods of lower seston quality. Closer investigation of mussel energy reserves and the capacity of mussels to store energy when feeding on Coastal water may provide further insight into mussel absence from Coastal shores. Future studies might also be conducted to assess the causes of high variation of AE and the associated incidence of negative SFG due to MFL. 


\section{CHAPTER SIX}

\section{Bioenergetic Modelling}

\subsection{Introduction}

A great deal of work in recent years has gone into the study of the various components of bivalve feeding physiology. Much of this accumulated knowledge has recently been incorporated into models to predict scope for growth (SFG) and bivalve growth rate (Schneider, 1992; Grant, 1996; Grant \& Bacher, 1998; Hawkins et al., 1999; Newell et al., 1998; Campbell \& Newell, 1998; Frechette \& Bacher, 1998; Schloten \& Smaal, 1998; Pouvreau et al., 2000). It is hoped that such models will eventually be available to predict the suitability and carrying capacity of waters used in marine farming, as well as to assess the changes to the environment caused by marine farms. Such models will also aid in the understanding of large scale ecological systems, and help solve problems such as the one addressed in this study. Unfortunately, these models often lack broad applicability for a number of reasons. Firstly, the nature of bivalve feeding is complex and not completely understood. Also not fully understood are the species-specific responses of feeding behaviour to changes in the quantity and quality of the seston. This is particularly important in an organism that is exposed to daily and seasonal fluctuations in feeding material (Grant \& Bacher, 1998). In addition to this, models are often not applicable across different regions and species, even those closely related. Pouvreau et al., (2000) concluded that their model was only validated at Takapoto atoll because of temperature effects and the range of food concentration. In addition to this, species have shown varied responses when exposed to the same experimental diets (van Erkom Schrink \& Griffiths, 1992; Hawkins et al., 1990; Gardner, 2000; Gardner, 2001). An additional complication is that many older studies have relied on diets of algal-monoculture which have recently been shown to induce very different responses to those mussels fed on ambient diets (Hawkins et al., 1996; Hawkins et al., 1999).

Models have been formulated to answer ecological questions, as well as those relating to the farming of various bivalve species. Schneider (1992) used a bioenergetic model 
to estimate the growth rate and consumption of the zebra mussel, Dreissena polymorpha in the Laurentian Great Lakes. The zebra mussel was introduced into the Great Lakes in 1988 and in some lakes has reached very high densities. The potential population growth rate is not known, nor is it known in which lakes the mussels will reach nuisance levels. The effects of the zebra mussel on food web dynamics and sedimentation are also questions that are being answered using such models (Schneider, 1992). In an example of modelling for aquacultural purposes, Pouvreau et al. (2000) used a bioenergetic model to provide farm managers with information for improving the cultivation of the black pearl oyster, Pinctada margartifera. These data were able to provide farm managers with information on when to produce a pearl, spat collection, density in system culture, choice of farming site and carrying capacity. Modelling by Hawkins et al. (1999) demonstrated that $P$. canaliculus had the ability to maintain maximal growth rates over a very wide range of seston conditions. They concluded that this may offer the opportunity to culture $P$. canaliculus in turbid, less traditional sites, thus offering more stable optimal nutrition and relieving the pressures of overstocking (Hawkins et al., 1999).

Gardner (2000) and Gardner and Thompson (2001) suggested that food limitation was likely to be primarily responsible for the absence of mussels from Cook Strait shores. However, the data presented in Chapter Five only partially support this assertion. More detailed experimental studies of the feeding responses of mussels to a greater number of seston characteristics (e.g. chlorophyll $a$, absolute $\mathrm{C}$ and N, C:N, TPM, POM, PCOM) and continued measurements of these data from field sites should provide a more conclusive answer. Modelling SFG of each mussel species at a number of sites both inside and outside the Harbour may also help to establish the influence of food limitation on mussel distribution on Wellington's South Coast.

From the feeding experiments documented in Chapter Five, equations to predict SFG can be generated based on seston characteristics that explain the greatest variation in SFG. Data from water samples collected at the eight sites documented in Chapter Two can be substituted into these equations to predict species-specific SFG at each of the eight sites under different seston regimes. This will indicate to what degree each 
mussel species is capable of existing at each of the eight locations at different times of the year.

\subsection{Materials and Methods}

Two models were used to predict SFG for P. canaliculus, A. maoriana and $M$. galloprovincialis at each of eight sites inside and outside Wellington Harbour. Model One was derived from data gathered in feeding experiments outlined in Chapter Five. New regression models were used for this analysis because those generated in Chapter Five contained parameters that could not be used with seston data in Chapter Two. The M. galloprovincialis regression equation included dry tissue mass, which is not applicable in a general seston model, and $P$. canaliculus and A. maoriana included particle count. Data for particle count were not available at all water sampling dates due to the breakdown of the particle counter. Model Two uses data derived from feeding experiments conducted by Gardner (2002) for P. canaliculus, A. maoriana and M. galloprovincialis. Seston data presented in Chapter Two will be substituted into these equations to predict SFG at each of eight sites on 21 occasions between September 1998 and February 2000.

\section{Model One}

SFG and seston data from Chapter Five were used to conduct a separate backward step-wise regression analysis (critical $\alpha=0.015$ ) for each species using the following model:

$$
\mathrm{SFG}=\mathrm{TPM}+\mathrm{POM}+\mathrm{PCOM}+\text { chlorophyll } a
$$

The regression analyses showed that seston explained significant variation in SFG for all three species $(\mathrm{p}<0.001)$; the $\mathrm{R}^{2}$ values and predictive equations are as follows ${ }^{3}$ :

P. canaliculus $\left(\mathrm{R}^{2}=0.707\right): \mathrm{SFG}=467.94 * \mathrm{POM}-100.55 * \mathrm{TPM}-4988.79 * \mathrm{PCOM}+1107.68$

A. Maoriana $\left(\mathrm{R}^{2}=0.416\right): \mathrm{SFG}=3.43 * \mathrm{TPM}+400.72 * \mathrm{PCOM}-140.47$

M. galloprovincialis $\left(\mathrm{R}^{2}=0.188\right): \mathrm{SFG}=349.16 * \mathrm{POM}-65.77 * \mathrm{TPM}-3147.88 * \mathrm{PCOM}$

$$
+575.99
$$

\footnotetext{
${ }^{3}$ TPM and POM data are in milligrams per litre, PCOM expressed as proportion.
} 
The range of seston characteristics from which these models are derived is very restricted for $P$. canaliculus and $M$. galloprovincialis, whereas A. maoriana was exposed to a greater range on seston in feeding experiments at IBML (Table 6.1). The possible implications of this will be addressed below. Seston data collected from the eight sites described in Chapter Two were substituted into each of the equations to estimate SFG at each site over the period from September 1998 to February 2000.

Table 6.1. Seston conditions in feeding experiments at IBML from Chapter Five for each species (mean \pm SD), and those from Gardner (2000) from which Model Two was constructed.

\begin{tabular}{l|cccc}
\hline & $\begin{array}{c}\text { POM } \\
\left(\mathrm{mg} \mathrm{l}^{-1}\right)\end{array}$ & $\begin{array}{c}\text { TPM } \\
\left(\mathrm{mg} \mathrm{l}^{-1}\right)\end{array}$ & PCOM & Chl $a\left(\mu g ~^{-1}\right)$ \\
\hline P. canaliculus & $2.80( \pm 0.93)$ & $12.32( \pm 2.62)$ & $0.229( \pm 0.053)$ & $0.034( \pm 0.015)$ \\
A. maoriana & $4.45( \pm 2.76)$ & $18.00( \pm 9.62)$ & $0.245( \pm 0.063)$ & $0.048( \pm 0.031)$ \\
M. galloprovincialis & $2.54( \pm 0.29)$ & $11.49( \pm 1.77)$ & $0.224( \pm 0.034)$ & $0.032( \pm 0.039)$ \\
\hline
\end{tabular}

Table 6.2. Seston conditions in feeding experiments at IBML and Kau Bay (mean \pm SD, n) from Gardner (2000) from which Model Two was constructed.

\begin{tabular}{l|llc}
\hline & POM $\left(\mathrm{mg} \mathrm{l}^{-1}\right)$ & \multicolumn{1}{|c}{ TPM $\left(\mathrm{mg} \mathrm{l}^{-1}\right)$} & PCOM \\
\hline Island Bay Summer & $2.8 \pm 0.9(30)$ & $9.3 \pm 3.0(30)$ & $30.07 \pm 2.31(30)$ \\
Island Bay Winter & $3.0 \pm 0.7(15)$ & $14.0 \pm 2.4(15)$ & $21.45 \pm 2.66(15)$ \\
Kau Bay Summer & $4.0 \pm 1.1(30)$ & $13.7 \pm 3.5(30)$ & $28.92 \pm 15.1(30)$ \\
Kau Bay Winter & $7.0 \pm 1.1(15)$ & $11.8 \pm 1.3(15)$ & $59.17 \pm 6.44(15)$ \\
\hline
\end{tabular}

\section{Model Two}

The above models, derived from the feeding experiments in Chapter Five, were calculated from a small range of seston concentrations at IBML. It was thought that such a narrow range of seston characteristics could cause the models to inaccurately estimate SFG when applied to higher seston concentrations in Wellington Harbour. A second group of models was therefore used to estimate SFG in each species. These models were derived from work carried out at IBML and Kau Bay, Wellington Harbour (Gardner, 2001) and are constructed from a wider range of seston concentrations (Table 6.2). The models estimate $\mathrm{CR}_{\mathrm{s}}$ and AE, but not SFG. SFG was therefore calculated from these parameters and from the respiration $\left(\mathrm{VO}_{2}\right)$ data from Chapter Five as follows: 


$$
\mathrm{SFG}=\left(\mathrm{CR}_{\mathrm{s}}\left(\mathrm{lg}^{-1} \mathrm{~h}^{-1}\right)\right) *\left(\text { Seston POM }\left(\mathrm{mg} \mathrm{l}^{-1}\right) * 23 \mathrm{~J}\right) * \mathrm{AE}-\mathrm{VO}_{2}\left(\mathrm{~J} \mathrm{~g}^{-1} \mathrm{~h}^{-1}\right)
$$

These models did not account for potential enrichment of ingested ration by pseudofaecal production; therefore enrichment had to be estimated from feeding experiments at IBML and incorporated into the model. This was done by estimating the pseudofaecal threshold of mussels at IBML and applying a correction to those seston data over the threshold. The correction was estimated by calculating filtration rate (FR (mg h$\left.\left.{ }^{-1}\right)=\mathrm{CR}_{\mathrm{s}} * \mathrm{TPM}\right)$ and the proportion of filtered ration lost (loss) due to pseudofaecal (PSF) production (loss $=$ PSF $\left(\mathrm{mg} \mathrm{h}^{-1}\right) / \mathrm{FR}\left(\mathrm{mg} \mathrm{h}^{-1}\right)$ ). This represented the pre-ingested ration $\left(\mathrm{PIR}=\mathrm{FR}^{*}(1-\mathrm{loss})\right)$. Enrichment $(\mathrm{E})$ of pre-ingested ration was calculated as ( $\mathrm{E}=\mathrm{PCOM}$ of seston / PCOM of PSF). This coefficient of enrichment was applied to the pre-ingested ration (PIR) to calculate the ingested ration (IR) of the organic and inorganic material (IR = PIR*E).

The example below shows that the ration filtered is enriched by $11 \%$ ( 27.8 / 25) due to PSF production (Table 6.3). Although FR is voided, it contains less organic material, ultimately enriching the ingested seston.

Assuming: $\mathrm{CR}_{\mathrm{s}}=2.5 \mathrm{lg}^{-1} \mathrm{~h}^{-1}$

$\mathrm{TPM}=10 \mathrm{mg} \mathrm{l}^{-1}$

Pseudofaecal production rate $=5 \mathrm{mg} \mathrm{h}^{-1}$

Seston PCOM $=0.25$

PSF PCOM $=0.18$

Table 6.3. Hypothetical example of enrichment of ingested seston by pseudofaecal production.

\begin{tabular}{|c|c|c|c|c|}
\hline FR & \% Loss & PIR & E & IR \\
\hline $\mathrm{CR}_{\mathrm{s}} *$ TPM & PSF / FR & FR * (1- \% loss) & PCOM seston / PCOM PSF & PIR * E \\
& & & & \\
$2.5 * 10=25$ & $5 / 25=0.2$ & $25 * 0.8=20$ & $25 / 18=1.39$ & $20 * 1.39=27.8$ \\
\hline
\end{tabular}

The equations from Gardner (2002) are as follows ${ }^{4}$ :

\footnotetext{
${ }^{4}$ TPM and POM data are in grams per litre, PCOM expressed as percent.
} 
P. canaliculus $\left(\mathrm{R}^{2}=0.192\right): \mathrm{CR}_{\mathrm{s}}=0.33 * \mathrm{POM}+2.07$

A. maoriana $\left(\mathrm{R}^{2}=0.156\right): \mathrm{CR}_{\mathrm{s}}=0.05 * \mathrm{PCOM}+1.01$

M. galloprovincialis $\left(\mathrm{R}^{2}=0.185\right): \mathrm{CR}_{\mathrm{s}}=0.07 * \mathrm{PCOM}+1.63$

P. canaliculus $\left(\mathrm{R}^{2}=0.517\right): \mathrm{AE}=22.91 * \mathrm{TPM}+0.01 * \mathrm{PCOM}-0.05$

A. maoriana $\left(\mathrm{R}^{2}=0.593\right)$ : $\mathrm{AE}=92.84 * \mathrm{TPM}-276.52 * \mathrm{POM}+0.043 * \mathrm{PCOM}-1.21$

M. galloprovincialis $\left(\mathrm{R}^{2}=0.560\right): \mathrm{AE}=66.73 * \mathrm{POM}+0.008 * \mathrm{PCOM}-0.36$

\section{Validation of models}

To validate the SFG estimates derived from both models, seston data from the feeding experiments in Chapter Five were fitted to both models to predict SFG. The SFG estimates from the two models were compared to the actual SFG estimates from the experiments. This will give an indication of how well each model is predicting SFG and also allow for comparison between the two models.

\subsection{Results}

The data from feeding experiments at IBML suggested a pseudofaecal threshold of $12.5 \mathrm{mg} \mathrm{l}^{-1}$ TPM for $P$. canaliculus and A. maoriana, and $12.0 \mathrm{mg}^{-1} \mathrm{TPM}$ for $M$. galloprovincialis. Pseudofaecal material was produced approximately $50 \%$ of the time in $P$. canaliculus and A. maoriana, with $M$. galloprovincialis producing pseudofaeces less frequently (Table 6.4). The proportion of filtered ration rejected as pseudofaecal material was greatest in M. galloprovincialis (36\%), followed by A. maoriana (20\%) and P. canaliculus (10\%) (Table 6.4). Ingested material was enriched by all species through pseudofaecal production, enrichment of the ingested ration (PCOM of seston / PCOM of pseudofaeces) was highest in A. maoriana (43\%), followed by $P$. canaliculus (33\%) and M. galloprovincialis (24\%). The net result was an increase in organic content of ingested ration in P. canaliculus (19\%) and A. maoriana (15\%), while M. galloprovincialis experienced a net decrease (Table 6.4). 
Table 6.4. Summary of pseudofaecal production from feeding experiments at IBML.

\begin{tabular}{l|ccccc}
\hline & $\begin{array}{c}\text { PSF } \\
\text { threshold } \\
\left(\mathrm{mg} \mathrm{l}^{-1} \text { TPM) }\right.\end{array}$ & $\begin{array}{c}\text { Frequency } \\
\text { of PSF } \\
\text { production } \\
(\%)\end{array}$ & $\begin{array}{c}\text { Filtered } \\
\text { ration } \\
\text { discarded } \\
\text { as PSF (\%) }\end{array}$ & $\begin{array}{c}\text { Enrichment of } \\
\text { Ingested ration } \\
(\%)\end{array}$ & $\begin{array}{c}\text { Compensation } \\
\text { due to PSF } \\
\text { production }\end{array}$ \\
\hline P. canaliculus & 12.5 & 50.4 & 10.3 & 32.4 & 1.19 \\
A. maoriana & 12.5 & 49.7 & 19.6 & 43.4 & 1.15 \\
M. galloprovincialis & 12.0 & 39.4 & 35.8 & 23.6 & 0.81 \\
\hline
\end{tabular}

\subsubsection{SFG estimates derived from Model One}

\section{P. canaliculus}

SFG estimates for $P$. canaliculus were predominantly positive. Of the 159 seston observations used in Model One, only 23 (14.5\%) showed negative SFG values (Table 6.5). The negative SFG values are spread evenly across sites and are not confined to the Coast, although there was a trend towards higher mean $( \pm S D)$ SFG values at Harbour (81.4 \pm 141.7) sites and lower SFG values at Coastal sites (39.1 \pm 63.8) (Fig. 6.1). Temporal variation within each site did not show long periods of negative SFG at Coastal or Harbour sites (Fig. 6.2).

Table 6.5. Model One: Predicted SFG for P. canaliculus.

\begin{tabular}{|c|c|c|c|c|c|c|c|c|}
\hline Date & 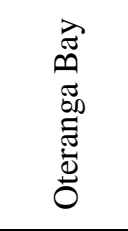 & $\begin{array}{l}\vec{\nexists} \\
\oplus \\
\stackrel{\Xi}{\Xi} \\
\frac{\vec{\omega}}{\omega}\end{array}$ & 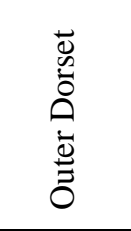 & 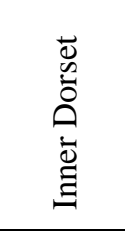 & $\begin{array}{l}\vec{\Xi} \\
\oplus \\
\vec{\Xi} \\
\vec{E}\end{array}$ & 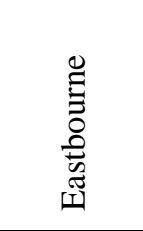 & 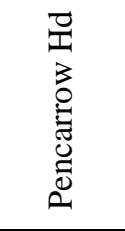 & 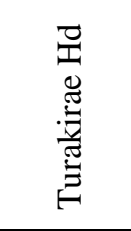 \\
\hline Sep-98 & 52.16 & 38.01 & 42.23 & 85.33 & 97.06 & 202.68 & 56.27 & 75.09 \\
\hline Sep-98 & & 74.71 & 132.38 & 70.19 & 95.94 & 134.52 & 106.25 & \\
\hline Oct-98 & 52.91 & -178.92 & 137.68 & 120.36 & 87.93 & 117.07 & 85.16 & -90.14 \\
\hline Nov-98 & 145.90 & 84.80 & 85.68 & 98.06 & 95.36 & 96.97 & 95.95 & 58.80 \\
\hline Nov-98 & 98.64 & 81.43 & 102.77 & 125.08 & 116.09 & 1058.33 & 107.00 & 112.62 \\
\hline Dec-98 & 39.68 & 56.14 & & & & & & \\
\hline Jan-99 & 29.86 & 37.09 & 28.69 & 42.83 & 40.33 & 27.89 & 25.06 & 22.64 \\
\hline Feb-99 & 35.22 & -58.04 & -99.00 & 113.12 & 118.71 & 89.21 & -72.53 & 66.67 \\
\hline Mar-99 & 80.79 & 82.35 & 71.15 & 162.82 & 129.56 & 154.17 & 114.37 & 69.01 \\
\hline Mar-99 & 30.55 & 23.79 & 31.33 & 14.23 & 33.00 & 47.03 & 36.95 & 31.37 \\
\hline Apr-99 & 28.40 & 63.23 & 40.92 & 64.72 & 50.39 & 52.78 & 72.63 & 50.92 \\
\hline Apr-99 & 36.14 & 27.82 & 42.37 & 69.09 & 87.19 & -13.88 & 39.94 & 34.42 \\
\hline May-99 & -43.46 & 2.17 & -11.72 & 23.02 & 49.90 & 24.33 & -44.58 & 18.18 \\
\hline Jun-99 & 47.71 & 44.72 & 98.29 & -45.12 & 33.21 & 30.83 & -2.59 & 6.07 \\
\hline Jul-99 & -60.78 & -67.58 & 2.01 & -26.62 & 13.53 & 12.79 & -71.75 & 29.11 \\
\hline Aug-99 & 40.08 & 91.42 & 51.58 & 66.64 & 110.91 & 77.95 & 65.73 & 47.47 \\
\hline Sep-99 & 54.57 & 165.79 & 97.78 & 88.04 & 155.83 & 162.68 & 221.51 & 200.15 \\
\hline Oct-99 & 31.80 & 32.31 & 41.91 & 49.62 & 61.09 & 120.63 & 26.67 & 19.47 \\
\hline Nov-99 & -47.58 & 1.94 & -25.62 & -58.47 & -51.28 & -121.23 & -49.18 & -167.14 \\
\hline Dec-99 & 18.33 & 37.44 & 25.80 & -11.37 & 20.40 & 26.62 & 46.45 & 4.05 \\
\hline Jan-00 & 18.17 & 51.63 & 76.34 & 77.91 & 85.64 & 20.32 & 66.44 & \\
\hline Mean & 34.45 & 32.97 & 48.63 & 56.47 & 71.54 & 116.08 & 46.29 & 32.71 \\
\hline SD & 47.27 & 69.85 & 56.17 & 58.95 & 48.54 & 233.41 & 71.43 & 75.53 \\
\hline
\end{tabular}




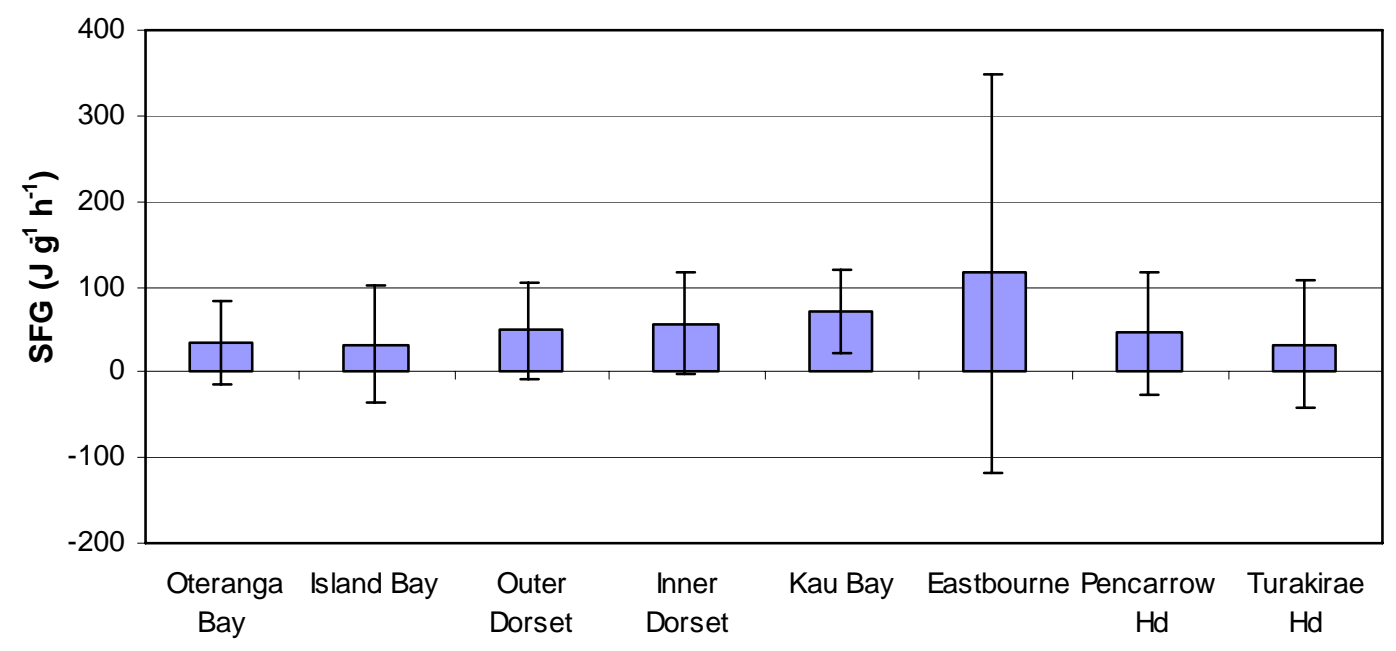

Figure 6.1. Model One: Mean estimated SFG for $P$. canaliculus.
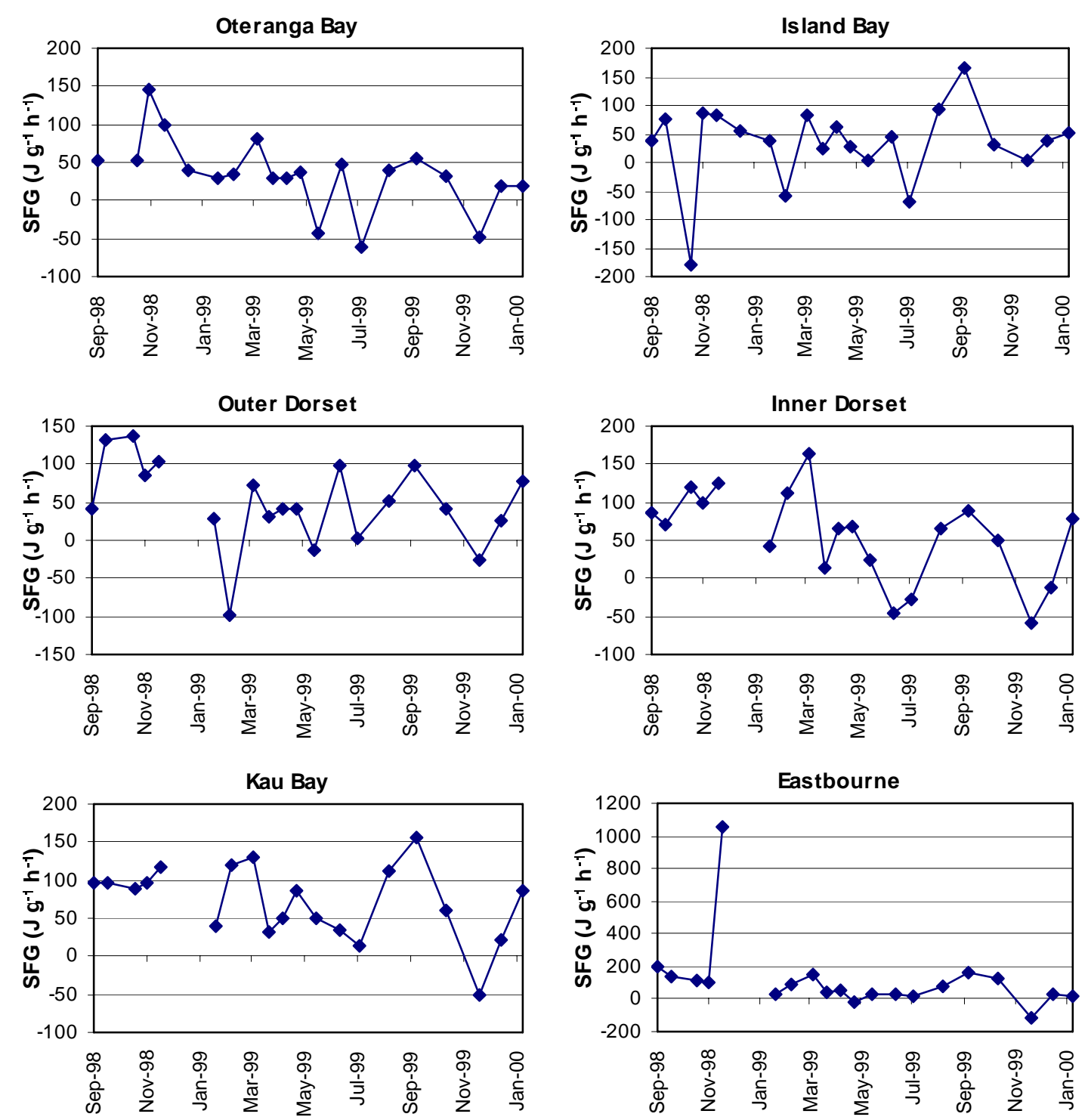

Figure 6.2. (Continued over page) Model One: Temporal variation in estimated SFG at all sites for $P$. canaliculus. 

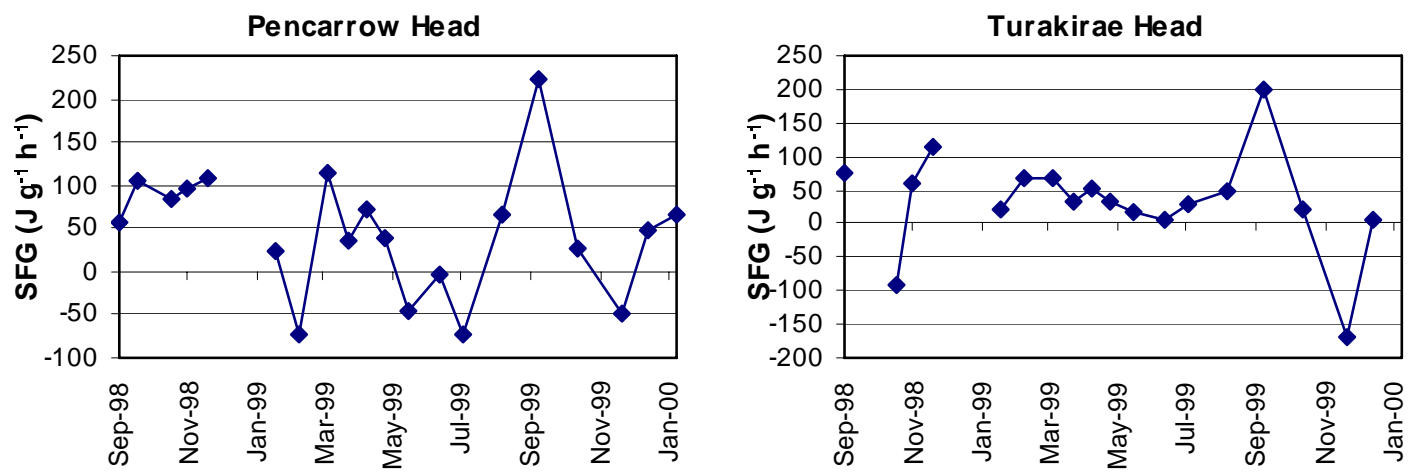

Figure 6.2. (Continued from above) Model One: Temporal variation in estimated SFG at all sites for $P$. canaliculus.

\section{A. maoriana}

SFG estimates derived from Model One for A. maoriana were lower than those estimated for $P$. canaliculus. Of the 159 observations for A. maoriana, 83 (52.2\%) were negative (Appendix C). The greatest proportion of negative SFG values was seen at Coastal sites, and mean SFG was lower at Coastal $(-6.32 \pm 18.28)$ sites compared to Harbour sites (1.44 \pm 23.92$)$ (Table 6.6 \& Fig. 6.3).

Table 6.6. Model One: Predicted SFG for A. maoriana.

\begin{tabular}{|c|c|c|c|c|c|c|c|c|}
\hline Date & 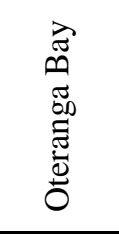 & 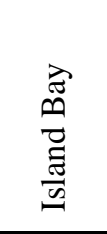 & 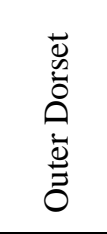 & 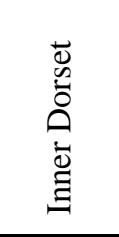 & $\begin{array}{l}\vec{\nexists} \\
\oplus \\
\vec{\nabla} \\
\vec{\nabla}\end{array}$ & 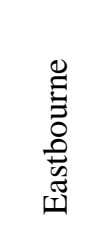 & 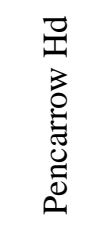 & 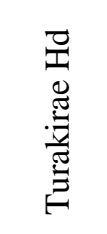 \\
\hline Sep-98 & -3.69 & $\begin{array}{l}-15.33 \\
\end{array}$ & -8.43 & 10.92 & 12.06 & 34.72 & 5.30 & 24.47 \\
\hline Sep-98 & & 11.34 & 16.30 & 3.04 & 9.04 & 16.96 & 9.29 & \\
\hline Oct-98 & 10.46 & 18.28 & 17.39 & 13.84 & 7.12 & 12.94 & 15.99 & -9.98 \\
\hline Nov-98 & 18.21 & 6.02 & 11.90 & 14.62 & 16.58 & 12.99 & 14.95 & -0.82 \\
\hline Nov-98 & 12.03 & 5.85 & 10.05 & 16.31 & 16.12 & 85.66 & 12.25 & 12.73 \\
\hline Dec-98 & -10.02 & -2.76 & & & & & & \\
\hline Jan-99 & -19.44 & -38.16 & -15.18 & -10.71 & -11.81 & -19.00 & -19.71 & -34.47 \\
\hline Feb-99 & -19.67 & 2.53 & 6.46 & 12.65 & 20.53 & 14.07 & -5.41 & 10.96 \\
\hline Mar-99 & 9.58 & 16.14 & 21.77 & 37.64 & 28.15 & 30.95 & 22.10 & 4.00 \\
\hline Mar-99 & -23.42 & -23.01 & -17.11 & -16.75 & -15.59 & -6.11 & -13.41 & -17.23 \\
\hline Apr-99 & -14.11 & 5.95 & -10.08 & 17.63 & 4.52 & 7.72 & 6.42 & 2.70 \\
\hline Apr-99 & -13.08 & -7.43 & -8.88 & 2.93 & 18.66 & 9.71 & -10.37 & -16.67 \\
\hline May-99 & -27.60 & -17.77 & -10.96 & -21.09 & -3.48 & -23.32 & -19.43 & -23.93 \\
\hline Jun-99 & -0.97 & -5.04 & 13.34 & -16.80 & -19.48 & -19.00 & -13.93 & -18.52 \\
\hline Jul-99 & -33.24 & -40.87 & -34.78 & -33.62 & -34.65 & -27.47 & -35.99 & -26.13 \\
\hline Aug-99 & -4.10 & 12.22 & -0.36 & 1.22 & 13.91 & 8.26 & 2.80 & -8.75 \\
\hline Sep-99 & -3.28 & 17.45 & 3.27 & 6.52 & 23.99 & 25.73 & 33.08 & 30.90 \\
\hline Oct-99 & -10.49 & -10.94 & -8.59 & -1.04 & 0.27 & 29.86 & -13.12 & -18.91 \\
\hline Nov-99 & -32.29 & -41.92 & -40.06 & -50.86 & -51.60 & -44.90 & -58.48 & -49.76 \\
\hline Dec-99 & -14.89 & -11.63 & -14.17 & -28.99 & -19.85 & -23.73 & -5.02 & -28.26 \\
\hline Jan-00 & -12.60 & -7.18 & 3.01 & 3.53 & 6.75 & -21.67 & -1.09 & \\
\hline Mean & -9.63 & -6.01 & -3.26 & -1.95 & 1.06 & 5.22 & -3.69 & -9.31 \\
\hline SD & 14.60 & 18.56 & 16.70 & 20.97 & 20.80 & 29.61 & 20.89 & 20.96 \\
\hline
\end{tabular}




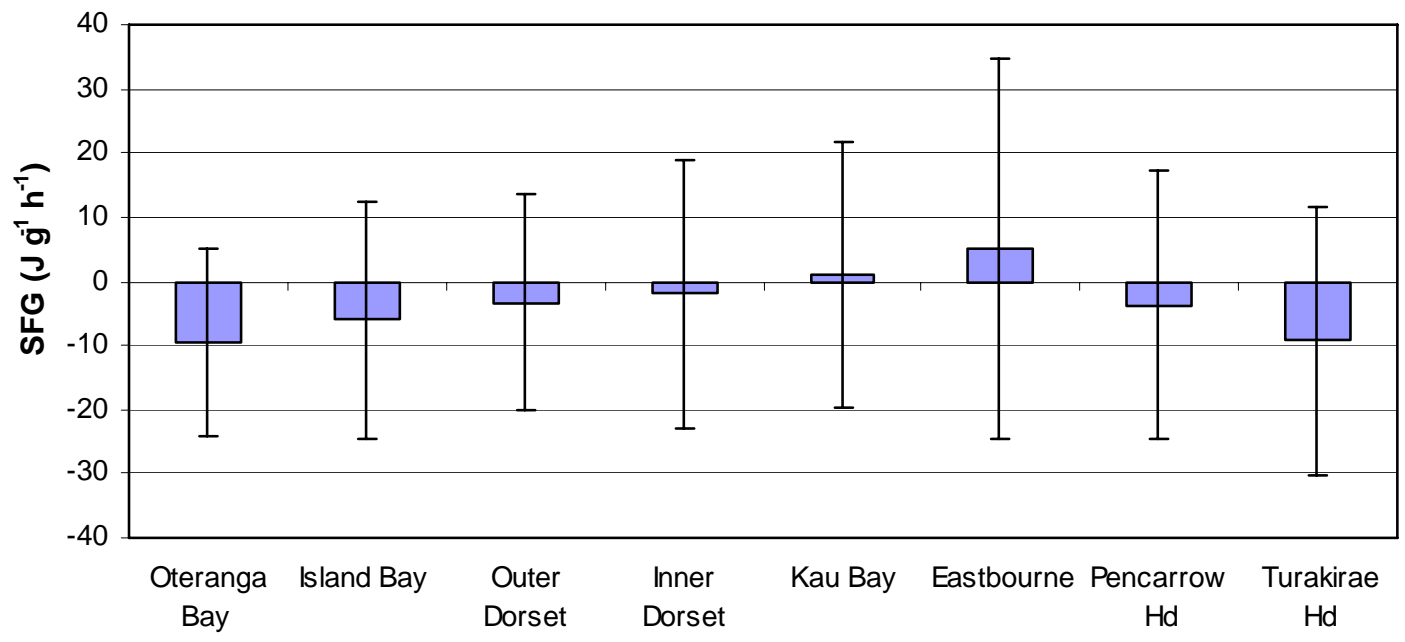

Figure 6.3. Model One: Mean estimated SFG for A. maoriana.

SFG estimates were negative for three consecutive months during winter 1999 at all of the three Harbour sites (Fig. 6.4). Frequent periods of prolonged negative SFG were observed at all Coastal sites, predominantly during the winter, most notable of which was a 12 month period at Oteranga Bay (Fig. 6.4).
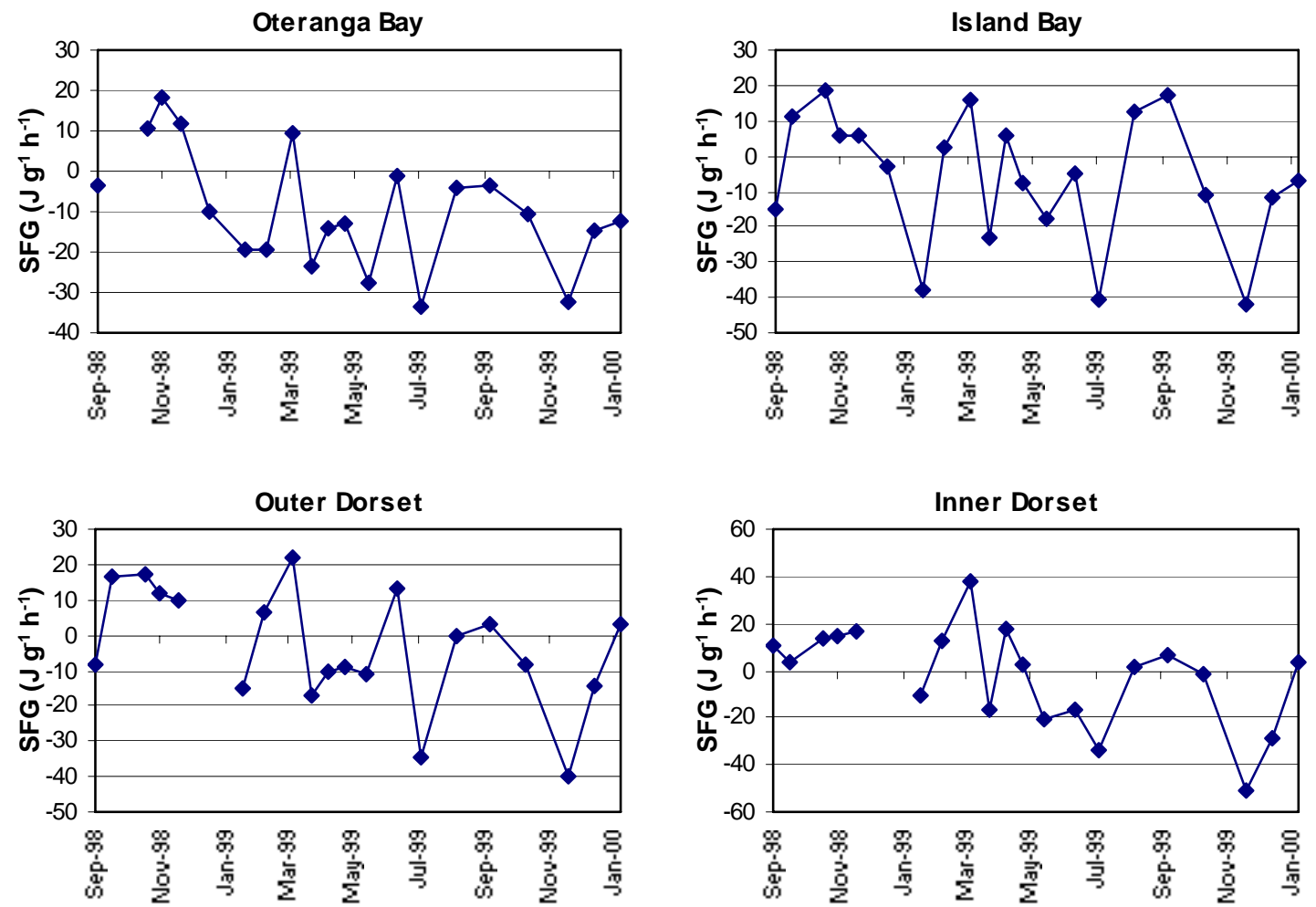

Figure 6.4. (Continued over page) Model One: Temporal variation in estimated SFG at all sites for A. maoriana. 

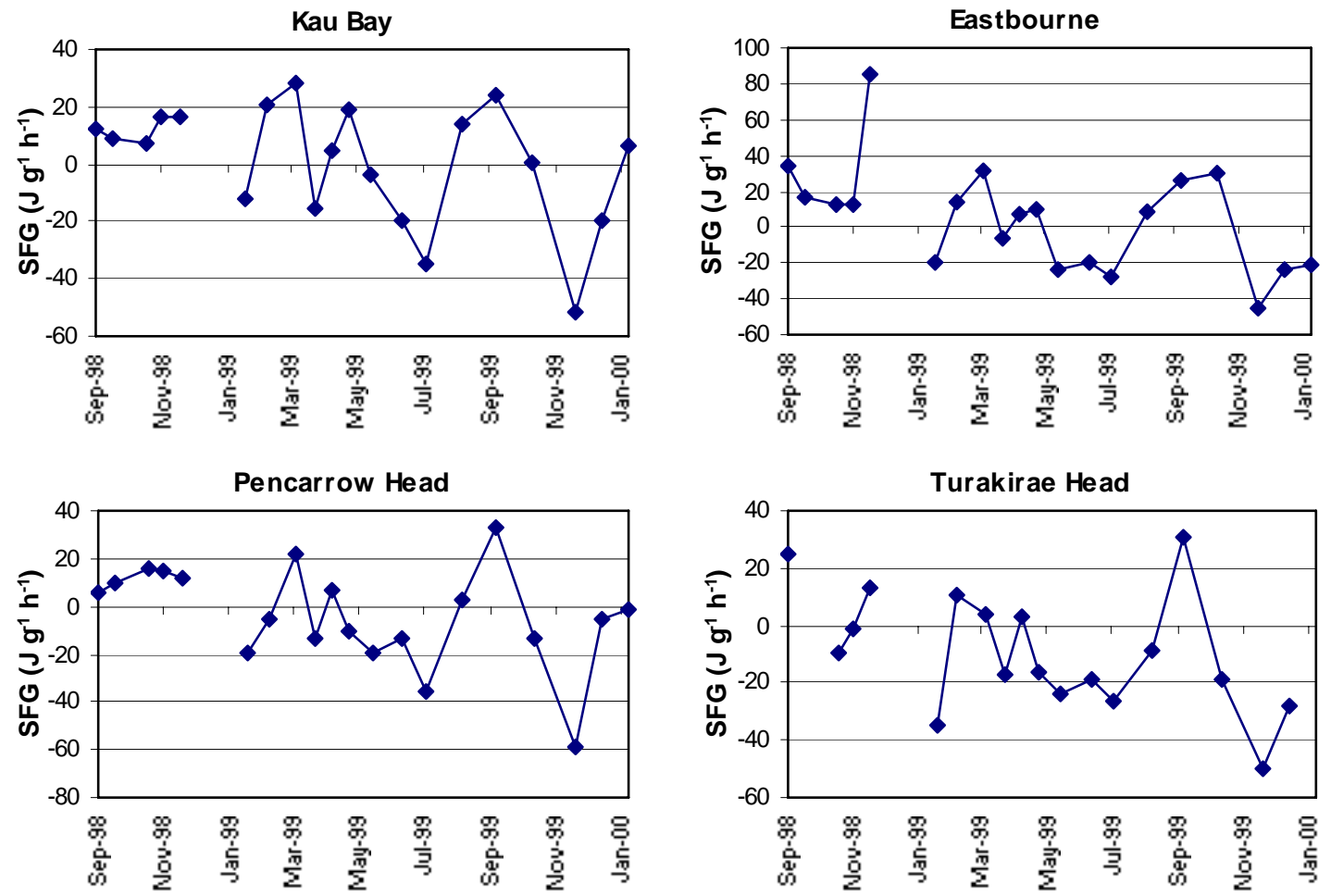

Figure 6.4. (Continued from above) Model One: Temporal variation in estimated SFG at all sites for A. maoriana.

\section{M. galloprovincialis}

Of the 159 SFG estimates for M. galloprovincialis, 49 (30.8\%) were negative. As with P. canaliculus, SFG estimates tended to be lower at Coastal sites (mean \pm SD; 33.06 $\pm 70.17)$ and increased gradually toward Harbour sites (70.81 \pm 141.99$)$ (Table $6.7 \&$ Fig. 6.5).

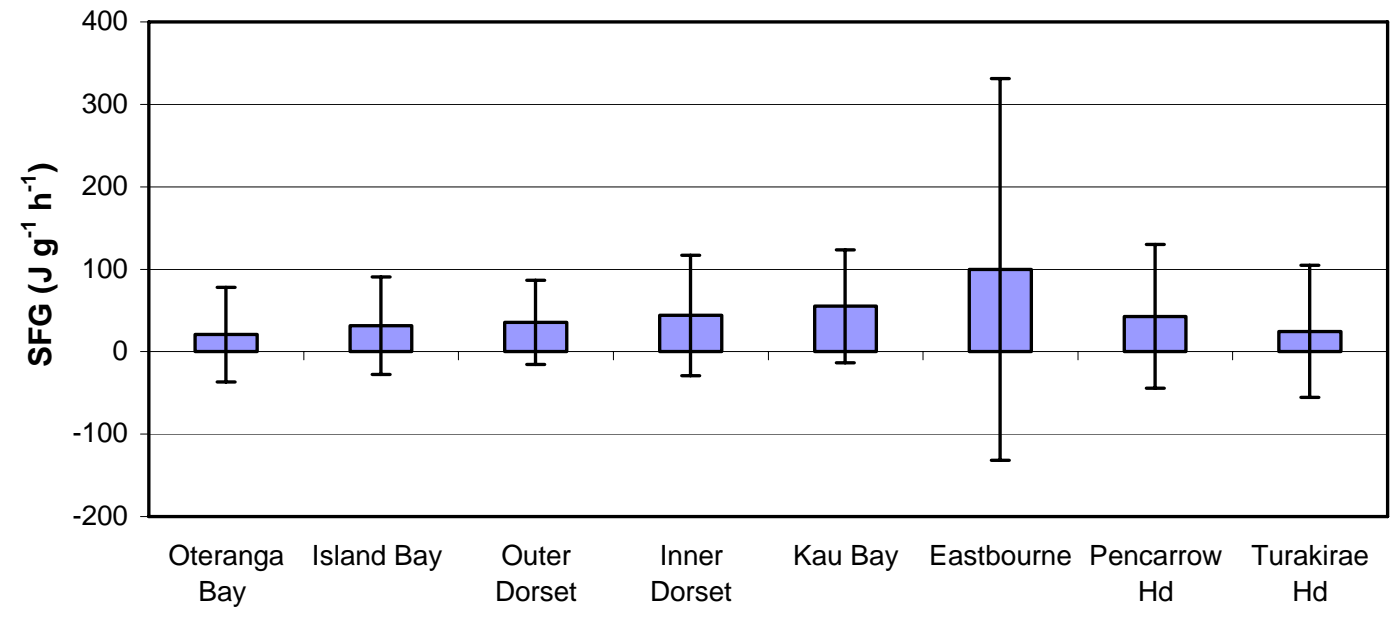

Figure 6.5. Model One: Mean estimated SFG for M. galloprovincialis. 
Table 6.7. Model One: Predicted SFG for M. galloprovincialis.

\begin{tabular}{|c|c|c|c|c|c|c|c|c|}
\hline Date & 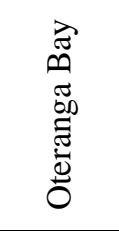 & 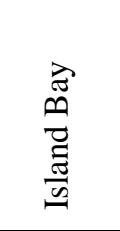 & 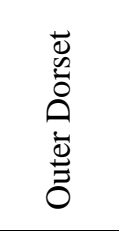 & 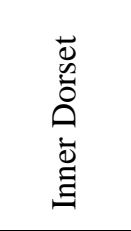 & $\begin{array}{l}\vec{\nexists} \\
\stackrel{\theta}{\Xi} \\
\vec{\Xi}\end{array}$ & 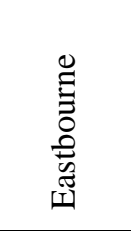 & 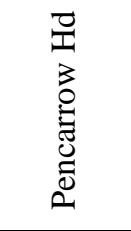 & 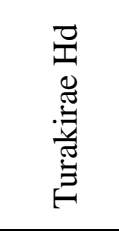 \\
\hline Sep-98 & 41.14 & 10.05 & 23.83 & 87.90 & 99.06 & 217.90 & 53.35 & 95.08 \\
\hline Sep-98 & & 77.99 & 143.97 & 69.08 & 100.57 & 141.18 & 107.01 & \\
\hline Oct-98 & 88.19 & -44.40 & 146.56 & 129.28 & 90.09 & 116.55 & 124.09 & -51.36 \\
\hline Nov-98 & 157.85 & 88.60 & 89.06 & 103.49 & 103.21 & 102.02 & 101.22 & 58.70 \\
\hline Nov-98 & 117.67 & 85.61 & 106.00 & 131.61 & 121.16 & 979.49 & 110.54 & 120.12 \\
\hline Dec-98 & 17.36 & 44.99 & & & & & & \\
\hline Jan-99 & -2.78 & -27.71 & 5.74 & 21.51 & 14.87 & -2.39 & -5.14 & -31.32 \\
\hline Feb-99 & -1.07 & -1.68 & -19.16 & 117.09 & 127.30 & 94.58 & -30.38 & 90.03 \\
\hline Mar-99 & 81.85 & 90.74 & 88.01 & 186.13 & 146.58 & 171.12 & 125.97 & 65.86 \\
\hline Mar-99 & -7.73 & -11.25 & 3.57 & -2.32 & 7.09 & 32.60 & 11.70 & 4.31 \\
\hline Apr-99 & 8.20 & 60.92 & 23.43 & 78.08 & 46.85 & 54.37 & 74.78 & 44.46 \\
\hline Apr-99 & 13.52 & 9.93 & 24.46 & 65.03 & 98.28 & -1.40 & 20.86 & 5.39 \\
\hline Мay-99 & -58.95 & -10.83 & -4.17 & -7.26 & 36.66 & -12.05 & -43.33 & -15.36 \\
\hline Jun-99 & 52.96 & 36.95 & 103.28 & -39.00 & -0.91 & -1.17 & -5.94 & -11.27 \\
\hline Jul-99 & -81.11 & -98.41 & -43.13 & -59.22 & -36.54 & -24.83 & -91.77 & -13.94 \\
\hline Aug-99 & 38.23 & 94.82 & 46.42 & 62.74 & 115.17 & 78.13 & 60.55 & 29.29 \\
\hline Sep-99 & 38.66 & 164.65 & 90.34 & 86.80 & 166.40 & 172.80 & 232.86 & 210.23 \\
\hline Oct-99 & 16.92 & 16.73 & 24.27 & 38.40 & 53.61 & 141.32 & 10.74 & -4.88 \\
\hline Nov-99 & -70.09 & -55.44 & -69.40 & -109.19 & -105.86 & -141.34 & -115.43 & -180.95 \\
\hline Dec-99 & 1.93 & 20.14 & 8.62 & -41.36 & -6.56 & -10.14 & 37.42 & -31.06 \\
\hline Jan-00 & 7.94 & 31.80 & 90.63 & 77.64 & 32.99 & -66.33 & 182.87 & \\
\hline Mean & 20.67 & 31.46 & 35.38 & 43.90 & 55.22 & 99.70 & 42.79 & 24.64 \\
\hline SD & 57.41 & 59.32 & 51.00 & 73.11 & 68.47 & 231.61 & 87.28 & 80.08 \\
\hline
\end{tabular}

Negative SFG estimates were noted on consecutive months at both Harbour and Coastal sites, although none were for prolonged periods. Most negative estimates of SFG were over the winter months (Fig. 6.6).
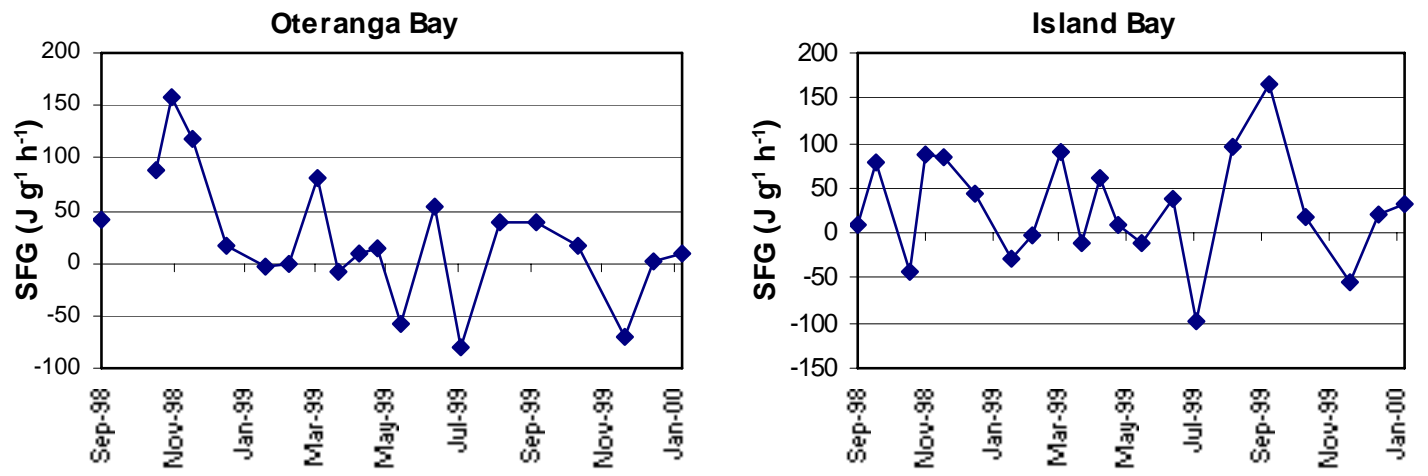

Figure 6.6. (Continued over page) Model One: Temporal variation in estimated SFG at all sites for M. galloprovincialis. 

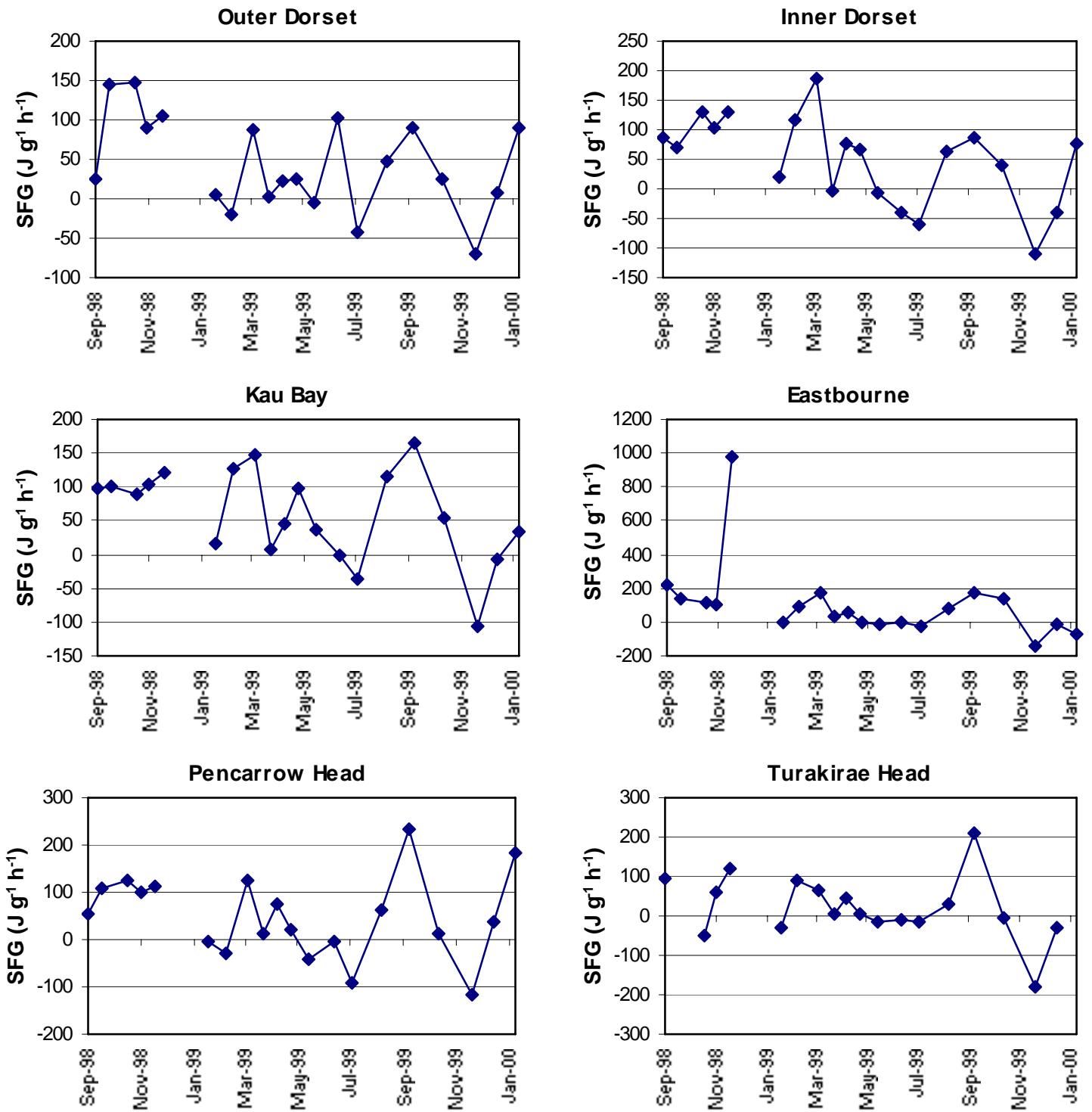

Figure 6.6. (Continued from above) Model One: Temporal variation in estimated SFG at all sites for M. galloprovincialis.

\subsubsection{SFG estimates derived from Model Two}

\section{P. canaliculus}

Results from Model Two produced much lower estimates of SFG in P. canaliculus compared to Model One. Of the 159 SFG estimates derived from this model, 83 (52\%) were negative (Table 6.8), which compares to only $14.5 \%$ negative SFG estimates for Model One. Using Model Two the mean SFG did not differ markedly between sites. The only two sites to have negative mean SFG were Oteranga Bay and Turakirae Head, both of which are Coastal sites (Fig. 6.7). Mean ( \pm SD) SFG was 0.78 $( \pm 10.87)$ at Coastal sites compared to $4.73( \pm 24.4)$ at Harbour sites. Prolonged periods of negative SFG were estimated by Model Two at Harbour and Coastal sites, most 
often in the winter months (Fig. 6.8). These periods of negative SFG were longest at Coastal sites, frequently 4-5 months in duration and up to seven months at Turakirae Head (Fig. 6.8).

Table 6.8. Model Two: Predicted SFG for P. canaliculus.

\begin{tabular}{|c|c|c|c|c|c|c|c|c|}
\hline Date & 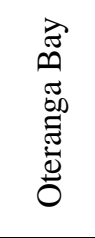 & 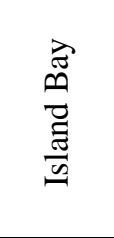 & 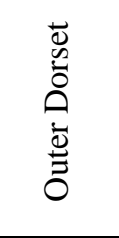 & 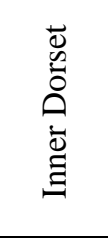 & $\begin{array}{l}\vec{\nexists} \\
\ddot{\theta} \\
\vec{\Xi}\end{array}$ & 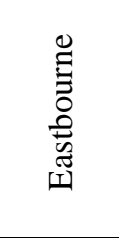 & 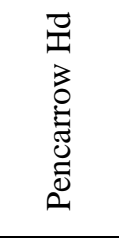 & 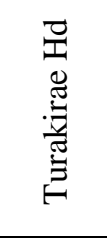 \\
\hline Sep-98 & -1.08 & -7.52 & -5.27 & 4.43 & 5.51 & 25.47 & -0.76 & 8.10 \\
\hline Sep-98 & & 3.04 & 16.74 & 3.00 & 8.25 & 13.16 & 7.40 & \\
\hline Oct-98 & 21.54 & 49.90 & 15.21 & 13.54 & 6.13 & 6.87 & 29.00 & 6.54 \\
\hline Nov-98 & 18.88 & 7.10 & 4.58 & 6.77 & 7.04 & 7.03 & 6.17 & 3.33 \\
\hline Nov-98 & 17.64 & 6.84 & 8.09 & 11.57 & 9.00 & 176.37 & 8.08 & 11.57 \\
\hline Dec-98 & -6.65 & -2.17 & & & & & & \\
\hline Jan-99 & -8.79 & -12.68 & -6.57 & -5.77 & -7.30 & -8.28 & -8.32 & -11.82 \\
\hline Feb-99 & -9.47 & 18.59 & 26.35 & 9.26 & 9.91 & 5.49 & 9.63 & 14.99 \\
\hline Mar-99 & 3.35 & 5.40 & 6.54 & 21.62 & 14.46 & 18.07 & 10.49 & 1.33 \\
\hline Mar-99 & -9.59 & -9.20 & -7.59 & -5.08 & -7.16 & -3.73 & -7.12 & -7.32 \\
\hline Apr-99 & -5.83 & 0.27 & -4.56 & 5.01 & -1.57 & 0.28 & 3.97 & -2.33 \\
\hline Apr-99 & -6.29 & -6.76 & -4.93 & 1.23 & 6.86 & -3.42 & -5.24 & -7.88 \\
\hline May-99 & -7.19 & -4.60 & 1.11 & -8.19 & -3.66 & -9.49 & -3.16 & -8.95 \\
\hline Jun-99 & 4.80 & -1.21 & 7.06 & -1.87 & -8.99 & -8.61 & -2.07 & -5.72 \\
\hline Jul-99 & -8.68 & -10.18 & -10.89 & -9.69 & -11.41 & -9.76 & -8.76 & -10.45 \\
\hline Aug-99 & 0.88 & 5.39 & -0.58 & 1.59 & 8.51 & 2.92 & 0.21 & -4.53 \\
\hline Sep-99 & -4.38 & 13.29 & 3.42 & 4.31 & 16.94 & 17.14 & 27.47 & 22.55 \\
\hline Oct-99 & -4.31 & -4.42 & -4.94 & -3.53 & -0.73 & 14.60 & -4.55 & -6.98 \\
\hline Nov-99 & -8.60 & -12.11 & -11.03 & -11.67 & -11.87 & -9.81 & -12.09 & -9.75 \\
\hline Dec-99 & -5.11 & -4.40 & -4.87 & -8.93 & -7.58 & -9.35 & -1.62 & -9.48 \\
\hline Jan-00 & -3.18 & -1.39 & 3.62 & 3.91 & 3.45 & -8.39 & 2.28 & \\
\hline Mean & -1.10 & 1.58 & 1.57 & 1.58 & 1.79 & 10.83 & 2.55 & -0.93 \\
\hline SD & 9.72 & 13.77 & 9.80 & 8.62 & 8.76 & 40.50 & 10.90 & 10.03 \\
\hline
\end{tabular}

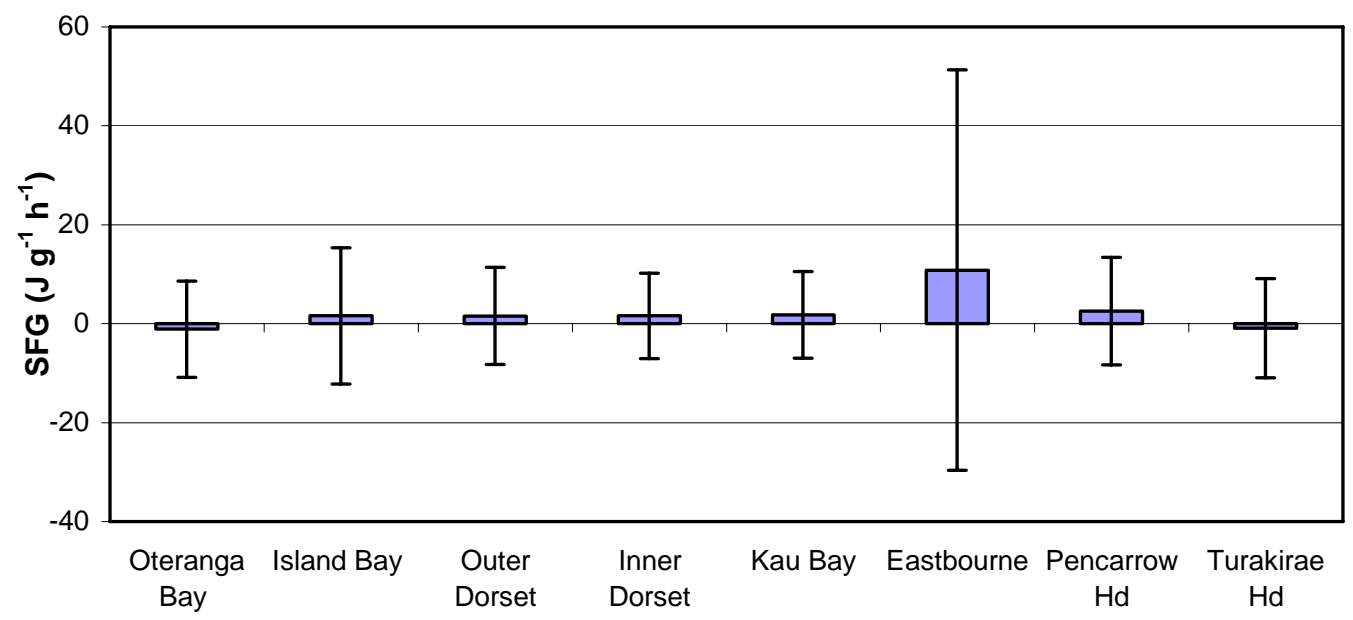

Figure 6.7. Model Two: Mean estimated SFG for $P$. canaliculus. 

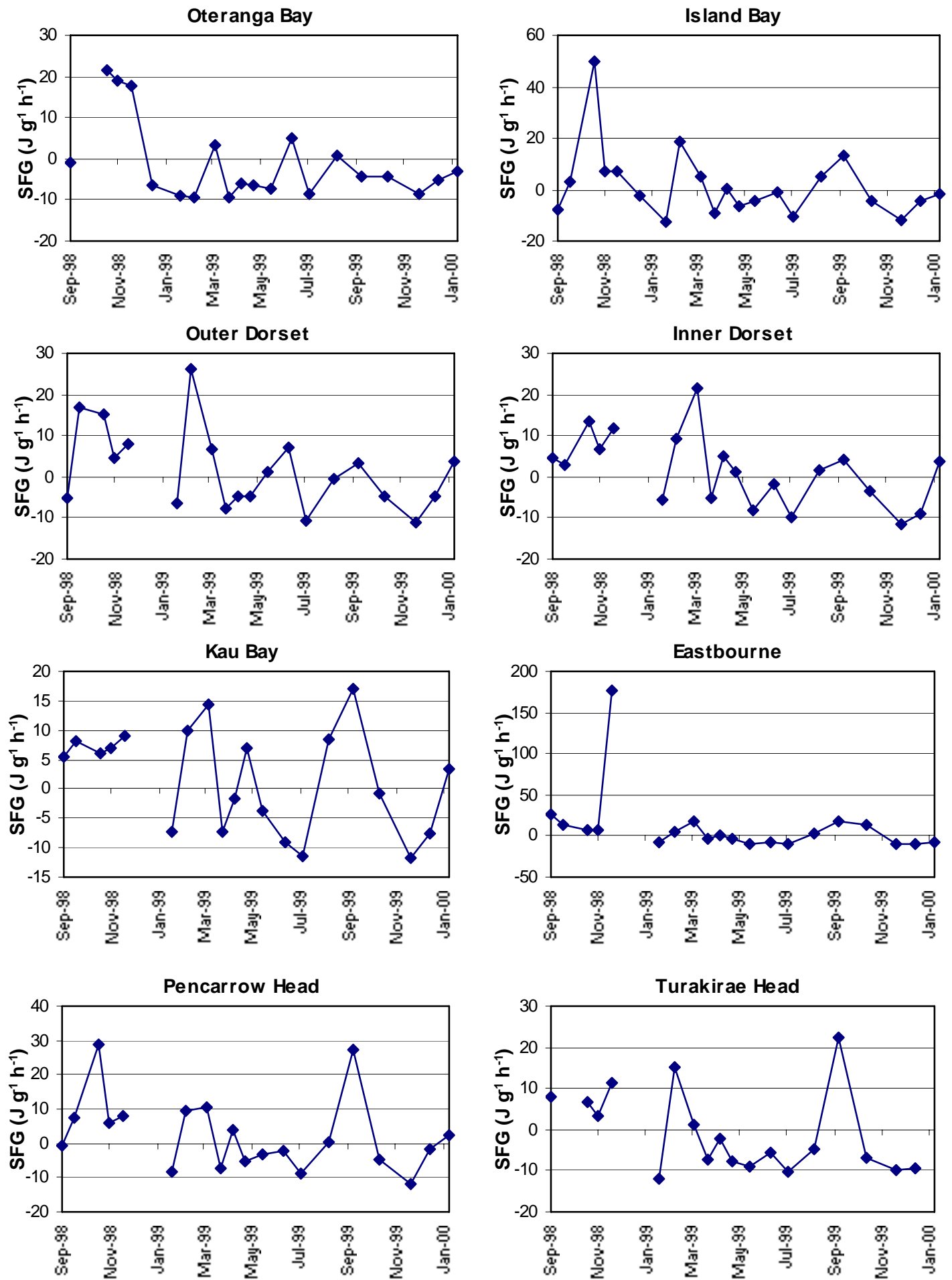

Figure 6.8. Model Two: Temporal variation in estimated SFG at all sites for $P$. canaliculus.

\section{A. maoriana}

SFG estimates from Model Two for A. maoriana were higher than those derived from Model One (Table 6.9). Only 7 (4.4\%) of the 159 modelled observations were negative, compared to 52.2\% from Model One. Further, there was very little 
difference in SFG values between sites using Model Two; mean ( \pm SD) SFG was $23.93( \pm 21.05)$ at Coastal sites and $26.19( \pm 18.27)$ at Harbour sites (Fig. 6.9). SFG estimates were rarely negative at any of the eight sites, although Coastal sites had slightly lower SFG. As with the other species, estimated SFG was lowest in winter (Fig. 6.10).

Table 6.9. Model Two: Predicted SFG for A. maoriana.

\begin{tabular}{|c|c|c|c|c|c|c|c|c|}
\hline Date & 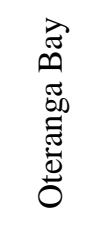 & $\begin{array}{l}\vec{\Xi} \\
\oplus \\
\vec{\Xi} \\
\frac{\vec{\Xi}}{\omega}\end{array}$ & 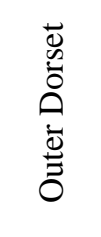 & 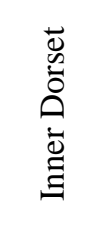 & $\begin{array}{l}\vec{\nabla} \\
\oplus \\
\vec{\nabla} \\
\vec{E}\end{array}$ & 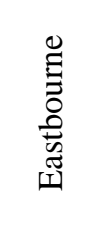 & 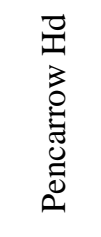 & 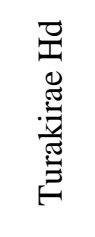 \\
\hline Sep-98 & 21.00 & 7.07 & 11.71 & 31.54 & 32.57 & 62.05 & 20.97 & 39.83 \\
\hline Sep-98 & & 30.13 & 49.41 & 28.35 & 36.70 & 43.33 & 34.17 & \\
\hline Oct-98 & 63.16 & 131.52 & 46.61 & 44.58 & 33.26 & 33.05 & 73.93 & 41.78 \\
\hline Nov-98 & 52.00 & 34.91 & 32.05 & 35.52 & 36.91 & 35.64 & 34.74 & 28.90 \\
\hline Nov-98 & 52.99 & 34.77 & 35.99 & 41.52 & 37.95 & 75.46 & 36.17 & 41.75 \\
\hline Dec-98 & 9.14 & 18.84 & & & & & & \\
\hline Jan-99 & 4.75 & -4.40 & 10.42 & 10.49 & 7.70 & 5.84 & 5.85 & -1.96 \\
\hline Feb-99 & 3.15 & 64.36 & 81.59 & 37.69 & 40.66 & 33.97 & 47.62 & 51.88 \\
\hline Mar-99 & 29.64 & 35.15 & 36.63 & 62.74 & 50.39 & 54.65 & 42.80 & 25.66 \\
\hline Mar-99 & 2.88 & 3.97 & 7.13 & 13.85 & 7.99 & 16.01 & 8.06 & 8.55 \\
\hline Apr-99 & 12.02 & 22.36 & 14.22 & 33.40 & 19.83 & 23.64 & 30.77 & 18.08 \\
\hline Apr-99 & 10.78 & 9.94 & 13.60 & 25.23 & 38.15 & 22.21 & 12.94 & 6.48 \\
\hline May-99 & 10.90 & 15.24 & 27.62 & 6.85 & 14.77 & 3.36 & 19.98 & 5.27 \\
\hline Jun-99 & 32.33 & 21.07 & 35.65 & 22.95 & 4.19 & 5.08 & 20.82 & 12.84 \\
\hline Jul-99 & 7.71 & 3.64 & 0.94 & 4.50 & -0.83 & 3.54 & 7.42 & 1.08 \\
\hline Aug-99 & 25.37 & 33.01 & 22.69 & 25.70 & 37.01 & 28.80 & 23.61 & 14.01 \\
\hline Sep-99 & 13.14 & 39.70 & 26.47 & 29.87 & 49.69 & 49.72 & 61.73 & 55.67 \\
\hline Oct-99 & 15.25 & 14.92 & 12.30 & 15.38 & 21.72 & 52.56 & 14.68 & 9.66 \\
\hline Nov-99 & 7.58 & -2.52 & 0.92 & -1.36 & -2.06 & 4.75 & -3.90 & 4.36 \\
\hline Dec-99 & 13.86 & 14.49 & 13.97 & 6.04 & 8.32 & 3.49 & 20.19 & 4.39 \\
\hline Jan-00 & 17.83 & 19.73 & 28.86 & 29.36 & 28.61 & 6.54 & 26.34 & \\
\hline Mean & 20.27 & 26.09 & 25.44 & 25.21 & 25.18 & 28.18 & 26.95 & 20.46 \\
\hline SD & 17.51 & 29.10 & 19.34 & 15.82 & 16.61 & 22.44 & 19.15 & 18.46 \\
\hline
\end{tabular}

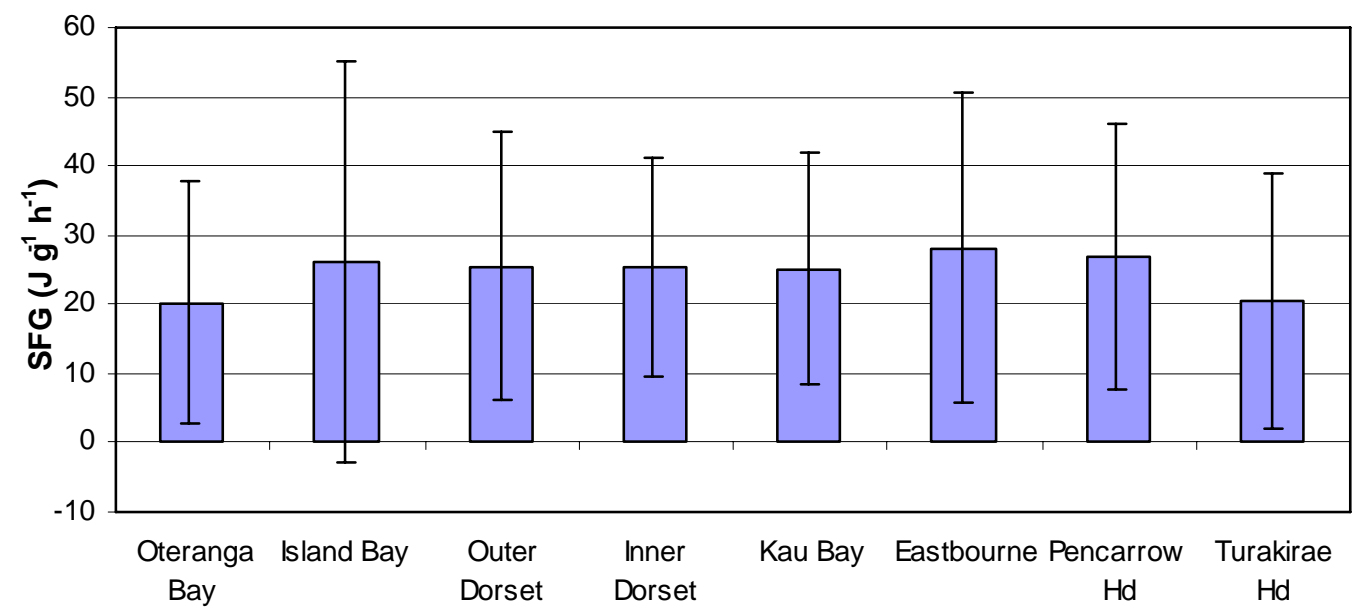

Figure 6.9. Model Two: Mean estimated SFG A. maoriana. 

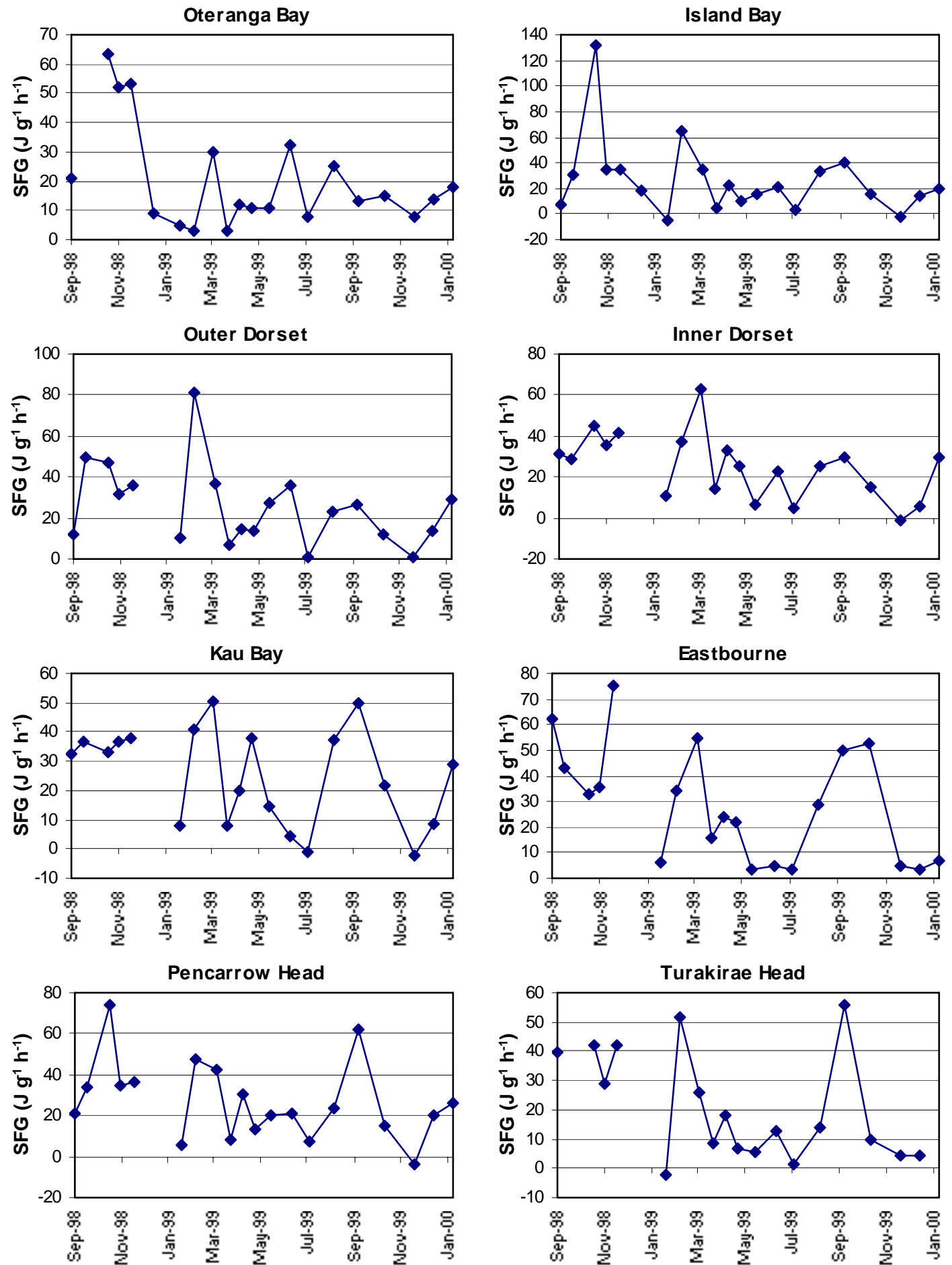

Figure 6.10. Model Two: Temporal variation in estimated SFG at all sites for A. maoriana.

\section{M. galloprovincialis}

Of the 159 modelled SFG values derived from Model Two, 80 (50\%) were negative (Table 6.10). This is greater than the $30.8 \%$ negative SFG for the model derived from Model One for this species. Both models estimate greater mean ( \pm SD) SFG at Harbour sites (14.10 \pm 52.45$)$ than at Coastal sites (0.31 \pm 16.54$)$ (Fig. 6.11). Prolonged 
periods of negative SFG at Coastal sites were estimated by Model Two, and these were frequently of 4-5 months duration (Fig. 6.12). Shorter periods of negative SFG were estimated for Harbour sites (Fig. 6.12).

Table 6.10. Model Two: Predicted SFG for M. galloprovincialis.

\begin{tabular}{|c|c|c|c|c|c|c|c|c|}
\hline Date & 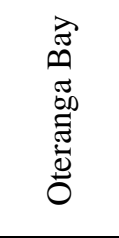 & 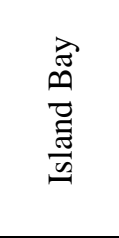 & 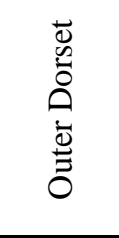 & 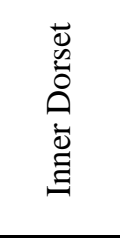 & $\begin{array}{l}\vec{\nexists} \\
\oplus \\
\vec{\nabla} \\
\vec{\Xi}\end{array}$ & 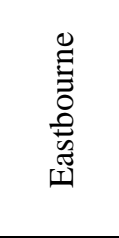 & $\begin{array}{l}\text { 푸 } \\
3 \\
0 \\
0 \\
0 \\
0 \\
0 \\
0\end{array}$ & 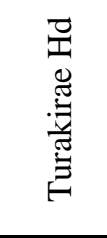 \\
\hline Sep-98 & -1.78 & -10.86 & -6.02 & 13.86 & 15.93 & 60.82 & 7.24 & 35.01 \\
\hline Sep-98 & & 13.39 & 25.84 & 5.23 & 13.41 & 25.81 & 13.94 & \\
\hline Oct-98 & 15.88 & 18.63 & 27.11 & 21.33 & 10.56 & 18.28 & 25.70 & -9.10 \\
\hline Nov-98 & 29.64 & 9.56 & 14.94 & 19.18 & 21.37 & 17.39 & 19.26 & 1.54 \\
\hline Nov-98 & 19.09 & 9.20 & 14.75 & 24.02 & 22.54 & 381.30 & 17.36 & 19.12 \\
\hline Dec-98 & -7.40 & -1.17 & & & & & & \\
\hline Jan-99 & -13.30 & -19.15 & -10.50 & -7.65 & -8.64 & -13.11 & -13.52 & -18.67 \\
\hline Feb-99 & -13.33 & 2.76 & 5.97 & 18.44 & 28.41 & 17.74 & -5.27 & 15.72 \\
\hline Mar-99 & 11.98 & 19.67 & 30.24 & 61.33 & 41.09 & 48.32 & 30.37 & 5.65 \\
\hline Mar-99 & -15.15 & -15.09 & -12.01 & -11.53 & -11.09 & -4.15 & -9.70 & -11.55 \\
\hline Apr-99 & -9.86 & 8.50 & -7.05 & 23.69 & 5.97 & 9.86 & 8.69 & 4.06 \\
\hline Apr-99 & -9.15 & -5.98 & -6.31 & 4.68 & 23.32 & 7.61 & -7.35 & -11.72 \\
\hline May-99 & -16.99 & -12.26 & -8.30 & -13.54 & -1.70 & -15.20 & -13.86 & -14.78 \\
\hline Jun-99 & 1.29 & -3.04 & 17.86 & -12.55 & -13.27 & -13.06 & -10.14 & -12.60 \\
\hline Jul-99 & -18.54 & -19.65 & -18.12 & -18.26 & -18.89 & -16.09 & -19.24 & -16.22 \\
\hline Aug-99 & -2.14 & 15.80 & 0.87 & 3.19 & 19.56 & 10.41 & 4.19 & -6.03 \\
\hline Sep-99 & -1.53 & 28.22 & 6.61 & 9.52 & 37.65 & 40.67 & 60.08 & 53.14 \\
\hline Oct-99 & -7.50 & -7.78 & -6.09 & 0.36 & 1.69 & 43.05 & -9.23 & -12.58 \\
\hline Nov-99 & -18.25 & -20.05 & -19.21 & -19.62 & -19.50 & -20.11 & -18.80 & -20.03 \\
\hline Dec-99 & -10.45 & -8.08 & -9.87 & -16.94 & -13.02 & -15.36 & -3.04 & -16.48 \\
\hline Jan-00 & -8.99 & -4.40 & 5.58 & 6.18 & 9.42 & -13.83 & 1.38 & \\
\hline Mean & -3.82 & -0.09 & 2.32 & 5.55 & 8.24 & 28.52 & 3.90 & -0.86 \\
\hline SD & 13.36 & 14.24 & 15.15 & 19.69 & 18.35 & 86.52 & 19.70 & 20.16 \\
\hline
\end{tabular}

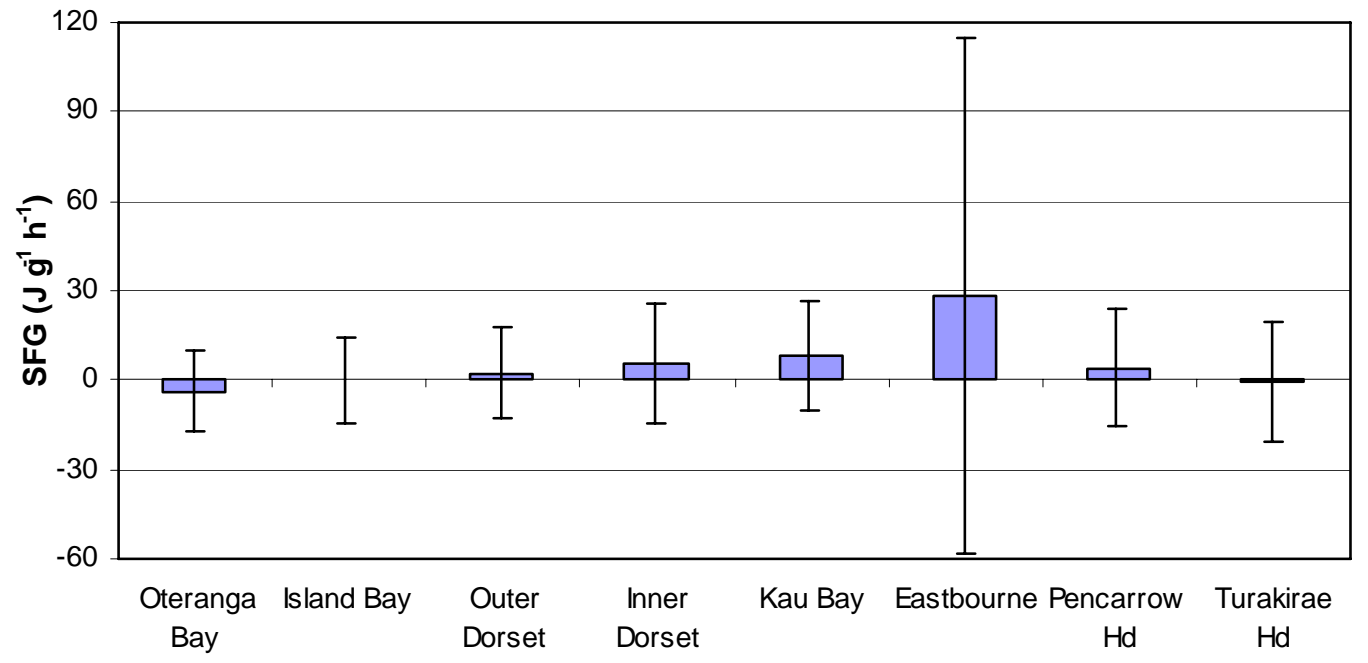

Figure 6.11. Model Two: Mean estimated SFG for M. galloprovincialis. 

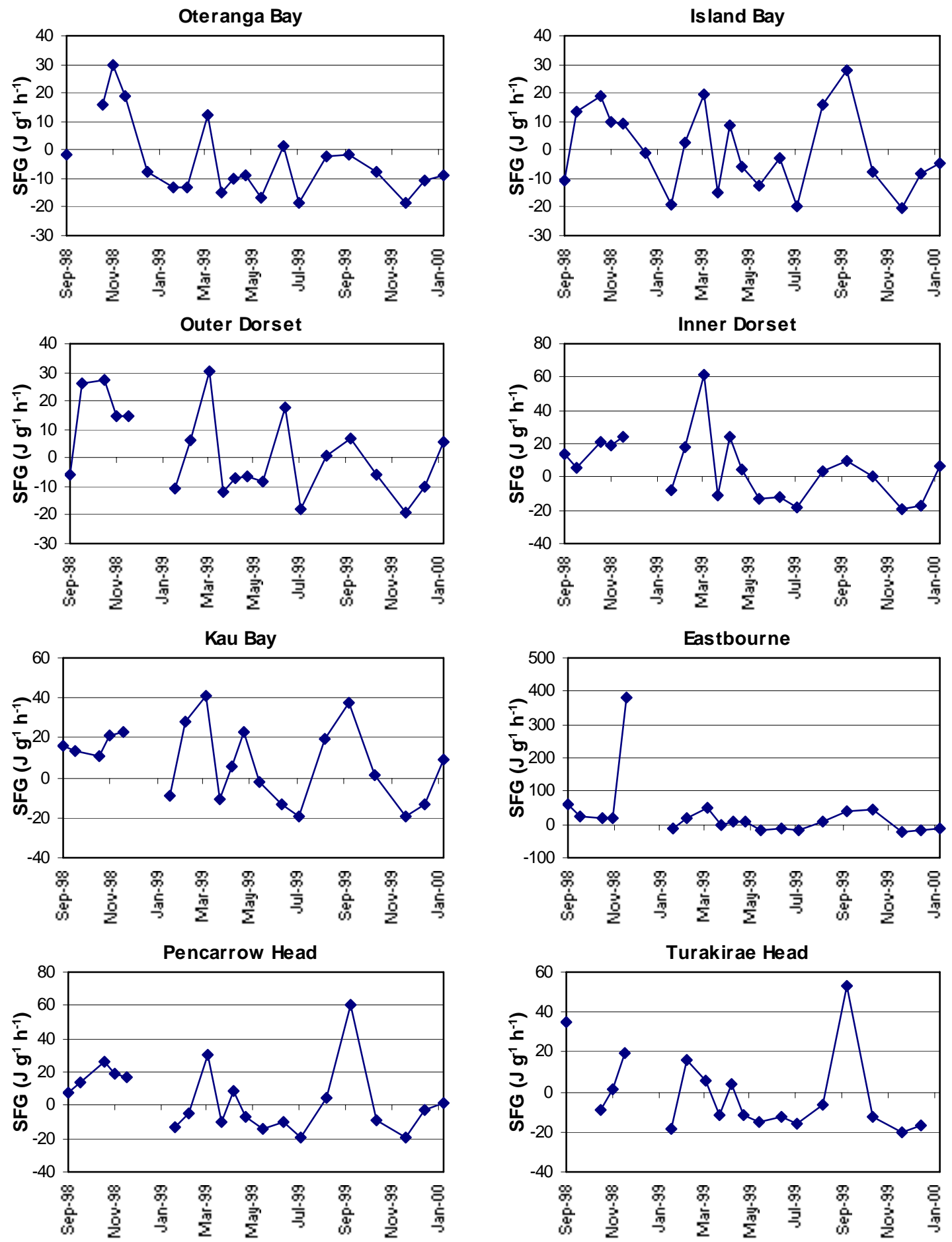

Figure 6.12. Model Two: Temporal variation in estimated SFG at all sites for M. galloprovincialis.

\subsubsection{Model validation}

Both models were used to estimate SFG for all three species using seston data collected in feeding experiments reported in Chapter Five. Modelled SFG values were compared to actual (i.e. experimental) SFG estimates for each species. Model One 
gave good estimates of SFG for all species. A comparison of estimated SFG for $P$. canaliculus shows that Model One fits the experimental data well (Table 6.11 \& Fig. 6.13). Data derived from Model Two tend to under-estimate SFG values (Table 6.11 Fig. 6.14). Of the ten SFG experiments, estimates from Model One are closest to the experimental SFG data on six occasions, while estimates from Model Two are closest on four occasions (Table 6.11). Both Models give SFG estimates within the error bars of the actual data on six of the ten occasions (Figs. $6.13 \& 6.14$ ).

Table 6.11. Model validation: Comparison of SFG estimates from experimental data and Models One and Two for $P$. canaliculus.

\begin{tabular}{c|cccc}
\hline & \multicolumn{2}{|c}{ Experimental SFG $\left(\mathrm{J} \mathrm{g}^{-1} \mathrm{~h}^{-1}\right)$} & \multicolumn{2}{c}{ Modelled SFG $\left(\mathrm{J} \mathrm{g}^{-1} \mathrm{~h}^{-1}\right)$} \\
\cline { 2 - 5 } Jun-98 & Mean & SD & Model One & Model Two \\
Jun-98 & -5.354 & 10.155 & -26.350 & -13.613 \\
Mar-99 & 228.158 & 67.050 & 207.667 & 25.800 \\
Mar-99 & -7.354 & 53.342 & 11.730 & -5.191 \\
Jun-99 & 51.698 & 27.330 & 18.244 & -3.410 \\
Jun-99 & 19.883 & 28.014 & -2.082 & -3.758 \\
Feb-00 & 20.577 & 30.071 & 18.516 & -4.124 \\
Feb-00 & 13.998 & 27.104 & 49.512 & -3.365 \\
Sep-00 & 13.140 & 11.250 & 31.441 & -5.988 \\
Sep-00 & 10.262 & 32.058 & 24.350 & -11.323 \\
\hline
\end{tabular}

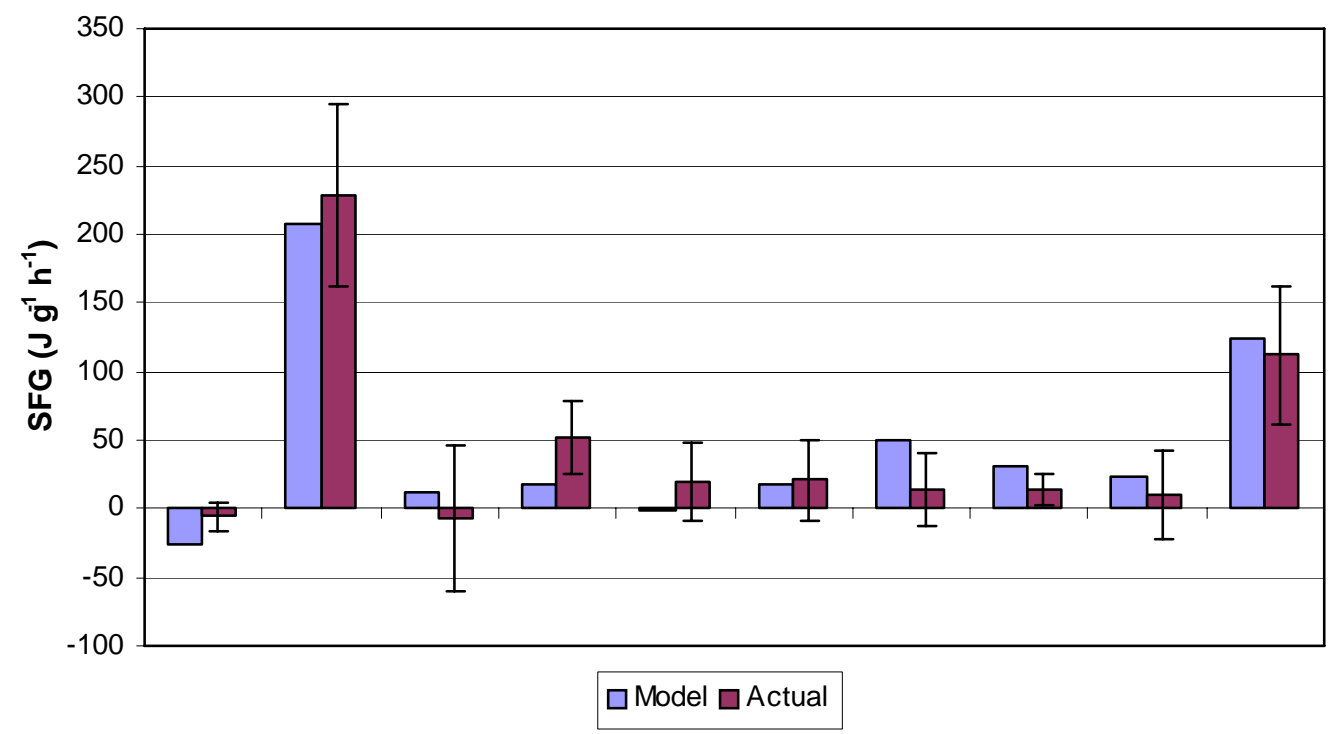

Figure 6.13. Model One validation: Comparison between experimental SFG and modelled SFG for P. canaliculus. 


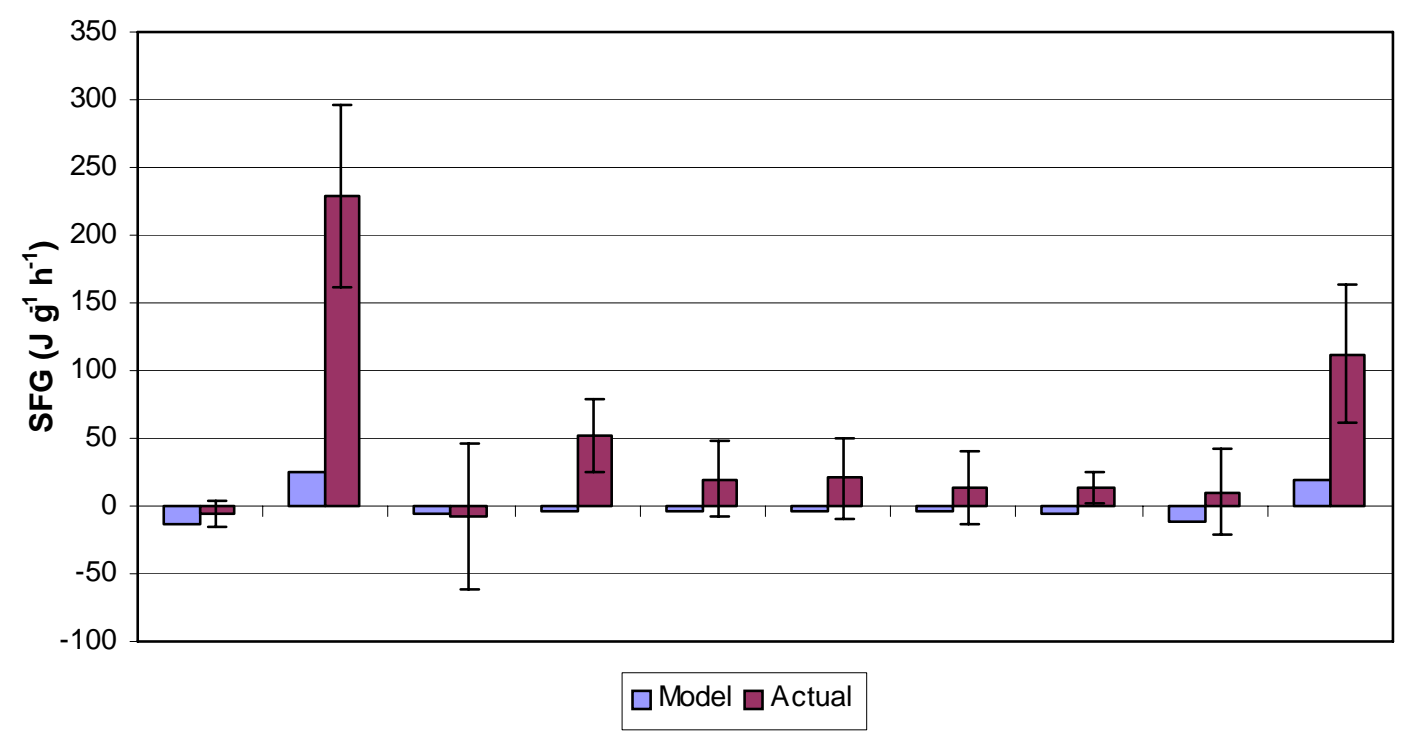

Figure 6.14. Model Two validation: Comparison between experimental SFG and modelled SFG for P. canaliculus.

Estimates of SFG from data derived from Model One also fit very well for $A$. maoriana (Table 6.12 \& Fig. 6.15). Model Two tends to over-estimate SFG, particularly at higher seston concentrations (Table 6.12 \& Fig. 6.16). Of the 15 experiments compared in Table 6.12, Model One gives a better estimate of SFG on 13 occasions. Model One estimates SFG within the error bars of the actual estimates on 12 of 15 occasions, while estimates derived from Model Two are within the error bars on five occasions (Figs, 6.15 \& 6.16).

Table 6.12. Model validation: Comparison of SFG estimates from experimental data and Models One and Two for A. maoriana.

\begin{tabular}{r|cccc}
\hline & \multicolumn{2}{|c}{ Experimental SFG $\left(\mathrm{J} \mathrm{g}^{-1} \mathrm{~h}^{-1}\right)$} & \multicolumn{2}{c}{ Modelled SFG $\left(\mathrm{J} \mathrm{g}^{-1} \mathrm{~h}^{-1}\right)$} \\
\cline { 2 - 5 } June-98 & Mean & $\mathrm{SD}$ & Model One & Model Two \\
June-98 & 12.300 & 17.062 & -1.400 & 8.982 \\
June-98 & 22.299 & 23.044 & 25.748 & 40.093 \\
June-98 & 89.299 & 82.080 & 95.131 & 68.531 \\
June-98 & 35.202 & 39.758 & 49.037 & 151.084 \\
June-98 & 66.021 & 85.537 & 49.124 & 262.638 \\
June-98 & 94.573 & 47.653 & 78.255 & 291.704 \\
Mar-99 & 77.149 & 101.256 & 89.053 & 371.165 \\
Mar-99 & -65.007 & 47.102 & -28.054 & 3.339 \\
Jun-99 & -4.090 & 9.039 & -16.883 & 9.663 \\
Jun-99 & -21.690 & 12.237 & -27.027 & 13.034 \\
Feb-00 & -19.475 & 42.142 & -12.911 & 11.200 \\
Feb-00 & 19.242 & 5.957 & -16.648 & 5.451 \\
Sept-00 & -20.715 & 14.870 & -8.264 & 10.551 \\
Sept-00 & -16.463 & 21.188 & -0.039 & 54.565 \\
\hline
\end{tabular}




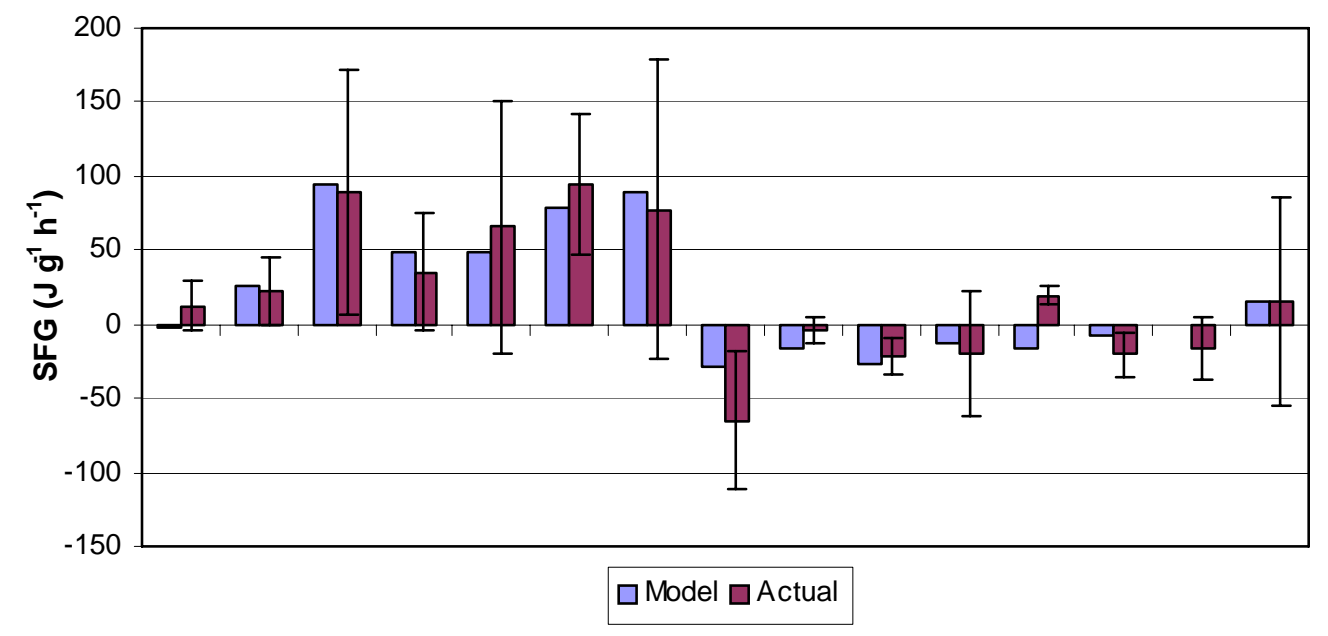

Figure 6.15. Model One validation: Comparison between experimental SFG and modelled SFG for A. maoriana.

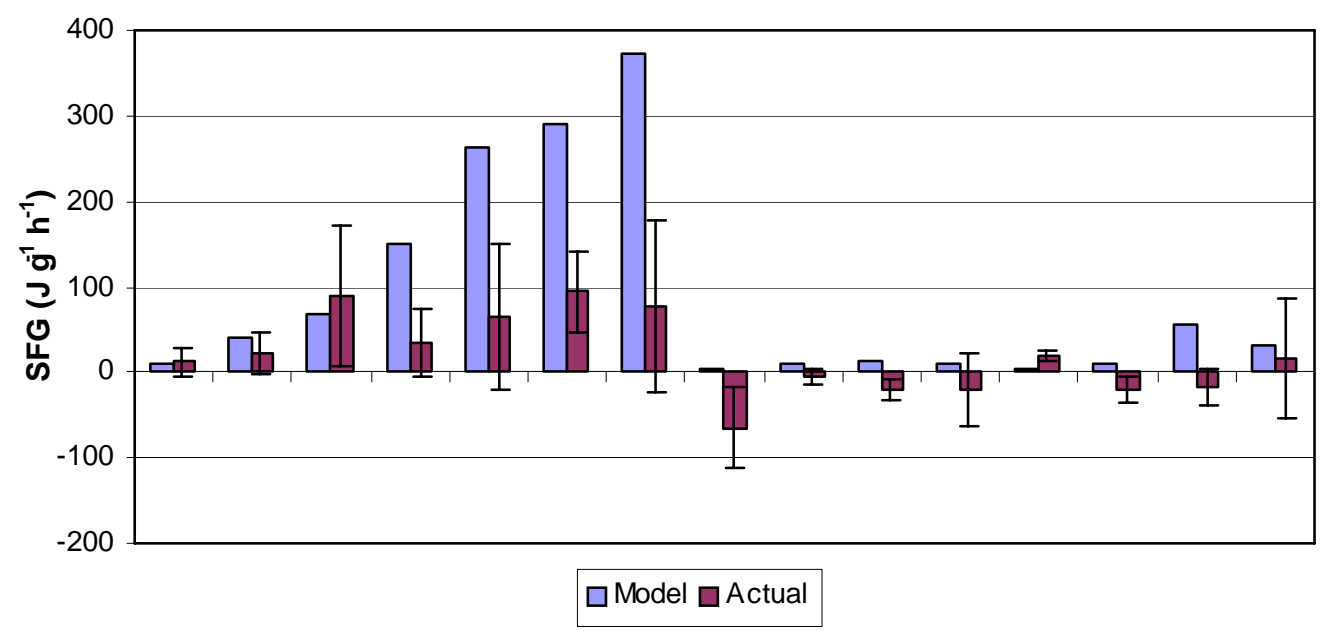

Figure 6.16. Model Two validation: Comparison between experimental SFG and modelled SFG for A. maoriana.

As with the other two species, SFG estimates derived from Model One fit well for $M$. galloprovincialis. Of the ten experiments, SFG estimates derived from Model One were closest to actual SFG data on eight occasions, while Model Two was closest the on remaining two occasions. SFG estimates from Model One were within the error bars of the actual SFG estimates on nine occasions (Table 6.13 \& Fig. 6.17). SFG estimates derived from Model Two also fit reasonably well, with SFG estimates within the error bars of the actual observations on nine of the ten occasions (Table 6.13 \& Fig. 6.18). 
Table 6.13. Model validation: Comparison of SFG estimates from experimental data and Models One and Two for M. galloprovincialis.

\begin{tabular}{r|cccc}
\hline & \multicolumn{2}{|c}{ Experimental SFG $\left(\mathrm{J} \mathrm{g}^{-1} \mathrm{~h}^{-1}\right)$} & \multicolumn{2}{c}{ Modelled SFG $\left(\mathrm{J} \mathrm{g}^{-1} \mathrm{~h}^{-1}\right)$} \\
\cline { 2 - 5 } Jun-98 & Mean & SD & Model One & Model Two \\
Jun-98 & -8.283 & 31.330 & -13.440 & 11.211 \\
Mar-99 & -15.867 & 19.659 & -14.389 & -12.386 \\
Mar-99 & -1.213 & 29.797 & 5.735 & -10.293 \\
Jun-99 & -3.605 & 10.290 & -3.546 & -12.472 \\
Jun-99 & 31.286 & 22.741 & 16.045 & -7.970 \\
Feb-00 & -34.207 & 22.584 & -23.999 & -12.814 \\
Feb-00 & 1.353 & 16.252 & 27.081 & -3.482 \\
Sept-00 & 13.889 & 33.130 & -9.564 & -14.953 \\
Sept-00 & 39.143 & 80.515 & 28.420 & -3.745 \\
\hline
\end{tabular}

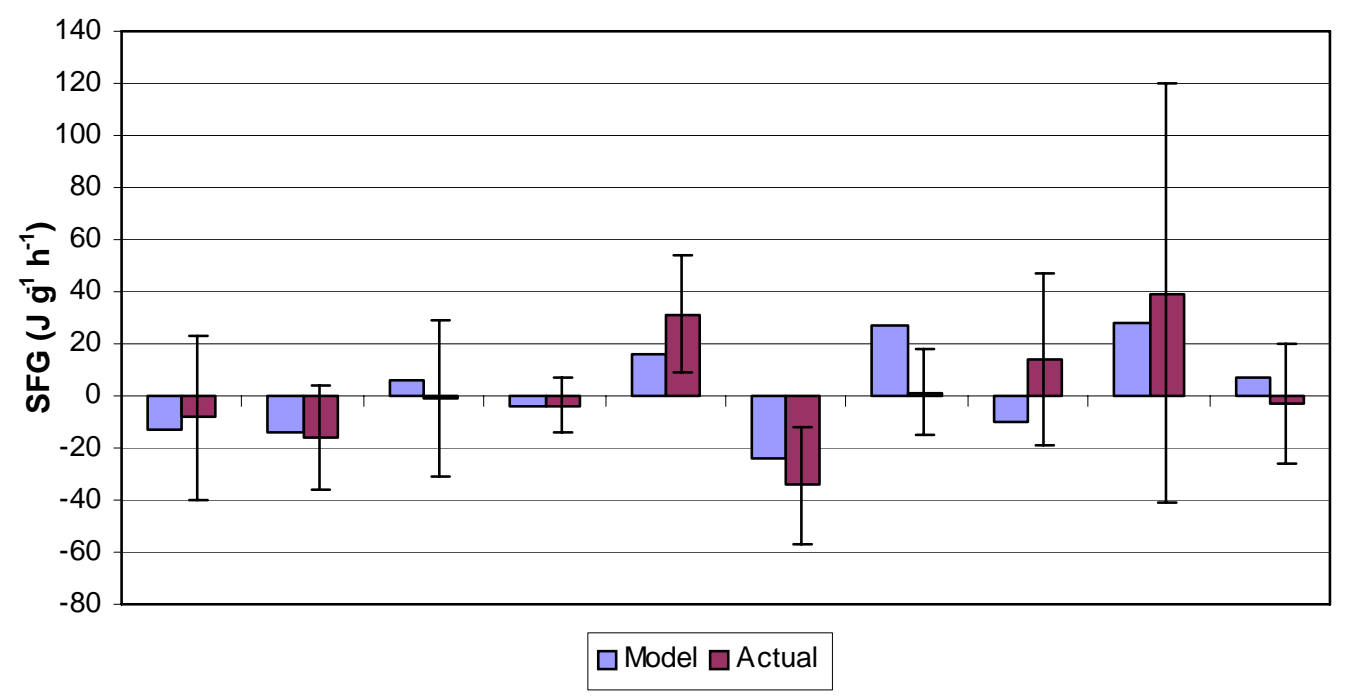

Figure 6.17. Model One validation: Comparison between experimental SFG and modelled SFG for M. galloprovincialis.

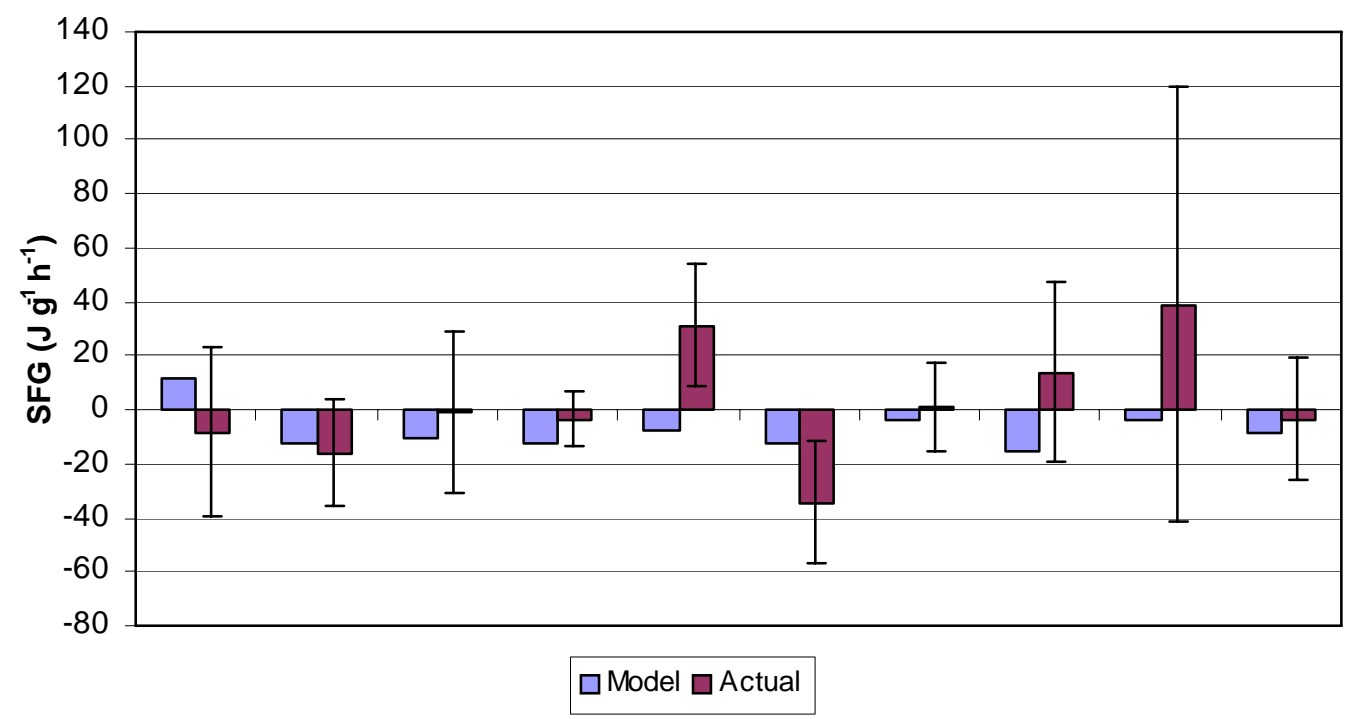

Figure 6.18. Model Two validation: Comparison between experimental SFG and modelled SFG for M. galloprovincialis. 


\subsection{Discussion}

In all three species, rates of pseudofaecal (PSF) production (percent filtered ration discarded as pseudofaeces) in feeding experiments conducted at IBML were similar to the quantities reported in Grant and Bacher (1998). These authors used a step function compiled from the data of numerous published studies for Mytilus edulis: no rejection at TPM of $0-5 \mathrm{mg} \mathrm{l}^{-1}, 20 \%$ rejection at pseudofaecal threshold up to TPM of $10 \mathrm{mg}$ $\mathrm{l}^{-1}$, and $40 \%$ rejection from TPM of $10-40 \mathrm{mg} \mathrm{l}^{-1}$. These data are similar to findings at IBML where $P$. canaliculus experienced a mean pseudofaecal production of $10.3 \%$ ( \pm 5.36 ) of filtered ration for TPM ranging from 5.6-15.0 $\mathrm{mg} \mathrm{l}^{-1}$. A. maoriana produced pseudofaeces as a percentage of filtered ration with a mean of $19.6 \%$ ( \pm 12.6 ) for TPM ranging from 7.4-36.8 $\mathrm{mg} \mathrm{l}^{-1}$ and $M$. galloprovincialis produced a mean of 35.8\% $( \pm 28.4)$ for TPM ranging from 9.1-14.4 $\mathrm{mg} \mathrm{l}^{-1}$. The net enrichment of ingested organic material was positive for P. canaliculus and A. maoriana. However, M. galloprovincialis did not enrich ingested material (by preferential selection for organic material) enough to compensate for the high pseudofaecal loss and therefore experienced a net energy loss due to pseudofaecal production.

SFG estimates from both Models were close to experimental data for all three species. Estimates for $P$. canaliculus were within the error bars of the actual data on six of ten occasions using both models. Estimates for A. maoriana showed a greater discrepancy between the models. Model One predicted SFG within the error bars of the actual data on 12 of 15 occasions, compared to five of 15 for Model Two. Given the greater range of seston conditions to which $A$. maoriana was exposed, one might assume that Model Two, being constructed over a greater seston range, would have produced closer SFG estimates. Estimates of SFG for M. galloprovincialis are reasonably close to those observed in experiments, both models predicting SFG within the error bars on nine of ten occasions. However, one must take into account that on many occasions the range of actual SFG from experiments in Chapter Five is large, and only a very poor model would not predict SFG to within one standard deviation.

SFG estimates from Model One suggest that food limitation is occurring only rarely in $P$. canaliculus when fed on Coastal waters. This is in contrast to data from feeding and condition experiments (Chapters Four \& Five) which suggest food limitation is occurring at some times of the year. One potential problem is that Model One was 
based on physiological data obtained over a relatively narrow range of seston regimes at IBML (Table 6.1). When this model is used to estimate higher levels of seston, it may become inaccurate as it is operating outside the parameters on which it was based. Model One is therefore a low seston model being used to predict SFG at moderate to high seston levels. The same could also be said about the model for $M$. galloprovincialis, as this too was based on a relatively narrow range of seston characteristics (Table 6.1). The model for M. galloprovincialis suggests positive mean SFG at all sites, although the variation is high (Table 6.7). The general trend is toward lower SFG at Coastal sites and higher SFG within the Harbour (Figs. 6.1 \& 6.3). Model One for A. maoriana was constructed over a far broader range of seston characteristics (Table 6.1), and was based on more observations. It is interesting to note that this model predicts very different results for $A$. maoriana compared to those for $P$. canaliculus and $M$. galloprovincialis. The model suggests mean SFG is generally negative at Coastal sites and positive at Harbour sites (Fig. 6.3). Model One also gives better agreement with observed SFG data for $A$. maoriana than either $P$. canaliculus or M. galloprovincialis.

Model Two, which is derived from feeding experiments conducted by Gardner (2002) at IBML and Kau Bay, Wellington Harbour, was used to encompass the broader range of seston conditions found at all eight sites along the South Coast and in Wellington Harbour. This model gave different results from those derived from Model One. Mean estimates of SFG for $P$. canaliculus were lower at all sites, and negative at two Coastal sites (Table 6.8). This is due to the nature of the coefficient for POM in the model which allowed for very little alteration in $\mathrm{CR}_{\mathrm{s}}$ over a range of seston regimes, and the very low AE values derived from the model (mean $\pm S D, 0.032 \pm 0.069$ ). Model Two of SFG for A. maoriana shows similar results as those for P. canaliculus. There is no evidence of food limitation and very little difference between SFG observations between Harbour and Coastal sites (Fig. 6.9). As with P. canaliculus this is to some extent related to the narrow range of $\mathrm{CR}_{\mathrm{s}}$ (mean $\pm \mathrm{SD}, 2.29 \pm 0.29$ ) and $\mathrm{AE}$ (mean \pm SD, $0.164 \pm 0.075$ ) generated by the model. For Model Two, $M$. galloprovincialis shows some evidence of food limitation at Coastal sites with negative or very low SFG. There is also a trend toward higher SFG at Harbour sites compared to Coastal sites. However, as with P. canaliculus and A. maoriana, there is 
not much variation within $\mathrm{CR}_{\mathrm{s}}$ (mean $\left.\pm \mathrm{SD}, 2.98 \pm 0.031\right)$ and $\mathrm{AE}(0.026 \pm 0.09)$ values predicted by the model.

Both Model One and Model Two predicted lower SFG in the winter at all sites. Periods of 4-5 months of negative SFG were observed regularly at Coastal sites, but rarely at Harbour sites. Such periods of negative SFG can be survived if mussels are of sufficiently good condition to enable utilisation of body reserves (Bayne \& Widdows, 1978). However, experiments in Chapter Four indicate that mussels feeding on ambient Cook Strait water were losing condition when compared to those in Wellington Harbour. Cook Strait water appears to be inadequate for the accumulation of sufficient body reserves to enable survival during periods of low seston quality.

The feeding experiments in Chapter Five suggest that food limitation is occurring, at least some of the time, in A. maoriana and M. galloprovincialis. To some extent, both models in this study show similar evidence of food limitation in all three species. Model One predicts negative SFG at Coastal sites in A. maoriana, Model Two predicts negative SFG at Coastal sites in P. canaliculus and M. galloprovincialis. Both models predict lower SFG at Coastal sites than Harbour sites for all three species. The difference in estimated SFG among sites for A. maoriana using Model Two is less apparent than for any of the other simulations.

The extent of disagreement between these models may to some extent be due to the narrow range of seston conditions under which the Model One was produced. Model One is essentially a low seston model, while Model Two was constructed over a broader range of seston conditions. Food limitation is known to alter feeding behaviour in mussels (see Chapter Five). As a result, models based on data collected under such conditions may be unreliable as observations of the components of SFG have been seen to vary widely under conditions of potential food limitation (Chapter Five). These data indicate that caution must be exercised when applying bioenergetic models. Unless they are based on a large number of observations of feeding behaviour, over a broad range of seston regimes, they will fail to predict accurately the required parameters. 
Obviously models will be improved with additional experimental observations. Subsequent models may benefit from the combination of data in this study with feeding experiments conducted recently at IBML and Kau Bay (Bell, 1997; Gardner, 2000; Gardner 2001; Gardner \& Thompson, 2001). In addition to this, long-term data describing seston characteristics from a number of sites in Wellington Harbour and the South Coast will help to determine the temporal variability in Cook Strait seston. This will provide better information about the length of time that mussels experience negative SFG, and consequently aid in our understanding of why mussels are absent from Wellington's South Coast. 


\section{CHAPTER SEVEN}

\section{Overview}

\section{The Study in Perspective}

The aim of this study has been to identify the possible reason or reasons for the discontinuous distribution of $P$. canaliculus, A. maoriana and M. galloprovincialis around the Wellington region, and specifically the absence of these species from Wellington's South Coast.

Various aspects of mussel ecology were investigated to answer the question and confirming the presence of mussel larvae in the plankton and their ability to settle was an important first step. Mussel larvae were found in plankton samples at both Harbour and Coastal sites, and peak densities in Wellington Harbour and Island Bay were observed in the spring and summer as reported for other mussel species in England (Dare, 1976) and NW Spain (Cáceres-Martínez et al., 1993). Larval densities were approximately an order of magnitude greater within Wellington Harbour compared to Coastal sites, the impact of which is difficult to assess because comparisons with other sites must account for a number of other contributing factors such as local hydrological conditions and proximity to parent populations. However, as mussels were observed to have settled successfully onto artificial substrates at both Harbour and Coastal sites, lower larval density on the Coast in unlikely to be contributing significantly to the observed anomalous distribution. Similar observations of settlement by $P$. canaliculus were made in the Marlborough Sounds (MeredythYoung \& Jenkins, 1978) and by Mytilus edulis aoteanus (=M. galloprovincialis) in Wellington Harbour (Ralph \& Hurley, 1952).

Water sampling at Harbour and Coastal sites confirmed the opinion of Booth (1975) that the Harbour and Cook Strait systems are partially isolated. Characteristics of water samples taken during this study indicated that Harbour water was generally more nutrient rich compared to Cook Strait and typical of a temperate harbour. In contrast, Cook Strait was found to be nutrient poor compared to typical coastal systems. Chlorophyll $a$, percent organic matter, percent $\mathrm{C}$ and percent $\mathrm{N}$, were all low 
compared to similar temperate environments (Berry \& Schleyer, 1983; Bayne et al., 1984; Page \& Ricard, 1990; Navarro et al., 1992). A gradient effect between Harbour and Coastal sites was evident in some of the water characteristics and is analogous to the findings of Hickman et al. (1991) for chlorophyhll a concentrations in PelorusKenepuru Sound.

The extent to which differences in water quality were affecting the distributions of mussels on the South Coast was subsequently investigated using two experimental approaches. A somatic condition index described by Hickman \& Illingworth (1980) was utilised to compare mussels from the Harbour with those from the same population that were translocated to the Island Bay Marine Laboratory (IBML) and fed on ambient Cook Strait water. The condition of Harbour mussels was similar to the results published by Hickman \& Illingworth (1980) and Anderlini (1989) for $P$. canaliculus. However, all three species held at IBML had significantly lower indices when compared to those from Wellington Harbour. In addition to this, mortality of mussels at IBML was very high, particularly for $P$. canaliculus and $M$. galloprovincialis. No corresponding estimate of mortality was measured for either of these species from the Harbour population. However, levels of mortality comparable to those of mussels at IBML are only found in extremely unfavourable environmental conditions such as high pollution levels and heat stress (Cheung, 1993; Tremblay, 1998); neither of which occur in Wellington Harbour. To corroborate these findings, a biochemical condition index was employed. This index compared the ratio of RNA to DNA in mantle edge tissue between Harbour mussels and those transported and held at IBML for 10 weeks. The use of this technique in bivalves has largely been confined to validation under controlled laboratory conditions (Wright \& Hetzel, 1985; Kenchington, 1994). The RNA:DNA ratio is a relatively new and more stresssensitive index than the somatic index and is not known to have been used to test such an hypothesis in mussels. The ratio of RNA to DNA was significantly lower in mussels held at IBML compared with those from the Harbour. This result provides a valuable confirmation of the somatic condition index results and suggests that this technique could be used for similar short-term assessments of mussel stress.

The second experimental approach to assess the influence of water quality on the mussel distribution was a study of the scope for growth (SFG) of each mussel species 
at IBML. These experiments estimated the amount of energy available to mussels after basic metabolic costs are met. Scope for growth varied greatly both within and among each species (P. canaliculus, A. maoriana and M. galloprovincialis) and while results were not consistently negative, they did indicate that periods existed where energy demands were greater than could be met from feeding on Cook Strait water. Similar work conducted on all three species by Gardner (2000) and on P. canaliculus by Gardner \& Thompson (2001) found SFG to be more consistently negative for all three species at IBML than was evident from my study. However, the work of Gardner \& Thompson (2001) was conducted at low levels of food quality and quantity. It is my opinion that although SFG may be positive for periods of several months at IBML, the condition indices indicate that mussels are not able to build up significant energy reserves (in the form of soma or gonad) to sustain them through periods of low seston quality.

Bioenergetic models were derived from the SFG experiments and from the work of Gardner (2002). These models used the water sampling data from eight Harbour and Coastal sites to estimate SFG at each site throughout the year. Both models consistently predicted higher SFG at Harbour sites compared to Coastal sites, SFG at Coastal sites was not always positive. The accuracy of future models would benefit from the inclusion of all feeding work conducted in Harbour and Coastal waters by workers such as Bell (1997), Gardner (2000) and Gardner \& Thompson (2001).

In summary, the most likely reason for the absence of mussels from Wellington's South Coast is a nutrient deficiency in Cook Strait water. At times when SFG is positive, seston quality is inadequate for mussels to acquire the nutrient storage necessary to sustain them through extended periods negative SFG.

\section{Additional considerations}

Wave exposure is unlikely to have any significant influence on the distribution of mussels. While the Harbour is reasonably sheltered compared to the South Coast, there are many areas along the Coast where the reef is quite broad. Here the outer reef dissipates the majority of the wave energy in high seas before it reaches the reef area behind which there are many relatively quiescent pools and lagoon areas within which the effect of wave energy is minimal, even in the roughest seas. 
Predation is not likely to be a factor contributing to the absence of mussels on the South Coast. For three species to be eradicated from such a large area of coastline through predation would be quite remarkable. This would also require the presence of a large population of predators, which are not present on this coastline in numbers sufficient to suggest this (pers. obs.). In the event of high predation pressure, one would also expect to see individuals surviving in refuges such as cracks and crevices, but this occurs very rarely.

\section{Future work}

Further studies of the feeding behaviour of mussels exposed to Cook Strait water over a greater variety of seston conditions would provide a better understanding of the influence of diet on the mussel distribution. In addition, such studies would enable the construction of better predictive models of SFG and other feeding parameters.

The comparison of body condition indices and gonad mass could also be extended to cover a calendar year. This would enable a better comparison between populations, especially for gonad mass where present data were inconclusive. Such an experiment would require the relocation of large numbers of mussels due to inherently high mortality apparent from this study.

There is also ample opportunity to study inter-specific competition between the three species. Investigations of spawning and settlement timing and different feeding responses to various seston regimes are just some of the avenues that can be explored. 


\section{References}

Anderlini, V.C. 1989. Pencarrow Sewer Outfall Pollution Assessment Survey; October 1985-September 1987. Final Report submitted to the Hutt Valley Drainage Board, March 1989, Coastal Marine Research Unit Report No. 10, Victoria University of Wellington.

Anderlini, V.C. 1992. The effect of sewage on trace metal concentrations and scope for growth in Mytilus edulis aoteanus and Perna canaliculus from Wellington Harbour, New Zealand. The Science of the Total Environment, 125: 263-288.

Apte, S., Holland, B.S., Godwin, L.S., Gardner, J.P.A. 2000. Jumping ship: a stepping stone event mediating transfer of a non-indigenous species via a potentially unsuitable environment. Biological Invasions, 2: 75-79.

Arar, E.J., Collins, G.B. 1992. In vitro determination of chlorophyll $a$ and phaeophytin $a$ in marine and freshwater phytoplankton by fluorescence. EPA Method 445.0, Environmental monitoring systems laboratory, Office of Research and Development. US Environmental Protection Agency. Cincinnati, OH 45268.

Bayne, B.L. 1964. Primary and secondary settlement in Mytilus edulis L. (Mollusca). Journal of Animal Ecology, 33: 513-523.

Bayne, B.L. 1973. Aspects of the metabolism of Mytilus edulis during starvation. Netherlands Journal of Sea Research, 7: 399-410.

Bayne, B.L. 1980. Growth and production of mussels (Mytilus edulis) from two populations. Marine Ecology Progress Series, 3: 317-328.

Bayne, B.L., Widdows, J. 1978. The physiological ecology of two populations of Mytilus edulis L. Oecologia (Berlin), 37: 137-162.

Bayne, B.L., Newell, R.C. 1983. Physiological energetics of marine molluscs. In: Saleuddin, A.S.M., Wilbur, K.M. (Eds.) The Mollusca, Vol 4, Physiology, Part 1. Academic Press, New York, pp. 407-515.

Bayne, B.L., Hawkins A.J.S. 1990. Filter-feeding in bivalve molluscs: controls on energy balance. In: Animal Nutrition and Transport Processes. 1. Nutrition in Wild and Domestic Animals. Comparative Physiology. Mellinger J. (Ed.). Basel, Karger, 1990. 5: 70-83.

Bayne, B.L., Thompson, R.J., Widdows, J. 1973. Some effects of temperature and food on the rate of oxygen consumption by Mytilus edulis L. In: Wieser (Ed) Effects of Temperature on Ectothermic Organisms. Springer-Verlag, Berlin, p.191193. 
Bayne, B.L., Widdows, J., Thompson, R.J. 1976. Physiological integrations. In: Bayne, B.L. (Ed.) Marine Mussels. Cambridge University Press, Cambridge, pp. 261-291.

Bayne, B.L., Klumpp, D.W., Clarke, K.R. 1984. Aspects of feeding, including estimates of gut residence time, in three mytilid species (Bivalvia, Mollusca) at two contrasting sites in the Cape Peninsula, South Africa. Oecologia (Berlin) 64: 2633.

Bayne, B.L., Hawkins A.J.S. \& Navarro, E. 1987. Feeding and digestion by the mussel Mytilus edulis L. (Bivalvia: Mollusca) in mixtures of silt and algal cells at low concentrations. Journal of Experimental Marine Biology and Ecology, 111: 122.

Bayne, B.L., Hawkins A.J.S., Navarro, E. 1988. Feeding and digestion in suspensionfeeding bivalve molluscs: the relevance of physiological compensations. From Mechanisms of Physiological Compensation in Intertidal Animals presented at the annual meeting of the American Society of Zoologists, Dec 27-30 1985, Baltimore, Maryland.

Bayne, B.L., Holland, D.L., Moore, M.N., Lowe, D.M., Widdows, J. 1978. Further studies on the effects of stress in the adult and on the eggs of Mytilus edulis. Journal of the Marine Biological Association, 58: 825-842.

Bayne, B.L., Bubel, A., Gabbott, P.A., Livingstone, D.R., Lowe, D.M., Moore, M.N. 1982. Glycogen utilisation and gametogenesis in Mytilus edulis L. Marine Biology, 3: 89-105.

Bayne, B.L., Iglesias, J.I.P., Hawkins, A.J.S., Navarro, E., Héral, M., Deslouspaoli, J.M. 1993. Feeding behaviour of the mussel Mytilus edulis - responses to variations in quantity of organic content of the seston. Journal of the Marine Biological Association of the United Kingdom, 73(4): 813-829.

Bell, N. 1997. The Physiological energetics of the Greenshell Mussel Perna canaliculus. Unpublished BSc (Hons) Project. Victoria University of Wellington.

Berry, P.F., Schleyer, M.H. 1983. The brown mussel Perna perna on the Natal coast, South Africa: ultilization of available food and energy budget. Marine Ecology Progress Series, 13: 201-210.

Bierbaum, R.M., Ferson, S. 1986. Do symbiotic pea crabs decrease growth rate in mussels? Biological Bulletin, 170: 51-61.

Booth, J.D. 1975. Seasonal and tidal variations in the hydrology of Wellington Harbour. New Zealand Journal of Marine and Freshwater Research, 9(3): 333354.

Booth, J.D. 1977. Common bivalve larvae from New Zealand: Mytilacea. New Zealand Journal of Marine and Freshwater Research, 11 (3): 407-440. 
Bowman, M.J., Kibblewhite, A.C., Murtagh, R.A., Chiswell, S.M., Sanderson, B.G. 1983. Circulation and mixing in greater Cook Strait, New Zealand. Oceanologia Acta, 6(4): 383-391.

Bricelj, V.M., Malhouf, R.E, 1984. Influence of algal and suspended sediment concentrations on the feeding physiology of the hard clam Mercenaria mercenaria. Marine Biology, 84: 155-165.

Buchanan, S., Babcock, R. 1997. Primary and secondary settlement by the greenshell mussel Perna canaliculus. Journal of Shellfish Research, 16(1): 71-76.

Butman, C.A. 1987. Larval settlement of soft-sediment invertebrates: the spatial scales of pattern explained by active habitat selection and the emerging role of hydrodynamical processes, pp. 113-165. In: Oceanography and Marine Biology Annual Review, 25: 113-165. Barnes, M.A. (Ed.), Aberdeen University Press.

Cáceres-Martínez, J., Figueras, A. 1998. Distribution and abundance of mussel (Mytilus galloprovincialis Lmk) larvae and post-larvae in the Ria de Vigo (NW Spain). Journal of Experimental Marine Biology and Ecology, 229(2): 277-287.

Cáceres-Martínez, J., Robledo, J.A., Figueras, A. 1993. Settlement of mussels Mytilus galloprovincialis on an exposed rocky shore in Ria de Vigo, NW Spain. Marine Ecology Progress Series, 93: 195-198.

Campbell, D.E., Newell, C.R. 1998. MUSMOD ${ }^{\circledR}$, a production model for bottom culture of the blue mussel, Mytilus edulis L. Journal of Experimental Marine Biology and Ecology, 219: 171-203.

Ceccherelli, V.U., Barboni, A. 1983. Growth, survival and yield of Mytilus galloprovincialis Lamk. on fixed suspended culture in the bay of the Po River delta. Aquaculture, 34: 101-114.

Chaparro, O.R., Winter, J.E. 1983. The effect of winter period, gametogenesis and spawning on the calorific content of soft parts in Mytilus chilensis. Aquaculture, 32: 419-422.

Cheung, S.G. 1993. Population and energy budgets of green-lipped mussel Perna viridis (Linnaeus) in a polluted harbour. Journal of Experimental Marine Biology and Ecology, 168: 1-24.

Chícharo, A.M. 1998. Nutritional condition and starvation in Sadina pilchardus (L.) larvae off southern Portugal compared with some environmental factors. Journal of Experimental Marine Biology and Ecology, 225: 123-137.

Chícharo, L.M.Z., Chícharo, M.A.A.T. 1995. The DNA/RNA ratio as a useful indicator of the nutritional condition in juveniles of Ruditapes decussatus. Scentia Marina, 59(1): 95-101.

Chipperfield, P.N.J. 1953. Observations of the Breeding and Settlement of Mytilus edulis (L.) in British Waters. Journal of the Marine Biological Association of the United Kingdom, 32: 449-476. 
Clarke, A., Rodhouse, P.G., Holmes, L.J., Pascoe, P.L. 1989. Growth rate and nucleic acid ratio in cultured cuttlefish Sepia officinalis (Mollusca: Cephalopoda). Journal of Experimental Marine Biology and Ecology, 133: 229-240.

Clemmesen, C.M., 1987. Laboratory studies on RNA/DNA ratios of starved and fed herring (Clupea harengus) and turbot (Scophthalmus maximus) larvae. Conseil International pour l'Exploration de la Mer, 43: 122-128.

Clemmesen, C.M., 1988. A RNA and DNA fluorescence technique to evaluate the nutritional condition of individual marine fish larvae. Meeresforsch, 32: 134-143.

Clemmesen, C.M., 1994. The effect of food availability, age or size on the RNA/DNA ratio of individually measured herring larvae: laboratory calibration. Marine Biology, 118: 377-382.

Conover, R.J. 1966. Assimilation of organic matter by zooplankton. Limnology and Oceanography, 11: 338-345.

Cranford, P.J., Gordon Jr, D.C. 1992. The influence of dilute clay suspensions on sea scallop (Placopecten magellanicus) feeding activity and tissue growth. Netherlands Journal of Sea Research, 30: 107-120.

Cranford, P.J., Hill, P.S. 1999. Seasonal variation in food utilisation by the suspension feeding bivalve molluscs Mytilus edulis and Placopecten magellanicus. Marine Ecology Progress Series, 190: 223-239.

Dare, P.J. 1976. Settlement, growth and production of the mussel, Mytilus edulis L., in Morecambe Bay, England. Fishery Investigations, Series II, 28(1): 1-25.

Davenport, J., Chen, X. 1987. A comparison of methods for the assessment of condition in the mussel (Mytilus edulis L.). Journal of Molluscan Studies, 53: 293297.

Davids, C. 1964. The influence of suspensions of micro-organisms of different concentrations on the pumping and retention of food by the mussel (Mytilus edulis L.). Netherlands Journal of Sea Research, 2: 233-249.

Denis, L., Alliot, E., Grzebyk, D. 1999. Clearance rate responses of Mediterranean mussel, M. galloprovincialis, to variations in the flow, water temperature, food quality and quantity. Aquatic Living Resources, 12(4): 279-288.

Dorgelo, J., Kraak, M.H.S. 1993. Seasonal variation in tissue dry biomass and its relative ash and organic carbon and nitrogen content in the freshwater mussel Dreissena polymorpha (Pallas). Archiv fur hydrobiologie, 127(4): 409-421.

Dortch, Q., Roberts, T.L., Clayton Jr, J.R., \& Ahmed, S.I. 1983. RNA/DNA ratios and DNA concentrations as indicators of growth rate and biomass in planktonic marine organisms. Marine Ecology Progress Series, 13: 61-71. 
Doyle, R.W. 1974. Choosing between darkness and light: the ecological genetics of photic behaviour in the plankton larvae of Spirorbis borealis. Marine Biology, 25: 311-317.

Emmett, B., Thompson, K., Popham, J.D. 1987. The reproductive and energy storage cycles of two populations of Mytilus edulis (Linne) from British Columbia. Journal of Shellfish Research, 6(1): 29-36.

Esteves, E., Chícharo, M.A., Pina, T., Coelho, M.L., Andrade, J.P. 2000. Comparison of RNA/DNA ratios obtained with two methods for nucleic acid quantification in gobiid larvae. Journal of Experimental Marine Biology and Ecology, 245: 43-55.

Foster-Smith, R.L. 1975. The effect of concentration of suspension and inert material on the assimilation of algae by three bivalves. Journal of the Marine Biological Association of the United Kingdom, 55: 411-418.

Folkvord, A., Ystanes, L., Johannessen, A. Moksness, E. 1996. RNA: DNA ratios and growth of herring (Clupea harengus) larvae reared in mesocosms. Marine Biology, 126: $591-602$.

Frechette, M., Bacher, C. 1998. A modelling study of optimal stocking density of mussel populations kept in experimental tanks. Journal of Experimental Marine Biology and Ecology, 219: 241-255.

Gardner, J.P.A. 2000. Where are the mussels on Cook Strait (New Zealand) shores? Low seston quality as a possible factor limiting multi-species distributions. Marine Ecology Progress Series, 194: 123-132.

Gardner, J.P.A. 2002. Effects of seston variability on the clearance rate and absorption efficiency of the mussels Aulacomya maoriana, Mytilus galloprovincialis and Perna canaliculus from New Zealand. Journal of Experimental Marine Biology and Ecology. In press.

Gardner, J.P.A., Kathiravetpillai, G. 1997. Biochemical genetic variation at a leucine aminopeptidase (LAP) locus in blue (Mytilus galloprovincialis) and greenshell (Perna canaliculus) mussel populations along a salinity gradient. Marine Biology, 128: 619-625.

Gardner, J.P.A., Thompson, R.J. 2001. Naturally low seston concentration and the net energy balance of the greenshell mussel, (Perna canaliculus) at Island Bay, Cook Strait, New Zealand. New Zealand Journal of Marine and Freshwater Research, 35: 457-468.

Gibbs, M.M., Vant, W.N. 1998. Seasonal changes in factors controlling phytoplankton growth in Beatrix Bay, New Zealand. New Zealand Journal of Marine and Freshwater Research, 31: 237-248.

Gibbs, M.M., Pickmere, S.E., Woods, P.H., Paynes, G.W., James, M.R., Hickman, R.W., Illingworth, J. 1992. Nutrient and chlorophyll $a$ variability at six stations associated with mussel farming in Pelorus Sound, 1984-85. New Zealand Journal of Marine and Freshwater Research, 26: 197-211. 
Gilmore, A.E. 1960. The hydrology of Cook Strait and Wellington Harbour. In: O’Conner (Ed.). Science in Wellington, Royal Society of New Zealand, p. 40.

Granby, K., Spliid, N.H. 1995. Hydrocarbons and organochlorines in common mussels from the Kattegat and The Belts and their relation to condition indices. Marine Pollution Bulletin, 30(1): 74-82.

Grant, J. 1996. The relationship of bioenergetics and the environment to the field of cultured bivalves. Journal of Experimental Marine Biology and Ecology, 200: 239256.

Grant, J., Bacher, C. 1998. Comparative models of mussel bioenergetics and their validation at field culture sites. Journal of Experimental Marine Biology and Ecology, 219: 21-44.

Griffiths, R.J. 1980. Natural food availability and assimilation in the bivalve Choromytilus meridionalis. Marine Ecology Progress Series, 3: 151-156.

Griffiths, C.L., King, J.A. 1979. Some relationships between size, food availability and energy balance in the ribbed mussel Aulacomya ater. Marine Biology, 51: 141149.

Grønkjær, P., Clemmesen, C., St. John, M. 1997. Nutritional condition and vertical distribution of Baltic cod larvae. Journal of Fish Biology, 51: 352-369.

Hadfield, A.J., Anderson, D.T. 1988. Reproductive cycles of the bivalve molluscs Anadara trapezia (Deshayes), Venerupis crenata Lamarck and Anomia descripta Iredale in the Sydney Region. Australian Journal of Marine and Freshwater Research, 39: 649-660.

Haines, C.M.C., Edmunds, M., Pewsey, A.R. 1994. The pea crab, Pinnotheres pisum (Linnaeus, 1767), and its association with the common mussel, Mytilus edulis (Linnaeus, 1758), in the Solent, UK. Journal of Shellfish Research, 13(1): 5-10.

Hawkins, A.J.S., Bayne, B.L. 1984. Seasonal variation in the balance between physiological mechanisms of feeding and digestion in Mytilus edulis (Bivalvia: Mollusca). Marine Biology, 82: 233-240.

Hawkins, A.J.S., Bayne, B.L. 1992. Physiological Interrelations, and the Regulation of Production, pp. 171-221. In: Gosling, E. (Ed.), The Mussel Mytilus: Ecology, Physiology, Genetics and Culture. Elsevier, 1992, p. 589.

Hawkins, A.J.S., Navarro, E., Iglesias, J.I.P. 1990. Comparative allometries of gut passage time, gut content and metabolic faecal loss in Mytilus edulis and Cerastoderma edule. Marine Biology, 105: 197-204.

Hawkins, A.J.S., Smith, R.F.M., Bayne, B.L., Heral, M. 1996. Novel observations underlying the fast growth of suspension-feeding shellfish in turbid environments. Marine Ecology Progress Series, 131(1-3): 179-190. 
Hawkins, A.J.S., James, M.R., Hickman, R.W., Hatton, S., Weatherhead, M. 1999. Modelling of suspension-feeding and growth in the green-lipped mussel Perna canaliculus exposed to natural and experimental variations of seston availability in the Marlborough Sounds, New Zealand. Marine Ecology Progress Series, 191: 217-323.

Hayden, B.J., Kendrick, T.H. 1992. Predicting the settlement of greenshell mussels, Perna canaliculus, from the abundance of larvae, pp. 137-143. In: Proceedings of the Second International Temperate Reef Symposium, 7-10 January 1992, Auckland, New Zealand. Battershill, C.N. et al. (Eds.). NIWA Marine, Wellington, p. 252.

Heath, R.A. 1971. Hydrology and circulation in central and southern Cook Strait, New Zealand. New Zealand Journal of Marine and Freshwater Research, 5(1): 178-199.

Heath, R.A. 1977. Circulation and hydrology of Wellington Harbour. New Zealand Oceanographic Survey, No. 12, p. 8.

Hickman, R.W. 1978. Incidence of pea crab and a trematode in cultivated and natural green-lipped mussels. New Zealand Journal of Marine and Freshwater Research, 12(2): 211-215.

Hickman, R.W., Illingworth, J. 1980. Condition Cycle of the Green-Lipped Mussel Perna canaliculus in New Zealand. Marine Biology, 60: 27-38.

Hickman, R.W., Waite, R.P., Illingworth, J., Meredyth-Young, J.L., Payne, G. 1991. The relationship between farmed mussels Perna canaliculus, and available food in Pelorus-Kenepuru Sound, New Zealand, 1983-1985. Aquaculture, 99: 49-68.

Himmelman, J.H. 1981. Synchronization of spawning in marine invertebrates by phytoplankton. Advances in Invertebrate Reproduction, 2: 3-19.

Incze, L.S., Lutz, R.A., Watling, L. 1980. Relationships between effects of environmental temperature and seston on growth and mortality of Mytilus edulis in a temperate northern estuary. Marine Biology, 54: 147-156.

James, M.R., Weatherhead, M.A., Ross, A.H. 2001. Size-specific clearance, excretion, and respiration rates, and phytoplankton selectivity for the mussel $P$. canaliculus at low levels of natural food. New Zealand Journal of Marine and Freshwater Research, 35: 74-86.

Jeffs, A.G., Holland, R.C., Hooker, S.H., Hayden, B.J. 1999. Overview and bibliography of research on the greenshell mussel, Perna canaliculus, from New Zealand waters. Journal of Shellfish Research, 18(2): 347-360.

Jones, J.B. 1975. Studies of animals closely associated with some New Zealand marine shellfish. Unpublished PhD thesis, Victoria University of Wellington.

Jones, J.B. 1977. Natural history of the pea crab in Wellington Harbour, New Zealand. New Zealand Journal of Marine and Freshwater Research, 11: 667-676. 
Jørgensen, C.B. 1966. The Biology of suspension feeding. Pergamon Press, Oxford p. 357.

Kautsky, N. 1982a. Growth and size structure in a Baltic Mytilus edulis population. Marine Biology, 68: 117-133.

Kautsky, N. 1982b. Quantitative studies on gonad cycle, fecundity, reproductive output and recruitment in a Baltic Mytilus edulis population. Marine Biology, 68: 143-160.

Kawakami, Y., Mochioka, N., Kimura, R., Nakazono, A. 1999. Seasonal changes of the RNA/DNA ratio, size and lipid contents and immigration adaptability of Japanese glass-eels, Anguilla japonica, collected in northern Kyushu, Japan. Journal of Experimental Marine Biology and Ecology, 238: 1-19.

Kenchington, E.L.R. 1994. Spatial and temporal variation in adductor muscle RNA/DNA ratio in the sea scallops (Placopecten magellanicus) in the Bay of Funday, Canada. Journal of Shellfish Research, 13(1): 19-24.

Kennedy, V.S. 1977. Reproduction in Mytilus edulis aoteanus and Aulacomya maoriana (Mollusca: Bivalvia) from Taylors Mistake, New Zealand. New Zealand Journal of Marine and Freshwater Research, 11(2): 255-267.

King, P.A., McGrath, D., Britton, W. 1990. The use of artificial substrates in monitoring mussel (Mytilus edulis L.) settlement on an exposed rocky shore in the west of Ireland. Journal of the Marine Biological Association of the United Kingdom, 70: 371-380.

Kiørboe, T., Møhlenberg, F., Nohr, O. 1980. Feeding, particle selection and carbon absorption in Mytilus edulis in different mixtures of algae and resuspended bottom material. Ohpelia, 19: 193-205.

Kiørboe, T., Møhlenberg, F., Nohr, O. 1981. Effect of suspended bottom material on growth and energetics in Mytilus edulis. Marine Biology, 61: 283-288.

Lodeiros, C.J.M., Fernández, R.I., Bonmatí. A., Himmelman, J.H., Chung, K.S. 1996. Relation of RNA/DNA ratios to growth for the scallop Euvola (Pecten) ziczac in suspended culture. Marine Biology, 126: 245-251.

Lutz, R.A. \& Kennish, M.J. 1992. Ecology and Morphology of Larval and Early Postlarval Mussels, pp. 53-85. In: Gosling, E. (Ed.) The Mussel Mytilus: Ecology, Physiology and Culture. Elesvier, 1992, p. 589.

McGrath, D., King, P.A., Gosling, E.M. 1988. Evidence for the direct settlement of Mytilus edulis L. larvae on adult mussel beds. Marine Ecology Progress Series, 47: 103-106.

McGrath, D., King, P.A., Reidy, M. 1994. Conditioning of artificial substrata and settlement of the marine mussel Mytilus edulis (L.) - A Field experiment. Biology and Environment - Proceedings of the Royal Irish Academy, 94 B(1): 53-56. 
McGurk, M.D., Warburton, H.D., Galbraith, M., Kusser, W.C. 1992. RNA-DNA ratio of herring and sand lance larvae from Port Moller, Alaska: comparison with prey concentration and temperature. Fisheries Oceanography, 1(3): 193-207.

Marsden, I.D., Weatherhead, M.A. 1998. Effects of aerial exposure on oxygen consumption by the New Zealand mussel Perna canaliculus (Gmelin, 1791) from an intertidal habitat. Journal of Experimental Marine Biology and Ecology, 230: 15-29.

Marsden, I.D., Weatherhead, M.A. 1999. Shore-level induced variations in condition and feeding of the mussel Perna canaliculus from the east coast of the South Island, New Zealand. New Zealand Journal of Marine and Freshwater Research, 33: 611-622.

Maxwell, B.E. 1956. Hydrobiological observations for Wellington Harbour. Transactions of the Royal Society of New Zealand, 83(3): 493-503.

Mayrand, E., Pellerin-Massicotte, J., Vincent, B. 1994. Small scale variability of biochemical indices of growth in Mya arenaria (L.). Journal of Shellfish Research, 13: 119-205.

Meadows, P.S., Campbell, J.I. 1972. Habitat selection by aquatic invertebrates. Advances in Marine Biology, 10: 271-282.

Meredyth-Young, J.L., Jenkins, R.J. 1978. Depth of settlement of two mussel species on suspended collectors in Marlborough Sounds, New Zealand. New Zealand Journal of Marine and Freshwater Research, 12(1): 83-86.

Morton, J., Miller, M. 1968. The New Zealand Sea Shore. Collins, p. 653.

Navarro, E., Iglesias, J.I.P., Ortega M.M. 1992. Natural sediment as a food source for the cockle Cerastoderma edule (L.): effect of variable particle concentration on feeding, digestion and the scope for growth. Journal of Experimental Marine Biology and Ecology, 156: 69-87.

Navarro, E., Iglesias, J.I.P., Perez Camacho, A., Labarta, U., Beiras, R. 1991. The physiological energetics of mussels (Mytilus galloprovincialis Lmk) from different cultivation rafts in the Ria de Arosa (Galicia, N.W. Spain). Aquaculture, 94: 197212.

Newell, C.R., Campbell, D.E., Gallagher, S.M. 1998. Development of the mussel aquaculture lease site model MUSMOD $^{\complement}$ : a field program to calibrate model formulations. Journal of Experimental Marine Biology and Ecology, 219: 143-169.

Newell, R.I.C., Hilbish, T.J., Koehn, R.K., Newell, C.J. 1982. Temporal variation in the reproductive cycle of Mytilus edulis L. (Bivalvia, Mytilidae) from localities on the east coast of the United States. Biological Bulletin, 162: 299-310.

Nuscetti, O., Morales, D. 1988. Crecimiento de algunos tejidos del mejillon Perna perna (L. 1758): composicin de ADN, relaciones ARN/AND y reservas energeticas. Acta cient Venez, 39: 289-293. 
O’Beirn, F.X., Walker, R.L. 1999. Pea Crab, Pinnotheres osteum (Say, 1817), in the eastern oyster, Crassostrea virginica (Gmelin, 1791): Prevalence and apparent adverse effects on oyster gonad development. Veliger, 42(1): 17-20.

Ogilvie, S.C., Ross, A.H., Schiel, D.R. 2000. Phytoplankton biomass associated with mussel farms in Beatrix Bay, New Zealand. Aquaculture, 181: 71-80.

Okumu•, I., Stirling, H.P. 1994. Physiological energetics of cultivated mussel (Mytilus edulis) populations in two Scottish west coast lochs. Marine Biology, 119: 125131.

Page, H.M., Hubbard, D.M. 1987. Temporal and spatial patterns of growth in mussels Mytilus edulis on an offshore platform: relationships to water temperature and food availability. Journal of Experimental Marine Biology and Ecology, 111: 159-179.

Page, H.M., Ricard, Y.O. 1990. Food availability as a limiting factor to mussel Mytilus edulis growth in California coastal waters. Fisheries Bulletin, 88: 677-686.

Paine, R.T. 1974. Intertidal Community Structure: Experimental Studies on the Relationship between a Dominant Competitor and Its Principal Predator. Oecologia, 15: 93-120.

Palmer, P. 1995. Occurrence of a New Zealand pea crab, Pinnotheres novaezelandiae, in five species of surf clam. Marine and Freshwater Research, 46: 1071-1075.

Paon, L.A., Kenchington, E.L.R. 1995. Changes in somatic and reproductive tissues during artificial conditioning of the sea scallop, Placopecten magellanicus (Gmelin, 1791). Journal of Shellfish Research, 14(1): 53-58.

Pawlik, J.R. 1992. Chemical ecology of the settlement of benthic marine invertebrates. In: Oceanography and Marine Biology Annual Review, 30: 273-335. Barnes, M.A., Ansell, A.D.,Gibson, R.N. (Eds.). UCL Press.

Petersen, J.H. 1984. Larval settlement behaviour in competing species: Mytilus californianus Conrad and M. edulis L. Journal of Experimental Marine Biology and Ecology, 82: 147-159.

Pouvreau, S., Bacher, C., Héral, M. 2000. Ecophysiological model of growth and reproduction of the black pearl oyster, Pinctada margaritifera: potential applications for pearl farming in French Polynesia. Aquaculture, 186: 117-144.

Pulfrich, A. 1997. Seasonal variation in the occurrence of planktic bivalve larvae in the Schleswig-Holstein Wadden Sea. Helolander Meeresuntersuchungen, 51(1): 23-39.

Raae, A.J., Opstad, I., Kvenseth, P., Walther, B.T. 1988. RNA, DNA and protein during early development in feeding and starved cod (Gadus morphua L.) larvae. Aquaculture, 73: 247-259. 
Ralph, P.M., Hurley, D.E. 1952. The settling and growth of wharf pile fauna in Port Nicholson, Wellington, New Zealand. Zoology Publications from Victoria University College, 19: 1-22.

Ramirez, S.C., Cáceres-Martínez, J. 1999. Settlement of the blue mussel Mytilus galloprovincialis Lamarck on artificial substrates in Bahia de Todos Santos BC. Mexico. Journal of Shellfish Research, 18(1): 33-39.

Redfearn, P., Chanley, P., Chanley, M. 1986. Larval shell development of four species of New Zealand mussels: (Bivalvia, Mytilacea). New Zealand Journal of Marine and Freshwater Research, 20: 157-172.

Reusch, T.B.H., Williams, S.L. 1999. Macrophyte canopy structure and the success of an invasive marine bivalve. Oikos, 84(3): 398-416.

Rheault, R.B., Rice, M.A. 1996. Food-limited growth and condition index in the Eastern Oyster, Crassostrea virginica (Gmelin, 1791), and the Bay Scallop, Argopecten irradians (Lamark 1819). Journal of Shellfish Research, 15(2): 271283.

Robbins, L., Lubet, P., Besnard, J.Y. 1990. Seasonal variations in the nucleic acid content and RNA:DNA ratio of the gonad of the scallop Pecten maximus. Marine Biology, 105: 191-195.

Robinson, S.M.C., Ware, D.M. 1988. Ontogenetic development of growth rates in larval Pacific herring, Clupea harengus pallasi, measured with RNA-DNA ratios in the Strait of Georgia, British Columbia. Canadian Journal of Fisheries and Aquatic Sciences, 45: 1422-1429.

Rosenberg, R., Loo, L. 1983. Energy flow in a Mytilus edulis culture in western Sweden. Aquaculture, 35: 151-161.

Scheltema, R.S. 1974. Biological interactions determining larval settlement of marine invertebrates. Thalassia Jugoslavica, 10: 263-296.

Seed, R., Suchanek, T.H. 1992. Population and Community Ecology of Mytilus, pp. 87-169. In: Gosling, E. (Ed.) The Mussel Mytilus: Ecology, Physiology and Culture. Elesvier, 1992, p. 589.

Schneider, D.W. 1992. A bioenergetics model of the zebra mussel, Dreissena polymorpha, growth in the Great Lakes. Canadian Journal of Fisheries and Aquatic Sciences, 49: 1406-1416.

Scholten, H., Smaal, A.C. 1998. Responses of Mytilus edulis L. to varying food concentrations: testing EMMY, an ecophysiological model. Journal of Experimental Marine Biology and Ecology, 219: 217-239.

Smith, J.R., Strehlow, D.R. 1983. Algal induced spawning in the marine mussel Mytilus californianus. International Journal of Invertebrate Reproduction, 6: 129133. 
Sprung, M. 1984. Physiological energetics of mussel larvae (Mytilus edulis). I. Shell growth and biomass. Marine Ecology Progress Series, 17: 295-305.

Starr, M., Himmelman, J.H., Therriault, J. 1990. Direct coupling of marine invertebrate spawning with phytoplankton blooms. Science, 247: 1071-1074.

Stephenson, T.A., Stephenson, A. 1949. The universal features of zonation between tidemarks on rocky coasts. Journal of Ecology, 37: 289-305.

Stuart, V. 1982. Absorbed ration, respiratory costs and resultant scope for growth in the mussel Aulacomya ater (Molina) fed on a diet of kelp detritus of different ages. Marine Biology Letters, 3: 289-306.

Soong, K. 1997. Some life history observations on the pea crab, Pinnotheres tsingtaoensis, symbiotic with the bivalve mollusk, Sanguinolaria actuta. Crustaceana, 70(8): 855-866.

Theisen, B.F. 1987. Infestation of Mytilus edulis by Mytilicola intestinalis. Ophelia, 27: 77-86.

Thompson, R. J. 1984. The reproductive cycle and physiological ecology of the mussel Mytilus edulis in a subarctic, non-estuarine environment. Marine Biology, 79: 277-288.

Thompson, R.J., Bayne, B.L. 1972. Active metabolism associated with feeding in the mussel Mytilus edulis L. Journal of Experimental Marine Biology and Ecology, 9: 111-124.

Thompson, R.J., Bayne, B.L. 1974. Some relationships between growth, metabolism and food in the mussel, Mytilus edulis. Marine Biology, 27: 317-326.

Toblado, A., Gappa, J.L. 1995. Host-parasite relationships between the mussel, Mytilus edulis L, and the pea crab, Tumidotheres maculatus (Say), in the south western Atlantic. Journal of Shellfish Research, 14(2): 417-423.

Tracey, M.L., Bellet, N.F., Gravem, C.D. 1975. Excess allozyme homozygosity and breeding population structure in the mussel Mytilus californianus. Marine Biology, 32: 303-311.

Tranter, D.J., Smith, P.E. 1968. Filtration performance. Zooplankton sampling. Monographs on oceanographic methodology 2. UNESCO, Paris, p. 174.

Tremblay, R., Myrand, B., Sevigny, J., Blier, P., Guderley, H. 1998. Bioenergetic and genetic parameters in relation to susceptibility of blue mussels, Mytilus edulis (L.) to summer mortality. Journal of Experimental Marine Biology and Ecology, 221: 27-58.

van Erkom Schurink, C., Griffiths, C.L. 1992. Physiological energetics of four South African mussel species in relation to body size, ration and temperature. Comparative Biochemistry and Physiology, 101A(4): 779-789. 
Widdows, J. 1973. The effects of temperature on the metabolism and activity of Mytilus edulis. Netherlands Journal of Sea Research, 7: 387-398.

Widdows, J. 1978. Combined effects of body size, food concentration and season on the physiology of Mytilus edulis. Journal of the Marine Biological Association of the United Kingdom, 58: 109-124.

Widdows, J., Bayne, B.L. 1971. Temperature acclimation of Mytilus edulis with reference to its energy budget. Journal of the Marine Biological Association of the United Kingdom, 51: 827-843.

Widdows, J., Johnson, D. 1988. Physiological energetics of Mytilus edulis: Scope for Growth. Marine Ecology Progress Series, 46: 113-121.

Widdows, J., Donkin, P. 1992. Mussels and Environmental Contaminants: Bioaccumulation and Physiological aspects, pp. 383-423. In: Gosling, E. (Ed.) The Mussel Mytilus: Ecology, Physiology, Genetics and Culture. Elsevier Press, 1992, p. 589.

Widdows, J., Fieth, P., Worrall, C.M. 1979. Relationships between seston, available food and the feeding activity of the common mussel Mytilus edulis. Marine Biology, 50: 195-207.

Wilson, B.R., Hodgkin, E.P. 1967. A comparative account of the reproductive cycles of five species of marine mussels (Bivalvia: Mytilidae) in the vicinity of Freemantle, Western Australia. Australian Journal of Marine and Freshwater Research, 18: 175-203.

Winter, J.E. 1973. The filtration rate of Mytilus edulis and its dependence on algal concentration, measured by continuous recording apparatus. Marine Biology, 22: 317-328.

Winter, J.E. 1976. Feeding experiments with Mytilus edulis L. at small laboratory scale. II. The influence of suspended silt in addition to algal suspensions on growth, pp. 583-600. In: Persoone, G., Jaspers, E. (Eds.). Research in mariculture at laboratory and pilot scale, Vol. 1. 10 ${ }^{\text {th }}$ European Marine Biology Symposium. Univers Press, Wettersen.

Wong, W.H., Cheung, S.G. 1999. Feeding behaviour of the green mussel Perna viridis (L.): Responses to variation in seston quantity and quality. Journal of Experimental Marine Biology and Ecology, 236(2): 191-207.

Worrall, C.M., Widdows, J. 1984. Investigation of factors influencing mortality in Mytilus edulis L. Marine Biology Letters, 5: 85-97.

Wright, D.A., Hetzel, E.W. 1985. Use of RNA:DNA ratios as an indicator of nutritional stress in an American oyster Crassostrea virginica. Marine Ecology Progress Series, 25: 199-206. 
Zandee, D.I., Kluytmans, J.H., Zyrburg, W., Pieters, H. 1980. Seasonal variations in biochemical composition of Mytilus edulis with reference to energy metabolism and gametogenesis. Netherlands Journal of Sea Research, 14(1): 1-29. 
Appendices 

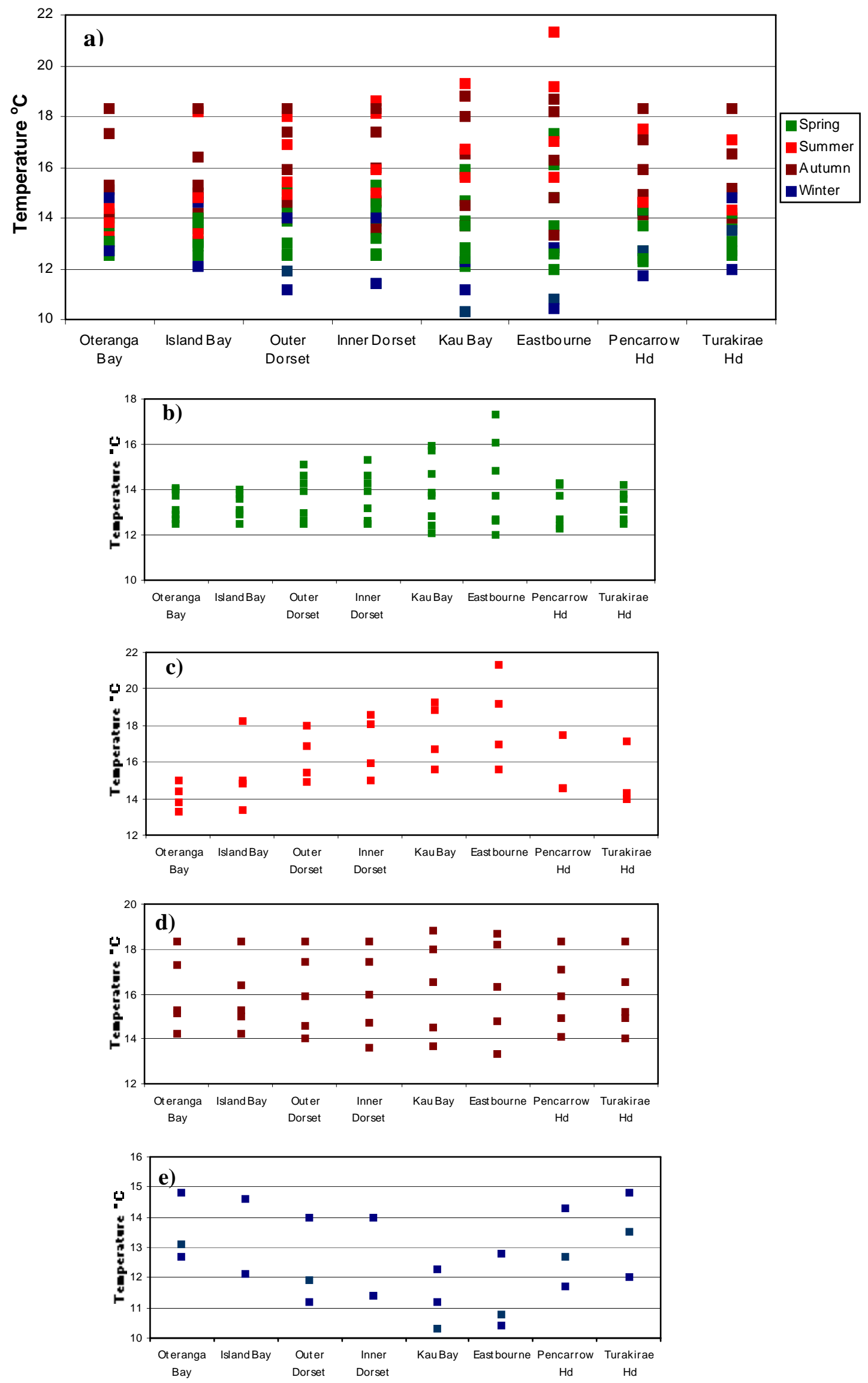

Appendix A1. Water temperature at all sites and seasons: a) all data, b) spring, c) summer, d) autumn, e) winter. 

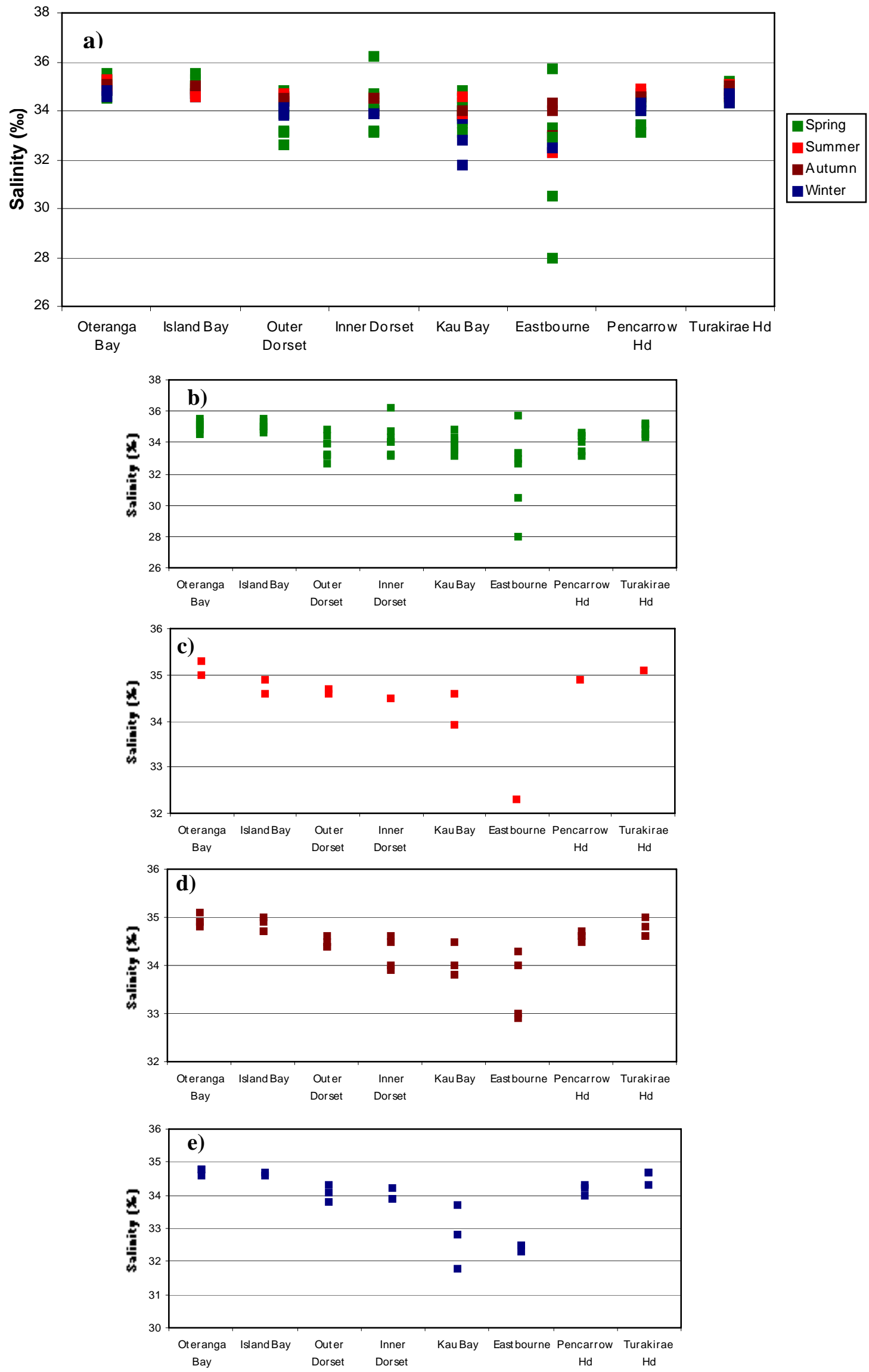

Appendix A2. Salinity at all sites and seasons: a) all data, b) spring, c) summer, d) autumn, e) winter. 


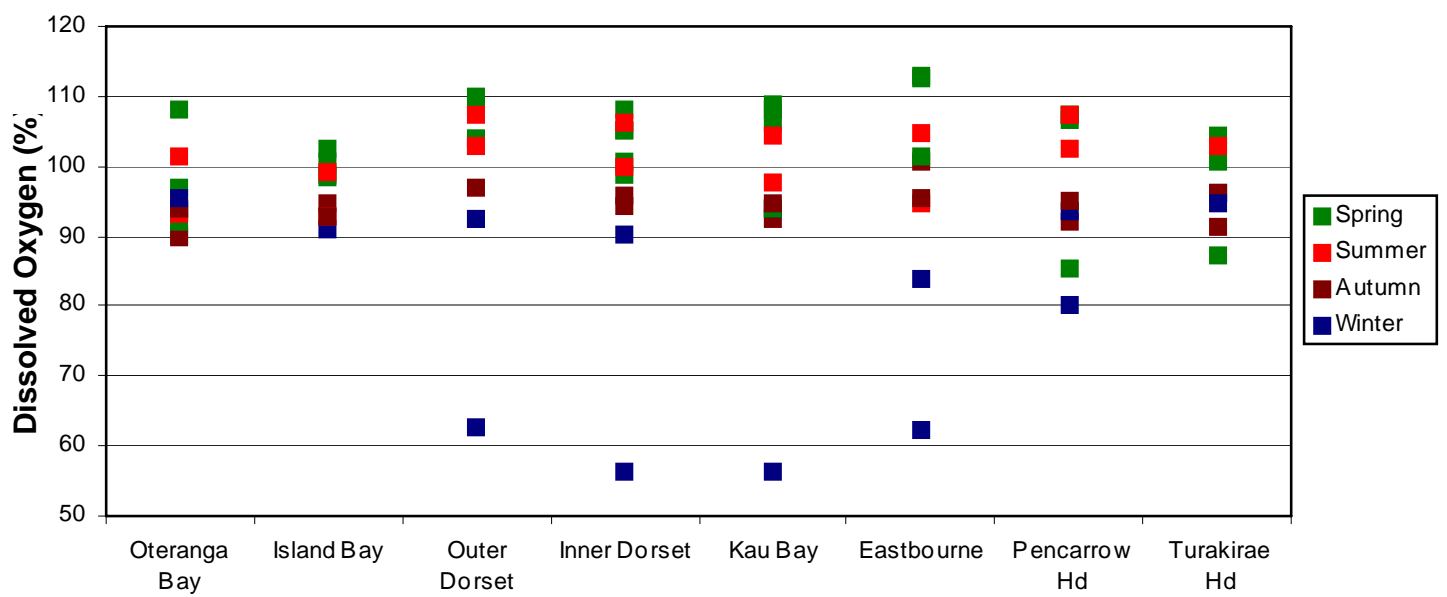

Appendix A3. Dissolved Oxygen at all sites and seasons. 

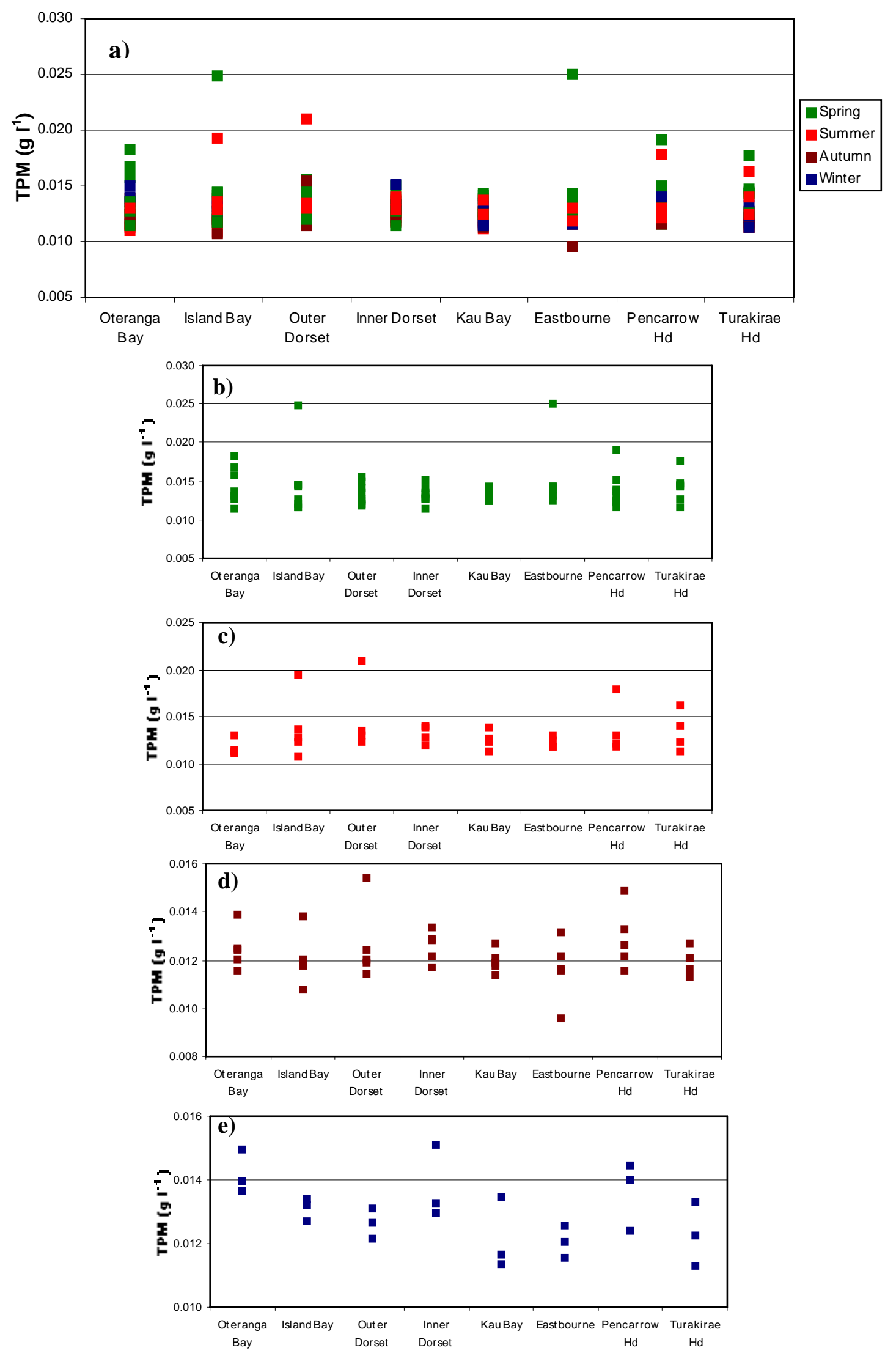

Appendix A4. Total particulate matter (TPM) at all sites and seasons: a) all data, b) spring, c) summer, d) autumn, e) winter. 

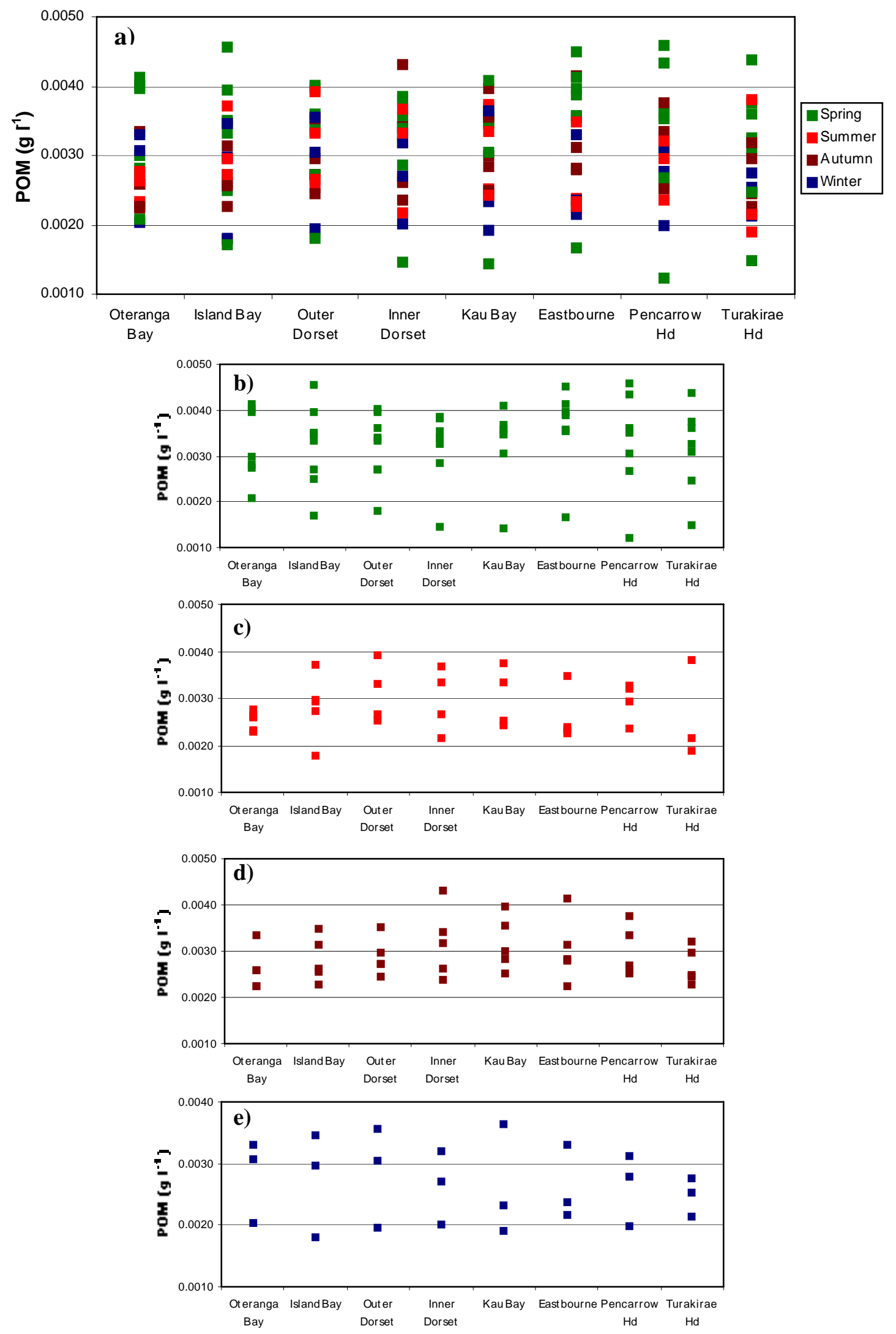

Appendix A5. Particulate organic matter (POM) at all sites and seasons: a) all data, b) spring, c) summer, d) autumn, e) winter. 

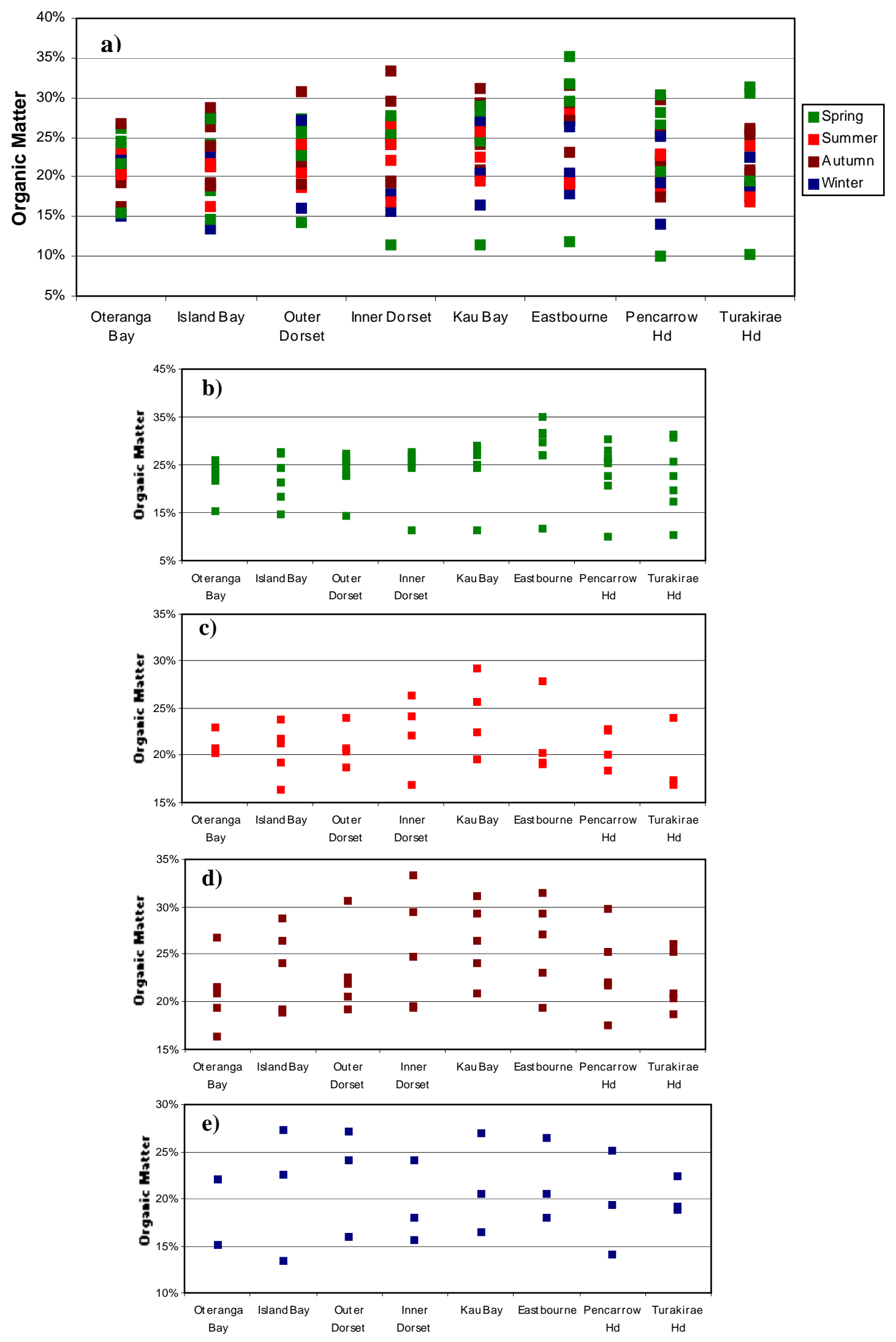

Appendix A6. Percent organic matter at all sites in all seasons: a) all data, b) spring, c) summer, d) autumn, e) winter. 

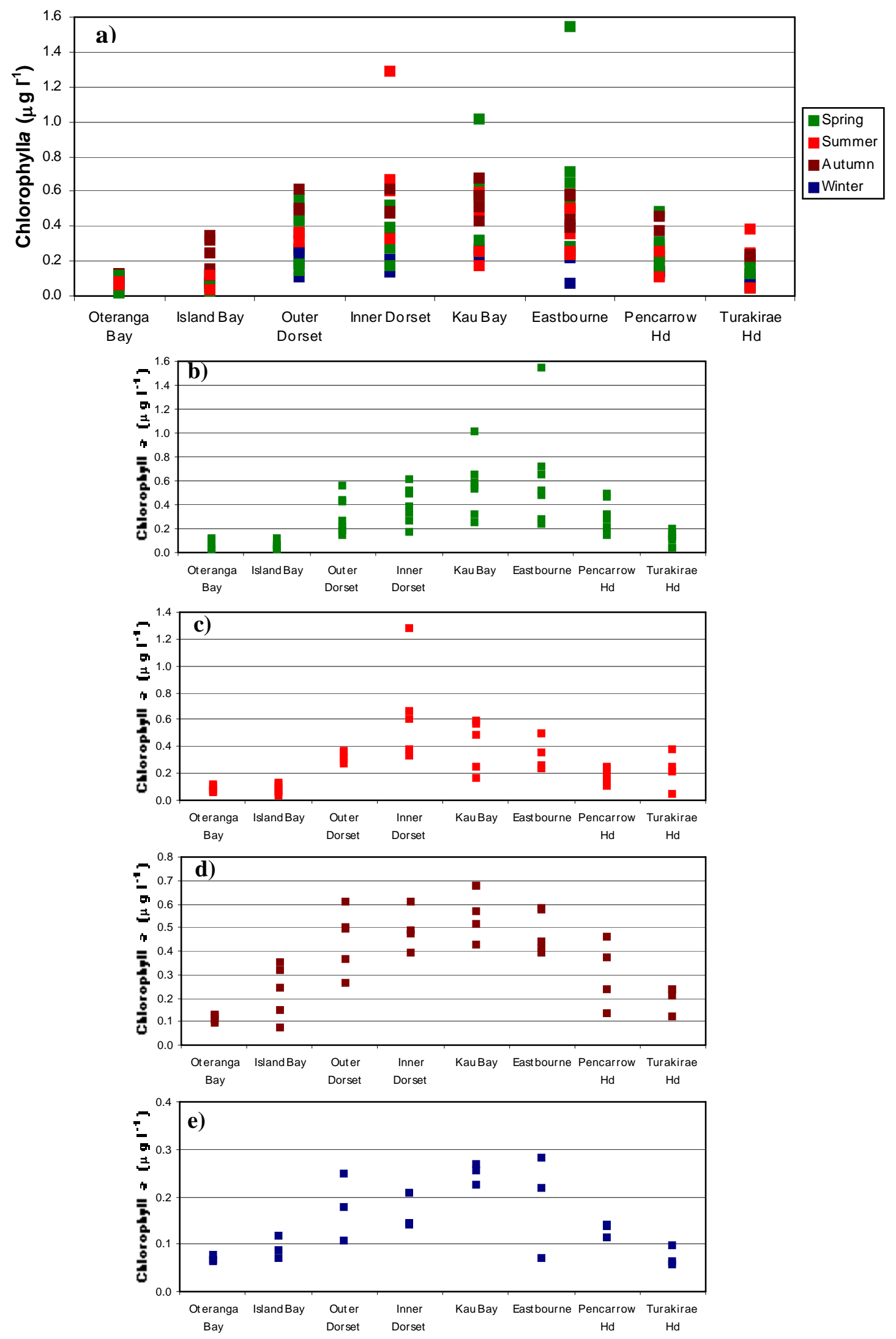

Appendix A7. Chlorophyll $a$ concentration at all sites and seasons: a) all data, b) spring, c) summer, d) autumn, e) winter. 


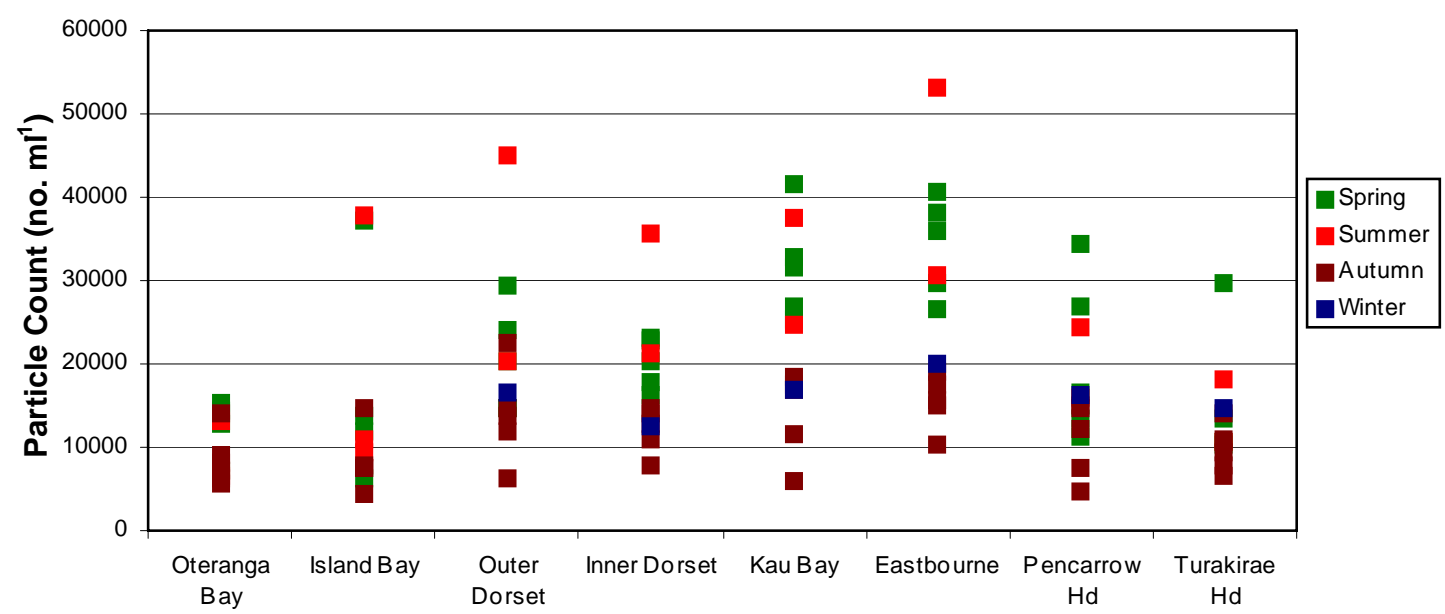

Appendix A8. Particle count $\left(2.5-63.0 \mu \mathrm{m} \mathrm{ml}^{-1}\right)$ at all sites and seasons. 

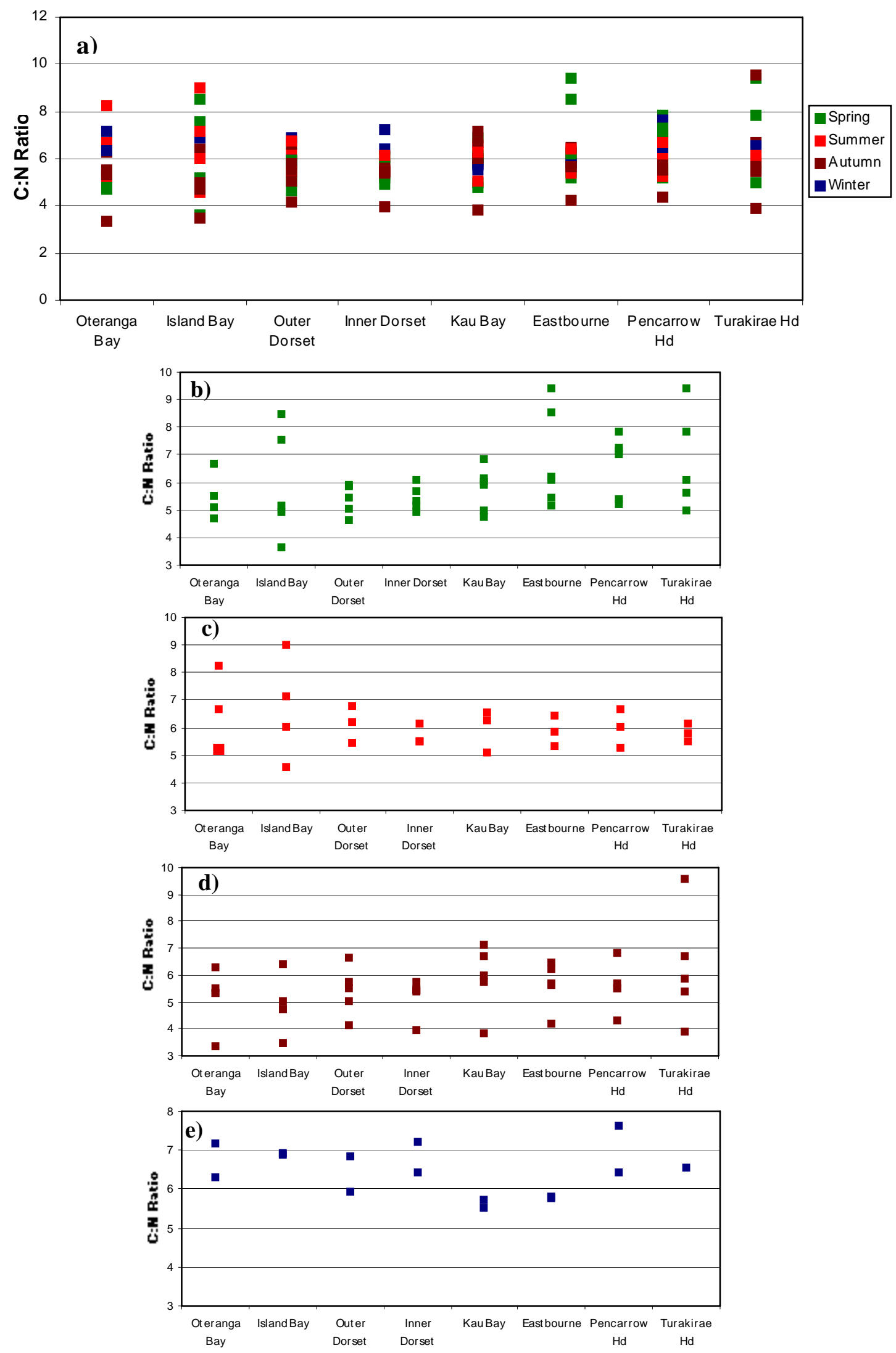

Appendix A9. C:N ratio at all sites and seasons: a) all data, b) spring, c) summer, d) autumn, e) winter. 

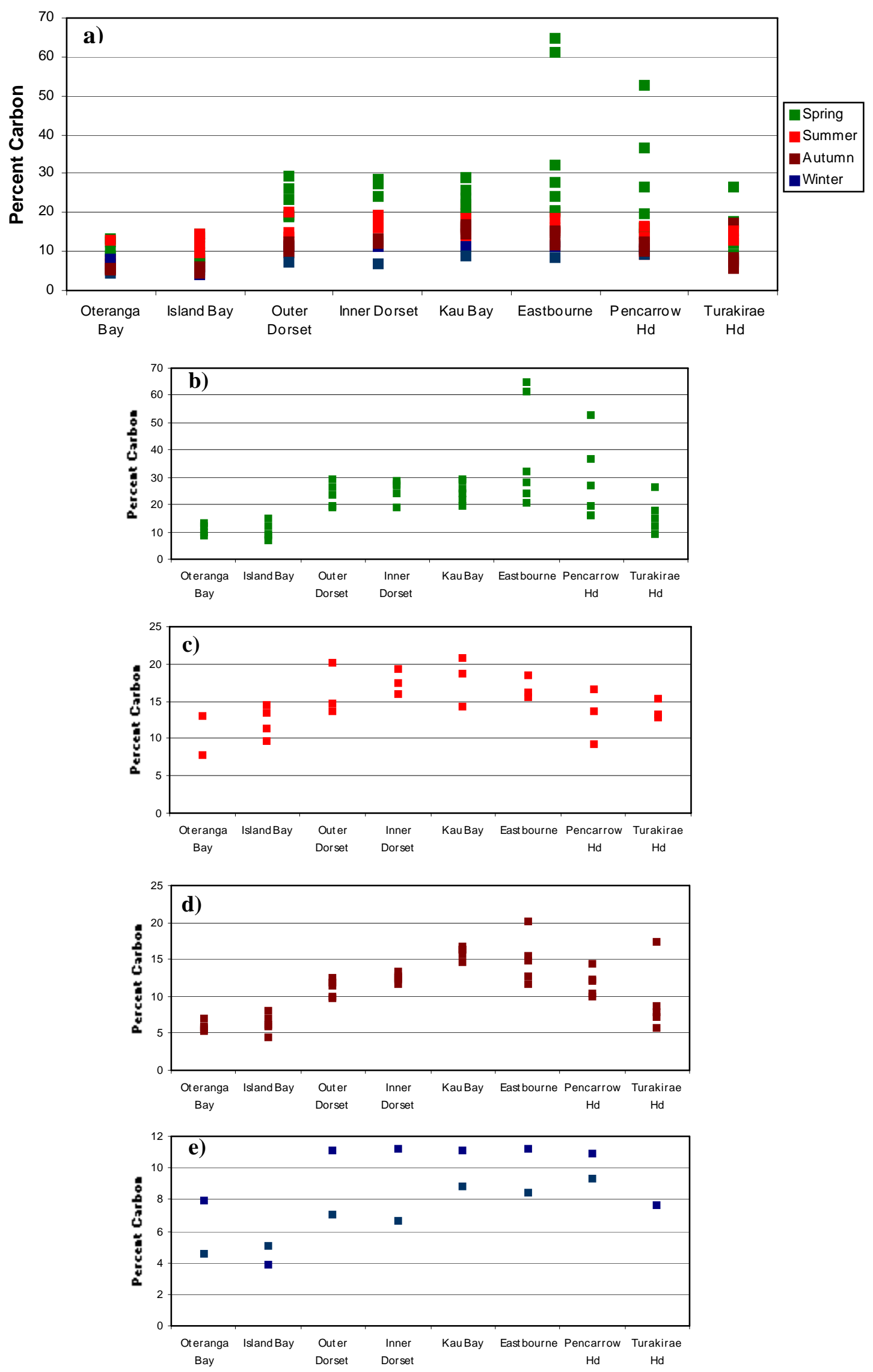

Appendix A10. Percent Carbon at all sites and seasons: a) all data, b) spring, c) summer, d) autumn, e) winter. 

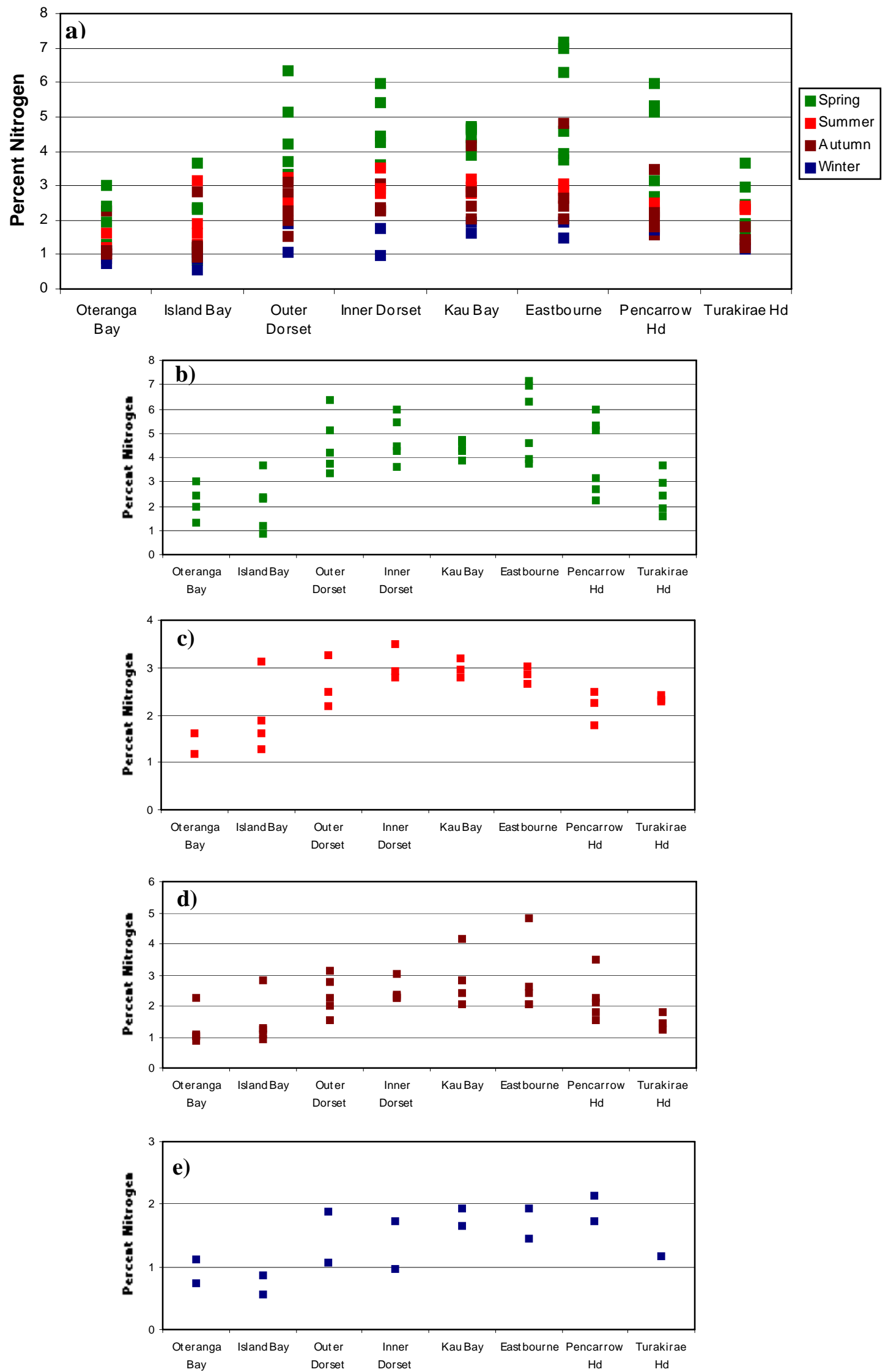

Appendix A11. Percent Nitrogen at all sites and seasons: a) all data, b) spring, c) summer, d) autumn, e) winter. 

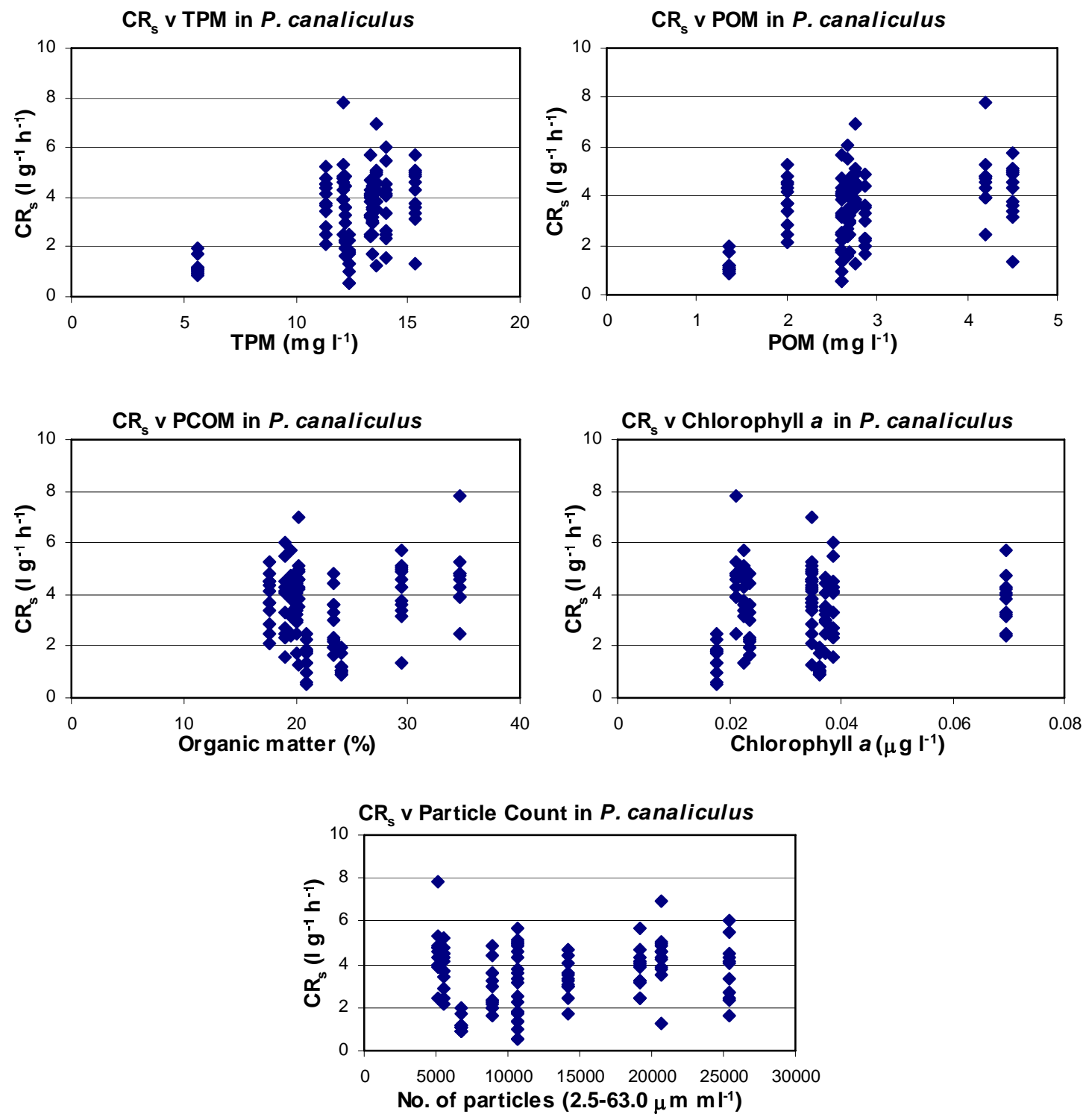

Appendix B1. Relationship between clearance rate (standardised to one gram dry tissue weight) $\left(\mathrm{CR}_{\mathrm{s}}\right)$ and seston characteristics from feeding experiments conducted at IBML for $P$. canaliculus. 

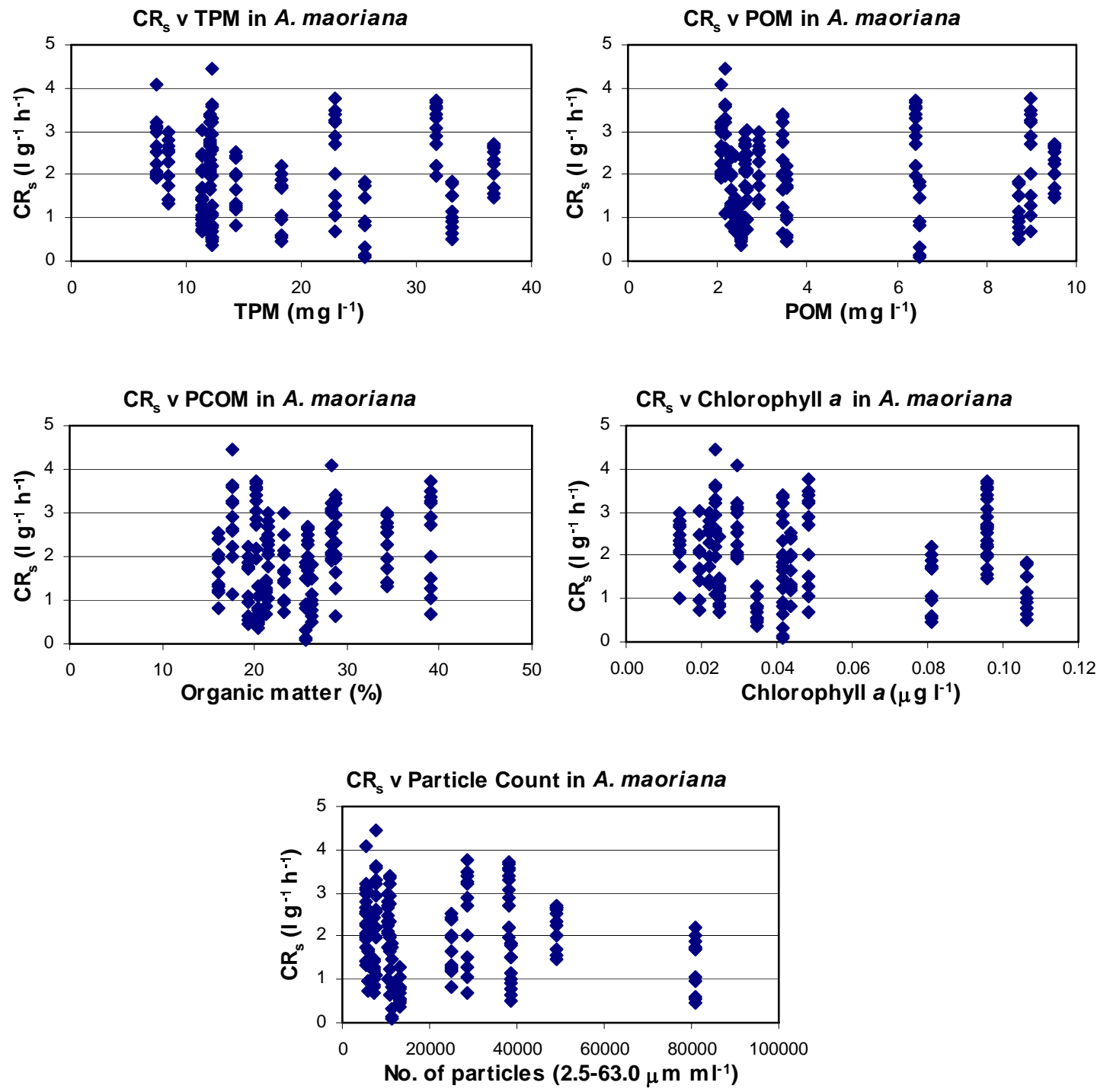

Appendix B2. Relationship between clearance rate (standardised to one gram dry tissue weight) $\left(\mathrm{CR}_{\mathrm{s}}\right)$ and seston characteristics from feeding experiments conducted at IBML for A. maoriana. 

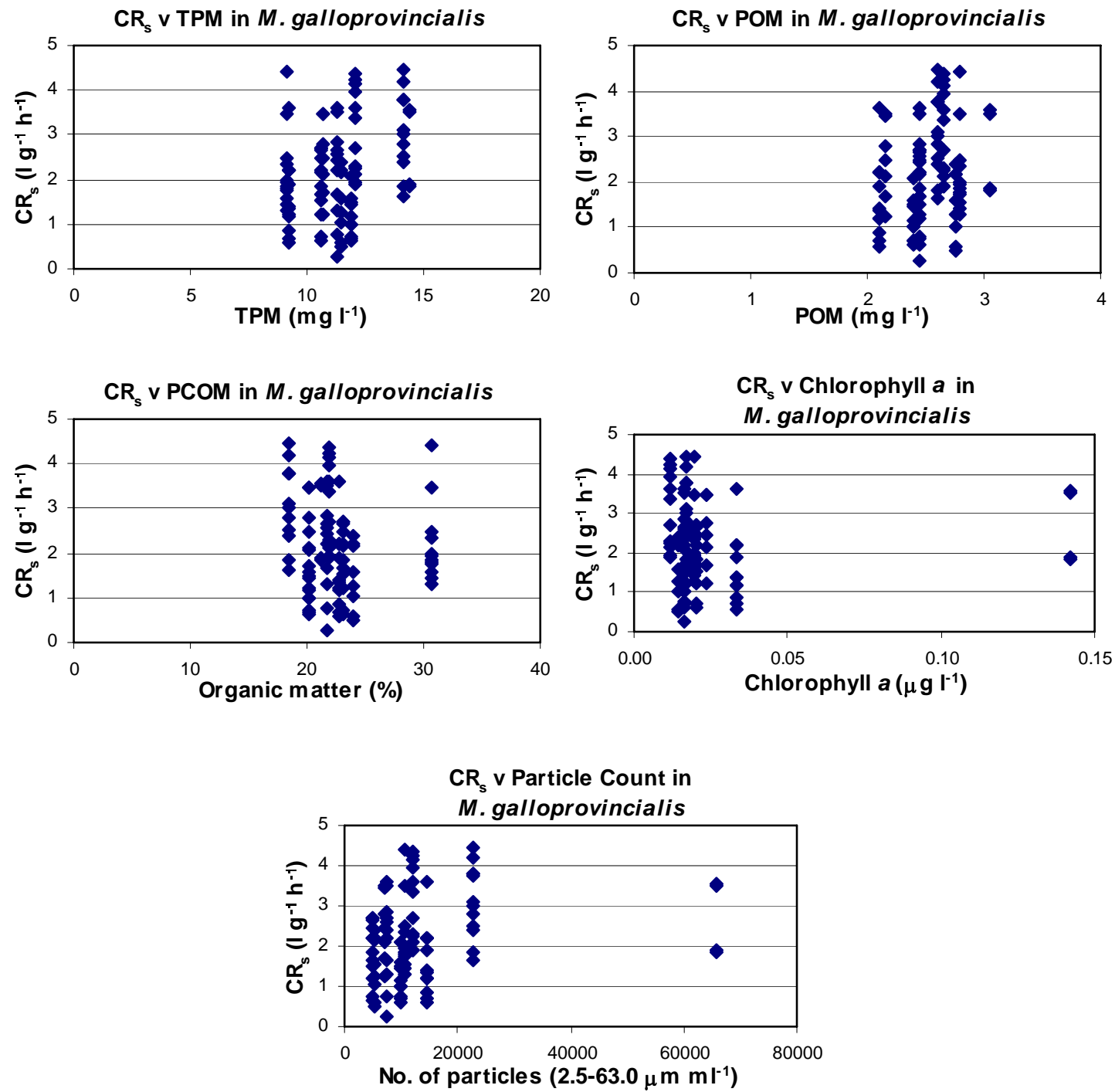

Appendix B3. Relationship between clearance rate (standardised to one gram dry tissue weight) $\left(\mathrm{CR}_{s}\right)$ and seston characteristics from feeding experiments conducted at IBML for M. galloprovincialis. 


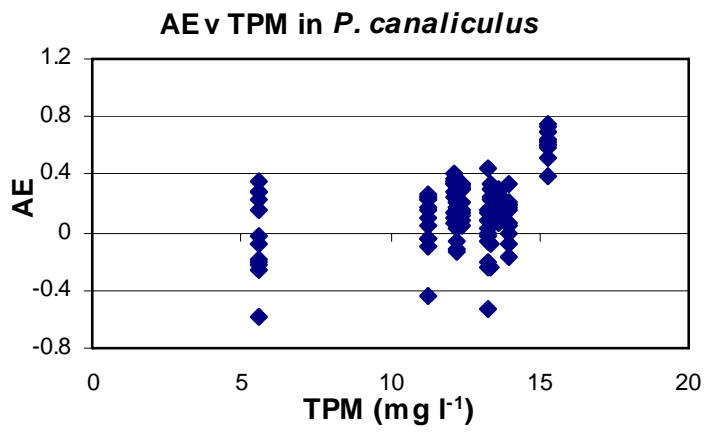

AEv PCOM in P. canaliculus

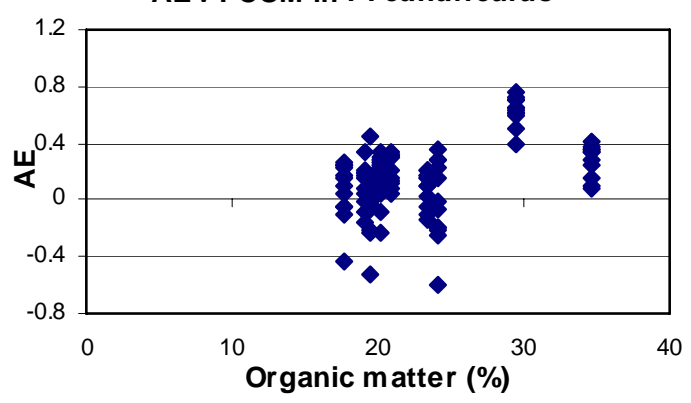

AEv Particle Count in $P$. canaliculus

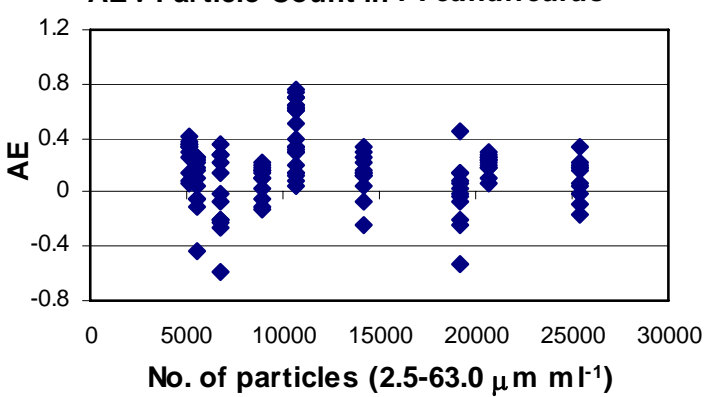

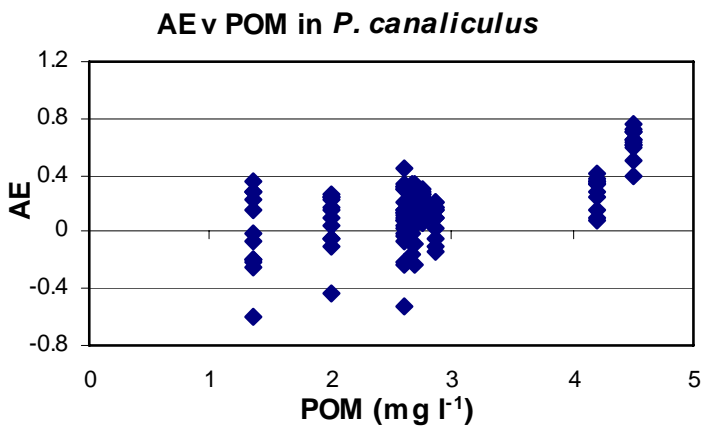

AEv Chorophyll a in P. canaliculus

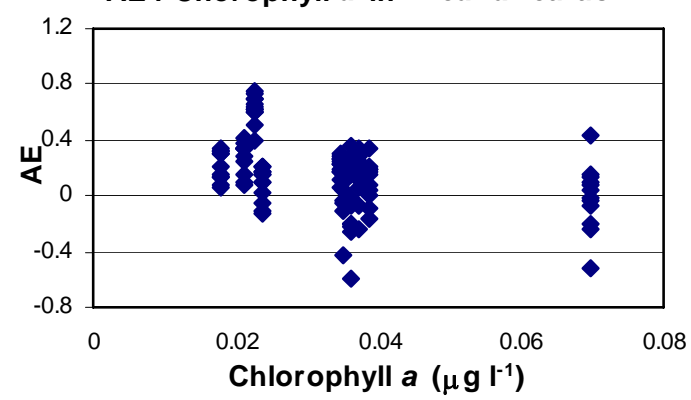

AE v Dry Weight in P. canaliculus

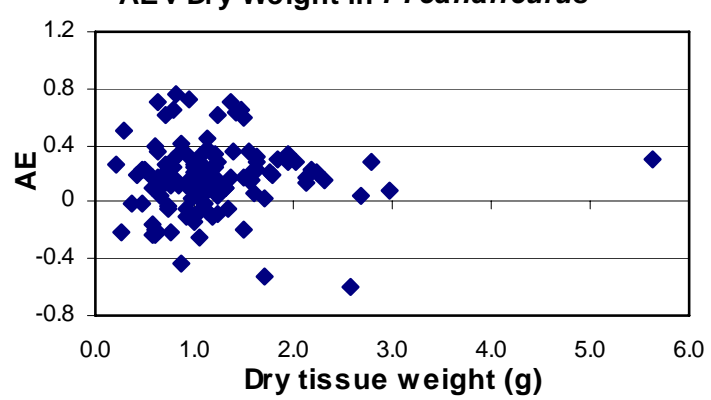

Appendix B4. Relationship between absorption efficiency (AE) and seston characteristics from feeding experiments conducted at IBML for $P$. canaliculus. 

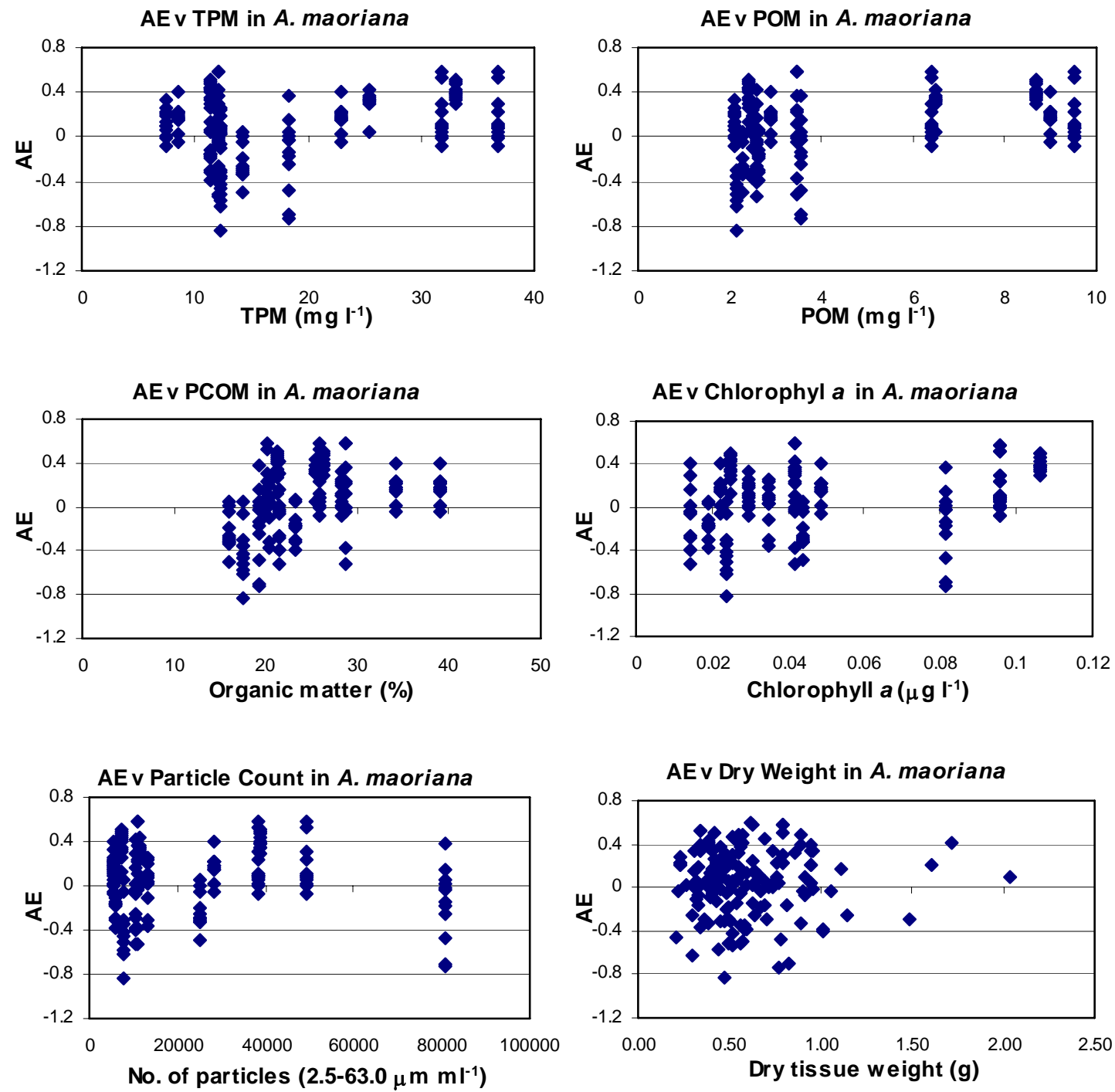

Appendix B5. Relationship between absorption efficiency (AE) and seston characteristics from feeding experiments conducted at IBML for A. maoriana. 

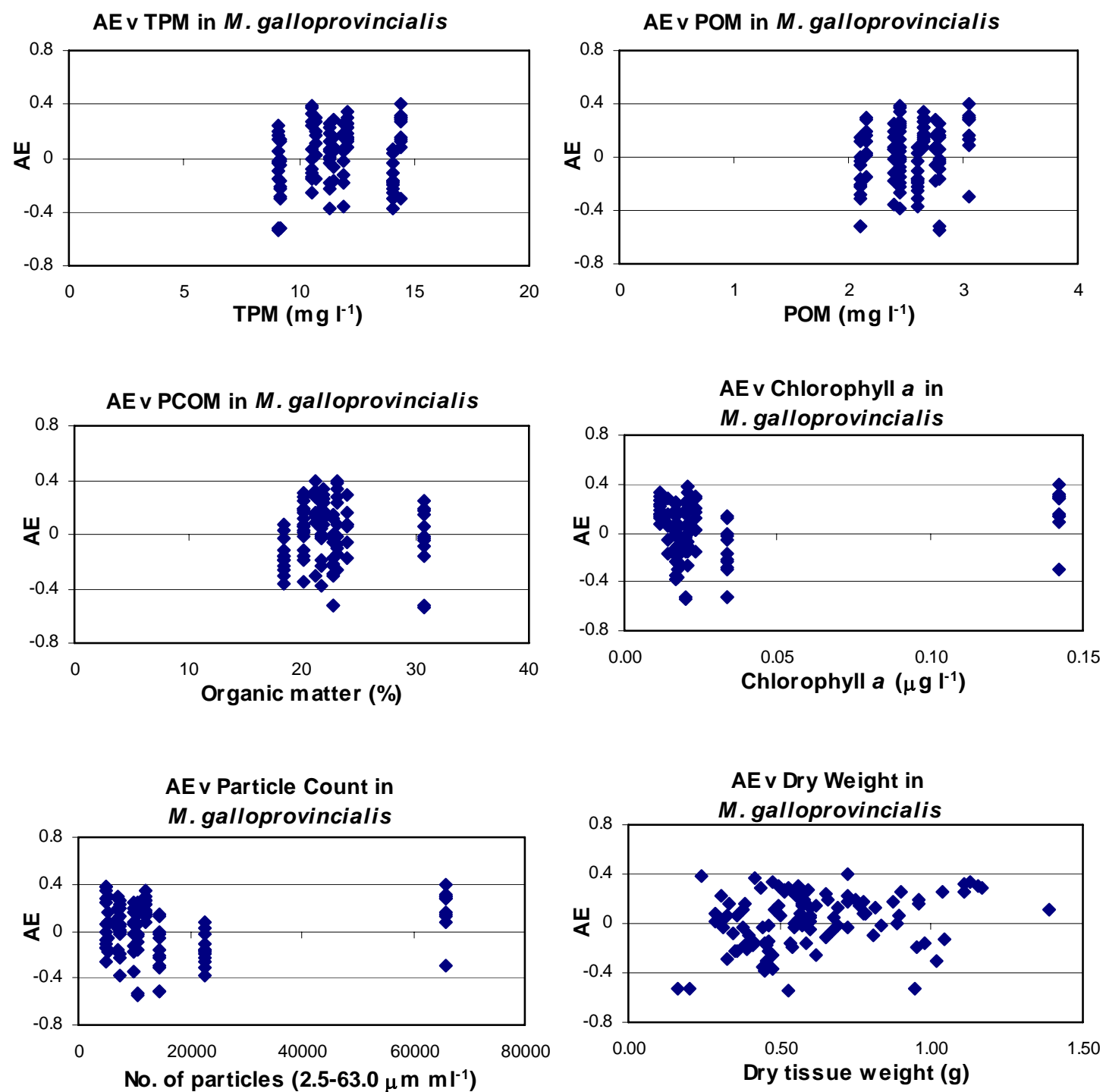

Appendix B6. Relationship between absorption efficiency (AE) and seston characteristics from feeding experiments conducted at IBML for M. galloprovincialis. 

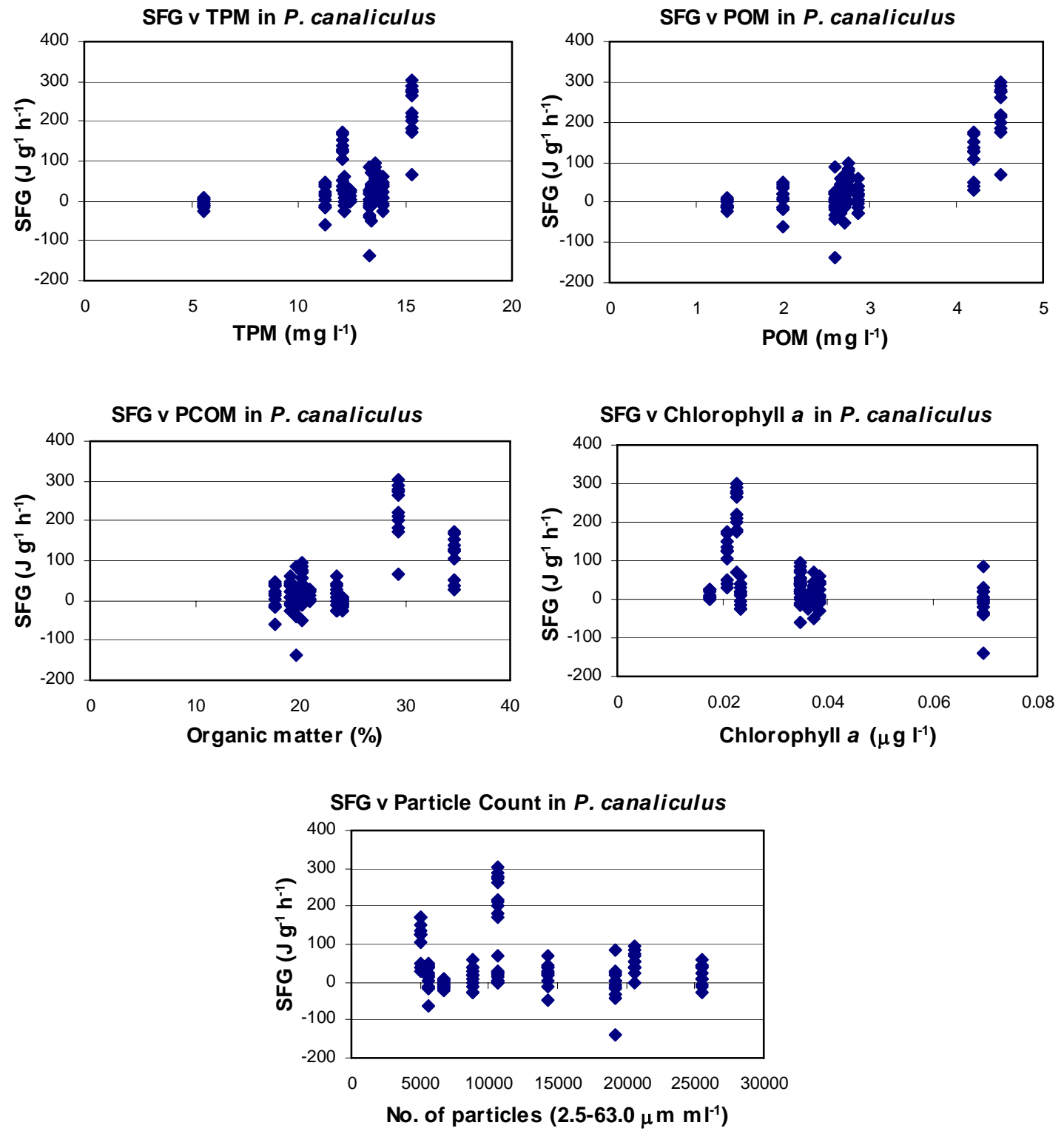

Appendix B7. Relationship between scope for growth (SFG) and seston characteristics from feeding experiments conducted at IBML for $P$. canaliculus. 

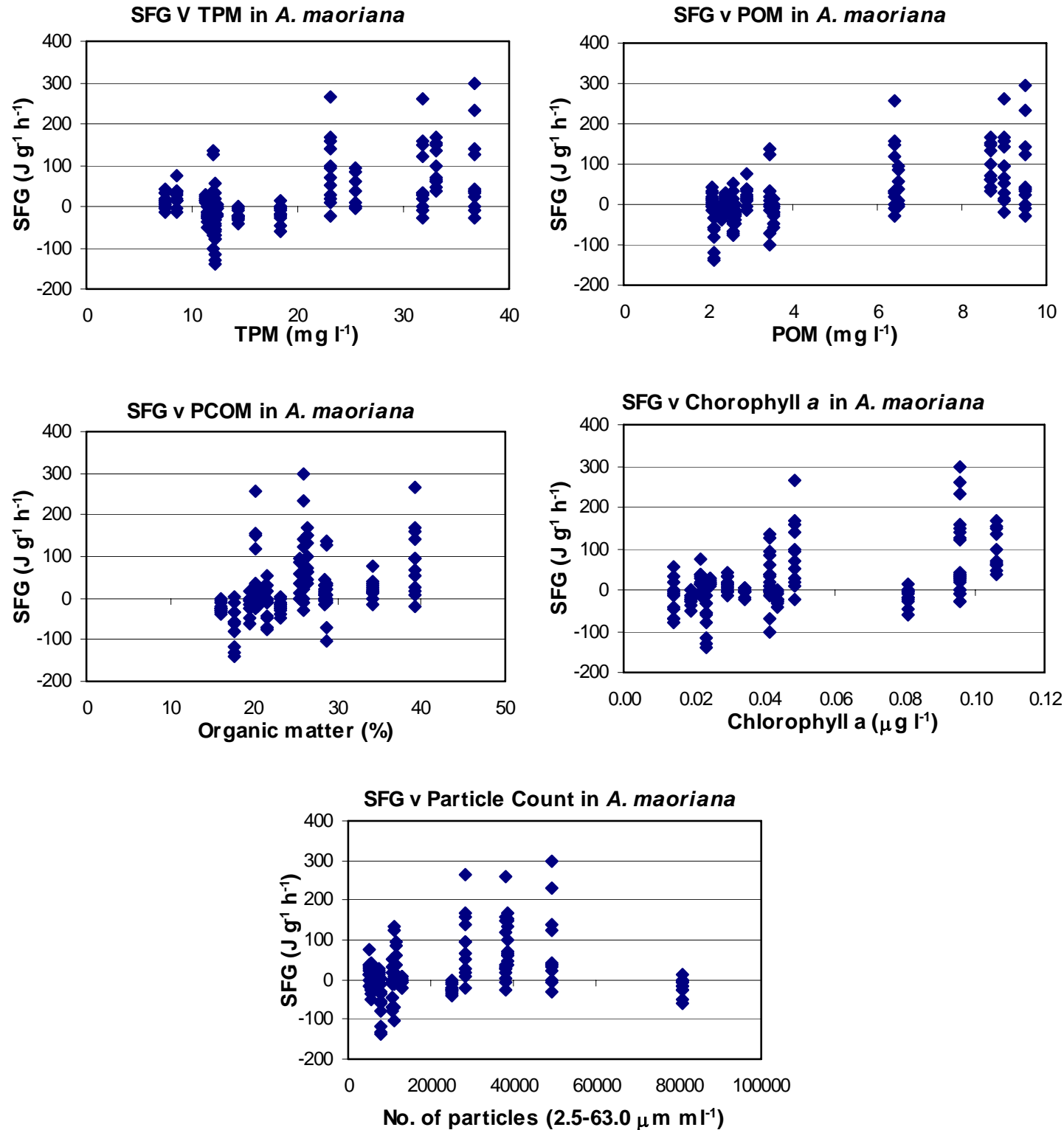

Appendix B8. Relationship between scope for growth (SFG) and seston characteristics from feeding experiments conducted at IBML for A. maoriana. 

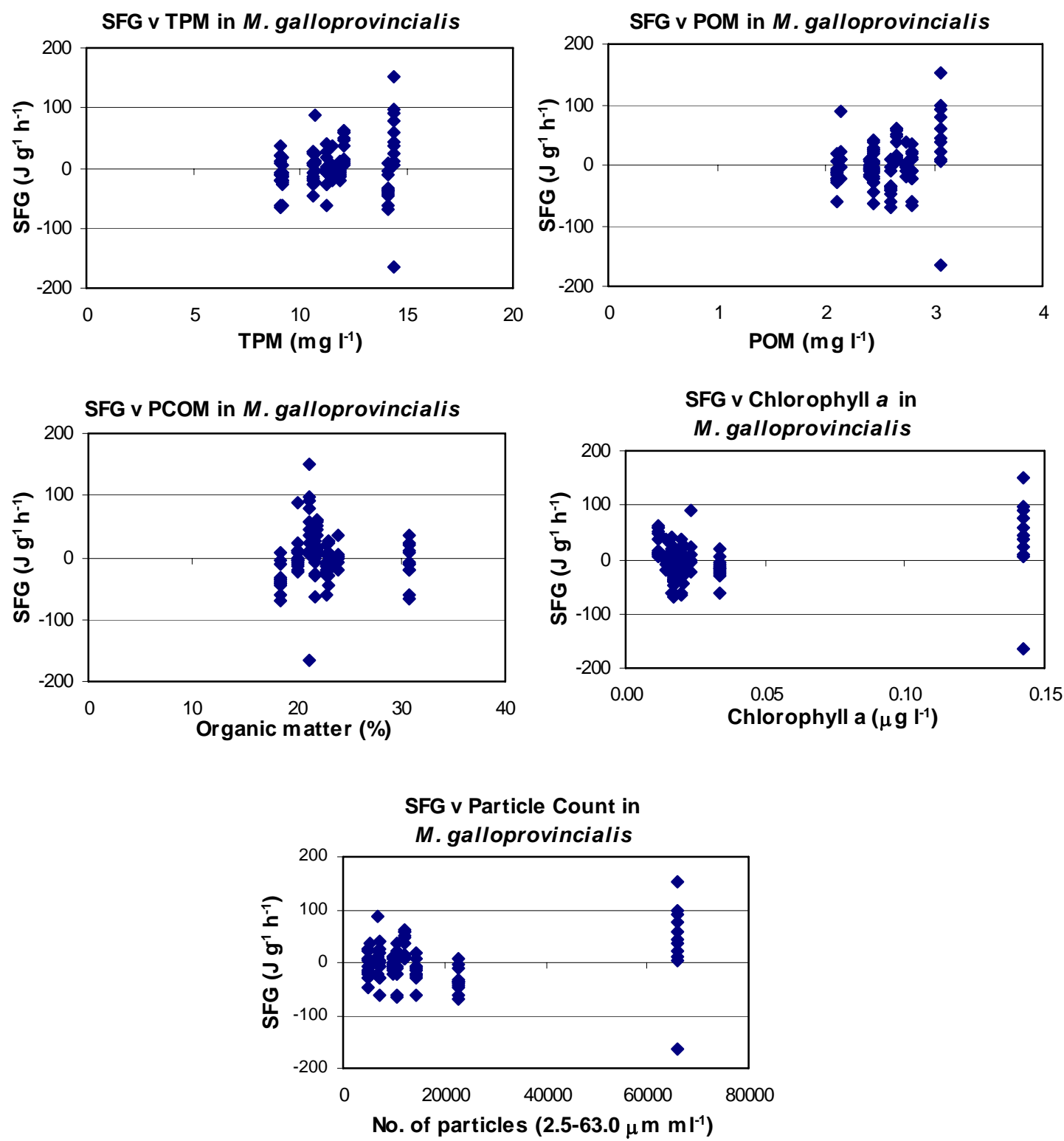

Appendix B9. Relationship between scope for growth (SFG) and seston characteristics from feeding experiments conducted at IBML for M. galloprovincialis. 